MARIA DE LIMA SALUM E MORAIS

\title{
CONFLITOS E(M) BRINCADEIRAS INFANTIS: DIFERENÇAS CULTURAIS E DE GÊNERO
}

Tese apresentada ao Instituto de Psicologia da Universidade de São Paulo como parte dos requisitos para obtenção do título de Doutor em Psicologia.

Área de concentração: Psicologia Experimental.

Orientadora: Profa. Dra. Emma Otta

São Paulo

2004 
Ficha Catalográfica preparada pelo Serviço de Biblioteca e Documentação do Instituto de Psicologia da USP

Morais, M. L. S. e

Conflitos e $(\mathrm{m})$ brincadeiras infantis: diferenças culturais e de gênero./ Maria de Lima Salum e Morais. - São Paulo: s.n., 2004. - 247p.

Tese (doutorado) - Instituto de Psicologia da Universidade de São Paulo. Departamento de Psicologia Experimental.

Orientadora: Emma Otta.

1. Brincadeira 2. Conflito infantil 3. Zombaria 4. Interação social 5. Diferenças interculturais 6. Diferenças de gênero I. Título. 


\section{CONFLITOS E(M) BRINCADEIRAS INFANTIS: DIFERENÇAS CULTURAIS E DE GÊNERO}

MARIA DE LIMA SALUM E MORAIS

BANCA EXAMINADORA

Nome e assinatura

(Nome e assinatura)

(Nome e assinatura)

(Nome e assinatura)

(Nome e assinatura)

(Nome e assinatura)

Tese defendida e aprovada em: 
À memória de meus amados pais, José e Theo, modelos para minha vida. 


\section{Agradecimentos}

À Profa. Dra. Emma Otta, orientadora desta tese e amiga de sempre, por ter-me incentivado a voltar a estudar, a publicar e a participar de eventos científicos. Por sua generosidade e por ter estado junto comigo em todos os momentos do trabalho, sempre pronta a me auxiliar. Com sua visão crítica e perspicaz e seu vasto conhecimento de psicologia científica e de etologia, conduziu a orientação com segurança, mas com excepcional leveza e total respeito por minhas idéias.

À Profa. Dra. Vera Silvia Raad Bussab, pela amizade, carinho, incentivo e apoio constantes. Pelas importantes contribuições, trocas de idéias e pelos bons e divertidos momentos por que passamos juntas nos intervalos do trabalho.

À Profa. Dra. Ana Maria Almeida Carvalho, orientadora de minha dissertação de mestrado, pelo incentivo e pela demonstração continuada de confiança em meu trabalho.

Ao Prof. Dr. César Ades, por ter orientado meus passos iniciais dentro do tema que aqui desenvolvo.

Ao Prof. Dr. Fernando Leite Ribeiro, que me apresentou os encantos do campo da etologia, pelo apoio na etapa final de meus estudos de doutorado.

À Profa. Dra. Maria Lucia Stefanini e ao Prof. Paulo Roberto do Nascimento, do Instituto de Saúde da Secretaria de Saúde do Estado de São Paulo, pela compreensão, consideração e incentivo e aos colegas do Instituto de Saúde, pelo interesse e carinho demonstrados na fase de finalização da tese.

À Profa. Dra. Maria Lucia Seidl de Moura, cujo trabalho me fez ver que eu estava trilhando um "bom caminho". Com seu grande conhecimento na área de psicologia do desenvolvimento, deu importantes contribuições para o projeto desta pesquisa.

À Profa. Dra. Maria Margarida Pereira Rodrigues - companheira desde os tempos de mestrado - e à Profa. Dra. Eva Maria Migliavacca - que promoveu meu reencontro com a Profa. Emma -, pelo apreço e pela atenção dispensada a este trabalho.

À Profa. Dra. Elza Corrêa Granja, pela contribuição na discussão do estudo, quando ainda estava em fase embrionária, pela leitura atenta do projeto de pesquisa e preciosos comentários quando foi submetido a avaliação no exame de qualificação.

A João Carlos Otta, que esteve comigo em vários momentos do trabalho. Por sua ajuda e companhia amiga na coleta de dados das crianças de Ubatuba, pelas filmagens, longas e 
dedicadas edições de vídeo e por grande parte das fotos reproduzidas na tese. Por estar presente nas discussões dos dados e em todos os eventos em que partes do trabalho foram apresentadas.

A Cristina Lee, pela solidariedade e afeição demonstradas no decorrer dos estudos do programa de doutorado e durante a coleta de dados na creche de São Paulo. Pela ajuda na discussão das categorias empregadas nesta tese e por ter cedido fotos que a ilustram.

A Yumi Gosso, que foi tão longe pesquisar as brincadeiras dos índios Parakanã, pelos esclarecimentos que seu estudo possibilitou e por sua companhia em diversos trabalhos publicados e divulgados em congressos científicos.

A Gisele Zago, por sua importante ajuda na categorização e análise de dados e a todos os colegas do grupo de estudos coordenado pelas professoras Emma Otta e Vera Silvia Raad Bussab, que me acompanharam em leituras teóricas e na elaboração do instrumental empregado na pesquisa.

A Elisabete Lopes e Luciano Tomé, pela ajuda na fase de coleta de dados na creche de São Paulo e nas discussões preliminares do estudo.

Ao CNPq, pelo auxílio que possibilitou minha dedicação à realização da tese.

À minha querida irmã Onélia, pelos ensinamentos da língua portuguesa, pela afeição e pelo apoio nos momentos difíceis por que passei até concluir a tese.

Ao Inácio, companheiro de todas as horas, sempre a meu lado nas batalhas da vida e aos amados filhos, Pedro e Guilherme, pela presença carinhosa e estimulante. Aos três, por preencherem minha vida e darem sentido ao meu trabalho.

A todos aqueles, colegas, parentes e amigos, cujos nomes eu possa estar omitindo e que me acompanharam no percurso que culminou nesta tese.

Finalmente e em especial, às crianças que protagonizaram o trabalho - para mim tão familiares e queridas -, a seus pais, por terem permitido sua participação na pesquisa e às educadoras, por me abrirem as portas de suas instituições e por terem- me dado todas as condições de trabalho. Particularmente, a Rozemara P. M. Cabral de Oliveira, diretora da E.M. Prof. Honor Figueira, em Ubatuba, por sua solicitude e pelo calor humano com que nos acolheu na escola. 


\section{SUMÁRIO}

LISTA DE FIGURAS

LISTA DE TABELAS

RESUMO.

ABSTRACT.

\section{CONTEXTUALIZANDO O TRABALHO}

1.1.Um pouco de história

1.2. Perspectivas de análise e plano do trabalho

\section{APRENDENDO E FAZENDO CULTURA}

2.2. Cultura e estudos interculturais

2.2. Diferenças culturais conforme caracterização do self, relações interpessoais, dimensão temporal e tipo de produção social.

2.2.1. Estilos de criação e caminhos de socialização.

2.2.2. Dimensão simples-complexo

2.2.3. Dimensão temporal.

2.3. Diferenças de gênero

2.4. Síntese

2.5. Caracterização dos grupos culturais estudados

2.5.1. Cultura caiçara da região de Ubatuba

2.5.2. Grupo observado no município de São Paulo

\section{3. É PRECISO BRINCAR}

3.1. Conceituação do brincar.

3.2. Significado funcional da brincadeira

3.3. Classificação das brincadeiras

3.4. Brincadeiras de contingência social

3.5. Diferenças culturais e de gênero nas brincadeiras

3.6. Síntese

\section{O JOGO SOCIAL: INTERAÇÕES, CONFLITOS E ZOMBARIA}

4.1. O contexto interacional

4.2. Cooperação e competição.

4.3. Conflitos.

4.3.1. Conceituação

4.3.2. Funções dos conflitos

4.3.3. Fatores que influenciam diferentes freqüências e soluções de conflitos

4.3.4. Classificação dos conflitos 
4.3.5. Diferenças culturais e de gênero

4.4. Zombaria.

4.5. Síntese

\section{OBJETIVOS DO ESTUDO E HIPÓTESES INICIAIS}

5.1. Objetivos

5.2. Hipóteses iniciais

\section{MÉTODO.}

\subsection{Participantes}

6.1.1. Considerações a respeito das principais características da fase de desenvolvimento das crianças estudadas e dos contextos de observação

6.1.2. Caracterização dos grupos estudados.

6.2. Locais de observação

6.3. Procedimento de coleta.

6.4. Análise de dados.

6.4.1. Tamanho e composição do grupo.

6.4.2. Classificação das brincadeiras segundo o caráter predominante da ação

6.4.3. Categorização detalhada das brincadeiras de contingência social e provocações

6.4.4. Categorização das brincadeiras segundo a forma de interação.......

6.4.5. Conflitos: definições e classificação.

6.4.5.1. Motivos aparentes

6.4.5.2. Estratégias de oposição.

6.4.5.3. Respostas à oposição

6.4.5.4. Desenlace ou desfecho

6.4.5.5. Outras medidas de conflito.

\section{APRESENTANDO OS GRUPOS E AS BRINCADEIRAS}

7.1. Tamanho e composição do grupo.

7.1.1. Tamanho do grupo, segundo origem e gênero

7.1.2. Composição do grupo, segundo origem e gênero

7.1.3. Composição em relação ao tamanho do grupo

7.1.4. Síntese.

7.2. Participação em brincadeira

7.2.1. Tipos de interação durante a brincadeira

7.2.2. Participação nas diversas modalidades de brincadeira, conforme gênero e grupo cultural.

7.2.2.1. Brincadeiras das crianças de São Paulo e de Ubatuba

7.2.3. Síntese

7.3. Algumas associações entre os índices

7.3.1. Participação nos diversos tipos de brincadeira quanto à

composição do grupo 
7.3.2. Tipos de brincadeira e modalidades de interação

7.3.3. Participação nas diversas modalidades de brincadeira em relação

ao tamanho do grupo

7.3.4. Síntese

7.4. Considerações finais

\section{RELATANDO OS EPISÓDIOS DE ZOMBARIA E OS CONFLITOS ..}

8.1. Provocações e zombaria

8.1.1. Segundo grupo cultural e gênero

8.1.2. Reações à zombaria

8.2. Conflitos

8.2.1. Freqüência de conflitos, segundo gênero e grupo cultural

8.2.2. Número de elos

8.2.3. Elementos dos conflitos

8.2.3.1. Motivos

8.2.3.2. Estratégias de oposição

8.2.3.3. Respostas à oposição.

8.2.3.4. Desenlaces 8.2.3.5. Alianças

8.3. Síntese

8.4. Relação entre componentes dos conflitos

8.4.1. Estratégias preditivas de ameaça e agressão aparentemente injustificada

8.4.2. Relações entre motivos e desenlaces

8.5. Conflitos e sexo do parceiro

8.5.1. Sexo do parceiro e componentes de conflitos

8.6. Tamanho do grupo e conflitos

8.7. Considerações finais

9. CONCLUSÕES

ANEXOS

A. Relação das crianças que participaram da pesquisa

B. Exemplos de protocolos

REFERÊNCIAS BIBLIOGRÁFICAS 


\section{LISTA DE FIGURAS}

\section{Figura n.}

2.1. Vista da mata, costão e pequena praia de Ubatuba.

3.1. Ilustrações de riscos nas brincadeiras

3.2. Ilustrações dos diversos tipos de brincadeira

6.1. Vista aérea de parte do município de Ubatuba onde se situa a Praia de Itamambuca

6.2. Vista do pátio de areia da escola da praia, confrontando, ao fundo, com o campo de futebol..

6.3. Vista do pátio da creche de São Paulo.

7.1. Grupos de brincadeira em Ubatuba e em São Paulo.

7.2. Proporções dos diferentes tamanhos de grupo, segundo origem e gênero.

7.3. Proporções de grupos mistos e do mesmo sexo, segundo origem e gênero.

7.4. Frequiências relativas ao tempo de díades, tríades e políades mistas, conforme origem e gênero.

7.5. Distribuição dos tipos interação em brincadeira nas crianças dos dois grupos culturais.

7.6. Menina paulistana observa grupo em brincadeira interativa.

7.7. Distribuição da participação nos diversos tipos de brincadeira em meninos e meninas de São Paulo e de Ubatuba.

7.8. Médias de tempo gasto nos tipos de brincadeira em que houve diferenças estatisticamente significativas entre os grupos culturais......

7.9. Médias de tempo gasto nas brincadeiras de contingência física e social, conforme gênero.

7.10. Meninas em brincadeiras de exercício físico

7.11. Brincadeiras de contingência social proximal.

7.12. Brincadeiras de contingência social proximal das meninas ubatubanas

7.13. Tipos de brincadeira de contingência social que diferiram significativamente entre os grupos culturais.

7.14. Tipos de brincadeira de contingência social que diferiram significativamente entre os gêneros.

7.15. Jogo de futebol dos meninos ubatubanos

7.16. Médias de episódios de exibição de desafio físico em relação ao tempo total de observação, segundo origem e gênero.

7.17. Meninos brincando em São Paulo.

7.18. Brincadeira de "cabo-de-guerra" das crianças ubatubanas.

8.1. Freqüência média relativa ao tempo das duas formas de zombaria verbal e não verbal -, segundo grupo cultural e gênero

8.2. Ilustrações de episódios de zombaria

8.3. Reações à zombaria segundo origem e gênero.

8.4. Freqüência relativa dos conflitos conforme origem e gênero

8.5. Razão elos/conflitos segundo origem e gênero.

8.6. Distribuição dos motivos nos dois gêneros e grupos culturais.

8.7. Proporções de estratégias de oposição coercitivas e afiliativas 
por gênero e grupo cultural.

8.8. Estratégias de oposição por gênero e grupo cultural.

8.9. Meninos paulistanos empurrando suas colegas

8.10. Proporções de respostas à oposição, segundo gênero e origem

8.11.Distribuição das reações à oposição conforme grupo cultural e gênero.

8.12.Proporções de reações à oposição em que houve diferenças estatisticamente significativas....

8.13. Distribuição dos desenlaces conforme origem e gênero.

8.14. Proporção de alianças sobre total de conflitos, em função de grupo cultural e gênero.

8.15. Proporções de alianças com o alvo e com o agente em relação ao total de alianças nos dois grupos culturais e gêneros

8.16. Conflitos conforme sexo do parceiro.

8.17. Proporções de conflitos em díades, tríades e políades

8.18. Menina ubatubana usando tática pesada com a colega

9.1. Menino ubatubano sorrindo

Observação: As fotos que permitiam a identificação das crianças foram retiradas na versão PDF para a internet. 


\section{LISTA DE TABELAS}

\section{Tabela n.}

2.1.Comparação entre características e condições de vida dos municípios de São Paulo e de Ubatuba

6.1. Ocupação dos pais das crianças da creche de São Paulo.

7.1. Brincadeiras observadas nos dois grupos culturais.

7.2. Média e erro padrão de conteúdos de faz-de-conta de acordo com o grupo cultural e gênero.

7.3. Proporção média da participação em grupos de mesmo sexo e mistos em relação à participação total nos diversos tipos de brincadeira

7.4. Comparações dois a dois dos diversos tipos de brincadeira em grupos mistos e de um só sexo conforme origem e gênero.

7.5. Tipos de brincadeiras preditivas de modalidades de interação

7.6. Brincadeiras preditivas dos diversos tamanhos de grupo, segundo gênero e origem.

8.1. Estratégias de oposição positivamente preditivas de conflitos iniciados por ameaça ou agressão aparentemente injustificadas

8.2. Correlações entre motivos e desenlaces de conflitos conforme grupo cultural e gênero.

8.3. Componentes de conflito (motivos, estratégias de oposição, reação à oposição e desenlaces) positivamente preditivos de conflitos com parceiros do mesmo sexo.

8.4.Componentes de conflito (motivos, estratégias de oposição, reação à oposição e desenlaces) positivamente preditivos de conflitos com parceiros do sexo oposto. 


\section{RESUMO}

MORAIS, Maria de Lima Salum e. Conflitos e $(m)$ brincadeiras infantis: Diferenças culturais $e$ de gênero. São Paulo, 2004. 247 p. Tese (doutorado). Instituto de Psicologia, Universidade de São Paulo.

O principal objetivo do trabalho foi comparar brincadeiras, conflitos e provocações de meninos e meninas de quatro a cinco anos de idade, pertencentes a dois grupos culturais: um de uma grande metrópole (São Paulo) e outro de uma pequena comunidade praiana no litoral norte de Estado de São Paulo (Ubatuba). As crianças foram observadas em atividade livre no pátio escolar. Em relação ao brincar, os principais resultados encontrados foram: as crianças de São Paulo se envolveram mais em brincadeiras simbólicas do que as ubatubanas e essas, mais em jogos de regras e em brincadeiras de contingência social do que as paulistanas; os meninos participaram mais de brincadeiras de contingência física do que as meninas e elas se envolveram mais em atividades de contingência social do que seus colegas. Predominaram as provocações de caráter não verbal entre as crianças ubatubanas. Os episódios de zombaria tenderam a ter consequiências interacionais positivas em ambos os grupos, apesar de terem gerado também algumas reações negativas. As crianças de ambos os grupos apresentaram número equivalente de episódios de conflito, embora sua duração tenha sido maior entre as meninas de São Paulo. A principal causa de conflitos nos dois grupos culturais foi a disputa por brinquedos e a maior parte dos desenlaces teve caráter afiliativo. As crianças ubatubanas apresentaram táticas mais simples e diretas e as paulistanas, estratégias mais diversificadas e verbais de enfrentamento das situações conflituosas. Na discussão dos resultados, destaca-se a importância da configuração dos grupos de brincadeira e de dimensões culturais mais amplas - como estilos de criação e códigos de comunicação -, evidenciando-se a relevância de estudos interculturais para o avanço na compreensão do comportamento infantil. 


\begin{abstract}
MORAIS, Maria de Lima Salum e. Cultural and gender differences in children's play and conflicts. São Paulo, 2004. 247 p. Doctoral thesis. Instituto de Psicologia, Universidade de São Paulo.
\end{abstract}

The major goal of the study was to compare play, conflicts and teasing in four to fiveyears-old children of two cultural groups: one from a big city (São Paulo), and another from a small seashore community (Ubatuba, São Paulo State). Children were observed in free play periods at school yard. The main findings concerning play were: São Paulo’s children engaged in more pretend play than seashore's children, and these ones showed greater participation in games with rules and in social contingency play; boys engaged in more physical contingency activities than girls, while girls participated in more social contingency play than their male peers. Non-verbal teasing prevailed in seashore children, and teasing episodes had more frequent positive interational outcomes, although negative consequences were also found in the two groups. Children from both cultural groups presented equivalent number of conflicts and engaged in more same-sex disagreements, but the number of conflict turns was greater among São Paulo's girls. Possession of objects and toys was the main conflict reason. Seashore children presented more simple and direct conflict strategies, and São Paulo's children, more diversified and verbal tactics of conflict management. Contend resolutions had a predominantly affiliative character in both groups. In the discussion of data, play group configuration, as well as broader cultural dimensions - such as rearing styles and communication codes -, are emphasized, showing the importance of cross-cultural studies for advances in understanding childhood behavior. 


\section{CONTEXTUALIZANDO O TRABALHO}

Uma tese não se insere aleatoriamente na vida de quem a produz. Uma série de acontecimentos conduz o pesquisador à escolha do tema, à metodologia empregada e às conclusões a que chega. Neste capítulo introdutório, proponho-me a apresentar um pouco de minha trajetória na busca pelo conhecimento e situar o trabalho dentro da perspectiva teórica e metodológica que o norteou.

\subsection{Um pouco de história}

Embora esta tese tenha sido construída num período avançado de minha existência, seria muito pretensioso afirmar que constitui um trabalho da maturidade, uma vez que o simples passar dos anos não garante o amadurecer do pensamento. Indubitavelmente, contudo, ela reflete um percurso de vida que não se delineou ao acaso.

Nascida em um lar de professores, desde cedo aprendi o valor do conhecimento e da pesquisa. Depois de 18 anos ininterruptos de estudo, que culminaram com a conclusão do curso de Psicologia no Instituto de Psicologia da USP (IPUSP), não foi fácil parar de investir em minha formação. Adotei, como rumo para meus estudos pós-graduados, o campo apresentado pela etologia, cuja abordagem conheci na disciplina que mais me atraiu durante os anos de graduação: Psicologia Comparada e Animal - brilhantemente ministrada pelo Prof. Fernando José Leite Ribeiro com a colaboração da Profa. Ana Maria Almeida Carvalho. A perspectiva de trabalho oferecida pela etologia fascinou-me desde o início. A forma como a disciplina foi conduzida só fez aumentar meu interesse. Meu amor pelos animais e a possibilidade de estudálos cientificamente, observando-os em seu ambiente natural, somaram-se e tornaram fascinantes as leituras dos textos de Lorenz, de Tinbergen e, posteriormente, de Robert Hinde. Passei, então, a cursar o Programa de Mestrado do Departamento de Psicologia Experimental do Instituto de Psicologia daUSP.

$\mathrm{Na}$ ocasião de definir o projeto de trabalho para a redação da dissertação de mestrado, estava profissionalmente inserida numa escola de educação infantil e de $1^{\circ}$. grau e muito interessada no comportamento infantil. Por que não conciliar minha inclinação pelo enfoque 
metodológico da etologia com o estudo do comportamento infantil? Encantava-me observar as crianças em sua atividade predileta: brincar. Logo percebi a janela que abria para o mundo infantil a brincadeira de faz-de-conta, uma das modalidades de comportamento que mais me intrigava. Por que as crianças passavam grande parte de seu tempo tratando objetos como se fossem outros, representando longas cenas imaginárias, assumindo personagens do mundo adulto ou de um mundo fictício? Por que demonstravam enorme envolvimento em episódios de brincadeira, nos quais as coisas e as pessoas assumiam identidades, propriedades e condições tão diferentes das que lhe eram habitualmente atribuídas?

Essas e outras indagações surgiam à medida que transcorriam minhas primeiras observações sistemáticas do comportamento das crianças. Nessa época, a Profa. Ana Maria Almeida Carvalho, uma das pioneiras dos estudos de etologia humana no Brasil, acolheu-me como orientanda no programa de mestrado. Os trabalhos da Profa. Ana sobre a interação social de crianças inspiraram também minha incursão por fenômenos dessa ordem, tais como dominância e submissão, freqüência e variedade de contatos sociais entre os grupos de pares. Dessa forma, concluí minha dissertação de mestrado contemplando, ao mesmo tempo, o intrigante fenômeno da brincadeira de faz-de-conta e a descrição das interações sociais no grupo de coetâneos.

Deixando os estudos acadêmicos, continuei envolvida em trabalhos nas áreas de saúde e de educação de crianças, tanto em instituições privadas voltadas para as classes média alta e alta quanto em entidades públicas, cuja clientela situava-se mais próxima da base da pirâmide social, nas classes baixa e média baixa. Não posso deixar de mencionar as influências que exerceram sobre meu pensar a formação em psicodrama - linha terapêutica tão relacionada com o "comosê" do faz-de-conta - e os cursos e trabalhos na área de Saúde Pública, através dos quais tomei contato com a realidade de vida, de saúde e de educação das crianças da periferia da cidade de São Paulo.

Após concluir meu trabalho na Secretaria Municipal de Saúde do Município de São Paulo, propus-me a assistir ao curso "Mitologia grega e psicanálise: Reflexões”, ministrado pela Profa. Dra. Eva Maria Migliavacca. Poderiam perguntar-me qual a relação entre mitologia grega e os temas que vinha estudando. A resposta está provavelmente no parentesco entre mitos, sonhos, dramas e brincadeiras de faz-de-conta, como produções humanas que representam tentativas de explicação e de elaboração do que é "incompreensível, instigante e perturbador" (Migliavacca, 2004, pág. 38). 
Por uma destas obras felizes do acaso, mas talvez não por coincidência, reencontrei, nessa ocasião, a amiga e colega de mestrado, agora Profa. Dra. Emma Otta, que me incentivou a retomar os estudos acadêmicos ingressando, sob sua orientação, no Programa de Doutorado do Departamento de Psicologia Experimental do IPUSP. Teve, então, início uma fase de renovação em minha trajetória.

O produto da dissertação de mestrado que mais provocou interesse na comunidade acadêmica foi um artigo publicado no Boletim de Psicologia, em co-autoria com a Profa. Dra. Ana Maria Almeida Carvalho, intitulado "Faz-de-conta: temas, papéis e regras na brincadeira de crianças de quatro anos". Nesse trabalho, procuramos evidenciar como se refletiam nas brincadeiras de faz-de-conta a realidade social mais ampla em que as crianças se inseriam e a conjuntura imediata das relações estabelecidas nos grupos de brincadeira. Nas interações entre as crianças, chamava a atenção a preocupação de algumas em exercer o controle das brincadeiras e em ocupar os papéis mais valorizados, o que dava margens a inúmeros conflitos, a ponto de termos afirmado que, muitas vezes, as crianças passavam mais tempo tentando definir papéis e brincadeiras do que propriamente brincando. Disputavam constantemente os “melhores" papéis sociais (herói, mãe, pai, chefe, professora), relegando os menos valorizados (criança, empregado doméstico, bandido) para as crianças mais passivas e submissas.

A pesquisa relatada na dissertação de mestrado foi realizada com crianças de classe média alta. Minha preocupação com o padecimento das pessoas das classes sociais menos favorecidas - com quem trabalhei por muitos anos em Postos de Saúde da periferia demandava que eu procurasse alguma implicação social em meu trabalho de doutorado. Procurei, então, durante o curso, observar crianças das classes trabalhadoras, tendo concluído um estudo numa instituição filantrópica, cujo principal objetivo era averiguar como se refletia nas brincadeiras de faz-de-conta a singularidade da vida de crianças em situação de risco social. Comento, no capítulo final, alguns resultados encontrados no estudo com essas crianças.

Nessa época, tomei contato com o trabalho da colega de doutorado Yumi Gosso, que convivera com os índios Parakanã e investigara seu brincar. Ao ter conhecimento das atividades lúdicas das crianças indígenas, de sua cultura e do fato de que elas praticamente não apresentavam competição por recursos, dividindo-os harmoniosamente, foi tomando vulto a curiosidade em entender melhor as relações entre cultura, brincadeira e conflito. O curso de evolução humana, ministrado pelos professores Fernando José Leite Ribeiro, Emma Otta e Vera Silvia Raad. Bussab, e a disciplina de comunicação não-verbal, conduzida pela Profa. Emma 
Otta, contribuíram muito para que eu passasse a me interessar cada vez mais por conhecer as relações entre natureza e cultura.

Nesse mesmo período, as Profas. Emma Otta e Vera Silvia Raad Bussab tomaram a iniciativa de constituir um grupo de estudos composto principalmente por seus orientandos. Esse grupo ocupou-se de diversas questões que nos inquietavam. Grande parte de nossos estudos foi dedicada ao conflito, fenômeno com o qual estava pouco familiarizada e que ansiava por conhecer. Meu foco de interesse voltou-se para os estudos interculturais e passei a considerar a perspectiva de comparar dados de brincadeiras e conflitos de crianças paulistanas com os daquelas que viviam numa pequena comunidade, mais próximas da natureza e com menor interferência dos avanços tecnológicos. Por razões que aponto no decorrer do trabalho, escolhi, como elemento de comparação com as crianças de São Paulo, um grupo de crianças caiçaras, moradoras de uma região afastada do centro urbano do município de Ubatuba,

Yumi Gosso e eu fizemos, em conjunto com a Profa. Emma Otta, alguns trabalhos comparando os dados obtidos com os índios, os caiçaras e as crianças paulistanas. Fomos convidadas pela Profa. Ana Maria Almeida Carvalho a participar de um livro do qual era co-organizadora, intitulado "Brincadeira e cultura: Viajando pelo Brasil que brinca". Passamos, então, a participar de congressos ao lado de um grupo que estuda brincadeiras das crianças brasileiras dentro de uma perspectiva psicoetológica, composto por professores de diversas regiões: Ana Maria A. Carvalho (USP, São Paulo), Maria Isabel Pedrosa (UFPE, Pernambuco), Ilka Dias Bichara e Eulina da Rocha Lordelo (UFBA, Bahia), Celina Maria Colino Magalhães e Fernando Augusto Ramos Pontes (UFPA, Pará). As participações em congressos - experiências inestimáveis para minha formação, incentivadas pela Profa. Emma Otta - trouxeram a oportunidade de conhecer novas pessoas e de tomar contato com diversos estudos e diferentes concepções acerca do desenvolvimento humano.

O contato com pesquisadores da brincadeira infantil estendeu-se para fora do Brasil, quando Yumi Gosso apresentou nossos trabalhos, em co-autoria com a Profa. Emma Otta, na 33a . Reunião Anual da Sociedade Jean Piaget, realizada em 2003 na cidade de Chicago. Nesse evento, Yumi conheceu Peter Smith - grande estudioso do brincar dentro de um enfoque etológico. O contato da colega Yumi Gosso com Peter Smith resultou no honroso convite para participar de uma publicação organizada por ele e Anthony Pellegrini, escrevendo um capítulo sobre o brincar dos caçadores-coletores. Esse trabalho, elaborado em conjunto com os professores Fernando J. L. Ribeiro, Vera Silvia R. Bussab e Emma Otta, está em vias de ser publicado pela Editora Guilford. 
Durante o programa de doutorado, tive ainda oportunidade de assistir a aulas de professores convidados, dentre eles o Prof. Jaan Valsiner e a Profa. Le Maner-Idrissi, cujos trabalhos exerceram também alguma influência sobre meu pensamento.

Guardo as mais gratas lembranças do período em que cursei o doutorado. Não se tratou apenas de resgatar os estudos e de avançar no conhecimento. A experiência que resultou nesta tese foi muito além disto: foi um norte, uma mudança de rumo, que consolidou os saberes adquiridos em mais de meio século de existência. Ela representa, portanto, muito mais do que um trabalho para obter um título. Tornou-se um projeto de vida que me alavancou para a retomada do contato com um mundo sempre novo: o da pesquisa e da busca do conhecimento.

\subsection{Perspectivas de análise e plano do trabalho}

O tema deste estudo, que diz respeito a semelhanças e diferenças interculturais, enseja uma discussão que se coloca de imediato e que é motivo de cisão e até de sectarismo nas ciências sociais: as relações entre natureza e cultura. Não pretendendo retomar a antiga discussão que dicotomiza inato x aprendido, ou natureza x cultura, consideramos que natureza e cultura são partes indissociáveis na constituição e explicação do comportamento humano. Portanto, na elaboração deste trabalho, procuramos manter duas perspectivas fundamentais: (i) que o homem é resultado de uma extensa cadeia evolucionária, que lhe propiciou características básicas ao longo de milênios de adaptação aos mais diversos ambientes em que se instalou e, (ii) ao mesmo tempo, desde que passou a dominar a linguagem e os sistemas simbólicos em geral, tornou-se um ser histórico e cultural.

Como salienta Hinde (1987), compreender a natureza humana não significa de forma alguma que pretendemos minimizar a importância das desigualdades sociais, e sim levantar questões que ajudem a compreender suas bases. As forças culturais afetam os indivíduos, mas o inverso também é verdadeiro e é com essa dialética que temos de lidar.

Mecanismos mentais universais estão subjacentes a variações superficiais entre culturas. Pinker (2002) usa a linguagem como exemplo da flexibilidade do comportamento. Os seres humanos falam cerca de 6.000 línguas mutuamente ininteligíveis. No entanto os programas gramaticais diferem muito menos do que a fala real. Todos os idiomas são arquitetados de tal forma que podem transmitir qualquer idéia ou proposição.

Extrair o que há de comum dentro da variação dos padrões culturais é uma forma de organizar dados esparsos e de entender processos e mecanismos que subjazem ao 
comportamento humano. Partilhamos, como Hinde (1987), das idéias dos estudiosos que advogam uma preocupação com o particular, com o circunstancial e com o concreto, mas sob uma apreensão organizada e dirigida em termos de análises teóricas da evolução física, do funcionamento do sistema nervoso, dos processos psicológicos e dos padrões culturais sobretudo, porém, estruturada com base no intercâmbio entre esses aspectos.

A vida mental deve ser compreendida em vários níveis de análise. Esses níveis incluem: sua função num sentido último, evolutivo; sua operação em tempo real; sua implementação no tecido neural; seu desenvolvimento no indivíduo; sua evolução na espécie; sua constituição em diferentes culturas e condições sócio-históricas. As vantagens obtidas em se ligarem os níveis de análise social e cultural aos níveis biológico e psicológico são as descobertas que não poderiam ser feitas dentro das fronteiras de uma única disciplina, como os universais da beleza, da lógica da linguagem e dos componentes do sentido moral. Nossa compreensão de nós mesmos e de outras culturas só pode ser enriquecida pela descoberta de que nossas mentes são compostas de circuitos intrincados de pensamentos, sentimentos e de uma grande capacidade de aprendizagem (Pinker, 2002).

Ao mesmo tempo, devemos considerar que a série de fenômenos agrupados sob o termo cultura repousa no centro da vida humana e que a psicologia deve contemplar modelos dos mecanismos que criam, sustentam e modificam a cultura e os fenômenos culturais (Tooby \& Cosmides, 1987). A cultura pode ser entendida como um conjunto de inovações tecnológicas e sociais que as pessoas acumulam para ajudá-las a viver, não simplesmente como um conjunto de papéis e de símbolos arbitrários. A cultura é um instrumento para a vida (Pinker, 2002) e, entre outras coisas, ela dispensa os indivíduos de reaprenderem por ensaio e erro, a cada geração, todo um cabedal acumulado (Bussab \& Ribeiro, 1998). Evidentemente, o comportamento humano não deve ser analisado apenas à luz de condições do ambiente humano atual, porque o meio no qual se processou a maior parte da evolução humana caracterizou-se por um modo de vida caçador e coletor.

A abordagem ecocultural, descrita por Greenfield, Keller, Fuligni e Maynard (2003), considera o desenvolvimento do comportamento da criança e a aquisição de cultura como resultantes da interação entre as potencialidades biológicas humanas e a aquisição de condições ambientais. Os processos culturais fundamentam-se num programa ontogenético de desenvolvimento com períodos sensíveis para tarefas de desenvolvimento e modos de aprendizagem cultural diferentes. Considera-se que tais processos evoluíram tanto filogeneticamente no tempo evolucionário, quanto culturalmente no tempo histórico. 
Dentro dessa perspectiva, apresentaremos e discutiremos, no presente trabalho, dados relativos ao comportamento lúdico e aos conflitos interpessoais de crianças de dois grupos culturais observados nos municípios de São Paulo e de Ubatuba, cujas características estão detalhadas no terceiro capítulo. Referenciando-nos a elementos da literatura, tecemos, nos capítulos 2, 3 e 4, considerações gerais a respeito de conceitos usados no trabalho. Procuramos definir cultura, brincadeira, conflito e zombaria, buscando abordar esses fenômenos dentro de quadros teórico-conceituais que pudessem contribuir para a explicação dos fatos empiricamente constatados.

No quinto capítulo, estabelecemos os objetivos e algumas hipóteses iniciais de que partimos. No sexto capítulo, descrevemos o método utilizado, definimos as categorias em que nos baseamos e relatamos como foram computados e analisados os dados obtidos. No capítulo 7 , descrevemos os principais resultados relativos às brincadeiras dos grupos observados e, no capítulo 8, os atinentes à zombaria e aos conflitos. Procuramos verificar, através de análises estatísticas, eventuais influências do grupo cultural e do gênero das crianças sobre os comportamentos abordados. Selecionamos, ainda, alguns dados qualitativos que pudessem caracterizar melhor as interações sociais das crianças e demonstrar concretamente comportamentos relativos aos temas de que tratamos. Comentamos alguns trabalhos científicos que se dedicaram aos temas em pauta e que trouxeram subsídios teóricos e evidências empíricas que pudessem contribuir para a compreensão dos fenômenos estudados.

No capítulo final, fazemos algumas considerações gerais acerca dos achados do estudo à luz das idéias e constatações de alguns autores, cujas linhas de pensamento e de investigação procuram integrar explicações biológicas e culturais e respeitam características que acreditamos universais na espécie humana: o imenso potencial genético que lhe confere uma especial predisposição para aprender e sua inserção dentro dos processos culturais desde o momento de seu nascimento (Bussab, 2003; Oliva, 2004; Rodrigues \& Otta, 2002; Seidl de Moura, 2004). 


\section{APRENDENDO E FAZENDO CULTURA}

Neste capítulo, tecemos algumas considerações teóricas e metodológicas que nos levaram a adotar como objeto principal deste estudo a comparação de comportamentos de crianças inseridas em grupos culturais diferentes.

\subsection{Cultura e estudos interculturais}

Pelas mesmas razões segundo as quais devemos distinguir entre as circunstâncias atuais em que vive o homem daquelas em que viveram nossos ancestrais e sob as quais o comportamento evoluiu, torna-se importante comparar a conduta humana num dado contexto não só com aquela existente em sociedades que conservaram o modo de vida original de adaptação, como também com a conduta em outras civilizações que se ergueram sobre bases diferentes. Estudos comparativos interculturais são essenciais na busca de processos e produtos de desenvolvimento, tanto universais, quanto específicos de cada grupo social (Seidl de Moura, 2003).

A melhor maneira de ganhar conhecimento sobre a humanidade, segundo Bruner (1990), é pelo uso do método comparativo: a) comparando seres maduros e imaturos de nossa espécie (conceito de desenvolvimento); b) situando o Homo sapiens na escala de outras espécies, construindo um quadro evolucionário; c) procedendo à comparação cultural - de que forma diferentes culturas, subculturas e circunstâncias históricas condicionam o comportamento humano; d) comparando o enfrentamento adequado de problemas com as lutas dos mentalmente doentes, dos socialmente marginalizados, dos moralmente desencorajados; e) comparando o ser humano atual com sua imagem invocada no mito, na poesia e nas miríades de formas de reconstrução imaginativa - onde se enquadram as brincadeiras. 
Conquanto fuja do escopo do presente estudo discutir mais profundamente a conceituação de cultura, uma vez que esse tem sido, por si só, tema de inúmeros debates (cf. Berry, Poortinga, Segall, \& Dasen, 1992), procuraremos situar-nos diante da questão para explicitar o que entendemos pelo termo cultura e de que forma o empregamos no decorrer do trabalho. Berry et al. (1992) adotam uma definição bastante sucinta, considerando cultura como o "modo partilhado de vida de um grupo de pessoas" (pág. 1). Oliveira (1982) entende cultura como o espaço real das relações dos homens entre si e com o seu mundo. Carvalho (1989) concebe cultura como as ações humanas e seus frutos, que constituem a identidade de um grupo humano. Para Greenfield et al. (2003), cultura é um processo socialmente interativo de construção, compreendendo atividades (práticas culturais) e significados (interpretações) partilhados. Ambos os processos são "cumulativos por natureza e ocorrem entre as gerações e dentro delas" (pág. 2). Os mesmos autores afirmam que cultura subjetiva é um modo característico de um grupo perceber seu ambiente social e nela incluem os sistemas de significados e de crenças, relações interpessoais, normas, valores e atitudes que dão conta da interação das pessoas em vários contextos sociais. Não obstante todas as definições impliquem conceitos muito semelhantes e afirmem que cultura é algo compartilhado pelas pessoas (P.B. Smith, 2002), pautamo-nos na definição de Greenfield et al., pois, a nosso ver, é a mais clara, detalhada e completa.

Considerando-se a extensão geográfica do Brasil, sua diversidade sociodemográfica e histórico-cultural, podemos falar em pluralidade cultural brasileira. Assim também pondera Oliveira (1982), ressaltando os contrastes da cultura brasileira. A propósito das diferenças culturais dentro dos E.U.A., Conway, Ryder, Tweed e Sokol (2001) comentam que a variação regional no interior de uma mesma nação é um precioso recurso para analisar relações interculturais que são normalmente estudadas em nível internacional. Segundo Triandis (2002), as subculturas emergem porque as pessoas que vivem num mesmo país partilham, além da língua, elementos como gênero, tipo físico, vizinhança, ocupação, padrão de vida, recursos, condições geográficas, clima, etc. P. B. Smith (2002) refere-se a culturas de times, de grupos e de organizações. Tudge (2003) também considera que diferenças regionais dentro de um mesmo país, assim como realidades socioeconômicas diversas, podem ser elementos que determinam a formação de culturas distintas. Justifica-se, portanto, a nosso ver, a aplicação do termo variação e comparação intercultural quando analisamos semelhanças e diferenças entre grupos regionais e entre comunidades de diferentes níveis socioeconômicos, mesmo que vivendo dentro de uma mesma zona metropolitana. 


\subsection{Diferenças culturais conforme caracterização do self, natureza das relações e modos de produção social}

Consideramos que diferentes dimensões podem ser usadas para caracterizar aspectos culturais que distinguem as sociedades. Escolhemos duas abordagens como referenciais básicos para explicar as diversidades culturais. A primeira diz respeito à diversidade de estilos de criação, que, segundo Greenfield et al. (2003), seguiriam dois caminhos básicos de socialização: a interdependente e a independente. A segunda, inicialmente proposta por Bernstein (1977) e posteriormente transformada por Nicolaci-da-Costa (1988), diz respeito à perspectiva segundo a qual se estabelecem diferentes códigos de comunicação em função de bases mais simples ou mais complexas sobre as quais se fundamentam as sociedades. Além dessas abordagens, pautamo-nos também em especificidades que a dimensão temporal pode adquirir em diferentes culturas, sob duas perspectivas: (i) a percepção subjetiva do transcurso do tempo e (ii) a velocidade em que ocorrem transformações socioculturais - e o valor que as tradições assumem - em diferentes grupos populacionais.

Sabemos que essas explicações e modelos não podem dar conta da complexidade dos fenômenos culturais, nem os consideramos totalmente aplicáveis a todos os elementos da cultura. Entendemos também que os modelos explicativos não devem ser empregados de forma dicotômica, o que equivale a dizer que nenhuma sociedade atual pode ser considerada como totalmente tradicional ou inovadora, nem inteiramente baseada em códigos simples ou complexos de comunicação, nem em modelos de identidade partilhada ou diferenciada, nem que determinado grupo social promova apenas dependência ou independência entre seus membros.

As diversas culturas, com suas diferentes histórias e condições de adaptação, apresentam entre si diferenças em tantas dimensões que seria simplificar em demasia tentar explicar suas características com base em modelos que as polarizam. Em todas essas dimensões, pressupõe-se que exista um contínuo. Tendo presentes as ressalvas apontadas, entendemos que os referenciais descritos, considerados em conjunto, complementam-se no encaminhamento das discussões a respeito de diferenças culturais. 


\subsubsection{Estilos de criação e caminhos de socialização}

As discussões de Keller (1998, 1999) sobre os diferentes caminhos de socialização trazem luz sobre os fundamentos da constituição de modelos básicos de sociedade. A autora situa a concepção do self e das relações interpessoais num sistema primário, que diz respeito ao estilo de criação desde o nascimento da criança e que irá determinar ações e valores culturais prevalentes. Em decorrência, originará orientações culturais individualistas ou coletivistas.

O modelo proposto por Keller (1998) implica dois caminhos principais de desenvolvimento, a partir de dois tipos de cuidados parentais (A e B), esquematizados no Quadro 2.1. O tipo A caracterizaria as culturas ocidentais e o B, as não ocidentais.

Quadro 2.1. Tipos de cuidado parental segundo Keller (1998).

\begin{tabular}{|l|l|l|}
\hline & \multicolumn{1}{|c|}{ Tipo A (ocidental) } & \multicolumn{1}{c|}{ Tipo B (não ocidental) } \\
\hline Aleitamento & durante um a três meses & durante dois a quatro anos \\
\hline Carregar & $\begin{array}{l}\text { principalmente como uma } \\
\text { breve resposta ao choro }\end{array}$ & $\begin{array}{l}\text { mais de 50\% do tempo nos } \\
\text { primeiros anos }\end{array}$ \\
\hline Contato corporal & pouco, culturas de berço & dia e noite \\
\hline $\begin{array}{l}\text { Cuidado extra- } \\
\text { maternal }\end{array}$ & ajuda paga & outros parentes, irmãos \\
\hline $\begin{array}{l}\text { Cuidado } \\
\text { emocional }\end{array}$ & $\begin{array}{l}\text { - curtos períodos de cuidado } \\
\text { exclusivo } \\
\text { - breves episódios face-a-face } \\
\text { - incentivo à independência } \\
\text { precoce }\end{array}$ & $\begin{array}{l}\text { - extensos períodos de contato } \\
\text { - contato e comunicação } \\
\text { corporais prolongados } \\
\text { - apoio a uma longa simbiose }\end{array}$ \\
\hline
\end{tabular}

$\mathrm{Na}$ fase que denomina de recepção (de zero a três anos de idade), em que a criança adquire os conceitos de self e de relação, Keller (1998) classifica os ambientes de criação de acordo com o meio social e a estrutura de atenção. No tipo de cuidado ocidental, o foco da atenção volta-se exclusivamente para a criança, enquanto o cuidado co-ativo (das culturas não ocidentais) implica uma distribuição da atenção a diferentes focos ao mesmo tempo. Na família ocidental, as crianças pequenas passam a maior parte do dia sozinhas com suas mães (ou substitutas). Nas sociedades não ocidentais, mãe e criança passam o dia partilhando atividades com outros membros da família ou inseridas na vida comunitária. Keller diferencia, então, contextos múltiplos - em que há várias pessoas como parceiras interacionais - de diádicos - em que a mãe (ou cuidadora) e a criança ficam sozinhas a maior parte do tempo. Nos contextos diádicos, prevalece um modo distal de interação, voltado principalmente para a troca verbal, 
enquanto, nos co-ativos, o modo prevalente de interação é o contato corporal, que transmite calor emocional.

Segundo Keller (1998), a contingência parental de reação rápida favorece as experiências de causalidade, de previsibilidade e de controlabilidade, ao passo que o contexto de contato corporal propicia a experiência de calor emocional, que, por sua vez, favorece sentimentos de empatia e de condescendência. Pode-se dizer, portanto, que as culturas ocidentais promovem a autonomia precoce e a estrutura diádica-distal exclusiva, dirigida para controlar o ambiente resultando numa definição do self como agente -, enquanto as não ocidentais envolvem cuidado múltiplo e co-ativo e contato corporal íntimo - acarretando um conceito de self como co-agente. $\mathrm{Na}$ fase de aquisição (dos três anos à entrada na puberdade), as culturas ocidentais enfatizam o pensamento abstrato e lógico, enquanto as não ocidentais destacam a observação, a atenção, a aprendizagem rápida, a memória, ao lado da destreza manual e de competências sociais éticas, como dever, responsabilidade, honestidade, respeito e obediência.

Sumarizando, Keller (1998) afirma que a identidade ocidental surge como construção cognitiva a partir de processos ativos de comparação social, enquanto, nas sociedades não ocidentais, a estruturação da identidade consiste predominantemente da adoção de um papel consignado.

Keller (1999) propõe ainda quatro sistemas para a classificação dos preceitos parentais: (1) o sistema de cuidado primário, que se refere a necessidades biológicas básicas, filogeneticamente mais antigas, como alimentação, abrigo e higiene; (2) o sistema de contato corporal, definido pelo carregar e pelo grau de contato corporal; (3) o sistema de estimulação, que envolve atividades diádicas adulto-bebê e proporciona experiências sensório-motoras desafiadoras, contingentes às reações da criança; (4) o sistema face-a-face, caracterizado por contato de olhar e uso freqüente da linguagem. Mediante esse quarto sistema, que a autora considera característico das sociedades ocidentais, o bebê pode perceber-se como causa das ações dos pais através da reação do adulto a seus sinais. O investimento diferencial nesses quatro sistemas compõe características culturais diversas. De acordo com a quantidade e a qualidade de experiências parentais iniciais, a personalidade cultural pode ser classificada numa matriz psicológica alimentada pelo sistema de cuidado primário e por sentimentos de vinculação (self social) - originada no sistema de contato corporal e na consciência corporal - ou numa matriz fundamentada na individualidade, que se baseia no sistema face-a face (self mental).

Embora as características apontadas acima digam respeito predominantemente a distinções entre culturas de diferentes países, sendo freqüentemente utilizadas para descrever as 
diferenças entre as sociedades ocidentais e orientais, servir-nos-ão como referencial para, entre outros fins, caracterizar os grupos observados neste estudo. Estudamos, de um lado, crianças que vivem numa megalópole industrial (município de São Paulo) e, de outro, crianças que vivem numa pequena comunidade praiana (Praia de Itamambuca, no município de Ubatuba). Ambos os grupos vivem no mesmo Estado, falam a mesma língua, estão sujeitos às mesmas leis. Enquanto a influência da civilização euro-americana se faz sentir mais presente na metrópole, chega lentamente, atenuada e transformada - através dos turistas em férias e de imigrantes que adotaram uma visão de vida alternativa àquela que se tem numa metrópole - a uma zona habitada por uma população local que preservou hábitos e costumes tradicionais, menos ocidentalizados no sentido empregado por Keller (1998). Portanto, muitos dos referenciais utilizados nas comparações de características culturais internacionais prestar-se-ão a caracterizar diferenças entre os grupos estudados no presente trabalho.

\subsubsection{Dimensão simples-complexo}

A discussão da variação dentro da perspectiva simplicidade - complexidade de códigos de comunicação coloca-nos em posição desconfortável, uma vez que pode ser mal compreendida. É importante, portanto, deixar claro que não há aqui juízo de valor implicado, ou seja, não acreditamos que as sociedades mais complexas sejam mais importantes ou mais evoluídas, ou melhores ou mais desejáveis do que as simples: apenas lidam com um volume de informações maior. Não pretendemos afirmar também que o contrário é verdadeiro. Entretanto, é possível que alguns fatores das sociedades mais complexas possam sobrecarregar os homens que nelas vivem, uma vez que a adaptação de nossa espécie ocorreu em contextos mais simples, caracterizados pelo modo de vida caçador-coletor.

A estrutura das relações entre as pessoas e as propriedades dos discursos e práticas em que elas se envolvem constituem as condições que as capacitam a descobrir as implicações dos sistemas de símbolos, relações sociais e práticas de discurso que constituem seu modo de vida. Dessa forma, segundo Lock (2000), léxicos com relativamente poucos termos tendem a ocorrer em conjunção com culturas relativamente simples, enquanto léxicos com muitos termos tendem a ocorrer associados a culturas e a tecnologias complexas. Os sistemas referenciais se tornam mais elaborados à medida que as sociedades aumentam em complexidade

Bernstein (1977) propõe dois tipos de código de comunicação: o restrito e o elaborado. Essa distinção não é dada por variações da língua e sim por princípios de estruturação que sustentam 
formas lingüísticas e sociais diversas. Esses códigos também controlam outros sistemas semióticos, além da linguagem: sistemas de regras de vestuário, de alimentação, de rituais e de adornos corporais, entre outros. Os códigos propiciariam os princípios de transmissão cultural, regulando a reprodução de visões de mundo e da própria estrutura social. A segregação dos códigos entre diferentes estratos sociais não se dá ao acaso, mas de acordo com os requisitos de cada um. A divisão de trabalho e a diferenciação das sociedades de larga escala geraram as mais diferentes disciplinas, cada uma das quais com seu vocabulário especializado. As pessoas com condições satisfatórias de vida, ou seja, em nossa sociedade, as de classe média e alta, segundo Lock (2000), deteriam uma metalinguagem de termos universais e de noções abstratas características do código elaborado. $\mathrm{O}$ autor acrescenta que o fundamento para essa diferenciação entre sistemas culturais seria compatível com a idéia vygostkiana segundo a qual o conhecimento é produzido em situações de interação.

Sociedades simples e homogêneas não exerceriam pressão sobre a criação de significados codificados em termos independentes do contexto (Lock, 2000). Na falta de especialistas, todo membro da sociedade precisa ter respostas úteis e testadas pelo tempo para os mais freqüentes problemas do dia-a-dia. Essencialmente, os membros das culturas simples confiariam mais no conhecimento tradicional e nas soluções de senso comum, para as quais não são necessárias sofisticadas abstrações.

Desde o início da história do Ocidente até nossos dias, as funções sociais tornaram-se cada vez mais diferenciadas, sob a pressão da competição. Na medida em que a maior parte das pessoas precisa sintonizar suas ações com as dos outros, a rede de ações se torna mais precisamente organizada e é necessário que o indivíduo regule sua conduta de maneira crescentemente diferenciada.

O mesmo fenômeno é focalizado por Nicolaci-da-Costa (1988), que considera dois modelos de socialização. A autora refere-se ao código restrito como "modelo de identidade compartilhada" e ao código elaborado, como "modelo de identidade diferenciada". Nas sociedades estratificadas, o primeiro seria típico das classes trabalhadoras e o segundo, das classes média e alta. O modelo de identidade compartilhada enfatizaria a semelhança entre os membros de um determinado grupo social, reduzindo a necessidade de o indivíduo elaborar verbalmente suas experiências, intenções ou motivações pessoais. Assim sendo, algumas áreas do self teriam pouca probabilidade de se tornar objeto de atenção por parte do sujeito. Nicolacida-Costa argumenta ainda que a identidade social promovida pelo código restrito é fortalecida por um tipo de controle familiar em que importa a posição socialmente definida ocupada por 
determinado membro da família. A essa posição na família corresponde um conjunto de direitos e de deveres inconfundíveis. Para a manutenção dessa posição, é facultado o uso de diversos tipos de punição quando um elemento da família infringe alguma regra pré-estabelecida.

Por sua vez, o modelo de identidade diferenciada promove a atenção a processos internos, a diferenças individuais e enfatiza o planejamento. Acentua a diferença entre os membros de um grupo social, sendo a linguagem veículo fundamental para a comunicação de experiências, de intenções e de motivações individuais. Áreas inteiras do self podem ganhar visibilidade para o próprio sujeito e para os outros. As características individuais dos membros da família são levadas em conta, havendo maior flexibilidade na aplicação de regras e na definição de papéis. A autoridade é exercida através do manejo verbal dos sentimentos e da responsabilização da criança por seus atos.

Seguindo essa linha de raciocínio, é necessário notar que há comunidades ou culturas em que as condições socioeconômicas são tais que a necessidade de sobrevivência condiciona o desenvolvimento da inteligência relativa a habilidades físicas, ao pensamento concreto e à busca de soluções imediatas para os problemas práticos que seus membros - sejam eles crianças ou adultos - enfrentam no dia-a-dia. Dentro dessa perspectiva, consideramos que as crianças paulistanas observadas, advindas, em sua maioria, da classe média e vivendo numa grande metrópole, estão inseridas num contexto mais próximo do modelo de identidade diferenciada, enquanto as crianças de Ubatuba - que fazem parte de uma comunidade pequena, com valores mais tradicionais e condições socioeconômicas mais restritas - situam-se num contexto compatível com o modelo de identidade partilhada.

\subsubsection{Dimensão temporal}

Consideraremos brevemente dois aspectos inter-relacionados da dimensão temporal: o valor que o tempo cronológico assume em determinadas realidades sociais - e sua conseqüente percepção subjetiva - e a velocidade das mudanças imprimidas a diferentes grupos culturais. Greenfield et al. (2003) afirmam que, por um lado, em comunidades onde as mudanças são lentas, com ecologias baseadas na subsistência, a cultura é transmitida verticalmente de geração para geração, maximizando a continuidade histórica. Por outro lado, em sociedades complexas de mudanças rápidas, as idéias dos pais são negociadas horizontalmente dentro das gerações e pautadas no discurso público da mídia e dos especialistas. Nessas sociedades, as idéias parentais diferem substancialmente entre as gerações, as obrigações sociais são individualmente 
negociadas, há oportunidade de selecionar os relacionamentos sociais e de agir livremente (com base nos direitos individuais). Em contraposição, num caminho de socialização interdependente, as prioridades se conformam a normas sociais tradicionalmente estabelecidas e a escolha individual torna-se menos importante.

Georgas (2003) afirma que modificações trazidas pelo turismo e pelo intercâmbio comercial para as sociedades tradicionais influenciam muito lentamente os valores previamente estabelecidos. Evidentemente, a velocidade das mudanças sociais depende da forma como essas influências se exercem (Otta, comunicação pessoal). Se as modificações nas relações estabelecidas pelo turismo e pelo comércio forem muito intensas e invasivas, provavelmente acarretarão transformações mais abruptas e menos organizadas nas sociedades que sofrem sua influência. Ao passo que as mudanças introduzidas gradualmente e com respeito pelos costumes nativos terão impacto muito menor na cultura local. Tendo a comunidade ubatubana vivido relativamente isolada até a década de 1970 (Oliveira, 1977), supõe-se que ela seja norteada por valores mais tradicionais, em contraposição com a metrópole de São Paulo, que, com base numa economia industrial, comercial e de serviços, em constante modernização, vem sofrendo influências culturais externas e diversas há muito tempo.

Outra dimensão do tempo, a dimensão psicológica (Andersen, 1999), difere entre uma grande metrópole e uma comunidade de pequena escala. Por um lado, nos grandes centros urbanos - em que as distâncias são grandes e percorridas lentamente por causa do excesso de veículos e em que o volume de produção se estabelece como importante fator de competição -, o tempo é considerado insuficiente e a percepção subjetiva predominante é de que ele se esvai rapidamente. Por outro lado, nas comunidades de pequena escala, o ritmo de vida é espaçado, há pouca pressão por acelerá-lo e a percepção subjetiva é de que o tempo transcorre lentamente (Conway et al., 2001). Pode-se afirmar, com relativa segurança, que o ritmo de vida é mais espaçado na comunidade ubatubana e mais acelerado na paulistana.

Louzada (2000), estudando o ciclo de vigília/sono de adolescentes de três grupos populacionais - um urbano da cidade de São Paulo, dois de zonas rurais dos municípios de Piracicaba e de Ubatuba, respectivamente -, encontrou que os estudantes de zona urbana apresentavam fases do ciclo atrasadas em relação aos de zona rural. Os primeiros dormiam e acordavam mais tarde do que os últimos. $\mathrm{O}$ autor verificou, ainda, que estudantes do turno vespertino da área urbana relatavam maior sonolência durante as aulas e tinham um período de sono mais curto do que os de zona rural. Tais constatações o levaram a concluir que o horário escolar no turno matutino e o contexto social urbano seriam situações que propiciariam a 
ocorrência de uma diminuição na duração do sono, com conseqüente aumento da sonolência diurna. Podemos supor que a maior duração do sono nas populações de áreas rurais também esteja relacionado com a dimensão subjetiva de tempo.

Conjecturamos que a dimensão temporal se manifeste diferentemente nas brincadeiras e

conflitos das crianças dos dois grupos culturais. É provável que se encontrem brincadeiras mais tradicionais no grupo de crianças de Ubatuba e maior influência dos meios eletrônicos e dos conteúdos veiculados pela mídia no brincar das crianças paulistanas. Supõe-se, também, que os valores presumivelmente mais estáveis e conservadores da sociedade ubatubana ensejem um número menor de desentendimentos entre as crianças. Acreditamos que será difícil avaliar a percepção subjetiva do tempo e seus reflexos no comportamento através do método utilizado.

\subsection{Diferenças de gênero}

Nas sociedades conhecidas, tanto as ocidentais quanto as tradicionais, os papéis masculino e feminino divergem, assim como as expectativas em relação a homens e mulheres. Ao que tudo indica, essas diferenças teriam sido consolidadas no ambiente de adaptação da espécie humana (Hinde, 1987); ou seja, é possível que o ambiente em que viveram nossos ancestrais tenha dotado homens e mulheres de propensões comportamentais diferentes. É, portanto, de se esperar que, dadas as diferenças anatômicas, funcionais e hormonais e as influências do ambiente, desde cedo as crianças apresentem diferenças no comportamento em função do sexo.

Harris (1998) relata estudos que demonstram que, quando se comparam estereótipos de gênero de diversas sociedades, encontram-se grandes semelhanças entre o que é esperado do comportamento e das atitudes de homens e mulheres. Cita como exemplo uma pesquisa efetuada com estudantes de 25 países diferentes, que foram solicitados a relacionarem diferentes adjetivos aos dois sexos. Em todos os países investigados, os homens foram associados a adjetivos como agressivo, ativo, inquieto e duro e as mulheres foram associadas a adjetivos como afetuosa, cautelosa, sensível e emocional.

Archer (1996) apresenta uma série de dados que revelam que os homens são mais assertivos, ao passo que as mulheres se mostram mais ternas e ansiosas - fato que pode estar ligado à maior necessidade dos homens de demonstrarem controle emocional. Segundo o autor, nas relações de amizade, as mulheres tendem a estabelecer laços mais íntimos e a partilhar sentimentos e experiências, enquanto os homens se associam na base de atividades partilhadas e 
evitam falar de questões pessoais, para não demonstrar vulnerabilidade. A respeito da posse de bens materiais, os homens tendem a encará-la em suas finalidades instrumentais, enquanto as mulheres inclinam-se a considerá-la sob o prisma emocional e relacional. Os homens tendem a exibir menor envolvimento com outras pessoas, ao passo que as mulheres mostram maior necessidade de ter intimidade com os outros. Archer explica esses achados dentro da perspectiva da teoria de seleção sexual, que prediz que as características de assertividade, força, ocultação das emoções e busca de controle sobre as decisões reprodutivas das mulheres estariam relacionadas à competição entre os homens. Em relação às mulheres, essa teoria prediz que elas tenderiam a promover ligações interpessoais e a desempenhar comportamentos que reafirmariam sua prioridade de escolha nas decisões de reprodução. Acrescentaríamos que o papel reprodutivo da mulher e de cuidados com a prole também pode estar associado às características femininas de maior vinculação interpessoal. Sua inclinação à dependência pode estar relacionada com a importância de manter o parceiro próximo para ajudá-la a prover o sustento da prole.

Benenson (1993), estudando crianças, também acredita que, do ponto de vista evolutivo, as meninas teriam uma tendência natural para a interação e seriam preparadas para cuidar do outro e para formar laços interpessoais, com o fim de, futuramente, garantir a sobrevivência dos filhos. Por sua vez, os homens estariam preparados para adotar comportamentos assertivos e causadores de impacto, com as finalidades de prover alimento e de proteger seus parentes de agressores externos.

Embora se verifique em muitos estudos sobre estereotipia sexual uma tendência a se acentuarem as diferenças entre os sexos, Hinde (1987) nos lembra de que há extensa sobreposição entre eles. Embora a evidência disponível, extraída de grupos de caçadorescoletores e de outros grupos indígenas, induza-nos a pensar que, em nosso passado ancestral, tenha havido divisão de trabalho entre homens e mulheres (os homens cooperando na caça e as mulheres coletando vegetais e cuidando da prole), é preciso supor que tenha existido também, como hoje, uma extensa sobreposição entre os sexos em muitas características e que os indivíduos sempre tenham usado estratégias alternativas para atingir seus objetivos.

Sem ignorar os aspectos biológicos mencionados, as concepções de gênero ligam-se a sistemas de crenças na forma de estereótipos e de expectativas codificadas culturalmente (Maccoby, 1988). Certas características universais, algumas das quais relacionadas com a reprodução, vinculam-se a esses padrões. No entanto, como afirma Maccoby (1988), a variação entre os grupos sociais é grande: as diferenças de status entre homens e mulheres podem ser grandes ou 
pequenas e o conteúdo de estereótipos de gênero e de papéis sexuais varia de uma sociedade para outra. Além disso, o grau em que as pessoas se identificam com os papéis de gênero de sua sociedade também mostra grandes modulações.

Diversos pesquisadores têm-se dedicado a identificar diferenças de gênero no comportamento das crianças (Hartup, 1983; Belle, 1989; Benenson, 1993; Benenson et al., 2001; Maccoby, 1988, 1996; Markovits, Benenson \& Dolensky, 2001; Nicolopoulou e Weintraub, 1998 ). Maccoby (1996) e Harris (1998) afirmam que as interações sociais entre as crianças constituem um meio importante de desenvolvimento de comportamentos típicos de cada sexo. Harris enfatiza variáveis situacionais, alegando que meninos "não nascem com aversão a trocar fraldas de bonecas e as meninas não nascem com antipatia por caminhões" (pág.279) e que as diferenças entre os sexos aumentam no decorrer da primeira década de vida.

Durante os anos formadores da infância, a menina se torna mais parecida com as outras meninas e os meninos mais parecidos com os outros: meninas turbulentas tornam-se menos agitadas e meninos tímidos ficam mais ousados. Entretanto é possível que muitas diferenças entre as preferências de crianças de ambos os sexos já existam ao nascer. Connellan, BaronCohen, Wheelwright, Batki e Abluwalia (2000) encontraram que crianças com um dia de vida já demonstravam dimorfismo sexual na percepção de objetos: bebês do sexo masculino mostraram preferência (medida através da duração do olhar) por objetos mecânicos, enquanto as meninas revelaram predileção por faces humanas.

Martin e Fabes (2001) salientam que meninos tendem a estabelecer hierarquias estáveis, enquanto a dominância em meninas é considerada mais mutável. Segundo os autores, meninas enfatizam a cooperação entre os companheiros e usam formas facilitadoras de produção de harmonia no grupo. Meninas preferem selecionar atividades que são mais estruturadas e governadas por regras sociais estritas, tendendo a seguir mais as normas estipuladas pelos adultos. Meninos tendem a realizar atividades mais livres de interferência adulta e a exposição a outros meninos fá-los tender a desenvolver, mais frequientemente do que as meninas, problemas interacionais e estilos anti-sociais. Maccoby (1988) considera que as meninas tendem a usar formas menos diretas de discurso e a ser mais responsivas em relação aos outros. Souza e Rodrigues (2002), estudando crianças brasileiras de oito e nove anos de idade, também encontraram que os meninos apresentavam comportamento mais agitado do que as meninas.

Diversos autores constataram que as crianças preferem associar-se a colegas do mesmo sexo (Harris, 1998; Martin \& Fabes, 2001; Sippola, Bukowski \& Noll, 1997). Martin e Fabes (2001) sugerem que a segregação por sexo afeta o desenvolvimento das crianças, canalizando 
seus interesses e experiências e limitando os tipos de atividades nas quais se envolvem e que, quanto mais elas se expõem a pares do mesmo sexo, mais seus comportamentos se tornam sexualmente diferenciados.

Muitas das explicações para a preferência por brincar com crianças do mesmo sexo dizem respeito à semelhança das atividades preferidas por elas (Harris, 1998; Martin \& Fabes, 2001). Martin e Fabes (2001) propõem, como uma das explicações para a segregação sexual, a compatibilidade comportamental entre as crianças. Por exemplo, meninos muito ativos procurariam companheiros igualmente ativos: presumivelmente, outros meninos. Sippola et al. (1997) sugerem que se examinem as variações nas interações com crianças do mesmo sexo e do sexo oposto sob duas perspectivas: o ponto de vista adotado em relação aos pares do mesmo sexo e o ponto de vista a respeito de colegas do sexo oposto. Os autores encampam a posição de Moreno (1983), segundo a qual gostar e rejeitar são duas dimensões diferentes das relações interpessoais: não são nem opostas, nem relacionadas. Alegam que as pesquisas têm demonstrado que a preferência por crianças do mesmo sexo resulta mais de um viés positivo em relação ao mesmo sexo do que de um viés negativo em relação ao sexo oposto.

Outros achados centrais de estudos que enfocaram a segregação sexual e a estereotipia de papéis de gênero na infância dizem respeito à preferência diferencial por brincar em grupos de tamanhos diferentes: as amizades das meninas são mais focalizadas nas díades, enquanto os meninos tendem a formar laços de grupo. Benenson et al. (2001) observam que, a partir dos cinco anos de idade, evidencia-se - através de vários métodos, incluindo sociogramas de padrões de amizade, observação em contextos padronizados e observação naturalística do comportamento infantil - que meninos preferem interagir em grupos grandes, enquanto meninas preferem interações diádicas. Martin e Fabes (2001) documentam o mesmo fenômeno a partir dos três anos de idade. Esses autores acreditam que tal constatação se deva ao fato de que grupos maiores possibilitem dispersar as fortes emoções causadas pela competição direta entre os indivíduos, propiciando-lhes algum grau de anonimato e assegurando que a lealdade ao grupo tenha precedência sobre as relações individuais. Por sua vez, as meninas, com maior tendência à intimidade interacional, prefeririam as relações diádicas, mais próximas e diretas.

Apesar de todas as diferenças comportamentais entre meninos e meninas apontadas nos trabalhos citados, há que se considerar, em primeiro lugar, que a grande maioria deles são achados relacionados a sociedades européias e norte-americanas e, em segundo lugar, que a diversidade cultural e as especificidades nas configurações dos grupos infantis podem determinar diferentes caminhos para a definição de papéis de gênero. 


\subsection{Síntese}

Neste trabalho, partindo de uma perspectiva psicoetológica, considera-se que o ser humano, como os demais animais, é produto de uma longa cadeia evolucionária. Trata-se de uma espécie essencialmente social, geneticamente dotada da capacidade de vincular-se afetivamente e de se ajustar socialmente a seus co-específicos. Sua capacidade única de simbolizar permitiu-lhe que criasse linguagem e cultura. Assim sendo, a criança nasce e se desenvolve dentro de ambientes socioculturais desenvolvidos por gerações que a precederam, dotada da capacidade de viver em cultura, de adaptar-se a ela e de transformá-la, mediante uma alta flexibilidade comportamental e facilidade de aprendizagem estampada em seus genes (Oliva, 2004). Dada essa especificidade do ser humano, a cultura torna-se um elemento central em seus ambientes de criação e, portanto, indissociável de aspectos biológicos na explicação do seu comportamento social.

Entende-se por cultura a manifestação de um processo socialmente ativo de construção de atividades e de significados partilhados. A comparação entre comportamentos de crianças educadas em diferentes grupos sociais é um importante instrumento para o entendimento da cultura, do desenvolvimento infantil e da interação entre ambos os fenômenos. Nessa perspectiva, este estudo se propõe a comparar as brincadeiras e conflitos de crianças de dois grupos culturais da forma como ocorrem em horários de atividade livre, em dois contextos semelhantes : em uma creche do município de São Paulo e em uma pré-escola, situada num bairro afastado do município de Ubatuba, no litoral norte do Estado de São Paulo.

Como referencial teórico para a explicação de diferenças culturais eventualmente encontradas neste estudo, empregaremos o modelo de estilos de criação e de caminhos de desenvolvimento social proposto por Keller (1998) e a perspectiva de diferentes códigos de comunicação, proposta por Bernstein (1977), modificada por Lock (2000) e Nicolaci-da-Costa (1988). Keller diferencia dois caminhos básicos de socialização: o ocidental, que preconiza a autonomia, a individualidade e a independência e o não ocidental, que enfatiza a interdependência entre os membros de um grupo social e o bem estar coletivo. Bernstein distingue coletividades em que prevalece um código de comunicação simples - como é o caso dos grupos pertencentes a sociedades tradicionais e à classe trabalhadora - daquelas erigidas sobre uma base tecnológica, com alta especialização do trabalho e de papéis, que adotam um código de comunicação mais complexo. 
Além dessas duas perspectivas, adota-se também a dimensão temporal como uma das variáveis que influenciam a evolução de diferentes culturas. De um lado, existem sociedades predominantemente fundamentadas numa economia de subsistência, em que as tradições transmitidas de geração para geração são mais arraigadas e em que o ritmo de vida e de transformações é mais lento; de outro lado, assiste-se a um tipo de sociedade - característico das grandes metrópoles ocidentais - em que os valores são discutidos entre as gerações, modificados de uma geração para outra e em que o ritmo de vida e de mudanças é acelerado.

Considera-se que o grupo cultural de Ubatuba dispõe de um código mais simples de comunicação, de um estilo de criação predominantemente proximal, de um modo de vida mais tradicional e de um ritmo de vida espaçado, enquanto o grupo paulistano enquadra-se numa sociedade que promove o estilo distal e independente de criação, um código de comunicação mais complexo, sendo composta de pessoas que revelam maior adaptabilidade a mudanças rápidas e que denotam uma percepção subjetiva de que o tempo se escoa muito rapidamente.

Diferenças de gênero, embora construídas sobre bases biológicas, estão intimamente relacionadas a variáveis de ordem cultural. Dentre os estudos que se voltaram para a estereotipia dos papéis de gênero em crianças, destacam-se os que revelam que as crianças preferem interagir com pares do mesmo sexo e que meninas preferem interações diádicas, ao passo que meninos interagem predominantemente em grupos grandes. Além dessas diferenças de gênero, diversas pesquisas encontraram que meninas preocupam-se mais com as relações interpessoais e com a intimidade interacional, ao passo que meninos são mais assertivos, independentes e encorajados a demonstrar suas emoções de forma mais contida. Considera-se, ainda, que meninos tendem a participar de atividades menos organizadas, a demonstrar menor proximidade interacional e a centrar-se mais em atividades partilhadas do que nas relações interpessoais. Apesar de todas essas diferenças, ressalta-se que a sobreposição de comportamentos entre os sexos é grande e que a diversidade entre comportamentos masculinos e femininos pode variar substancialmente de um grupo cultural para outro.

\subsection{Caracterização dos grupos culturais estudados}

Sabendo-se da influência dos valores parentais (Farver \& Howes, 1993; Farver \& Wimbart, 1995; Farver et al., 2000) sobre a brincadeira infantil, e considerando as dimensões conceituais anteriormente levantadas - estilos de criação proximal/distal, códigos de comunicação simples/elaborado, modelos de identidade partilhado/diferenciado e a dimensão 
temporal - que caracterizam as diferenças culturais, podemos fazer algumas suposições do que se espera encontrar na comparação entre crianças que se desenvolvem em meios culturais que se encontram em diferentes pontos destas dimensões. No quinto capítulo, após apresentar os conceitos de brincadeira e conflito, formularemos algumas hipóteses iniciais baseadas nas condições de vida das crianças dos dois grupos culturais. Passamos a descrever algumas características dos grupos escolhidos para fazer parte do presente estudo

\subsubsection{Cultura caiçara da região de Ubatuba}

Entendemos que existe, com variações, uma cultura regional caiçara - denominação genérica dada ao nativo e morador das regiões pouco povoadas e da zona rural do litoral paulista. Foi tendo em vista as particularidades geográficas do litoral norte do Estado de São Paulo, mais especificamente do município de Ubatuba (Figura 2.1), bem como suas características sociais, históricas e culturais, que procuramos conhecer melhor o brincar das crianças que ali vivem.

Como este trabalho se propõe a apurar semelhanças e diferenças entre conflitos e brincadeiras de crianças de uma grande metrópole e as atividades lúdicas de crianças de uma zona afastada dos grandes centros urbanos - que, em tese, vivem num ambiente em que há maior contato com a natureza e com os vizinhos e que não sofrem tão diretamente os efeitos da civilização tecnológica, informatizada, governada pela mídia, pelo consumismo e pelo individualismo característicos das grandes cidades -, foram escolhidas as crianças ubatubanas como grupo que representa esse modo de vida, por diversas razões: (1) sendo freqüentadora antiga do litoral do município de Ubatuba, estava familiarizada com seus moradores, seu estilo de vida, sua maneira de ser e de pensar; (2) por se tratar de uma região que dispõe de um vasto espaço físico não habitado, proporciona aos moradores contato constante com uma natureza abundante em espécies vegetais e animais. De acordo com levantamento de 2002 da Fundação SEADE (www.seade.gov.br), o Litoral Norte, ao qual pertence o município de Ubatuba, tem $78,49 \%$ de mata natural (Figura 2.1), contrastando com outras áreas do interior do Estado de São Paulo, onde tal porcentagem não chega a 5\%; (3) a topografia local, bastante diversificada e acidentada, permite a seus habitantes o contato com a praia, com o mar, com a mata e com a serra; (4) razões históricas levaram o município de Ubatuba a um isolamento que apenas se rompeu a partir da década de 1950, com sua exploração turística. Esse relativo isolamento possibilitou que se formasse e se conservasse uma cultura regional própria. 


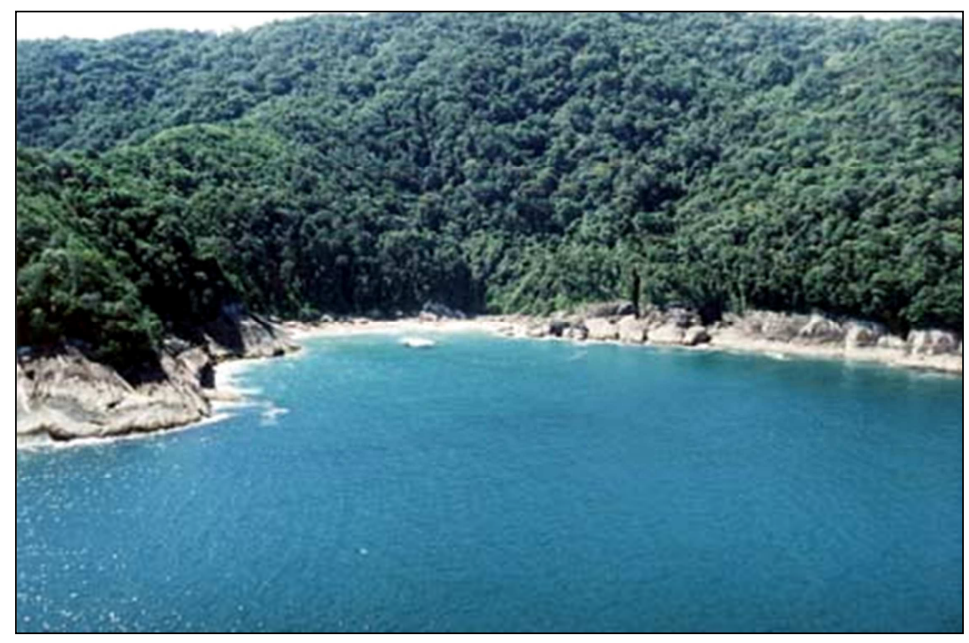

Figura 2.1. Vista da mata, da costeira e de pequena praia de Ubatuba (foto: www.ubatuba.com.br).

Em contraponto, as semelhanças existentes entre os dois grupos culturais, de São Paulo e de Ubatuba, como a língua, a constituição familiar, a orientação sociopolítica geral e o fato de as crianças observadas freqüentarem escolas dentro do sistema educacional do mesmo Estado ajudar-nos-iam a destacar o quanto de seu comportamento se devia a peculiaridades de cada cultura.

Antigo porto de drenagem de minérios e sede de engenhos de cana-de-açúcar, Ubatuba conheceu épocas de prosperidade econômica entre os séculos XVII e XIX. A partir da abolição da escravatura, no final do século XIX, o município viveu anos de decadência econômica e de relativo isolamento até meados do século XX (Oliveira, 1977). Em 1952, com a construção da rodovia Taubaté-Ubatuba, a cidade tornou-se menos isolada. Após 1970, com a pavimentação da rodovia Rio-Santos, o município cresceu muito, recebendo habitantes de outras regiões, de forma que o caiçara típico atualmente, é encontrado principalmente nas regiões mais afastadas, nos bairros e, eventualmente, morando ou trabalhando na cidade. Muitos nativos que viviam da pesca venderam suas propriedades aos turistas e foram afastando-se das praias (Marcílio,1986; Setti, 1985). Esse, aliás, é um dos motivos de ressentimento dos moradores em relação aos turistas. Entretanto, os habitantes da região conservam ainda muitas das características que os definiram. Atualmente, o município conta com uma população fixa de 66.861 habitantes (Censo de 2000 - IBGE, 2004), distribuídos numa área $682 \mathrm{~km}^{2}$ e recebe cerca de 800.000 turistas por ano (www.ubatuba.com.br). 
Pelas peculiaridades geográficas do território do município, recortado por praias, delimitadas por encostas de pedras, por morros e montanhas, alguns caiçaras vivem relativamente circunscritos, em regiões que só permitem acesso por barco ou a pé, através de trilhas e de picadas - o que lhes possibilita conservarem a antiga maneira de viver: alguns ainda vivem da pesca e da agricultura de subsistência. O ubatubano nativo, com sua miscigenação de raças, é, de uma maneira geral, uma criatura que se pode descrever como pacífica, contemplativa e "sossegada". Com essas características, contrastam um andar ligeiro de quem precisa percorrer a pé longas distâncias e um falar típico muito rápido. Muitos cultivam ainda certas tradições, como a música (Setti, 1985), as quermesses, as festas regionais e religiosas. Nas camadas populares, encontramos uma sociedade conservadora em que prevalecem valores e hábitos que sofreram pouca influência do mundo globalizado contemporâneo. Embora grande parte dos moradores possua TV, ainda existe o hábito de "tomar a fresca" no alpendre e de conversar com os vizinhos. A energia elétrica ainda não atinge as regiões mais distantes do centro urbano (Louzada, 2000). Em noites claras, iluminadas pela luz da lua, as crianças brincam no "terreiro". Casar cedo é praticamente uma norma. Muitas pessoas casam-se ao redor dos 20 anos e tornam-se avós por volta dos 40.

Numa família típica de pescadores, o homem é respeitado como chefe da família e a mulher se ocupa dos afazeres domésticos e dos cuidados com a família. Evidentemente, com a influência de valores da sociedade ocidental moderna, muitas mulheres já se ausentam para trabalhar fora. Apesar disso, o modo de vida dos caiçaras pode ser descrito como predominantemente tradicional. A percepção cronológica subjetiva é de que o tempo se escoa lentamente e de que não há grandes diferenças de um dia para o outro. $O$ código de comunicação da cultura ubatubana nativa pode ser considerado simples e o estilo de criação, mais compatível com o modo proximal. Não se nega, contudo, que essa população também esteja exposta às influências exercidas pela pressão de valores globalmente transmitidos, no sentido de promoverem uma educação distal, que incentiva a competição, a autonomia e a independência. Apesar das modificações que vem sendo trazidas pelo turismo e pelo comércio, acreditamos, como afirmam Georgas (2003) e Greenfield et al. (2003), que as transformações sociais das sociedades mais conservadoras não ocorrem com muita rapidez e que muito do modo de viver tradicional se encontra preservado entre os caiçaras. Isso se deve, provavelmente, ao tipo de turismo pouco predatório que chegou até a cidade e ao fato de a extensa e acidentada região geográfica permitir certo isolamento da população nativa. 


\subsubsection{Grupo observado no município de São Paulo}

A grande extensão geográfica do município de São Paulo, com $1525 \mathrm{~km}^{2}$ e 10.434 .252 habitantes (censo de 2000, IBGE, 2004), bem como a composição de sua população, de diversas etnias e classes sociais, propiciam que nessa cidade se encontrem diversos grupos culturais, que variam praticamente de bairro para bairro. Podemos caracterizar a amostra que estudamos como composta de crianças originárias de grupos culturais heterogêneos, que, pela convivência diária e pela semelhança de locais de trabalho ou estudo dos pais, passam a constituir um agrupamento com características próprias. Em sua maioria, os pais dessas crianças eram funcionários de diversos setores de uma universidade pública: alguns eram estudantes universitários, graduandos e pós-graduandos, e outros, professores universitários.

Os participantes do grupo paulistano partilham ainda de condições comuns, pelo fato de todos morarem numa região metropolitana com um modo de vida predominantemente individualista - que propicia pouco contato com os vizinhos e que leva a um tipo de lazer entre quatro paredes -, sob condições de estresse típicas das megalópoles - com altos níveis de violência, longas distâncias a percorrer entre o trabalho e o domicílio, um ritmo de vida acelerado, transporte público lento e precário, residências pequenas com área para brincar restrita. Dadas as características dos pais dessas crianças, é de se supor que adotem um modo de criação distal, que valoriza o conhecimento de si e do mundo e que enfatiza o emprego de símbolos e da abstração.

Tabela 2.1. Comparação entre características e condições de vida dos municípios de São Paulo e de Ubatuba.

\begin{tabular}{|l|l|l|}
\hline \multicolumn{1}{|c|}{ Indicadores } & São Paulo & Ubatuba \\
\hline Densidade populacional (habitantes por $\mathrm{km}^{2}$ - 2000) & 6842 & 98 \\
\hline Porcentagem de área ocupada por mata virgem (2002) & menos de 5\% & $78 \%{ }^{*}$ \\
\hline Homicídios por 100.000 habitantes (2002) & 54,20 & 33,83 \\
\hline Mortalidade infantil por mil nascidos vivos (2000) & 15,10 & 19,51 \\
\hline Longevidade (2000) & 65 & 59 \\
\hline Pontuação de escolaridade (2000) & 90 & 73 \\
\hline Esgoto sanitário (2000) & $89 \%$ & $23 \%$ \\
\hline Renda média do(a) responsável pelo domicílio (reais) & $1.480,00$ & 761,00 \\
\hline Arrecadação per capita em reais (ICMS- 2002) & $1.754,31$ & $\begin{array}{l}46,92 \\
12,46\end{array}$ \\
\hline Índice de Responsabilidade Social (2000) & $\mathbf{5}$ - Baixo & $\begin{array}{l}\mathbf{1}-\text { Município } \\
\text { pólo }\end{array}$ \\
\hline
\end{tabular}

Fonte: Fundação SEADE

*Dados referentes ao Litoral Norte. 
$\mathrm{Na}$ Tabela 2.1, transcrevemos alguns indicadores encontrados nos perfis municipais das duas cidades, fornecidos pela Fundação SEADE (www.seade.gov.br). Embora a cidade de São Paulo se caracterize por uma grande mescla de níveis socioeconômicos e culturais, os dados apresentados dão uma idéia geral de como se constituem os dois municípios.

Os principais contrastes que se verificam através dos indicadores da Tabela 2.1 dizem respeito ao desempenho inferior de Ubatuba em: condições de saúde (constatadas pela longevidade e mortalidade infantil, e, indiretamente, pela rede de esgotos); renda familiar média e escolaridade; arrecadação de impostos (que serve para caracterizar o desenvolvimento econômico da região), muito mais baixa do que a de São Paulo. Por sua vez, Ubatuba supera São Paulo na preservação da mata Atlântica, revela condições mais favoráveis de adensamento demográfico (muito mais baixo do que o da grande metrópole) e menor número de homicídios, dado que, provavelmente, indica menor nível de violência na cidade praiana.

No capítulo que se segue, apresentaremos algumas considerações acerca do brincar, que permitirão estabelecer relações entre as atividades lúdicas e as condições de vida das crianças. 


\section{3. É PRECISO BRINCAR}

A forma infantil espontânea de se expressar através da brincadeira é, sem dúvida, um importante elemento para estudos comparativos entre espécies animais e entre culturas humanas (Bekoff \& Byers, 1998; Brougère, 1998; Eibl- Eibesfeldt, 1989). Diversos estudos realizados em diferentes sociedades, bem como em grupos culturais brasileiros distintos (cf. Carvalho, Magalhães, Pontes \& Bichara, 2003), têm apresentado evidências nesse sentido.

\subsection{Conceituação do brincar}

Embora possamos identificar quando um animal está brincando, não tem sido fácil haver acordo entre os teóricos sobre a definição do brincar, conquanto grande parte de psicólogos e etólogos (Eibl-Eibesfeldt, 1970; Fagen, 1981) concordem que, nas atividades lúdicas, estão presentes comportamentos adaptados para outros contextos funcionais. Quando se observam filhotes de gatos e cachorros, por exemplo, notamos comportamentos típicos de agressão, defesa, fuga ou predação, dirigidos para os irmãos, para a mãe, para objetos inanimados ou para seres humanos. Por certas características das seqüências comportamentais, no entanto, podemos perceber que simulam o comportamento adaptativo correspondente. Bjorklund e Pellegrini (2001) ressaltam a falta de propósitos imediatos observada no comportamento lúdico - fato que confere ao brincar um caráter de predominância dos meios sobre os fins.

Vários estudiosos ocuparam-se em destacar características que diferem o brincar da correspondente atividade não lúdica ou "séria". Sylva, Bruner e Genova (1978), mais preocupados com a função cognitiva do jogo, caracterizaram o brincar nos seguintes termos: (1) “A essência do brinquedo é a dominância dos fins sobre os meios... o processo de brincar é mais importante que o resultado" (pág.244). Tanto em seres humanos quanto em não humanos, o brincar reúne unidades ou séries de comportamentos em seqüências comportamentais nãohabituais; (2) o brincar ocorre num "modo simulativo". Tanto um babuíno como uma criança 
podem simular ataques nas brincadeiras. $\mathrm{O}$ brinquedo, nesse caso, possibilitaria a diminuição do risco de fracasso; (3) uma terceira característica da atividade lúdica é a possibilidade que oferece de moratória para a frustração. Um obstáculo que seria intransponível para a solução de um problema na vida real torna-se facilmente contornável na situação lúdica; (4) a quarta característica do brincar seria a liberdade da atenção, a abertura para a estimulação do ambiente e o convite para o reconhecimento de todas as possibilidades de um evento; (5) como quinta característica do brincar, os autores apontam sua natureza voluntária, de comportamento autoiniciado. Sylva et al. (1978) concluem que o brincar, por ser de baixo risco e reduzir a frustração, é uma atividade que se auto-sustenta por muito tempo. $\mathrm{O}$ animal com uma rica história de ludicidade preparar-se-ia para resolver problemas de modo mais organizado e flexível.

Fagen (1981), analisando listas de características atribuídas à brincadeira por nove autores que propuseram caracterizações do brincar, destaca que há apenas três aspectos distintivos comuns em todas: (1) os comportamentos que ocorrem na brincadeira são semelhantes, mas não idênticos em forma aos que ocorrem em padrões adultos em contextos funcionais correspondentes e uma simples seqüência lúdica pode incluir fragmentos de vários contextos funcionais. Dois filhotes de raposa, brincando de luta, apresentam comportamentos semelhantes aos agonísticos - sem, porém, intenção de infligir danos ao parceiro - entremeados por sequiências de atos predatórios, sem a conseqüente predação; (2) a forma dos comportamentos na brincadeira difere da que se apresenta no correspondente contexto funcional, na medida em que os atos lúdicos são exagerados; (3) as sequiências lúdicas diferem das não lúdicas porque os comportamentos são, com maior frequiência, repetidos no brincar. Fagen acrescenta dois pontos que foram incluídos nas listas de três autores: a) as sequiências lúdicas têm uma ordem mais variável de atos do que os comportamentos correspondentes em contexto funcional; b) faltam às seqüências lúdicas os atos consumatórios e as conseqüências biológicas dos equivalentes comportamentos não lúdicos.

Fagen (1981) salienta que o brincar pode também ser definido, num contexto social, por um conjunto de convenções que tornam a interação recíproca e agradável. Para nos certificarmos de que um animal está brincando, acrescenta o autor, é necessário prestar atenção às mensagens que ele manifesta. Isso é válido para primatas e carnívoros, cujos sinais de brincadeira são semelhantes aos dos humanos. A face com aparência lúdica (play-face), relaxada, com "sorriso" largo ou boca aberta é observada em vários tipos de brincadeiras de primatas e de carnívoros. 
Embora, como qualquer outra categoria molar de comportamento, o brincar seja de difícil conceituação - inclusive porque envolve comparação com outras grandes categorias comportamentais -, é possível defini-lo quando se identificam a espécie estudada e o tipo de brincadeira focalizada. É importante que, ao conceituarmos alguma forma de brincadeira, tenhamos clareza dos aspectos que estão sendo considerados. Fagen (1981) sugere que observemos alguns critérios para a categorização comportamental do brinquedo, relacionados a seguir.

Forma - Utilizando esquemas estruturais, podem-se reconhecer comportamentos lúdicos pela presença ou ausência de atos comportamentais singulares ou pela forma peculiar, orientação, duração ou intensidade de ações que também ocorrem em outros contextos.

Causação - As causas do comportamento incluem contextos, situações, estímulos eliciadores, inibidores e concluidores, motivação e fatores causais ligados ao desenvolvimento tanto numa longa seqüência de história de vida, como numa escala mais curta de uma particular seqüência de comportamento.

Função - Conquanto a função adaptativa da brincadeira não seja tão óbvia quanto a de sistemas como os de alimentação, de luta, de predação ou de acasalamento, certas suposições a respeito da função do brincar podem predizer com sucesso muitos aspectos da estrutura social e temporal da brincadeira.

Propósito - Muito embora incluir propósito ou motivo para o comportamento possa colocar os cientistas numa posição de subjetividade ou de falta de rigor, atualmente muitos filósofos advogam a validade do emprego desse esquema conceitual. Pode-se, assim, considerar que, na brincadeira de luta entre dois animais, um não tem a intenção de ferir o outro.

Definições evolucionárias - O comportamento altruístico e cooperativo, por exemplo, aumenta a competência de um parceiro muitas vezes às custas da própria aptidão do animal que o apresenta. O altruísmo atravessa as linhas funcionais e causais, mas pode ser entendido numa perspectiva evolucionária mais ampla como vantajoso para a sobrevivência e reprodução de determinada espécie em certos contextos e condições de adaptação. Ou então, como interpretam Charlesworth (1996) e LaFreniere (1996), existem mecanismos psicológicos universais que beneficiam o comportamento egoísta nas relações entre pares e esses mecanismos podem favorecer tanto a cooperação quanto a competição

Finalmente, Fagen (1981) dá sua definição do brincar: "Vejo o brincar como comportamento que funciona para desenvolver, praticar ou manter habilidades físicas ou cognitivas e relações sociais, incluindo tanto táticas quanto estratégias, através da variação, 
repetição ou recombinação de subseqüências funcionais de comportamento deslocadas de seu contexto primário" (pág. 65).

Consideramos particularmente profícua a utilização dos critérios de Fagen (1981) em nosso trabalho, em que lidamos com vários tipos e aspectos das brincadeiras e em que procuramos relacioná-los com condições mais amplas do contexto das crianças, seja em sua inserção no grupo de companheiros, seja em seu lugar dentro do universo sociocultural.

\subsection{Significado funcional da brincadeira}

Não há dúvida de que comportamentos tão freqüentes na infância de vários animais tenham sido selecionados em virtude de seu valor funcional para a sobrevivência dos indivíduos e das espécies. Não se pode ignorar, também, que haja custos no brincar. O gasto energético é considerável e o animal se expõe a riscos constantes (Fagen, 1981; Smith, 1982). Sabe-se, por exemplo, que a maior causa de mortalidade entre filhotes de leões são ataques de machos adultos. Mesmo assim, leõezinhos arriscam-se a provocá-los com brincadeiras. Na espécie humana, as crianças, não fossem os cuidados dos adultos, poderiam machucar-se seriamente e com frequiência, pois estão sempre testando seus limites e enfrentando novos obstáculos. Em atividades livres, estão sempre pondo à prova suas habilidades: trepando cada vez mais alto, balançando-se cada vez com maior intensidade, testando seu equilíbrio em gangorras, em superfícies estreitas, envolvendo-se em brincadeiras de luta, etc. (Figura 3.1).

Segundo Smith (1982), os custos da brincadeira são claros e imediatos, mas os benefícios, conquanto devam exceder os custos, são retardados. O brincar faz parte do repertório de espécies com um período prolongado de imaturidade protegida - o que minimiza os custos e um período de vida longo - o que maximiza os benefícios. Os benefícios da atividade lúdica devem refletir as funções para as quais o brincar foi selecionado no decorrer da história de evolução da espécie. Smith relaciona as seguintes funções da brincadeira animal: (1) treino físico; (2) aprendizagem de habilidades sociais competitivas, como as de luta, de predação e de esquiva; (3) aprendizagem de habilidades sociais não-competitivas, como vinculação social, aprendizagem de postos sociais, de habilidades sociais complexas e de comunicação social; (4) aprendizagem de habilidades cognitivas, como as de uso de instrumentos e a aquisição de habilidades cognitivas generalizadas e inovadoras. $\mathrm{O}$ autor considera as duas primeiras funções 
como benefícios diretos do brincar de mamíferos, uma vez que os indivíduos não teriam outras maneiras de treinar habilidades relacionadas a ataque, predação e esquiva, a não ser através da brincadeira. Avalia como indiretos os demais benefícios, visto que os indivíduos teriam outros contextos em que treinar as habilidades sociais e cognitivas. Observa que essas funções podem ter sido úteis em nosso ambiente de adaptação evolucionária, mas que, atualmente, há outras maneiras de exercitar essas mesmas habilidades na infância.

Bjorklund (1997) vai além de Smith propondo a idéia - mais divulgada e aceita atualmente - de que alguns comportamentos da infância não são preparação para a função adulta, tendo sido delineados para adaptar a criança a seu ambiente presente. Algumas formas de comportamento, como é o caso do brincar, teriam sido selecionadas por seu valor imediato de sobrevivência. Consideramos, de acordo com Bjorklund e Pellegrini (2000 e 2001), que há pressões seletivas distintas em diferentes períodos da ontogênese e que algumas características das crianças têm um valor adaptativo num dado momento de sua história de vida e não na preparação para a vida adulta. Acreditamos que aspectos das interações sociais entre crianças abordados no presente trabalho, sejam no conflito, sejam na brincadeira, mostram-se inteiramente compatíveis com uma explicação da função adaptativa de alguns comportamentos infantis durante o determinado momento da ontogênese em que ocorrem, embora, secundariamente, possam trazer benefícios para a adaptação do ser em desenvolvimento em fases posteriores da vida.

Nas interpretações evolucionárias, devemos relembrar dois pontos: 1) os comportamentos adaptativos foram selecionados, não para a sobrevivência na cultura moderna, mas sim no ambiente de adaptação evolucionária; 2) nem todos os comportamentos contemporâneos foram selecionados na evolução: alguns são meramente o subproduto de outras adaptações ou conseqüências necessárias do crescimento físico.

Examinamos minuciosamente benefícios da brincadeira simbólica na dissertação de mestrado (Morais, 1980), havendo grande concordância com as mencionadas por Smith (1982): treino de atividades e de papéis adultos e da linguagem empregada nesses papéis; desenvolvimento da adoção da perspectiva do outro - necessária para a percepção de sentimentos, de intenções e do papel dos parceiros de interação; compreensão da complementaridade de papéis sociais; treino na inversão de papéis e na flexibilidade de comportamento; percepção das pistas sociais, inclusive sinais de brincadeira, de manipulação e de enganação; apreensão de normas, valores e crenças culturais. 
No caso específico da atividade lúdica humana, principalmente da brincadeira de faz-deconta, achamos impossível ignorar sua função cognitiva e emocional. Vários estudos voltados para o ganho cognitivo da brincadeira (Fein, 1982; Sylva et al., 1976) têm demonstrado que brincar tem resultado semelhante, quando não superior, ao do treino em tarefas de solução de problemas. Pesquisadores da teoria da mente (theory of mind) têm dado à imaginação da criança um papel central em sua habilidade de prever e de explicar comportamentos humanos: ao brincar imaginativamente, ela se coloca no lugar de outro, assumindo que o estado psicológico que resulta de sua simulação corresponderia à experiência real da outra pessoa. Taylor e Carlson (1997) encontraram, em um estudo com crianças três a quatro anos, fortes evidências de que há relação entre o desenvolvimento da teoria da mente e o brinquedo imaginativo. As observações dos estudiosos da teoria da mente remetem-nos aos benefícios cognitivos, sociais e emocionais da brincadeira de faz-de-conta.

Do ponto de vista dos benefícios emocionais, podemos constatar a função retaliativa e compensatória da brincadeira, que funcionaria de forma semelhante à sugerida por diversos psicanalistas. Dentre eles, mencionamos Peller (1952/1971) que advoga que a criança experimenta ativamente na brincadeira o que vivencia passivamente na realidade. Assim, ela pode tornar-se a mãe ou a professora que pune, o "bicho" que a assusta ou o pai que se omite. Freud (1920/1968) assinalou a importância do brincar na elaboração de situações traumáticas e de conflito emocional. Pelo princípio da compulsão à repetição, a criança reviveria, no brincar, situações que a perturbam emocionalmente, até conseguir superá-las e dominá-las. Migliavacca (2003 e 2004) trata da importante função dos mitos como formas de explicar o que é desconhecido, de dominar o medo do incontrolável e de trazê-lo para um campo familiar.

Supomos que os contos de fada, as narrativas imaginárias e as brincadeiras de faz-deconta, embora sem a dimensão extraterrena do mito, também preencham essa função para a criança. Se esses atos simbólicos não podem contribuir para elucidar os mistérios mais insondáveis da existência humana, ajudam na elaboração de fortes e inexplicáveis emoções. Cito como exemplo a simulação de morrer, componente muito freqüente nas brincadeiras de luta e de perseguição, mas magistralmente ilustrativo da tentativa de entender a morte no caso de uma menina observada numa instituição filantrópica:

Ta deita-se na gangorra como um morto no caixão, dizendo: "estou morta". No mesmo dia, representa várias vezes a mesma cena em diversos lugares, repetindo: "estou morta, vou com Jesus".

A importância das brincadeiras para o desenvolvimento das habilidades sociais dá-se em vários níveis. A inversão de papéis permite que os parceiros experimentem os dois lados da 
interação. Nas brincadeiras de luta, por exemplo, não são utilizadas técnicas perigosas e as mais violentas são inibidas. Em brincadeiras de animais, comenta Fagen (1981), o mais forte usa apenas parte de sua força para não lesar o outro. As relações de dominação desvanecem na brincadeira: um animal subordinado pode caçar e imobilizar um dominante. Não é diferente nas brincadeiras turbulentas dos humanos. Nas atividades lúdicas, as conseqüências das ações são minimizadas e os limites podem ser testados numa situação mais protegida.

Conquanto tenhamos visto várias funções do brincar, a síntese apresentada por Brown (1998) proporciona uma visão mais abrangente, ao evidenciar sua importância como elemento organizador, integrador e reparador da experiência. Os relatos apresentados pelo autor das dificuldades (algumas muito sérias) reveladas na vida adulta por pessoas que não brincaram, bem como a volta do brincar como indício de recuperação de crianças doentes indicam-nos sua importante função estabilizadora. Semelhantemente ao humor e à atividade criativa, o brincar é uma experiência prazerosa que não depende totalmente do ambiente para acontecer (embora seja favorecida por ele). Dá-se em uma zona transitória (Brougère, 1998), em que é possível não se arriscar muito, em que as penalizações são mais simbólicas do que reais. Embora não haja evidências neurofisiológicas para afirmarmos categoricamente o que se segue, como propõe Brown, é possível que, de forma análoga ao sonho e ao sono, o brincar funcione como um super-organizador da experiência, como um estabilizador para novas capacidades adquiridas, como uma alternativa à rigidez de padrões, que favorece a sobrevivência.

\subsection{Classificação das brincadeiras}

Desde Groos (1901/1976), têm sido várias as tentativas de classificação dos jogos e brincadeiras humanas. Groos utilizou-se do conteúdo para diferenciar os jogos, chegando à seguinte categorização: a) jogos de experimentação ou de funções gerais, correspondentes aos jogos sensoriais (assobios, gritos), jogos motores (jogo de bola, corridas), jogos intelectuais (imaginação, curiosidade), jogos afetivos e exercícios da vontade (jogos de inibição, como se sustentar numa posição difícil pelo maior tempo possível); b) jogos de funções especiais constituídos pelas brincadeiras de luta, perseguição, cortesia, imitação, jogos sociais e familiares.

Bühler (1946) sugere uma classificação estrutural, dividindo os jogos infantis em cinco grupos: jogos funcionais (ou sensório-motores); jogos de ficção ou de ilusão; jogos receptivos (ver imagens, ouvir histórias); jogos de construção; jogos coletivos. 
Piaget (1945/1975) critica a categorização de Groos, demonstrando o quão difícil é classificar, dentro do quadro proposto por esse autor, não só o grande número de casos intermediários, mas também os jogos clássicos, como o de bola de gude. Colocando restrições também à classificação de Bühler, propõe três grandes estruturas que caracterizariam os jogos infantis: o exercício, o símbolo e a regra, sendo os jogos de construção a transição para a conduta adaptada. Piaget estabelece, então, sua classificação para os jogos: (1) jogos de exercício sensoriais e motores - compreendem os que exercitam predominantemente os sentidos - como repetir sons, palavras, balançar-se e equilibrar-se - e os que empregam movimentos amplos e locomotores, como correr pular, saltar e trepar; (2) brincadeira simbólica - consiste em tratar pessoas, animais ou objetos com um significado diferente do que lhes é atribuído no contexto habitual; (3) jogos de construção - são aqueles em que a criança, utilizando-se de qualquer elemento, transforma-o em algo diferente: molda, empilha, enfileira, encaixa, etc; (4) jogos de regra - correspondem às brincadeiras em que a regra prepondera, embora possa haver componentes sensório-motores ou de construção presentes. Entre esses, Piaget cita os jogos de memória, de dama, de bola de gude, de futebol e de esconde-esconde.

Parker (1984), adotando uma perspectiva psicoetológica, propõe a seguinte classificação para as brincadeiras e jogos: brincadeiras de contingência, brincadeiras simbólicas ou imaginativas, brincadeiras agonísticas e de regras, definidas a seguir.

Brincadeiras de contingência. As brincadeiras de contingência, que já são observadas em bebês no período sensório-motor (do nascimento aos dois anos de idade), baseiam-se na compreensão de que suas ações criam efeitos contingentes. Assumem duas formas: (1) brincadeiras de contingência social e (2) brincadeiras de contingência física.

Nas brincadeiras de contingência social (ex: esconder-se e tornar a aparecer rapidamente), o adulto responde aos sinais vocais, faciais e gestuais do bebê com estímulos lúdicos, como fazer cócegas ou esconder-se e reaparecer (peak-a-boo). Durante as brincadeiras de contingência social, o adulto e o bebê alternam papéis: o bebê sorri ou vocaliza ou ergue as sobrancelhas; o adulto responde fazendo cócegas ou conversando; o bebê repete a ação, etc. (Bruner \& Sherwood, 1976). Parker (1984) considera que brincadeiras desse tipo são as primeiras manifestações do esquema de revezamento, que é característico das conversas posteriores, do faz-de-conta e dos jogos de regras, sendo provável que representem adaptações para praticar o esquema vital de revezamento. O esquema de revezamento está presente em toda interação humana a partir das primeiras semanas de vida. Aparentemente, é motivado e 
reforçado pelo prazer associado à capacidade de produzir respostas contingentes nos outros e de responder contingentemente a eles.

Brincadeiras simbólicas ou imaginativas. Ainda antes de serem capazes dae emitir as primeiras verbalizações com duas ou três palavras, as crianças pequenas imitam atividades diárias simples como dormir, comer, viajar, etc. À medida que se desenvolvem e se tornam mais competentes do ponto de vista lingüístico, representam cenas ainda mais longas e complexas da vida cotidiana.

Brincadeiras agonísticas. Segundo Parker (1984), o termo agonístico vem da palavra grega para luta: agõn. Os etólogos têm usado o termo para incluir brincadeiras de luta, de perseguição e de fuga, denominado-as também de brincar de luta ou de brincadeira turbulenta (Smith, 1988). Essa forma de brincadeira é caracterizada pelo exercício do corpo todo e pelas duas emoções recíprocas de ataque e de medo, além da motivação de contingência. $\mathrm{O}$ ataque lúdico motiva e é reforçado por surpreender, perseguir ou atacar o parceiro. O medo lúdico é estimulado por cair, fugir e submeter-se ao ataque. Ambas as emoções são prazerosas em intensidades moderadas, mas podem ser desagradáveis com o aumento da intensidade, transformando-se em ataque e medo reais.

As brincadeiras agonísticas começam com as atividades lúdicas dos pais de cutucar, bater, rodopiar e de fazer cócegas. À medida que adquirem mobilidade, as crianças começam a solicitar ativamente esses ataques lúdicos e a tomar a iniciativa. Elas também buscam ativamente excitação em balanços e outros equipamentos de playground.

Jogos de regras. Parker (1984) diferencia brincadeiras de jogos. Jogos seriam formas particulares de brincadeira, que envolvem a ritualização de papéis e a representação de cenas previsíveis e pré-determinadas. Nos jogos, as seqüências imprevisíveis da brincadeira são transformadas num ciclo repetitivo de ações, com início, meio e fim. Em conjunto com esse processo, a alternância informal de papéis característica da brincadeira é transformada em alternância da vez no jogo. Os jogadores têm ainda que conceber da mesma forma o cenário e suas regras.

Categorização usada no presente estudo. É difícil encontrarmos uma classificação plenamente satisfatória, uma vez que muitas funções e estruturas estão imbricadas e se sobrepõem nos diversos tipos de brincadeira. Contudo, podem-se isolar fatores preponderantes. À tipologia de Parker (1984) podemos acrescentar as brincadeiras sensório-motoras (que não necessariamente envolvem um componente de contingência) e as brincadeiras de construção, 
que se assemelham ao trabalho adaptado - categorias que foram introduzidas por Piaget (1945/1975) e excluídas pela autora. Classificação semelhante à utilizada no presente estudo foi empregada por Morais (1980) e Morais e Otta (2003a). Embora Parker (1984) tenha assinalado diferentes motivações para as brincadeiras de contingência social (impulsionadas pelo prazer de provocar reações contingentes nos outros e de responder a eles contingentemente) e para as brincadeiras agonísticas (motivações de ataque, medo e de contingência), quando nos detemos na análise das duas, percebemos que ambas denotam forte presença do componente de contingência social, ou seja, grande parte do prazer e da sustentação da brincadeira se dá pela reação provocada no outro. Neste trabalho, em vez do termo brincadeira agonística, utilizaremos a expressão brincadeira turbulenta (rough and tumble), introduzida anteriormente à proposta de Parker (Blurton-Jones, 1974/1976) e mais amplamente utilizada e consagrada para denominar o mesmo fenômeno.

Se, nas brincadeiras de contingência social simples, há um intercâmbio prazeroso, freqüentemente acompanhado de contato físico, nas brincadeiras turbulentas, a criança, além de provocar ludicamente a reação do outro, simula agressão. Da mesma forma, na zombaria - em que há elementos de hostilidade encoberta e de brincadeira, o que a torna uma atividade predominantemente ambígua -, a motivação de contingência está presente, na medida em que a criança provoca reações a seu comportamento não só no alvo da zombaria, como também nos companheiros que a presenciam. Endossamos a afirmação de Georgesen, Harris, Milich e Young, (1999), segundo a qual a mensagem de humor do desafio social é, muitas vezes, mais dirigida aos que assistem ao diálogo ou à cena do que aos próprios interlocutores.

Adotaremos, portanto, a seguinte categorização, que se encontra definida e exemplificada no sexto capítulo: (1) brincadeiras de contingência física; (2) brincadeiras de exercício sensório-motor ou físico; (3) brincadeiras de contingência social - não turbulentas e turbulentas; (4) brincadeiras simbólicas ou imaginativas ou de faz-de-conta; (5) brincadeiras e jogos de construção; (6) jogos de regras (Figura 3.2). Dado o caráter intermediário e ambíguo da zombaria, que se situa entre a brincadeira e o conflito, as provocações serão discutidas em separado no capítulo seguinte. 


\subsection{Brincadeiras de contingência social}

Destacamos as brincadeiras de contingência social, pois elas serão, juntamente com o conflito e com a zombaria, objeto de estudo mais detalhado no presente trabalho. Embora as brincadeiras turbulentas (BTs) tenham dado margem a muitas investigações (Pellegrini, 1993, 1995; Pellegrini \& Smith, 1998; Smith, 1988), desconhecemos estudos que tenham se dedicado à investigação das brincadeiras de contingência social não turbulentas entre coetâneos. Encontramos pesquisas de brincadeiras desse tipo apenas entre pais/mães e filhos. Como exemplos, destacam-se os trabalhos de Bruner e Sherwood (1976) - que investigaram brincadeiras face-a-face, de esconder e aparecer entre crianças e adultos (peek- $a$ boo) - e de Jimerson e Bond (2001) - que analisaram respostas contingentes de mães a seus filhos de três a seis anos de idade. Esses últimos verificaram que mães que pensavam que o conhecimento não é algo adquirível através de transmissão de uma pessoa para outra apresentavam menos respostas contingentes a seus filhos do que aquelas que acreditavam que o conhecimento é algo que pode ser recebido e transmitido.

Como, em relação às brincadeiras de contingência social entre companheiros, encontramos na literatura apenas estudos relativos às turbulentas, faremos uma breve revisão deles. Segundo Smith (1988), o interesse pela brincadeira turbulenta (BT) surgiu no final da década de 60 e no início da década de 70 com o trabalho dos etólogos humanos. Blurton-Jones (1974/1976) apresentou a primeira descrição moderna da BT. Esse autor caracterizou a BT por sete padrões de movimentos básicos, que tendem a ocorrer em conjunto: correr, perseguir, fugir, lutar, saltar com os pés juntos, bater no outro com as mãos abertas sem machucá-lo e rir. Smith diferenciou BT de briga real de acordo com os critérios reproduzidos no Quadro 3.1. Pellegrini e Smith (1998) conceituaram BT como comportamentos vigorosos, tais como perseguir, lutar, atacar, chutar e tombar, que pareceriam agressivos, caso não se apresentassem em contexto lúdico.

Alguns aspectos da BT, como a interação social recíproca, o nível de vigor físico e os agrupamentos simétricos de companheiros, teriam conseqüências benéficas para o desenvolvimento infantil (Pellegrini, 1995). Smith (1988) levanta as seguintes hipóteses funcionais para a BT: aprendizagem de habilidades predatórias ou de esquiva, aprendizagem de hierarquia social, ascensão na hierarquia social, promoção de cooperação e coesão sociais, aprendizagem de sinais sociais, aprendizagem de padrões complexos e variados de interação e desenvolvimento de flexibilidade comportamental. 
Pellegrini e Smith (1998) constataram que, entre pré-escolares europeus e americanos, a BT é responsável por cerca de 3 a 5\% das atividades lúdicas; entre seis e dez anos de idade, ela ocupa de 7 a $8 \%$ do horário de atividade livre das crianças; durante o período dos sete aos onze anos, ela se verifica em 10\% do tempo de recreio. De 11 a 13 anos, a frequiência de BT cai para $5 \%$, havendo decréscimo posterior durante a adolescência. Quanto ao gênero, os autores relatam que, em todas as culturas em que a BT foi estudada, os meninos superaram as meninas nessa atividade. Isso é verdadeiro inclusive para a maioria dos mamíferos, sendo a diferença entre os sexos maior em BT de contato do que em brincadeiras de perseguição e fuga.

Quadro 3.1. Critérios que discriminam BT de briga real em crianças (Smith, 1988).

\begin{tabular}{|c|c|c|}
\hline Critério & BT & Briga Real \\
\hline 1. Circunstâncias & $\begin{array}{l}\text { Não há conflito a respeito de } \\
\text { recursos. }\end{array}$ & $\begin{array}{l}\text { Frequientemente, há conflito a } \\
\text { respeito de recursos. }\end{array}$ \\
\hline $\begin{array}{l}\text { 2. Forma como o encontro é } \\
\text { iniciado por uma criança e tipo } \\
\text { de resposta }\end{array}$ & $\begin{array}{l}\text { Uma criança convida outra, que } \\
\text { pode recusar. }\end{array}$ & $\begin{array}{l}\text { Uma criança, freqüentemente, } \\
\text { desafia outra. Deixar de } \\
\text { responder significa intimidar- } \\
\text { se. }\end{array}$ \\
\hline $\begin{array}{l}\text { são facial e } \\
\text { tes durante o }\end{array}$ & $\begin{array}{l}\text { Cara de brincad } \\
\text { sorriso, ou expressão }\end{array}$ & $\begin{array}{l}\text { Olhar fixo, carranca, face } \\
\text { enrubescida, fazer bico ou } \\
\text { chorar. }\end{array}$ \\
\hline $\begin{array}{l}\text { 4. Número de participantes } \\
\text { envolvidos }\end{array}$ & $\begin{array}{l}\text { Dois, geralmente, mas podem } \\
\text { estar envolvidos mais. }\end{array}$ & $\begin{array}{l}\text { Raramente há mais de duas } \\
\text { crianças envolvidas. }\end{array}$ \\
\hline 5. Reação dos espectadores & $\begin{array}{l}\mathrm{O} \text { encontro atrai pouca atenção } \\
\text { por parte de crianças que não } \\
\text { estão participando. }\end{array}$ & $\begin{array}{l}\text { O encontro atrai muita atenção; } \\
\text { algumas vezes, um grupo de } \\
\text { espectadores se reúne em torno. }\end{array}$ \\
\hline$\overline{6 . \mathrm{Aul}}$ & $\begin{array}{l}\text { Uma criança maior ou mais } \\
\text { forte deixa de utilizar força } \\
\text { máxima. }\end{array}$ & $\begin{array}{l}\text { Normalmente não há auto- } \\
\text { incapacitação. }\end{array}$ \\
\hline 7. Cont & $\begin{array}{l}\text { Os participantes freqüente- } \\
\text { mente controlam a força. }\end{array}$ & $\begin{array}{l}\text { tenção ocorre em menor } \\
\text { u não ocorre. }\end{array}$ \\
\hline 8. Inve & $\begin{array}{l}\text { Há inversão dos papéis de } \\
\text { perseguidor e perseguido ou, ao } \\
\text { se engalfinharem, de quem fica } \\
\text { por cima ou por baixo. }\end{array}$ & $\begin{array}{l}\text { Geralmente, não se observa } \\
\text { inversão de papéis. }\end{array}$ \\
\hline $\begin{array}{l}\text { 9. Relação entre os partici- } \\
\text { pantes imediatamente após um } \\
\text { encontro }\end{array}$ & $\begin{array}{ll}\text { Os participantes, } & \text { geralmente, } \\
\text { ficam juntos em outra } \\
\text { atividade. }\end{array}$ & $\begin{array}{l}\text { Os participantes, geralmente, se } \\
\text { afastam. }\end{array}$ \\
\hline
\end{tabular}




\subsection{Diferenças culturais e de gênero nas brincadeiras}

Como vimos afirmando, a ludicidade da criança e sua tendência a estabelecer relações e vinculações com os companheiros fazem parte de um complexo adaptativo caracterizado pela vida sociocultural. A possibilidade de observar a brincadeira infantil tal qual ocorre em seu ambiente natural constitui um foro privilegiado em que se pode desvelar, na manifestação espontânea da criança, como se está processando seu desenvolvimento psicossocial, ao mesmo tempo em que se pode verificar como está sendo sua inserção na cultura e como essa se manifesta em suas atividades lúdicas. Embora o brincar seja reconhecidamente um comportamento universal da criança, como amplamente desenvolvido por diversos autores, jogos e brinquedos estão marcados pela identidade cultural e por características sociais específicas de um grupo social (Bichara, 2002; Bornstein, Haynes, Pascual, Painter. \& Galperin, 1999; Brougère, 1998; Carvalho \& Pontes, 2003; De Conti \& Sperb, 2001; Eibl-Eibesfeldt, 1989; Farver, Kim, \& Lee-Shin, 2000; Göncü, Mistry \& Mosier, 2000). A organização familiar, as condições de vida, os meios de subsistência influenciam diretamente as atividades lúdicas da criança. Chamemos de zona lúdica ${ }^{*}$ o espaço em que ocorre o brincar, constituído pelos seguintes elementos: o espaço físico propriamente dito, com suas dimensões e conteúdo, o espaço temporal, com o tempo dedicado à brincadeira (Friedmann, 1992), o indivíduo com suas experiências, seus recursos, suas motivações e as pressões e condições sociais que o cercam.

Pode-se falar de um espaço lúdico físico específico: dependendo do tipo de sociedade em que vive - rural ou urbana -, a criança pode ter campos, praias, ruas, matas para percorrer ou limitar-se a um pequeno quadrilátero, como ocorre na periferia das grandes cidades brasileiras. Nessa zona lúdica, podemos incluir todas as variáveis que influem no brincar das crianças: acesso à televisão (e tipos de programas a que assistem) e aos meios eletrônicos (internet, jogos computadorizados); disponibilidade de diferentes tipos de brinquedos; atitudes dos pais e de outros familiares com relação ao brincar (valorização/ desvalorização, liberdade/restrição para brincar); presença/ausência de irmãos (mais novos/mais velhos) e amigos com quem brincar; representações sociais coletivas (Berger \& Luckmann, 1966/1999; Brougère, 1998; Nicolopoulou \& Weintraub,1998) - que dizem respeito não só à brincadeira e às formas de brincar, mas à visão e à expectativa que se tem da criança, do adolescente e do adulto numa determinada sociedade. Como consideram Carvalho e Pontes (2003), a cultura infantil, da qual fazem parte suas atividades lúdicas, não só é influenciada pela cultura adulta, mas também a

\footnotetext{
* Rabinovich (2003) refere-se a conceito semelhante como estrutura de oportunidades do brincar.
} 
influencia, o que coloca a brincadeira como importante agente de transmissão e de modificação cultural.

Brincadeira e cultura. A compreensão da co-evolução da cultura e da capacidade de sua aquisição requer que examinemos como a criança a aprende e a transforma. A mera exposição da criança aos grupos sociais já é uma importante forma de adquirir cultura. Como ponderam Tomasello, Kruger e Ratner (1993), pode-se considerar esse meio de aquisição de comportamento como aprendizagem imitativa, que se diferencia da instruída. Através dessa última, o aprendiz internaliza instruções da pessoa que ensina e as usa para regular suas funções cognitivas. Particularmente relevante, quando se estudam grupos de crianças brincando, é o tipo de aprendizagem que Tomasello et al. denominaram colaborativa. Esses autores argumentam que a aprendizagem colaborativa não envolve, no sentido clássico, transmissão de conhecimentos de organismos maduros para imaturos, pois consiste na colaboração entre pares para construir algo novo, que não existia antes da interação. A aprendizagem através da colaboração pode também contribuir para a manutenção de tradições culturais, na medida em que o organismo imaturo se expõe a situações similares em sucessivas gerações. Nesse tipo de aprendizagem, as crianças envolvidas procuram entender a perspectiva do outro e aprendem por intermédio da relação com seus pares, de uma maneira simétrica e intersubjetiva. A aprendizagem colaborativa permite, pois, não só um processo de transmissão, mas, também e principalmente, de criação e de co-construção cultural. Ao brincar, a criança muda o significado das coisas e deve fazê-lo através de códigos e significados socialmente adquiridos; ao mesmo tempo, cria novos significados, que podem passar a ser compartilhados pelo grupo de brincadeira, tornando-se um novo elemento da cultura e da história do grupo (Morais \& Carvalho, 1994).

A socialização pressupõe a apropriação da cultura e o mecanismo pelo qual a criança dispõe dos elementos culturais passa, entre outras coisas, pela confrontação com imagens e com representações (Brougère, 1998). Cada cultura tem imagens consideradas expressivas e é, através delas, que a criança se manifesta. A brincadeira propicia a expressão peculiar de significados culturais individuais e coletivos, na medida em que é uma manifestação aberta da projeção de conteúdos socioculturais absorvidos pelas crianças.

Segundo Sutton-Smith (1986), a brincadeira livre se apresenta como forma de desenvolvimento e de expressão da criatividade infantil, uma vez que a imaginação lúdica domina os objetos e não o contrário. Em toda forma de expressão lúdica, a criança põe sua imaginação em ação (Vygotsky, 1984) e, como a imaginação é uma das janelas por onde se 
avista a cultura, procuramos, no presente trabalho, traçar um quadro geral das diversas formas de brincadeira observadas, para, depois, aprofundarmo-nos em algumas questões específicas.

Brincadeira e gênero. As diferenças de gênero estão intimamente relacionadas às culturais, uma vez que as representações sociais e significados partilhados dos papéis masculino e feminino são específicos de determinados grupos sociais. Relatamos, a seguir, algumas características típicas do brincar de meninos e de meninas, que aparecem em estudos realizados em diferentes realidades socioculturais.

Nicolopoulou e Weintraub (1998), estudando inúmeras narrativas infantis de crianças norte-americanas, encontraram que as histórias das meninas eram marcadas por conjuntos de personagens em relações harmônicas e estáveis, cujas atividades eram localizadas em lugares físicos constantes e específicos. Por sua vez, as histórias dos meninos eram caracterizadas por conflitos, movimentos, interrupções e, freqüentemente, por imagens extravagantes. Os autores concluem que o corpo das histórias de meninos e de meninas é conduzido por dois estilos narrativos altamente diferentes, que mostram o contraste dos modos característicos de representar a experiência e as imagens subjacentes de relações sociais e, correspondentemente, de conceber o self.

Diversos estudos sobre a brincadeira imaginativa com crianças euro-americanas (cf. Fein, 1981) e brasileiras (Morais \& Carvalho, 1994; Gosso, Morais \& Otta., 2002) revelam que os meninos brincam mais de temas fantásticos, de transportes, de luta, de perseguição e fuga e que as meninas, nas brincadeiras simbólicas, representam, predominantemente, atividades domésticas e de cuidados com o outro. Constata-se, em diferentes sociedades, que as crianças reproduzem, com bastante exatidão, os papéis de adultos de seu grupo cultural nas brincadeiras sociodramáticas (Gosso, Otta, Morais, Ribeiro \& Bussab, no prelo).

Como já mencionamos, um grande corpo de evidências demonstra que meninos e meninas preferem brincar com crianças do mesmo sexo e que, enquanto meninas preferem brincar em díades, meninos preferem fazê-lo em grupos grandes.

Martin e Fabes (2001) enfatizam que os meninos tendem a brincar mais em lugares públicos, com menor supervisão e menor proximidade do adulto do que as meninas. Smith (1988) e Pellegrini e Smith (1998) apresentam evidências de que, em inúmeras sociedades, as brincadeiras dos meninos são mais movimentadas, agitadas e turbulentas do que as atividades 
lúdicas das meninas, dados confirmados com crianças brasileiras por Souza e Rodrigues (2002) e por Gosso et al. (no prelo). Carvalho, Beraldo e Ortega (1993) relatam a preferência de meninos por brincar de luta e por jogar futebol. Essas mesmas autoras, porém, demonstram que as estereotipias de gênero diminuem com a idade e variam conforme a inserção cultural das crianças. Apesar de se verificarem diferenças relativamente constantes entre os gêneros em diversos estudos e em várias localidades, verifica-se, também, muita sobreposição entre as características e comportamentos das crianças de ambos os sexos, podendo-se afirmar que há mais diversidade na freqüência e no conteúdo de determinadas brincadeiras do que em sua forma.

Tendo em vista sua grande importância na determinação do comportamento e suas implicações socioculturais, o gênero, ao lado do grupo cultural, foi sempre levado em conta nas análises realizadas no presente estudo. Considerando-se que os papéis de gênero variam conforme os modelos de identidade, partilhado ou diferenciado (Nicolaci-da-Costa, 1988), e de acordo com a tradição cultural, supõe-se que se verifiquem algumas diferenças nas brincadeiras de meninos e de meninas dos grupos de São Paulo e de Ubatuba. Nas brincadeiras de faz-deconta, é provável que encontremos temas distintos nos dois grupos culturais em virtude de diferentes papéis que assumem homens e mulheres nas duas comunidades. Não há, entretanto, razões a priori para se supor que outros resultados sejam muito díspares daqueles encontrados em outros estudos.

Brincadeira e cultura brasileira. Considerando o vasto campo de pesquisas interculturais que o Brasil representa, podemos aquilatar que há um imenso potencial a ser explorado para estudos comparativos nos mais diversos domínios. Assim é também com o estudo da brincadeira, em que já existe um corpo de evidências que merece ser destacado (Carvalho \& Pontes, 2003), mas em que resta uma enorme potencialidade a ser desenvolvida.

Recentemente, um grupo de pesquisadores brasileiros, a maioria deles de orientação psicoetológica, tem-se dedicado a observar e a analisar brinquedos e brincadeiras do Brasil que ilustram nossa diversidade cultural. Bichara (2002 e 2003) estudou atividades lúdicas dos índios Xocó e de outras crianças que vivem às margems do Rio São Francisco. Magalhães, Souza e Carvalho (2003) contam-nos a respeito das piras (brincadeiras de pega-pega) de Riacho Doce, na periferia de Belém, no Pará. Rabinovich (2003) relata brincadeiras tradicionais dos "tempos dos avós" em diferentes contextos socioculturais. Santos (2003) descreve as brincadeiras de Novos Alagados, subúrbio de Salvador. Santos e Koller (2003) relatam as brincadeiras de 
crianças em situação de rua em Porto Alegre. Gosso et al. (2002 e 2003) compararam a brincadeira de faz-de-conta de crianças pertencentes a cinco grupos culturais: de uma aldeia indígena, de uma zona praiana e de três níveis socioeconômicos de zona urbana. Diversos trabalhos que relacionam brincadeira e modalidades interacionais (Carvalho \& Rubiano, 2004; Pedrosa \& Carvalho , 1995) e que abordam diferenças de gênero (Carvalho et al., 1993; Souza \& Rodrigues, 2002) foram, também, realizados com crianças brasileiras. Importantes colaborações têm sido feitas, igualmente, por pesquisadores brasileiros de outras linhas investigativas, como sociólogos, antropólogos, educadores e psicólogos de diferentes linhas teóricas (Friedmann, 1992; Oliveira, 1982; Nunes, 1999). Citar apenas alguns deles pode significar fazer injustiça com outros. Por essa razão, serão mencionados oportunamente no decorrer deste trabalho, quando o tema abordado for de interesse para nossas análises.

Os relatos de brincadeiras de crianças indígenas, como as Parakanã (Gosso e Otta, 2003), as A’uwe-Xavante (Nunes, 2002), as Mehináku (Gregor, 1982) e as Camaiurá (Moisés, 2003), têm demonstrado interessantes peculiaridades e a riqueza de brincadeiras tradicionais entre esses povos, sumarizadas por Gosso et al. (no prelo). Dentre as atividades lúdicas observadas nas comunidades indígenas, ressalta-se a abundância de jogos de regras - principalmente com mísseis, como bolas, arcos e flechas e dardos especiais -, de jogos ritualísticos - que reproduzem rituais coletivos - e de brincadeiras de faz-de-conta - em que as crianças representam papéis de adultos de seu grupo cultural. A liberdade com que são criadas as crianças indígenas e seu livre acesso a instrumentos adultos também se distinguem dos hábitos que se observam em crianças dos grandes centros urbanos - mais vigiadas e controladas pelos adultos, mais influenciadas pelos meios eletrônicos, pela mídia e pelo incentivo ao consumo de brinquedos industrializados.

Todos os trabalhos mencionados são iniciativas que, ao mesmo tempo em que resgatam nossas tradições e ilustram as peculiaridades regionais de nosso imenso país, demonstram aspectos universais do brincar infantil.

\subsection{Síntese}

A brincadeira é a principal forma de a criança se expressar e seu modo característico de expressar cultura. Envolve riscos e custos energéticos que, evidentemente, são superados pelos benefícios que acarretam. Considera-se que a brincadeira ocorre em uma zona transitória entre o 
imaginário e o real, em que é possível não se arriscar demasiadamente e em que as penalizações são mais simbólicas do que concretas.

Diversas são as funções preenchidas pela brincadeira do ponto de vista sensório-motor, cognitivo, emocional e social (Smith, 1982; Piaget, 1945/1975; Peller, 1952/1976). Tende-se, atualmente, a considerar que suas principais funções se referem a adaptações da criança em seus ambientes e contextos de desenvolvimento (Bjoklund, 1997). Brown (1998) sintetiza a importante função organizadora do brincar como elemento estruturante, integrador e reparador da experiência.

Neste trabalho, categorizam-se as brincadeiras, a partir de uma adaptação de critérios de Piaget (1945/1975) e de Parker (1984), em brincadeiras de contingência física, brincadeiras de exercício sensório-motor ou físico, brincadeiras de contingência social - não turbulentas e turbulentas -, brincadeiras simbólicas ou de faz-de-conta, brincadeiras e jogos de construção e jogos de regras. Embora as brincadeiras turbulentas tenham sido alvo de várias pesquisas, as de contingência social foram pouco estudadas. Por essa razão e por seu caráter contingente e relacional, semelhante ao do conflito e da zombaria, as brincadeiras de contingência social terão especial destaque neste trabalho.

Considera-se a existência de uma zona lúdica virtual, em que se incluem todas as variáveis envolvidas no brincar das crianças: acesso a meios eletrônicos e da mídia; disponibilidade de diferentes tipos de brinquedos; atitudes dos pais e de outros familiares com relação ao brincar; irmãos e amigos com quem brincar; representações sociais coletivas, práticas e significados partilhados.

Pondera-se que a cultura infantil, além de ser influenciada pela cultura adulta, pode também criar novos significados, que passam a ser partilhados nos grupos de brincadeira.. Salientando a importância de pesquisas interculturais, relacionam-se alguns estudos realizados em diversas comunidades brasileiras, inclusive indígenas, que vêm trazendo importantes elementos para a compreensão das atividades lúdicas e de sua interface com a cultura.

Substanciais diferenças de gênero tem sido encontradas nas brincadeiras de crianças em pesquisas nacionais e internacionais. De maneira geral, tais estudos mostram que as brincadeiras dos meninos são mais movimentadas e desorganizadas, ao passo que as brincadeiras das meninas são mais calmas, delimitadas em espaços territoriais mais restritos e mais estruturadas. Em brincadeiras de faz-de-conta, os meninos e as meninas desempenham papéis de homens e de mulheres de seu grupo cultural, reproduzindo, na brincadeira, o que observam na sociedade a 
que pertencem. As meninas tendem a simbolizar, predominantemente, atividades domésticas e de cuidados com os outros, enquanto os meninos tendem a desempenhar atividades fantásticas e de luta, perseguição e fuga.

A descrição de características dos grupos de brincadeira servirá também como referencial para compreender melhor as interações sociais das crianças e as disputas por recursos, que serão discutidas no próximo capítulo. 


\section{O JOGO SOCIAL: INTERAÇÕES, CONFLITOS E ZOMBARIA}

É inegável que as brincadeiras grupais, em todas as suas manifestações, são importantes meios de regulação interacional e de desenvolvimento do ajustamento social. Contudo, outros fenômenos que ocorrem paralelamente, dentro ou fora do contexto lúdico, evidenciam que os processos de regulação social estão longe de serem simples. Como observamos na dissertação de mestrado (Morais, 1980), as brincadeiras infantis são constantemente interrompidas por conflitos, discussões e desavenças, que demandam ajustes interacionais para que as atividades grupais tenham andamento. Dentre os fenômenos, processos e mecanismos envolvidos na regulação social, destacamos, neste capítulo, a cooperação e a competição - como fenômenos que estão na base da constituição e manutenção dos grupos e da disputa por recursos -, o conflito - como mecanismo regulador das interações - e a zombaria - como comportamento estritamente social, que se situa na fronteira entre o lúdico e o agressivo.

\subsection{O contexto interacional}

Supõe-se que a maioria das características únicas da cognição de primatas tenha advindo das exigências de adaptação à vida social através da cooperação, da competição, da enganação e da aprendizagem social (Bruner, 1990; Hinde, 1987; Lock, 2000; Tomasello et al.,1993). Assim sendo, a interação social é atualmente vista como constitutiva do desenvolvimento cognitivo e da interação com o mundo físico (Pedrosa \& Carvalho, 1995). Tomasello et al. (1993) afirmam que, no contexto social em que vive, "o homem desenvolveu habilidades sócio-cognitivas para entender o estado de seus co-específicos em termos de suas percepções, intenções, pensamentos e crenças, o que lhe permitiu adotar a perspectiva dos outros e comunicar-se intersubjetivamente com eles" (pág. 509). Simultaneamente, do ponto de vista afetivo, houve, na evolução humana, processos que favoreceram o aumento da vinculação afetiva entre pais e filhos e entre iguais, que, por sua vez, proporcionou as bases para o desenvolvimento cultural (Bussab, 2002).

A dependência física e a longa imaturidade da criança, sua disposição para o estabelecimento de relações com poucos adultos, a tendência à identificação como base da aprendizagem através de modelos e a ludicidade aparecem como componentes interligados de 
uma sistema adaptativo caracterizado pela vida sociocultural (Carvalho, 1989). O comportamento social tem, portanto, um papel central na formação e desenvolvimento de nossa espécie. Carvalho (1989) conceitua como social o espaço de informação construído por seres que têm a propriedade de sociabilidade, entendida como a propriedade de regular e de ser regulado por um co-específico.

Hinde (1987) salienta que a interação é um elemento básico para a análise do comportamento social e pressupõe que o foco desse comportamento está na regulação mútua que ocorre entre os indivíduos. Quando dois indivíduos interagem em sucessivas ocasiões, estabelece-se entre eles uma relação, em que estão envolvidos o controle e a regulação mútua. O conceito de relação assume, portanto, um caráter temporal e histórico. Nessa medida, "a relação tem - e é - uma história que está contida em cada interação, que, por sua vez, continua a constituí-la” (Carvalho, 1998, pág. 208).

O tema das interações e das relações interpessoais será constantemente retomado no presente trabalho, cujos principais objetos de estudo situam-se no âmbito das trocas sociais. Como já foi enunciado, supomos que, para melhor entendermos as interações que se estabelecem nos grupos infantis, o estudo intercultural mostra-se uma ferramenta preciosa.

\subsection{Cooperação e competição}

Cooperação e competição são fenômenos constantemente presentes na interação social, não só na vida humana como também na de outros animais. A despeito das claras vantagens de se viver em grupo e de coordenar ações com os outros, o fato de os recursos serem limitados leva a uma competição intragrupo e essa competição tem consequiências de longo alcance para o desenvolvimento humano (Hawley, 2000). Segundo LaFreniere (1996), a habilidade de equilibrar as tendências a competir e a cooperar é fundamental para a adaptação social de uma espécie, pois a cooperação pode ser essencial para criar a prole, para competir com outros grupos e para gerar recursos, enquanto o comportamento egoísta pode proteger os indivíduos da exploração e aumentar suas chances de sucesso reprodutivo. Dimensões ecológicas do grupo de companheiros - como estruturas afiliativas e de dominância e diferenças individuais em 
competência social, em capacidade cognitiva e na regulação e na expressão afetivas - podem operar para aumentar ou restringir a cooperação entre vários membros do grupo.

LaFreniere (1996) ressalta, ainda, a importância de dimensões como dominância social, enganação e afiliação no controle e distribuição de recursos. No caso das sociedades humanas, pode-se dizer que os recursos são gerados e distribuídos por sistemas de regras que beneficiam aqueles que estão em posição de controle. A agressividade pode freqüentemente caracterizar os membros menos dominantes, ou seja, os que não estão no controle de recursos. Isso é verdadeiro também para grupos de crianças, nos quais o comportamento agressivo não aumenta as chances de utilização de recursos, sendo uma característica comportamental que, muitas vezes, enseja rejeição por parte dos companheiros (Morais, Otta \& Scala, 2001). Considerando-se que a dominância social entre humanos está intimamente identificada com o controle dos recursos, é clara sua importância para a compreensão da cooperação.

Os laços afiliativos entre membros de uma unidade social estável poderiam dar a liga que permite que certos pares participem de atividades genuinamente cooperativas. Nessa medida, LaFreniere (1996) considera que as relações de amizade partilham algumas semelhanças funcionais com as relações de parentesco. Segundo o autor, políticas de reciprocidade e de amizade parecem ser a chave para compreender por que alguns grupos de companheiros podem cooperar e gerar recursos, enquanto outros não.

LaFreniere e MacDonald (1996) afirmam que há mecanismos psicológicos universais que beneficiam o comportamento egoísta nas relações entre pares e que esses mecanismos podem favorecer tanto a cooperação quanto a competição. Charlesworth (1996), por sua vez, assume que a cooperação deve ser vista como uma variante da competição e não como oposta a ela. Numa interação diádica de natureza cooperativa, infere-se que há competição, quando um dos parceiros obtém mais recursos que o outro. Da mesma forma, supõe-se haver competição, quando duas crianças cooperam para obter mais recursos que uma terceira. Charlesworth inclui, como variantes ou estratégias de competição, a enganação, a manipulação, a intimidação e a agressão, ao lado da cooperação. O objetivo dos que empregam essas estratégias seria adquirir recursos para a sobrevivência, para o crescimento e para a reprodução. $O$ autor propõe que o ideal para uma estratégia evolucionária estável seria uma composição das diversas táticas de competição, variando o peso relativo de cada uma delas de acordo com a natureza da tarefa e do comportamento daqueles que estão envolvidos em solucioná-la. Ressaltando as diferenças individuais, argumenta que os indivíduos variam em sua habilidade de competir por recursos nas 
interações sociais. Os recursos podem ser físicos (alimentação, abrigo ou território), sociais (cuidadores, companheiros, amigos) ou de informação. Recursos de um tipo (como dinheiro, propriedades) podem ser usados para adquirir outros.

Dada a natureza social de grande parte da competição por recursos, as habilidades de mostrar empatia pelos outros, de perceber o mundo através da perspectiva dos outros e de ajudálos a satisfazerem suas necessidades são meios importantes de receber em troca sua colaboração. Conseqüentemente, adquirir a habilidade de cooperar constitui uma importante tarefa do desenvolvimento.

Entre as estratégias de competição, Charlesworth (1996) aponta: ataque físico, ameaça verbal, coerção, zombaria, intimidação, adulação, apaziguamento, tirar partido de uma situação, mentir, distorcer, enganar, dissimular, ajudar, compartilhar e trabalhar com os outros. $\mathrm{O}$ autor encontrou que a estratégia mais eficiente para a obtenção de recursos, em grupos de crianças, é uma combinação entre ajudar os outros, dar ordens, manipular e enganar. Charlesworth presume ainda que, do ponto de vista evolucionário, pode-se supor que as desigualdades na aquisição de recursos durante a evolução hominídea tenham contribuído para a sobrevivência diferencial e para a formação do comportamento social humano. Grande parte do comportamento social humano, que resulta na aquisição e defesa de recursos bem sucedidas, inclui cooperar com os outros e, ao mesmo tempo, agir de forma egoísta, utilizando comportamentos perturbadores, como ameaçar e atacar. Charlesworth conclui com a afirmação de que a extensão da capacidade de combinar técnicas de cooperação e de competição da vida adulta para a infância, ao longo do tempo de evolução, foi necessária para dar conta da crescente sutileza e da flexibilidade na aplicação de tais combinações, solicitadas pelo aumento da complexidade social, resultante do papel crescente que a cultura passou a desempenhar na evolução humana.

Essas considerações preliminares a respeito da cooperação e competição constituem um pano de fundo para a compreensão dos conflitos interindividuais, que se tratam sempre, em última instância, de disputas por recursos, sejam eles alimentos, objetos, território, atenção, afeto ou controle social.

\subsection{Conflitos}

A história natural nos mostra que, quando os indivíduos vivem em grupo, recebem benefícios através da presença e da cooperação ativa dos outros na localização de comida, na criação da prole ou na detecção de predadores (isso vale para formigas, pássaros e homens). 
Entretanto, a vida em grupo também traz custos, como os advindos da exploração simultânea de recursos. Os custos indiretos são maiores, quando os indivíduos têm de coordenar suas atividades de forma a permanecerem juntos (Aureli \& de Waal, 2000).

Para manter os benefícios da vida em grupo, os indivíduos necessitam reduzir seus custos, diminuindo a competição e resolvendo os conflitos de interesses. Conseqüentemente, os mecanismos de administração de conflitos são componentes críticos da vida social de todas as espécies que vivem em grupo. De acordo com a teoria evolucionária, consideram-se os mecanismos de gerenciamento de conflitos como fenômenos naturais que funcionam para manter a integridade dos grupos e os benefícios associados a cada um de seus membros. $\mathrm{O}$ equilíbrio entre custos e benefícios é um aspecto universal das relações sociais estáveis. Os desequilíbrios, portanto, ameaçam a estabilidade. Ao competir por recursos, os membros do grupo devem, pois, não só levar em conta o valor do recurso ou o risco de danos, mas, também, a importância de seu relacionamento.

Mesmo quando a cooperação entre companheiros está bem estabelecida, não se espera perfeita harmonia e eqüidade nas transações relacionais, mas sim constante negociação e avaliação dos próprios custos e ganhos e dos benefícios e perdas dos outros. Nessas avaliações, os indivíduos estão predispostos a exagerar seus próprios custos e a minimizar seus ganhos e a diminuir os custos e a supervalorizar os ganhos dos outros (LaFreniere, 1996). As desigualdades, maiores ou menores, reais ou percebidas, provocam e alimentam conflitos sociais (Charlesworth, 1996). Tendo em vista que os indivíduos não se relacionam identicamente, os grupos sociais tornam-se arenas de disputa e de cooperação e, quando os interesses conflitam, aparentemente não há "melhor solução" (Lyons,1993; Tooby \& Cosmides, 1987). Os aspectos partilhados da cultura são o resultado de indivíduos negociadores. O poder diferencial e a habilidade de influenciar elementos culturais não é só propriedade das classes dominantes, mas uma constante em quase todas as interações. Diferentes contextos sociais criarão "culturas específicas da situação". Tal é o caso do grupo familiar e do grupo de companheiros.

Tomasello et al. (1993) relatam estudos que comprovam que as crianças que aprendem na interação com os companheiros não são as que agem ou brincam paralelamente, mas sim as que se envolvem com seus parceiros no sentido de planejar em conjunto, de responder às idéias dos outros, de pedir esclarecimentos e de discutir sua atividade conjunta. Na conversa simétrica, aprendem a analisar o pensamento e a perspectiva dos companheiros. Em situações de cooperação ou de conflito, surgem co-construções, em que os parceiros da interação fazem um esforço de intersubjetividade. Nesse contexto, um destaque especial deve ser dado ao conflito, que possibilita a confrontação entre diferentes pontos de vista. 


\subsubsection{Conceituação}

$\mathrm{Na}$ perspectiva adotada por Valsiner e Cairns (1992) - que consideram a interdependência entre o fenômeno e seu contexto e entre diferentes partes dos fenômenos -, o conflito, em sua conotação mais geral, é definido em termos do caráter da ligação entre as partes diferenciadas de um todo, ligação essa que pode embutir oposição entre as partes. Os autores exemplificam seu pensamento com a brincadeira harmônica de duas crianças que, a qualquer momento, pode transformar-se em briga, sendo que, ambos os estados - brincadeira e disputa podem indicar aproximação e afeto entre os parceiros de interação. Da mesma forma, conceitos antitéticos, como cooperação e competição, dependência e independência, deixam de ser mutuamente exclusivos para se tornarem coexistentes e interdependentes. Cada um dos conceitos em oposição depende do outro para sua existência e a eliminação de um leva à eliminação do sistema inteiro, do qual ambos fazem parte. Os opostos são inseparáveis na medida em que são partes funcionais de um todo interdependente. $\mathrm{O}$ todo existe devido à oposição entre as partes e cessa de existir quando a oposição é eliminada. Em síntese, se explicarmos o processo de desenvolvimento através de oposições (ou de conflitos), as partes em oposição do mesmo todo precisam estar relacionadas, de forma a levar a uma nova organização, em vez de acarretar o colapso do sistema.

Dentro da perspectiva do desenvolvimento, Valsiner e Cairns (1992) consideram a existência de dois tipos de conflito: o bom conflito - uma relação de oposição que leva à emergência de novos estados do sistema - e o mau conflito - o choque ou a guerra de opostos exclusivamente competitivos que devastam um ao outro, levando à extinção do todo de que fazem parte. O desenvolvimento ocorre, então, sob condições de relações interpessoais que são tanto harmoniosas quanto conflituosas. Embora essa seja uma apreensão do conflito em sua acepção geral, é compatível com a conotação mais específica de conflito interindividual, adotada no presente trabalho.

Conflitos interindividuais são definidos por Lyons (1993) como incompatibilidades entre expectativas, objetivos ou interesses de duas ou mais partes. Inferem-se incompatibilidades quando as ações ou demandas de uma parte sofrem, ao menos inicialmente, resistência ou oposição por parte de outra. O autor acrescenta que os conflitos sociais tendem a ser episódicos, começando com a incompatibilidade entre ações, objetivos e interesses de dois ou mais participantes e terminando quando o antagonismo é resolvido, ao menos temporariamente, através de alguma forma de acomodação, condescendência, submissão, ou desistência da oposição por parte de um ou de ambos os participantes. 
Shantz (1987) argumenta que o estado de conflito implica comportamentos ou objetivos incompatíveis e que o conflito se caracteriza por uma afirmação ou comportamento de oposição numa relação diádica. A autora constata que, para alguns pesquisadores, basta uma criança contrariar a outra para que se considere que um conflito foi estabelecido e, para outros, é necessário que a primeira persista em sua posição para se afirmar que um conflito foi instalado ou seja, para esses últimos, a oposição é necessária, mas não suficiente. Shantz considera que um conflito deve ser mútuo. Chama, porém, atenção para o fato de que há muitas definições de conflito, o que não quer dizer que apenas uma seja correta.

Laursen, Finkelstein e Betts (2001) definem conflitos como episódios sociais distribuídos no tempo e constituídos por uma série de componentes, que incluem discussões, oposições, resoluções e resultados. Farris (2000) adota a definição de conflito como a interação que se desenvolve a partir da oposição a uma solicitação para a ação, a uma afirmação ou a uma ação. As respostas negativas a oposições incluem recusas, discordâncias, negações e objeções. Um episódio de conflito começa com uma oposição - ou, nos termos de Maynard (1985), com uma afirmação ou ação questionável que se torna parte de uma disputa apenas se for contradita e termina com a resolução ou dissipação do desentendimento.

Encampamos, neste trabalho, a conceituação de Lyons (1993), a qual consideramos mais completa e operacional e incorporamos a ela o elemento de oposição adotado por Shantz (1987) e por Farris (2000), que nos ajudará na definição e análise dos episódios de conflito. Consideraremos que uma interação entre duas ou mais crianças é conflituosa a partir do momento em que alguma delas estabelece uma oposição verbal ou gestual à ação, ordem ou intenção de um(a) companheiro(a) envolvido(a) na situação.

\subsubsection{Funções dos conflitos}

A natureza essencialmente dialética do conflito - seja ele entendido em sua conotação ampla, ou no sentido empregado neste trabalho, de conflito interpessoal - leva-nos a concluir, com Shantz e Hartup (1992), que muitas funções diferentes, como cognição, entendimento social, emoção e relações sociais, são formadas ou transformadas pelo conflito: "é impossível, pensar-se a ontogênese sem conflito" (pág. 2) - afirmam os autores Nesse sentido, a maior parte 
das teorias do desenvolvimento são dialéticas, atribuindo ao conflito funções na ontogênese semelhantes àquelas exercidas na evolução social e cultural.

Segundo Mason e Mendoza (1993), o potencial destrutivo do conflito social teria presumivelmente contribuído para a evolução de maneiras de aliviar suas consequiências. Há uma série de comportamentos ritualizados entre os primatas que cumprem tal função, sinalizando intolerância, submissão, intenção amigável, reasseguramento, etc. Os conflitos podem também contribuir para a ordem social como força criativa e positiva.

A função dos conflitos para o desenvolvimento psicológico e para o fortalecimento de laços afetivos tem sido evidenciada por estudiosos das mais diversas linhas. A psicanálise reconhece, na resolução construtiva de conflitos intrapsíquicos, uma força que faz o ser humano evoluir em direção a níveis mais complexos de funcionamento psicológico. Dentro da perspectiva psicanalítica, Migliavacca (2004) nos fornece inúmeros exemplos da luta do ser humano para resolver seus conflitos nos mitos e nas tragédias gregas. Piaget (1970) hipotetizou que o desentendimento entre companheiros causaria conflito cognitivo, considerado pelo autor como o principal motor do desenvolvimento intelectual. Mason e Mendoza (1993) encampam a perspectiva de que o conflito é uma forma de socialização e um fato necessário para manter a integridade do grupo. Lorenz (1966) também salienta o papel dos conflitos como uma força na evolução e acredita que laços pessoais e afetivos, em muitos casos, surgem em decorrência de agressão intraespecífica.

Aspectos construtivos do conflito são ressaltados por vários autores, dentre eles, Lyons (1993), que expôs uma série de razões para não se considerar o conflito sempre como fator de ruptura e de destruição: (1) conflitos a respeito de meios para adquirir resultados mutuamente desejados são aspectos comuns das atividades cooperativas em primatas humanos e não humanos. Em espécies monogâmicas, por exemplo, em que pai e mãe criam a prole, os pais podem entrar em desentendimento quanto à melhor maneira de criar os filhos, mas, como ambas as partes têm o mesmo objetivo, o resultado pode ser positivo; (2) conflitos podem levar ao estabelecimento de regras, normas e sistemas de expectativas mútuas que servem para reduzir a incerteza e para promover coesão social nos relacionamentos interpessoais; (3) através dos conflitos, os indivíduos adquirem informações sobre os objetivos, interesses e valores dos outros. Momentos de conflito social podem prover oportunidades potenciais para negociar ajustamentos nos relacionamentos interpessoais a longo prazo. Hartup, Laursen, Stewart e Eastenson (1988) constataram que o comportamento social das crianças após um conflito não mudava consideravelmente. Verificaram que brincadeiras paralelas e cooperativas ocorreram 
após $82 \%$ dos conflitos e foram atribuídos às crianças estados afetivos positivos (16\%) ou neutros $(83 \%)$ mais do que negativos (1\%) após os conflitos. Lyons levanta a possibilidade de que, do ponto de vista evolutivo, não são os conflitos per se que seriam benéficos. Para o autor, os processos construtivos na resolução de conflitos é que preencheriam funções favoráveis à preservação de relações sociais importantes.

Têm sido particularmente esclarecedores os estudos que adotam abordagens baseadas no comportamento e nas conversas espontâneas das crianças (Dunn \& Slomkowsky, 1992). Os argumentos usados pelas crianças com seus pais e pares evidenciam seu entendimento dos sentimentos e das intenções dos outros, da compreensão de categorias de interação social, como amizade e autoridade, e das regulações sociais que estabelecem e mantêm os relacionamentos. É na questão da apreensão de regras sociais por parte das crianças que o estudo naturalista do conflito mostra-se particularmente interessante. As justificativas e desculpas que as crianças usam para conseguir seus próprios fins constituem uma fonte de dados para o entendimento de sua compreensão de regras sociais.

O conflito, além de ser um mecanismo importante para que a criança alcance a compreensão de regras e de organização social, é uma arena para a aquisição de competência comunicativa. Através do conflito, as crianças produzem organização social, criam alinhamentos políticos e realizam seus interesses práticos dentro de um conjunto de relacionamentos sociais (Farris, 2000). Laursen et al. (2001) apontam a importância do conflito para a aquisição de senso de justiça, para o domínio e regulação do afeto e para a definição da autonomia pessoal na criança. Entende-se, portanto, que o conflito pode funcionar de forma latente para alcançar e reproduzir estruturas sociais características de campos sociais mais amplos.

\subsubsection{Fatores que influenciam diferentes freqüências e soluções de conflitos}

Valor do relacionamento. Diversos autores (de Waal, 2000; Lyons, 1993; Verbeek, Hartup \& Collins, 2000) salientam a influência do valor do relacionamento ou da amizade sobre a resolução de conflitos. Verbeek et al. (2000) e Ljungberg, Wetlund e Forsberg (1999) relatam estudos que mostram que, nos conflitos entre amigos, as soluções tendem a ser mais integradoras do que destrutivas. A formação de amizade entre crianças pequenas parece estar marcada por uma dialética entre acordos e desacordos. Verbeek et al. e Ljungberg et al. 
constataram, ainda, que conflitos entre amigos são resolvidos de forma qualitativamente diferente daquela empregada em disputas entre não amigos. Esses autores verificaram que os conflitos entre amigos envolvem mais rompimentos e negociações, enquanto as desavenças entre não amigos tendem a ser resolvidos unilateralmente. Soluções integradoras são mais comuns entre amigos e as crianças geralmente permanecem próximas dos amigos após a cessação do desentendimento.

De Waal (2000) enfatiza que a possibilidade de reparação dos relacionamentos pode gerar aumento de conflitos: quanto mais reparável for a relação entre indivíduos que interagem constantemente, maior será a probabilidade de que surjam conflitos abertos entre eles. Isso se deve não só ao maior número de oportunidades para que ocorram disputas, em razão da maior freqüência de contatos entre indivíduos que se relacionam habitualmente, mas também ao fato de as conseqüências dos conflitos entre eles terem sido reparadas ao longo de sua história de vida conjunta.

Desenvolvimento. Laursen et al. (2001) também consideram que os encaminhamentos dados para as resoluções de conflitos podem ser moderados pelo tipo de relacionamento em que o desentendimento surge. Amigos e pares românticos fiam-se mais em negociação e menos na imposição e no rompimento para resolver discórdias do que conhecidos e irmãos. Amigos e pares românticos estão envolvidos num relacionamento voluntário, de forma que as resoluções de seus conflitos refletem o desejo de manter a ligação mútua. Entre conhecidos e pessoas cujo relacionamento tem menor importância para o indivíduo, não é necessário tanto investimento na relação: irmãos sabem que a continuidade do relacionamento está garantida, não necessitando, portanto, se preocuparem tanto com o rompimento. Laursen et al. também relatam que cenários de conflito hipotético evocam mais resoluções construtivas dos que aqueles eliciados por disputas reais; ou seja, a negociação pode ser o método preferido de resolução de disputas, mas a coerção é praticada com maior frequiência. Com o desenvolvimento, aumenta a negociação como meio de resolver conflitos entre pares e a coerção declina.

Cooperação/competição. Propondo que o estilo individual de manejo de conflitos variaria num contínuo entre cooperação e competição, Walters, Stuhlmacher e Meyer (1998) sugerem que a administração de conflitos pode ser caracterizada por orientações individuais em duas dimensões: assertividade e cooperatividade. A assertividade é definida como o grau de preocupação que o indivíduo mostra em relação aos próprios resultados numa disputa, enquanto a cooperatividade representa o grau de preocupação que uma pessoa tem com as conseqüências 
que o conflito pode ter para o outro. Esse modelo é conhecido como de dupla referência (dual concern). Nesse paradigma, o comportamento competitivo se apresenta quando um indivíduo é altamente assertivo e não cooperativo. Por sua vez, um indivíduo com uma orientação cooperativa pode ser considerado cooperativo-assertivo ou cooperativo-não assertivo. Indivíduos cooperativos-não assertivos têm uma atitude de auto-sacrifício em relação às necessidades dos outros. Indivíduos cooperativos-assertivos são considerados colaboradores. Há, finalmente, aqueles que não são nem cooperativos, nem assertivos e que evitam conflitos.

Tamanho do grupo. É provável que o potencial para o conflito aumente à medida que cresce o tamanho do grupo, não apenas por causa do número adicional de participantes, mas também pelas possibilidades de formação de facções e de coalizões (Mason \& Mendoza, 1993). Mason (1993) aponta a desagregação grupal em primatas como uma das importantes fontes geradoras de conflitos. Entre os fatores que desencadeariam a desorganização social, o autor menciona o aumento do tamanho do grupo a um ponto tal que a coordenação de deslocamentos e de outras atividades conjuntas entram em colapso.

Em outra perspectiva, que diz também respeito a diferenças de gênero, o tamanho do grupo é considerado como fator de influência nos conflitos. Como já mencionamos, Benenson et al. (2001) acreditam que a tendência de meninos a se envolverem mais em conflitos estaria associada a sua preferência por brincar em grupos grandes. Em grupos maiores, emoções causadas pela competição direta entre os indivíduos se dispersariam, propiciando-lhes algum grau de anonimato. Já as relações diádicas e mais próximas entre as meninas dificultariam a instalação de conflitos, uma vez que as disputas também teriam de ser enfrentadas de uma maneira direta e pessoal.

Duração e complexidade dos relacionamentos. Os processos dinâmicos envolvidos na formação e manutenção dos relacionamentos põem os indivíduos em situações em que seus interesses nem sempre coincidem. Mesmo em relacionamentos com nível de satisfação mútuo alto, surgem elementos de rejeição, resistência ou indiferença. Os primatas fiam-se extensivamente no conhecimento que têm de outros indivíduos para regular seu comportamento. A troca de informações é uma fonte essencial de organização da vida social desses animais, que freqüentemente se confrontam com a necessidade de ajustar-se àqueles com quem interagem, tendo, para isso, que levar em conta e conhecer o humor, características de personalidade, desejos, expectativas e intenções do outro. Esse processo de conhecimento intersubjetivo envolve questões tão complexas que dão margem a erros de interpretação e colocam, com 
relativa freqüência, problemas de relacionamento interpessoal de difícil solução (Mason \& Mendoza, 1993).

\subsubsection{Classificação dos conflitos}

Murphy e Eisenberg (1996) consideram que os conflitos são compostos de três elementos: as causas (investida física, disputa por objetos, controle interpessoal, agressão verbal e violação de regras), os objetivos (finalizar o conflito, manter o relacionamento, obter informações, invocar ações dos companheiros, conseguir vantagens ou um objeto) e as estratégias (agressões, contraposições verbais não agressivas, evitação e procura de intermediação de terceira parte). Shantz (1987) identifica cinco componentes do conflito: a questão (sobre o que é a discordância), a natureza da tentativa inicial de influenciar, a oposição, as estratégias usadas para efetuar a resolução e os resultados.

Verbeek et al. (2000) propõem analisar conceitualmente os conflitos em três fases seqüenciais: instigação, término e resultado imediato. A esse conjunto chamam de manejo ou de administração de conflitos. Introduzem uma importante forma de analisá-los, ao acrescentarem as noções de unilateralidade e de bilateralidade em seu manejo. O manejo unilateral caracterizase pelo oportunismo e pela falta de consideração pelas perspectivas e desejos do adversário, assim como pela subordinação. O manejo bilateral distingue-se pela adoção mútua da perspectiva do outro por parte de dois parceiros em interação e pela compatibilização de objetivos e de expectativas que se opõem. Quanto à instigação, os autores classificam os conflitos em morais e sociais. Em pré-escolares, por exemplo, as disputas por objeto são consideradas morais e os conflitos por regras de um jogo, sociais. As estratégias utilizadas para pôr fim a um conflito são consideradas unilaterais (afirmação de poder, coerção) ou bilaterais (negociação ou conciliação). Os resultados imediatos são considerados distributivos ou variáveis. Resultados distributivos são aqueles em que o ganho de uma criança representa a perda da outra. Resultado variável é aquele em que ambas as crianças vencem ou se beneficiam da situação.

Killen e Turiel (1991) apontam três tipos de resolução de conflitos em crianças de três a quatro anos de idade: (i) o assunto é abandonado ou (ii) a resolução é proveniente da criança ou (iii) provém do adulto. Laursen, Hartup e Koplas (1996) atribuem cinco formas diferentes à 
resolução de conflitos: submissão, que implica capitular; compromisso, que envolve negociação; afastar-se, que revela desviar-se da situação conflituosa; retirar-se, que reflete recusa em continuar na situação; resolução por terceira parte, que implica envolver um indivíduo não comprometido anteriormente. A nosso ver, a diferença entre afastar-se e retirar-se não é clara, implicando uma sutileza de intenção difícil de identificar.

Laursen et al. (2001), em sua meta-análise dos estudos de resoluções de conflito, agrupam-nas em três categorias: negociação (envolvendo intermediação de terceira parte e conciliação), rompimento (retirada, afastamento ou resfriamento da relação) e coerção (submissão). Laursen et al. (1996) afirmam que conflitos em que a coerção é o fator dominante implicariam comportamentos aversivos e emoções de raiva, resultando em afirmação de poder e em consequiências desiguais. A mitigação, que envolve compromisso, traz para a situação conflituosa resultados que facilitam a continuidade da interação. O compromisso tenderia a ocorrer com maior freqüência nas disputas entre amigos.

Ljunberg et al. (1999) classificam os comportamentos pós-conflito como afiliativos e não afiliativos. Consideram condutas afiliativas: convite para brincar, contato corporal afetuoso, pedido de desculpas, auto-ridicularização, mediação/ intervenção, oferta simbólica (ceder o lugar na fila ou o papel na brincadeira, por exemplo) e conciliação. Constituem exemplos de comportamentos não afiliativos: revanche, agressão redirigida e atividades deslocadas. Aureli e Smucny (2000), analisando a mediação da ansiedade no manejo de conflitos, propõem um modelo em que o meio físico, a experiência social e a qualidade do relacionamento atuam sobre a ansiedade, que surge a partir da oposição de interesses. Segundo os autores, conforme se processe o efeito de tais fatores sobre a ansiedade, um conflito pode resultar em evitação, submissão, tolerância ou reconciliação.

Farris (2000) adota uma perspectiva, mediante a qual, as respostas negativas ou de oposição, que ocorrem durante as disputas, são classificadas como: motivo ou justificativa, movimento contrário, temporização e evasão. Seriam reações à oposição: insistência, mitigação ou agravamento, explicação, contraposição, diretivas condicionais e acordos, além de comportamentos não-verbais, como ignorar e usar a força física.

A classificação que adotaremos no presente trabalho aproxima-se mais daquelas enunciadas por Shantz (1987), por Murphy e Eisenberg (1996) e por Verbeek et al. (2000), uma vez que esses autores consideraram diferentes fases do conflito. Nossa categorização, entretanto, 
contempla outras em aspectos que nos pareceram mais pertinentes: a definição de episódio de conflito assemelha-se à de Lyons (1993); acrescentamos à nossa análise as reações à negativa ou à oposição, conforme consideradas por Shantz (1987); incorporamos a concepção de desenlaces afiliativos e não-afiliativos, empregada por Ljunberg et al. (1999); adotamos a diferenciação entre estratégias coercitivas e assertivas não coercitivas, proposta por Walters et al. (1998); classificamos os desfechos com base no trabalho de Laursen et al. (2001) e os motivos dos conflitos, de forma semelhante ao apresentado por Mason e Mendoza (1993) e por Murphy e Eisenberg (1996). A concepção de conflito de Lyons, as adaptações dos motivos de disputas enunciados por Mason e Mendoza e dos desenlaces propostos por Laursen et al. são explicitadas a seguir.

Encampamos a definição de Lyons (1993), que entende que os conflitos sociais tendem a ser episódicos, começando com a incompatibilidade entre as ações, objetivos e interesses de dois ou mais participantes e terminando quando as discordâncias tenham sido resolvidas, ao menos temporariamente, através de alguma forma de acomodação, condescendência, submissão ou falta de oposição de um ou de ambos os participantes.

Consideraremos, neste trabalho, quatro momentos dos conflitos: (1) instigação, causa ou motivo; (2) estratégia de oposição; (3) forma de reação à oposição; (4) desenlace. Quanto à causa do conflito, nossa classificação assemelha-se à de Mason e Mendoza (1993), que relacionam como principais fontes de conflito: ocasiões em que dois indivíduos buscam a mesma coisa ao mesmo tempo e não podem ser simultaneamente satisfeitos; quando um dos indivíduos deseja algo que o outro é incapaz de satisfazer ou não deseja fazer; como conseqüência de ações ambíguas ou mal interpretadas. Classificaremos os desenlaces, a partir da categorização empregada por Laursen et al. (2001), como: negociação, intermediação de terceira parte, imposição, rompimento ou evitação (retirada, afastamento ou resfriamento da relação) e neutralização do conflito (virar brincadeira, mudar o foco da atenção). As definições encontramse mais detalhadas capítulo 6 .

\subsubsection{Diferenças culturais e de gênero em relação aos conflitos}

Diferenças culturais. Os dados encontrados em diferentes culturas confirmam que, desde cedo no desenvolvimento infantil, aparece a habilidade de competir usando vários comportamentos instrumentais. Esse é, portanto, um fenômeno praticamente universal. Observam-se também desigualdades notórias de acesso a recursos entre grupos de uma mesma 
cultura em diversas sociedades. Entretanto, comportamentos e estratégias empregadas para a obtenção de recursos estão presentes em diferentes graus e variam em estratos ou agrupamentos sociais distintos nas diversas culturas (Charlesworth, 1996; Crystal, Watanabe \& Chen, 2000; Eibl.Eibesfeldt, 1974).

Bonta (1997), numa extensa revisão das relações humanas em sociedades pacíficas, descreve culturas que são extremamente harmoniosas nos níveis intra e intergrupal, com pouquíssimos casos de violência e praticamente sem conflitos. A revisão de Bonta indica as mais variadas práticas sociais de criação, que inibem a competição e o conflito nas sociedades pacíficas: acessos de birra são ignorados a partir dos três anos de idade; aos quatro ou cinco anos de idade, as crianças são incentivadas a brincar silenciosamente, sem brigas; mães zombam dos filhos oferecendo o peito a outras crianças e divertindo-se com o fato de os próprios filhos afastarem os intrusos; pessoas mais velhas zombam de crianças que se mostram egoístas ou agressivas na relação com companheiros ou irmãos; adultos assustam as crianças com figuras amedrontadoras que as punirão, caso se mostrem assertivas ou agressivas; crianças são incentivadas a serem sensíveis às necessidades dos outros; colegas de classe encorajam uns aos outros para que alcancem um bom desempenho em benefício do grupo como um todo; os jogos cooperativos são incentivados; a modéstia e a humildade são estimuladas, enquanto qualquer manifestação de superioridade de uns em relação ao outros é punida. Diante de tais práticas que fortalecem a cooperação, podemos então perguntar: dados os benefícios apontados para os conflitos como fonte de fortalecimento dos laços sociais, o que ocorreria sem eles nas sociedades pacíficas? Existiriam vantagens para os conflitos apenas em sociedades competitivas? Essas questões, a nosso ver imbricadas com aspectos socioculturais e derivadas da própria natureza do conflito, poderão ser mais bem respondidas com o crescimento de estudos interculturais que utilizem a mesma metodologia de análise dos fenômenos observados.

Dada a importância do conflito na organização social e sua relação com os valores culturais mais amplos da macro-sociedade, esperam-se encontrar, e efetivamente se constatam, variações interculturais na incidência e forma dos conflitos. Corsaro (1994) verificou que crianças italianas se desentendiam mais do que as norte-americanas, comentando que os conflitos são um aspecto central da cultura infantil na Itália. O autor também constatou que crianças negras norte-americanas, quando comparadas com as brancas de classe média, apresentavam maior incidência de disputas, o que o levou a sugerir que as crianças negras estudadas construíam sua identidade social, cultivavam as amizades, mantinham e 
transformavam a ordem social da cultura de companheiros, através da oposição e da confrontação.

Kagan, Knight, Martinez e Santana (1981) compararam o comportamento de crianças mexicanas de três nichos ecoculturais: uma pequena cidade orientada para o comércio, uma cidade urbana industrializada e uma pequena cidade rural de base agrícola. As crianças da pequena cidade comercial mostraram-se mais competitivas em suas abordagens ao conflito com companheiros do que as demais. Elas preferiram continuar o conflito (67\% das respostas) a encerrá-lo, tendo para isso que romper com o colega (13\% das respostas). As crianças da comunidade rural e da industrializada não diferiram em suas respostas, mostrando esses grupos apenas uma leve preferência por continuar o conflito a usar táticas de rompimento. Fry (1988) constatou que a agressão entre companheiros era muito mais proeminente entre crianças de uma comunidade Zapotec violenta do que em crianças de uma comunidade vizinha pacífica. Esses dados sugerem que existe uma ligação entre padrões adultos específicos de relacionamento interpessoal e o manejo de conflitos entre crianças e que a mera distinção urbano-rural é insuficiente para explicar padrões distintos de administração de conflitos.

Uma interessante distinção é proposta por Ogbu (1993) para explicar as diferenças comportamentais encontradas em grupos étnicos nas sociedades ocidentais: diferenças culturais primárias e secundárias. Diferenças culturais primárias são aquelas existentes originalmente entre duas populações isoladas umas das outras e as secundárias dizem respeito às diferenças geradas por mecanismos usados pelas minorias para tratar de problemas que encontram em sua relação com membros de um grupo dominante. A esse respeito, Verbeek et al. (2000) citam estudos que encontraram que crianças mexicanas que viviam nos Estados Unidos da América tendiam a privilegiar soluções de conflito integradoras, enquanto as anglo-americanas utilizavam predominantemente a afirmação de poder para pôr fim a uma disputa. Os autores concluem que, por ora, é impossível saber-se se este achado se deve a diferenças sociais primárias ou secundárias. Novas pesquisas interculturais são necessárias para se esclarecerem situações como estas.

Embora os homens de todas as culturas estejam equipados para lidar com a estrutura complexa de mecanismos altamente especializados de processamento de informação, algumas sociedades, conforme descrevemos anteriormente, exigem maior especialização e complexidade, enquanto outras se configuram sobre estruturas mais simples. Podemos perguntar-nos em que medida as dimensões de códigos de comunicação (simples/ elaborado), de modelos de 
identidade (partilhada/diferenciada) e de estilos de criação (proximal/distal) relacionam-se com a incidência e tipos de conflitos em diferentes culturas.

Diferenças de gênero. Walters et al. (1998), em sua meta-análise de estudos a respeito das relações entre gênero e competitividade, relatam diversos estudos que revelam que, numa negociação, os homens são mais duros e regateadores do que as mulheres. Essas, por sua vez, mostram-se mais cooperativas, acomodando-se mais facilmente aos desejos dos outros. No entanto, o resultado do estudo dos autores, envolvendo 62 relatos de pesquisa sobre a relação entre gênero e comportamento competitivo em interações diádicas de negociação, indicou que as mulheres eram apenas levemente mais cooperativas do que os homens e se mostravam mais competitivas do que eles em barganhas em que o oponente usava uma estratégia do tipo olhopor-olho.

Num estudo de conflitos entre tríades de crianças do mesmo sexo numa escola do meiooeste americano, Sheldon (1992) encontrou que o estilo de conflito das meninas era mais brando, com estratégias de discurso mais colaboradoras e com foco no relacionamento, enquanto os conflitos dos meninos caracterizavam-se por um discurso mais carregado, com estratégias mais controladoras e com o foco em si próprios.

Underwood, Schockner e Hurley (2001), estudando crianças de cinco a sete anos de idade, verificaram que os meninos usavam mais força física para resolver conflitos do que as meninas. As meninas usavam mais estratégias de abrandamento para solucionar disputas. Entretanto, quando as meninas interagiam com o sexo oposto, tendiam a usar mais soluções envolvendo força do que quando entravam em conflito com outras meninas.

Segundo Laursen e Hartup (1989), a taxa de conflitos entre meninos é maior do que entre meninas. Martin e Fabes (2001) consideram que meninos conflitam mais, por serem mais competitivos do que meninas e por se preocuparem mais do que elas em dominar os colegas e em impor suas opiniões. Laursen e Hartup, estudando crianças de três a cinco anos de idade, constataram que, em geral, conflitos mais duros e agressivos ocorreram entre meninos e com parceiros do mesmo sexo. Em conflitos entre parceiros do mesmo sexo, os autores verificaram que meninos mostraram uma incidência maior de agressão física do que as meninas. Entretanto, os pequisadores declaram que os resultados foram equívocos quanto à agressão verbal. 
Murphy e Eisenberg (1996) verificaram que as meninas tendiam a ser mais complacentes com outras meninas do que em relação aos meninos e que as meninas relatavam mais estratégias construtivas para os conflitos e maior preocupação com a afiliação do que seus colegas. No entanto, as autoras também apontam que meninos considerados adequados e com bons níveis de funcionamento social tenderam a mostrar objetivos construtivos e preocupação com os outros na resolução dos conflitos. Diferenças individuais no funcionamento social parecem ter um papel fundamental no que as crianças pretendem fazer quando estão com raiva.

Os estudos citados, feitos predominantemente com crianças européias e americanas, em sociedades mais semelhantes à paulistana, levam-nos a supor que venhamos a encontrar características semelhantes no grupo de crianças de São Paulo.

No grupo de Ubatuba - tendo em vista as características mais conservadoras, estáveis e tradicionais de sua cultura, um modo de criação mais interdependente, bem como maior proximidade nas relações, em vista do menor tamanho da comunidade -, supomos que venhamos a observar um menor número de conflitos e maior preocupação com a manutenção das relações interpessoais.

\subsection{Zombaria}

A definição proposta para zombaria (teasing) por Keltner, Capps, Kring, Young e Heerey (2001) é: "uma provocação intencional, acompanhada de sinalizadores lúdicos que implica um comentário a respeito de alguma coisa relevante para o alvo" (ou vítima, objeto do ataque ou crítica: target em inglês - pág. 229). A zombaria contém um elemento de ambigüidade: embora freqüentemente hostil por natureza, a mensagem da zombaria traz indícios, tanto verbais quanto não verbais, de que a hostilidade não implica agressão. Muitas vezes, a mensagem de humor do desafio social pode ser mais destinada a chamar a atenção dos que assistem ao diálogo ou à cena do que aos próprios interlocutores ou alvos (Georgesen et al., 1999).

Kowalsky (2000) afirma que as caçoadas são comportamentos interacionais que algumas pessoas percebem como divertidos e outras, como cruéis e como meio de ferir os sentimentos alheios. Em inglês, diz o autor, a palavra tease vem de taesan, que significa rasgar 
em pedaços e da palavra francesa attiser, que significa alimentar o fogo com combustível sentido semelhante ao de atiçar em português.

Considerando que a zombaria é um comportamento que se encontra na fronteira entre a brincadeira e a provocação do conflito, diferenciá-la de ambos os comportamentos não é tarefa fácil, uma vez que os limites são tênues e, muitas vezes, fugazes. Dependendo do contexto e das crianças envolvidas, a zombaria (teasing) pode ser um convite para a brincadeira ou ser encarada como agressão, que pode gerar conflito. Convém também diferir provocação de brincadeira turbulenta distal, de intimidação (bullying) e de ironia. Na BT distal, os parceiros da brincadeira dão mostras claras de que estão brincando, ou seja, não se nota ambigüidade no comportamento e se observa reciprocidade nas interações. A intimidação diz respeito a comportamentos geralmente motivados por abuso de poder e pelo desejo de infligir dano físico ou psicológico à vítima (Naylor \& Cowe, 1999). Podemos dizer que, em alguns casos extremos, a zombaria pode ter efeito de intimidação, principalmente quando ocorre diante de um grupo. A questão da metalinguagem, ou da ambigüidade da zombaria, está também presente na ironia e no sarcasmo. Na definição tradicional de ironia, entretanto, supõe-se que as duas partes do enunciado irônico (o que é dito e o que está implícito) são opostas ou que há informações contrafactuais, isto é, informações literalmente discrepantes do contexto (Creusere, 1999). Já na intimidação, faltam os sinalizadores indiretos presentes na zombaria, sendo os atos considerados mais diretamente hostis.

Algumas provocações são humilhantes (por exemplo, fazer comentários que rebaixam o outro), outras desencadeiam menos dor e até provocam prazer (fazer cócegas e comentários mais saudáveis). A presença ou ausência de sinalizadores sutis terá influência sobre os efeitos negativos ou afiliativos da zombaria: as provocações com menor grau de sinalização implícita tendem a ser percebidas como literais, diretas e agressivas, enquanto aquelas acompanhadas de sinalizadores menos evidentes tendem a ser encaradas como lúdicas e engraçadas. A zombaria incorpora elementos que indicam que a provocação procura ser jocosa e afetuosa ao mesmo tempo (Keltner et al., 2001).

Em sua extensa revisão da literatura a respeito da zombaria, Keltner et al. (2001) afirmam que as pessoas caçoam umas das outras para se socializarem, flertarem, resolverem conflitos e passarem o tempo de maneira criativa e lúdica. Teria, portanto, a zombaria importante função na socialização, trazendo resultados pró-sociais, como afiliação e resolução adequada de conflitos. Conforme a maneira como se revela e as circunstâncias em que se 
apresenta, a zombaria pode, entretanto, levar a fins mais perturbadores, como, por exemplo, quando humilha ou embaraça o outro.

Keltner et al (2001) argumentam que a literatura sobre zombaria (teasing) é pequena, muitas vezes porque o conceito confunde-se ou funde-se com os de humor, brincadeira, sarcasmo, ironia e intimidação (bullying). Os autores ressaltam, ainda, que a zombaria é um processo relacional que, idealmente, requer que se estudem os indivíduos em situações naturais. Tratando o presente trabalho de fenômenos semelhantes entre si, com uma linha divisória tênue a separá-los, sentimos a necessidade de incluir em nossa análise as manifestações infantis de zombaria que ocorrem isoladamente, ou antes, ou durante as brincadeiras e conflitos.

Parte da dificuldade da apreensão do fenômeno da zombaria deve-se a sua ambigüidade ou a dificuldades do alvo em entender os motivos de quem a emitiu. A principal dúvida é: estaria tal pessoa brincando ou tentando ridicularizar e humilhar? Quando indagadas a respeito dos motivos pelos quais achavam que seus companheiros caçoavam dos outros, algumas crianças relataram: "porque querem parecer legais" ou "a zombaria faz os outros pensarem que você detém o poder" ou "se você vê alguém muito diferente, é assustador" (Kowalsky, 2000). Nesse último caso, supõe-se que as crianças, ao caçoarem dos companheiros, poderiam estar procurando distanciar-se de estímulos amedrontadores. Shapiro, Baumeister e Kessler (1991) sugerem que a zombaria é uma maneira de estabelecer dominância social, um meio de promover conformidade dentro de um grupo e um mecanismo para disfarçar os verdadeiros sentimentos e intenções do indivíduo que a promove. Há muitas diferenças individuais nesse aspecto: enquanto algumas pessoas raramente caçoam de seus pares, outras são caçoadoras contumazes.

Relacionando estudos que mostram maior incidência de zombaria em situações que potencialmente gerariam conflito, Keltner et al. (2001) afirmam, ainda, que a zombaria pode ocorrer em resposta a conflitos em potencial, permitindo que os indivíduos negociem os problemas virtualmente antes que surjam. Nessa medida, parece que, se, por um lado, a zombaria pode ser um importante elemento de abrandamento de conflitos, promovendo a coesão grupal, por outro, pode ser considerada negativa, quando é usada para fortalecer os laços entre pessoas outras que não o alvo, ou seja, quando é empregada como meio de escarnecer ou de levar o alvo ao ostracismo. Kowalsky (2000) pondera que as caçoadas são consideradas aversivas quando indicam desvalorização da relação. Essa desvalorização pode não ser intencional por parte de quem caçoa, mas pode causar embaraço, rejeição e exclusão do alvo da caçoada. $\mathrm{O}$ autor fala então da má zombaria (que leva à exclusão) e da boa zombaria (que leva à 
inclusão). Sumarizando, a zombaria pode conduzir à camaradagem e ao riso ou produzir lágrimas e rompimentos.

A zombaria costuma referir-se a algo que diz respeito à vítima do ataque ou à relação entre o agente e o alvo da caçoada ou a algum objeto de interesse do alvo. A provocação zombeteira está, freqüentemente, relacionada com algum aspecto desviante da aparência física, da personalidade, das habilidades intelectuais ou sociais ou do comportamento social do alvo (Keltner et al., 2001).

Alguns estudos mostram que as lembranças de zombaria têm conotações diferentes conforme a pessoa se veja no papel de alvo ou de agente. Kowalsky (2000), num estudo com adultos, constatou que vítimas e perpetradores de zombarias tinham avaliações diferentes do mesmo evento. Os agentes das caçoadas percebiam-nas como mais humorísticas, enquanto as vítimas percebiam-nas como mais irritantes. As vítimas também se percebiam como menos positivamente avaliadas do que os perpretadores as consideravam. Os perpetradores, por sua vez, supunham que eram encarados mais favoravelmente do que as vítimas os julgavam. Relativamente ao alvo, os agentes das caçoadas minimizam o impacto negativo de seu comportamento, encaram-no como lúdico, percebem-no como causado por motivos racionais e vêem as consequiências de sua conduta como de âmbito limitado.

Considerando a zombaria do ponto de vista ontogenético, Dunn e Slomkowsky (1992) apontam-na como um dos primeiros sinais do crescimento da apreensão das crianças em relação aos estados e sentimentos dos outros. Através da zombaria (freqüentemente não verbal no segundo ano de vida), a criança revela algum entendimento do que aborrece e perturba o outro. Esse fato é freqüentemente observado durante o conflito entre irmãos. Dunn e Slomkowsky constataram que, entre 16 e 18 meses de idade, já se observam exemplos de crianças tirando o polegar da boca do irmão (sugado em momentos de estresse) durante um conflito ou aborrecendo-o com um brinquedo de aranha (após a mãe dizer que o irmão tem medo de aranha). Tais atos se tornam mais elaborados e verbais durante o segundo e terceiro anos de vida. Trinta e seis de 40 crianças observadas por Dunn e Slomkovsky já faziam zombaria aos 24 meses de idade. Georgesen et al. (1999) afirmam que, enquanto a zombaria entre adultos contém mais indícios de humor e de ludicidade, a caçoada infantil fere freqüentemente o outro, sendo dirigida aos que são diferentes ou não apreciados pelos colegas.

A presença de sinalizadores implícitos (off-record) na zombaria requer que o parceiro da interação seja capaz de usar e de entender a comunicação não literal. Estudos relatados por Keltner et al. (2001) demonstram que crianças de oito a dez anos são capazes de diferenciar, 
através de episódios filmados, uma luta séria de brincar de luta, por intermédio de sinalizadores pouco evidentes, como expressões faciais, entonação verbal e riso. Entretanto, se crianças desde os seis anos de idade identificam adequadamente sinalizadores não evidentes mais conspícuos, é apenas por volta dos 11 anos que se tornam capazes de entender de forma mais contundente a ironia e o sarcasmo. Creusere (1999) afirma que crianças mais novas (com seis anos de idade) são capazes de reconhecer alguns componentes do cenário irônico. Por exemplo, a compreensão da não-literalidade da ironia precede no desenvolvimento o reconhecimento da intenção do agente do sarcasmo. Podemos esperar que os participantes do presente estudo, com cerca de cinco anos de idade, já reconheçam formas salientes de zombaria, embora apresentem um viés na direção de interpretá-la de forma literal.

O conteúdo da zombaria também difere de acordo com a idade. Keltner et al. (2001) apresentam evidências de que posse e agressão são questões relevantes nos anos pré-escolares. Nos primeiros anos escolares, são alvos de zombaria questões de relacionamento com o sexo oposto. Na puberdade, são motivos de caçoada comportamentos relacionados a moda e namoro e, na adolescência, condutas relacionadas a sexo e drogas. Shapiro et al. (1991), estudando crianças de diversas idades, encontraram apenas uma diferença de gênero entre relatos de zombaria: as meninas caçoavam da aparência física dos outros significativamente mais do que os meninos. Durante os anos pré-escolares, meninos e meninas apresentavam formas aparentemente semelhantes de provocar seus pares. Depois da pré-escola, entretanto, as zombarias dos meninos tomavam um caráter mais insidioso.

As respostas consideradas mais efetivas à zombaria são as humorísticas, enquanto as menos efetivas são as agressivas (Georgesen et al., 1999). Keltner et al. (2001) afirmam que a hostilidade na zombaria pode crescer com a familiaridade, ao mesmo tempo em que aumentam outros processos que a tornam mais afiliativa e agradável. Entre as crianças, observam-se também diferenças de reação à caçoadas, em função de traços de personalidade e de status sociométrico. Georgesen et al. relatam que crianças de baixo status sociométrico e pouca popularidade avaliavam que as respostas agressivas à zombaria eram apropriadas, que o caçoador estava sendo hostil e produziam menos respostas efetivas a provocações. Feldman e Dodge (1987) constataram que crianças negligenciadas e rejeitadas atribuíam mais intenção hostil a caçoadas do que crianças de alto status sociométrico (populares e médias). Otta (comunicação pessoal) alerta que esse efeito pode ser devido aos diversos graus e tipos de zombaria que sofrem crianças de diferentes status sociométricos. É possível que crianças 
populares sejam vítimas de caçoadas de teor mais leve do que aquelas pouco aceitas pelos colegas.

Em adultos, Georgesen et al.(1999), investigando a influência de fatores de personalidade, encontraram que os indivíduos com altos escores na qualidade de ser agradável classificavam as caçoadas como táticas comportamentais efetivas e que aqueles com altos escores em neuroticismo relatavam que a zombaria os deixaria mais bravos. Indivíduos neuróticos sentiam que respostas hostis à zombaria eram mais efetivas. Conseqüentemente, era esperado que, na prática, respondessem de forma reativa e retaliativa a esse tipo de comportamento.

Pesquisas interculturais a respeito da zombaria são muito raras e os estudos realizados em diferentes comunidades usaram metodologias distintas, o que dificulta comparações entre culturas em relação a esse tipo de comprtamento. Apesar disso, Keltner et al. (2001) supõem que exista considerável variação intercultural nas práticas de zombaria. Relatam estudos que evidenciam que, enquanto muitas mães de famílias americanas, brancas, de classe média raramente zombam de seus filhos, em outros grupos étnicos e culturais - como americanos de origem asiática, havaianos e mexicanos -, mães, pais e outros adultos freqüentemente zombam das crianças, embora haja evidências de que, nesses grupos, as provocações tenham caráter pouco hostil. Esse dado também é descrito por Bonta (1997) em relação aos nativos de Bali.

\subsection{Síntese}

Supõe-se que o desenvolvimento da cognição humana deva-se, em grande parte, à necessidade de regulação mútua do comportamento de co-específicos e dos ajustes necessários para a vida em sociedade. Tendo em vista que características dos grupos de brincadeira se constróem a partir de múltiplas interações e relações e que o conflito tem um caráter essencialmente interativo, a questão dos relacionamentos interpessoais permeia diversos aspectos levantados no presente trabalho.

Apesar das inquestionáveis vantagens da vida em grupo e de coordenar ações com os outros, a limitação de recursos acarreta também competição, que se revela desde cedo no desenvolvimento humano. Entre as estratégias de competição, destacam-se, segundo Charlesworth (1996), ataque físico, ameaça verbal, coerção, zombaria, intimidação, adulação, 
apaziguamento, tirar partido de uma situação, mentir, distorcer, enganar, dissimular, ajudar, compartilhar e trabalhar com os outros.

O estudo dos conflitos nos remete praticamente a todas essas estratégias. Considera-se que os conflitos desempenham importantes funções na regulação e ajustamento social de todos os grupos e em todas as idades. Embora os conflitos impliquem também um potencial destrutivo, eles mais freqüentemente apresentam consequiências construtivas, na medida em que fornecem informações sobre os objetivos, interesses e valores dos outros e que levam os grupos ao estabelecimento de regras, normas e sistemas de expectativas mútuas, que servem para reduzir a incerteza e para promover coesão social nos relacionamentos interpessoais.

Neste trabalho, encapamos a definição de conflitos proposta por Lyons (1993), que considera que os conflitos sociais tendem a ser episódicos, começando com a incompatibilidade entre as ações, objetivos e interesses de dois ou mais participantes e terminando quando as discordâncias são resolvidas, ao menos temporariamente, através de alguma forma de acomodação, condescendência, submissão ou falta de oposição de um ou de ambos os participantes. Consideraremos quatro momentos dos conflitos: instigação, causa ou motivo, estratégia de oposição, estratégia de reação à oposição e desenlace.

Os conflitos estão menos presentes em sociedades cujos membros mantêm relações mais harmoniosas entre si e são mais freqüentes em grupos sociais que incentivam a autonomia e a competição entre seus membros e nos quais as desigualdades sociais são maiores. Estudos com crianças euro-americanas sugerem que meninos conflitam mais do que meninas e são mais agressivos, assertivos e dominadores nas relações interpessoais do que elas, enquanto as meninas se mostram mais dóceis e preocupadas com as conseqüências das discórdias para os relacionamentos - fatos que levam a diferentes caminhos de enfrentamento e de resolução de conflitos em função do sexo da criança.

O comportamento de zombaria se coloca neste estudo em função de sua proximidade e interface com os conflitos e com as atividades lúdicas, principalmente as que envolvem um caráter socialmente contingente. É definido como comportamento que implica componentes implícitos de ludicidade e de hostilidade, sendo essencialmente ambíguo em sua natureza e na forma como é interpretado pelos parceiros de interação. Supõe-se que, através da zombaria, manifestem-se os primeiros sinais da apreensão das crianças em relação aos estados e sentimentos dos outros e de seu entendimento do que aborrece e perturba o outro. A incidência 
desse comportamento varia de uma sociedade para outra. Embora pareça paradoxal, conforme apontaram Keltner et al. (2001) e Bonta (1997), em algumas comunidades em que a comunicação é mais direta, a zombaria é uma prática constante e aceitável, principalmente no que se refere à educação das crianças. 


\section{OBJETIVOS DO ESTUDO E HIPÓTESES INICIAIS}

\subsection{Objetivos}

O principal objetivo que norteou o presente trabalho foi comparar o comportamento de crianças de dois grupos culturais, levando em consideração o gênero dos participantes, variável que, como já apontamos, está intimamente relacionada com os aspectos culturais. Assim procedendo, visamos a contribuir para a constatação de universais do desenvolvimento infantil e de suas variações, em função de diferentes ambientes e valores de criação. Para a avaliação de peculiaridades de cada grupo, pautamo-nos, principalmente, em dados obtidos através das observações comportamentais das crianças. Secundariamente, baseamo-nos em algumas informações fornecidas pelos educadores das escolas freqüentadas pelas crianças, em relatos escritos sobre as duas comunidades (Marcílio,1986; Setti, 1985) e na observação das condições de vida a que estão submetidos seus moradores.

Procurou-se retratar a socioecologia dos dois grupos de crianças, que, além de proporcionar a caracterização de diferenças entre o funcionamento e a configuração dos dois grupos de brincadeira, será utilizada como pano de fundo para o estabelecimento de comparações de outros comportamentos estudados.

Foram explorados comportamentos que têm sido pouco pesquisados em estudos de diferentes culturas: as brincadeiras de contingência social, a zombaria e os conflitos infantis. Quanto às brincadeiras de contingência social não turbulentas e à zombaria, há escassez de pesquisas, mesmo em comunidades de crianças européias e americanas. Propusemo-nos a testar uma categorização, ainda não utilizada em outros estudos, que possibilitasse a análise do comportamento dos dois grupos, em relação a brincadeiras de contingência social, a provocações e a conflitos.

Mais especificamente, visamos a comparar crianças dos dois grupos e gêneros em relação a: (1) características do grupo de brincadeira (tamanho e constituição); participação nas diferentes modalidades de brincadeira, segundo o caráter predominante das ações envolvidas (brincadeiras simbólicas, de exercício físico, de contingência física, de contingência social, de construção e jogos de regras); (3) envolvimento nos diversos tipos de brincadeiras, quanto à forma de interação social (brincadeiras solitárias, paralelas, 
associativas e cooperativas ou competitivas); (4) participação nas diversas modalidades de brincadeiras de contingência social (turbulentas/não turbulentas, distais/proximais); (5) comportamentos de zombaria; (6) freqüência, número de elos, alianças e componentes de conflitos (motivos aparentes, estratégias de oposição, de reação e desenlace).

Consideramos que este estudo tem um caráter predominantemente exploratório, ou seja, assumimos um olhar curioso e indagador para os fenômenos comportamentais, esperando descrevê-los e conhecê-los melhor, sem o objetivo de testar nenhuma hipótese apriorística. Contudo, como é próprio do espírito de investigação e levando em conta todas as considerações feitas anteriormente, é possível fazer algumas suposições iniciais do que esperamos encontrar.

\subsection{Hipóteses iniciais}

Supõe-se que os estilos de criação proximal/distal, na acepção dada por Keller (1998), refletir-se-ão na atividade lúdica - através de maior freqüência de brincadeiras de exercício físico e de contingência social entre as crianças ubatubanas e de maior incidência de brincadeiras simbólicas entre as paulistanas - e no estilo de resolução de conflitos, que deverão ser de natureza predominantemente proximal e direta entre as crianças de Ubatuba e distal e verbal entre as paulistanas. Espera-se também encontrar alguma influência do grupo cultural sobre a natureza das brincadeiras de contingência social. Podemos supor que as brincadeiras socialmente contingentes das crianças da praia envolvam maior contato físico, enquanto as mesmas brincadeiras tenham caráter mais distal nas crianças paulistanas.

Embora não tenhamos isolado o nível socioeconômico como variável de estudo, não podemos subestimar sua importância. Esse construto traz diversas implicações (Ribas, Seidl de Moura, Soares, Gomes e Bornstein, 2003), que não pudemos medir com os instrumentos de que dispúnhamos. No grupo de São Paulo, conforme detalhamos nos capítulos 3 e 6, encontramos crianças de diferentes níveis socioeconômicos e, em Ubatuba, a maioria dos participantes pertencia a famílias da classe trabalhadora. Dificilmente, poderemos atribuir as diferenças encontradas exclusivamente ao nível socioeconômico das crianças, conquanto suponhamos que o das crianças de São Paulo fosse superior ao das ubatubanas, principalmente se levarmos em consideração o nível educacional dos pais. Consideramos que a questão socioeconômica esteja 
implicada nas diferenças estabelecidas entre os códigos de comunicação simples/complexo e os modelos de identidade partilhada/diferenciada.

Segundo o critério de Nicolaci-da-Costa (1988), pressupõe-se que as crianças ubatubanas tenham sido criadas com base no modelo de identidade partilhada, enquanto a maioria das paulistanas o foi dentro do modelo de identidade diferenciada. Assim sendo, conjectura-se que as crianças dos dois grupos culturais apresentem comportamentos compatíveis com o que se prevê através do paradigma que preconiza diferenças nos códigos de comunicação, em decorrência dos modos de produção de cada sociedade. Espera-se, assim, encontrar predominância do código simples entre as crianças ubatubanas, implicando que as suas brincadeiras tendam a envolver menor simbolismo e abstração e a constituir-se de atividades mais práticas e concretas do que aquelas das paulistanas. Hipotetiza-se, também, que os conflitos sejam resolvidos de formas mais simples e diretas entre as crianças ubatubanas e de maneira mais verbalmente elaborada entre as paulistanas.

Como o código simples de comunicação coincide com um modelo de identidade partilhada, em que os papéis são tradicionalmente estabelecidos, pode-se esperar que os conflitos em Ubatuba ocorram com menor frequiência do que em São Paulo, uma vez que é possível que as crianças ubatubanas tenham interiorizado, através de uma educação mais conservadora, limites mais claros para suas condutas.

Na comparação entre os grupos, podem-se aventar duas hipóteses alternativas para as soluções dos desentendimentos. Por um lado, a constituição da sociedade de Ubatuba sobre bases que favorecem a interdependência pode levar a soluções mais negociadas entre as crianças desse grupo; por outro, a predominância do código simples de comunicação pode implicar uma menor discussão das disparidades e, portanto, menor negociação, acarretando predomínio de soluções unilaterais de conflitos entre elas. Pode-se esperar, de acordo com o paradigma de identidade diferenciada e de código de comunicação elaborado, que as crianças paulistanas, durante os conflitos, verbalizem mais seus sentimentos, intenções e desejos do que as ubatubanas.

Em virtude da escassez de estudos interculturais que utilizem metodologias semelhantes na investigação dos comportamentos de zombaria, é difícil fazer uma previsão mais consistente a respeito dos resultados que podemos encontrar na comparação entre os dois grupos culturais. Contudo, levando em consideração os mesmos argumentos empregados nas hipóteses anteriores e dada a sutileza e ambigüidade da zombaria, bem como as diferentes gradações deste 
comportamento, podemos levantar duas hipóteses alternativas: (i) pode-se supor que as crianças de Ubatuba, em vista dos dados já relatados sobre sociedades tradicionais - em que a zombaria chega a ser uma prática educativa -, apresentem um maior número de comportamentos de zombaria; ou (ii) que as crianças da praia - detentoras de um código mais simples de comunicação e de um tipo de interação mais direta e proximal - recorram menos a zombaria do que as crianças paulistanas.

Esperamos constatar as conhecidas diferenças de gênero quanto à participação nos diversos tipos de brincadeira, com os meninos apresentando mais brincadeiras turbulentas e de exercício físico e as meninas, mais brincadeiras de faz-de-conta e de contingência social (Carvalho et al., 1993; Pellegrini \& Smith,1998). Esperamos, ainda, encontrar diferenças de gênero mais acentuadas no grupo de Ubatuba, em razão de seus valores mais tradicionais, que tenderiam a preservar maior estereotipia de papéis sexuais nesse grupo. Conjecturamos que, como as crianças de São Paulo são, em sua maioria, filhos e filhas de funcionários da Universidade - que convivem com valores mais avançados e que tendem a incentivar o desenvolvimento de uma identidade diferenciada -, haja menor estereotipia de gênero nesse grupo. Como afirmam Carvalho et al. (1993), a socialização cultural não se restringe à transmissão dos papéis adultos para as crianças, mas "envolve a compreensão e interpretação ativas dos papéis de gênero pelas crianças" (pág. 30). Quanto ao conflito, espera-se, com base em dados da literatura (Sheldon, 1992; Underwood et al., 2001), que as meninas apresentem menor freqüência de conflitos e estratégias de resolução mais afiliativas, com ênfase na preservação dos relacionamentos, e que os meninos usem técnicas mais coercitivas e empreguem mais a força física para resolver disputas.

Podemos supor que, afora as características culturais já citadas, as crianças de comunidades menores - em que os níveis de violência, de competição e de estresse para garantir os meios de sobrevivência são mais baixos do que nas grandes metrópoles - apresentem, em ainda outros aspectos, comportamentos diferentes daquelas criadas no meio urbano densamente povoado, quanto à maneira de se relacionarem socialmente, quanto ao tipo e conteúdo das brincadeiras preferidas e quanto à forma e ao grau de conflito em que se envolvem. Não só os valores e o esforço emocional para garantir a subsistência diferem entre os dois subgrupos culturais. Pode-se conjecturar que a menor competição pelo espaço físico no meio praiano, advinda de um menor adensamento demográfico, assim como a facilidade de acesso à natureza e a proximidade com elementos naturais (rios, lagos, cachoeiras, matas, praias, mar) influenciem a forma de as crianças brincarem e se relacionarem. Essas diferenças no ambiente podem acarretar 
menor disputa por espaço entre as crianças ubatubanas, maior expansão física e maior aproveitamento de elementos naturais em suas brincadeiras.

Como certos fatores que caracterizam a vida moderna das metrópoles - entre eles a grande exposição à TV, a super-solicitação e a demanda excessiva de atividades programadas pelos adultos para as crianças - nos parecem menos presentes na coletividade ubatubana, onde são substituídos, em grande parte, pela convivência familiar e com os vizinhos e por mais espaço e tempo para a brincadeira livre . Pelas mesmas razões, supomos que o brincar das crianças ubatubanas não sofra tanta influência da mídia e que seja possível resgatar, entre essas crianças, brincadeiras mais tradicionais, ou "de rua", bem como uma maior diversidade de brincadeiras e jogos coletivos, favorecidos por uma zona lúdica ampliada em termos de espaço e de tempo. Em contrapartida, esperamos encontrar maior influência da mídia, dos meios eletrônicos e da oferta comercial de brinquedos manufaturados nas brincadeiras das crianças paulistanas. 


\section{APRESENTANDO OS GRUPOS E AS BRINCADEIRAS}

Descrevemos, neste capítulo, algumas características dos grupos de brincadeira, tendo por parâmetros seu tamanho e composição. Verificamos, também, a distribuição das diversas modalidades interacionais e formas de atividade lúdica, procurando estabelecer algumas relações entre esses indicadores e identificar características observadas no comportamento de meninas e meninos dos dois grupos culturais estudados (Figura 7.1). Com essa sistemática e perspectiva de análise, objetivamos caracterizar os grupos estudados em termos interacionais e de ludicidade, o que permitirá, além de uma visão geral de como eles se organizam e de como se desenvolve a brincadeira, a constatação de semelhanças e diferenças entre os dois grupos culturais e gêneros. A análise das formas de organização dos grupos de brincadeira e das preferências lúdicas das crianças contribuirá, também, para a constituição de um quadro mais completo que propicie um melhor entendimento de como processam as provocações e interações conflituosas, que serão abordadas no próximo capítulo.

\subsection{Tamanho e composição do grupo}

A maneira como as crianças se organizam em grupos, segundo os critérios de tamanho e de composição, é um interessante pano de fundo para a análise das condições sob as quais ocorrem as interações. Dados da literatura mostram-nos que pré-escolares relacionam-se principalmente com crianças do mesmo sexo e que meninas interagem principalmente em díades (Benenson, 1993; Bjorklund \& Pellegrini, 2001; Fabes et al., 2003; La Freniere, Strayer \& Gauthier, 1984; Maccoby, 1988; Souza \& Rodrigues, 2002). Procuramos verificar até que ponto tais constatações se confirmam em meninos e meninas dos dois grupos culturais estudados. 


\subsubsection{Tamanho do grupo, segundo origem e gênero}

Inicialmente, foram calculadas as proporções de participação em brincadeira nos diversos tamanhos de grupo, dividindo o número de participações de cada criança em díades, tríades e políades (grupos com quatro ou mais elementos) pela participação total em brincadeira grupal. Utilizou-se, então, uma MANOVA 2 x 2 para testar o efeito de origem e de gênero sobre essas proporções. Essa análise revelou efeito de interação entre os dois fatores: origem e gênero (Lambda de Wilks $=0,989, \mathrm{~F}_{2,34}=3,723, \mathrm{p}<0,05$ ). Análises univariadas subseqüentes mostraram efeito de interação estatisticamente significativo sobre políades $\left(\mathrm{F}_{1,35}=7,633\right.$, $p<0,01)$ e efeito marginalmente significativo sobre tríades $\left(F_{1,35}=2,827, p=0,01\right)$. Em São Paulo, os meninos participaram mais de grupos grandes do que as meninas e essas se envolveram mais em tríades do que eles, enquanto, em Ubatuba, as meninas participaram mais de políades do que os meninos e esses, mais de tríades do que elas. A participação de meninos e meninas em díades foi praticamente equivalente, tanto em São Paulo quanto em Ubatuba. (Figura 7.2).

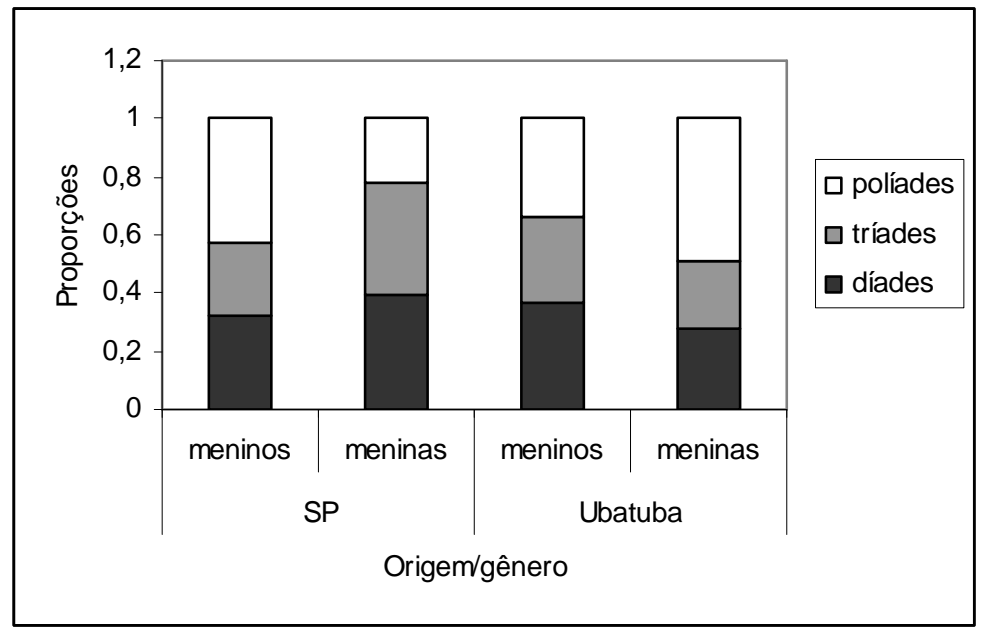

Figura 7.2. Proporções dos diferentes tamanhos de grupo, segundo origem e gênero.

Observe-se que, diferentemente do que se poderia esperar pelos dados da literatura internacional (Maccoby, 1988; Benenson et al., 2001), praticamente não se constataram, nos dois grupos culturais, diferenças entre os gêneros na freqüência de participação em díades: tanto meninos quanto meninas de São Paulo e de Ubatuba passaram aproximadamente o mesmo 
período de tempo interagindo em díades. Já em relação aos grupos grandes, o comportamento das meninas de Ubatuba foi semelhante ao dos meninos de São Paulo. Enquanto a preferência desses por grupos grandes era esperada, em vista de dados de outros estudos (Hartup, 1983; Markovits et al., 2001), a alta freqüência de participação em grupos grandes por parte das meninas ubatubanas contrariou as expectativas.

Dois pontos, portanto, merecem destaque: a participação dos meninos dos dois grupos em díades, aproximadamente equivalente àquela das meninas e o grande envolvimento em grupos grandes por parte das meninas de Ubatuba. Ambos os dados conduzem-nos a pensar numa menor estereotipia de papel de gênero nos dois grupos estudados. Esse fato seria de se esperar no grupo de São Paulo, cujas crianças provêm de famílias em que um ou ambos os pais convivem num ambiente universitário e, portanto, presumivelmente mais liberais e flexíveis em relação aos papéis de gênero. Contudo, em Ubatuba, em que poderíamos esperar definições mais tradicionais dos papéis de gênero, observaram-se meninas contrariando a idéia comum de que elas preferem agrupar-se em díades. Será essa uma particularidade da amostra estudada, com meninas muito ativas e "molecas" ou uma tendência observada em grupos da mesma região e cultura caiçara? Não temos resposta ainda. Seriam necessárias pesquisas mais extensas na região para obter mais elementos para responder essa questão.

Enquanto políades e díades foram mais abordadas em estudos internacionais, as tríades receberam menor atenção por parte dos pesquisadores. Lansford e Parker (1999), entre os poucos autores que se dedicaram a estudar o comportamento de crianças em tríades, fornecem alguns argumentos que evidenciam a importância de se destacar esse tipo de composição grupal. As tríades, em contraposição com as díades, já permitem a formação de coalizões e o estabelecimento de hierarquias de influência e de dominância. Os autores sugerem, ainda, que as díades de meninas são mais receptivas à entrada de terceiras partes do que as dos meninos, o que é congruente com os dados das meninas de São Paulo.

Outro argumento que se levanta em relação às tríades considera que elas seriam composições grupais mais instáveis e tenderiam a se transformar em díades nos grupos femininos e em grupos maiores entre os meninos (Benenson et al. 2001; Lansford \& Parker, 1999). No entanto evidências de agrupamentos de indivíduos em estágios posteriores de desenvolvimento mostram que adolescentes preferem constituir-se em tríades. As tríades trazem, simultaneamente, algumas vantagens das díades e das políades: permitem relações mais íntimas, mas, também, evitam o confronto direto das relações diádicas exclusivas. Pode-se dizer 
que a triangulação, assim como as interações em grupos grandes, possibilita a diluição das emoções tanto positivas quanto negativas, o que se torna uma vantagem para a manutenção da coesão grupal.

\subsubsection{Composição do grupo, segundo origem e gênero}

A ANOVA para testar o efeito de origem e de gênero sobre a proporção de participações em grupos mistos calculadas em relação às participações grupais totais em brincadeira revelou influência de gênero $\left(\mathrm{F}_{1,31}=4,064, \mathrm{p}=0,05\right)$. Os meninos brincaram mais em grupos mistos do que as meninas (Figura 7.3).

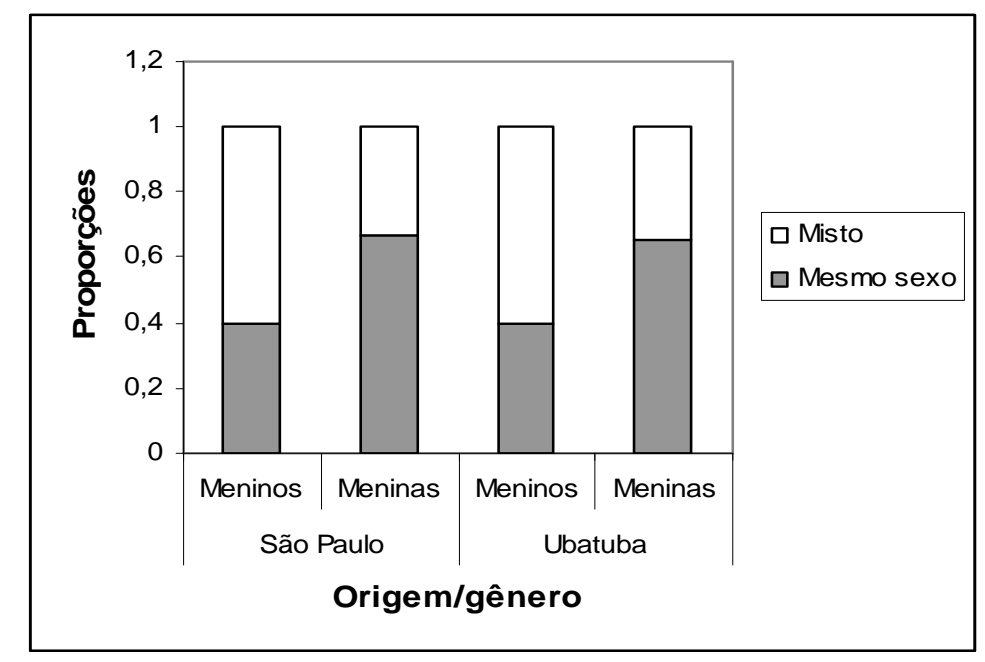

Figura 7.3. Proporções de grupos mistos e do mesmo sexo, segundo origem e gênero.

Maccoby e Jacklin (1987) encontraram que, por volta dos quatro anos e meio, pré-escolares passavam três vezes mais tempo brincando em grupos do mesmo sexo do que com o sexo oposto. Pela Figura 7.3, constata-se que este dado se confirmou para as meninas. Meninas paulistanas apresentaram tendência semelhante à das ubatubanas nesse aspecto, ocupando, em comparação com a inserção em grupos mistos, cerca do dobro do tempo de brincadeira em grupos do mesmo gênero. 
Apesar de ter sido constatada uma maior segregação sexual entre as meninas, não se observaram discriminações explícitas em razão do sexo, embora algumas crianças tenham sofrido exclusão por parte das demais. A ausência de constatação de discriminação por motivo do sexo do parceiro nos leva a supor que é possível que a atração por crianças do mesmo sexo prevaleça sobre a rejeição de companheiros de sexo oposto, conforme sugeriram Sippola et al. (1997) e Harris (1998), que propõem que se diferencie conceitualmente atração de rejeição. Esses autores consideram que se deva analisar separadamente a atração por indivíduos do mesmo sexo e a rejeição daqueles de sexo oposto. Transcrevemos a seguir dois exemplos ilustrativos de que crianças pouco aceitas pelo grupo sofreram algum tipo de sinalização negativa, tanto por parte de colega de mesmo sexo quanto de companheiro do sexo oposto.

$\underline{\text { Exemplos de reação de colega de sexo }}$ Exemplos de reação de colega de mesmo oposto $\underline{\operatorname{sexo}}$

a) Aca (menina) pendura-se na árvore, solta-se e ri.

Rola no tronco e pula.

Chega Ig (menino) - Sai!

Aca - Tou brincando aqui!

b) Mi (menina) estoura bexigas imaginárias, vocalizando: ta...tá...tá....

Le (menino) a imita: ta... tá ...

Le joga grama em todas as crianças do grupo..

Ja (menina) diz a Le: Pára, sai daqui!

Le sai. a) Ja (menina) bate a corda e diz para Aca (menina): Fora!

Aca - Não!

b) Le (menino) enfia o pé no buraco que Mar (menino) cava.

Mar chama a professora para denunciar a conduta do colega.. Le sai e passa a cavar freneticamente com outra pá em vários lugares. 
Como se trata apenas de uma impressão qualitativa, seria interessante, em trabalho futuro, verificar se as crianças sofrem mais exclusões por parte de colegas de sexo oposto. Pelos dados registrados, observamos que, ao menos conscientemente, as crianças não explicitaram rejeição por motivo de diferenças sexuais. Theimer, Killen e Strangor (2001) argumentam que é possível que as crianças não aleguem exclusões por motivo de gênero por acreditarem que isso pode ser "errado" do ponto de vista moral, ofensivo ou danoso ao outro. Os autores, porém, explicitam que as alegações verbais das crianças - em resposta a perguntas a respeito de sua opinião a respeito de excluir companheiros por motivo de seu sexo - são diferentes de seu desempenho real, que evidencia que, na prática, existe segregação. Parece não ter sido esse o caso dos meninos dos dois grupos culturais. É possível, contudo, que medidas indiretas, como maior ou menor grau de exclusão real em brincadeiras, possam esclarecer melhor essa questão.

Encontram-se na literatura outros argumentos para explicar a segregação sexual. Bjorklund e Pellegrini (2001), numa perspectiva funcional, consideram que as brincadeiras com crianças do mesmo sexo são um importante meio para adquirir e dominar comportamentos específicos do próprio sexo. Para Maccoby (1996), a base para que haja relações mais freqüentes com o mesmo sexo se deve ao fato de que preferimos relacionar-nos com base na semelhança de estilos interacionais. Serbin, Sprafkin, Elman.e Doyle (1984) explicam a segregação sexual fundamentando-se no fato de que meninos e meninas teriam estratégias diferentes de influenciar os outros: meninas usariam mais sugestões polidas e meninos, ordens diretas. Ao mesmo tempo, Maccoby (1988) argumenta que os relacionamentos provavelmente se manterão no tempo, quando ambas as partes puderem influenciar umas às outras. Nessa perspectiva, pela tendência demonstrada por meninos e meninas dos dois grupos culturais, podese supor que os meninos se sentiram mais à vontade para brincar e se relacionar em grupos mistos do que suas colegas do sexo feminino, o que reafirma uma menor estereotipia sexual do que a apresentada por crianças de estudos internacionais.

Os contrastes e peculiaridades de comportamento de meninos e meninas dos dois grupos culturais, em termos dos dados relativos a tamanho e composição dos grupos, remetem-nos a particularidades na configuração dos diversos grupos de brincadeira e, em última instância, à microcultura do grupo de brincadeira, que se definirá mais claramente ao descrevemos as brincadeiras de ambas as comunidades. 


\subsubsection{Composição em relação ao tamanho do grupo}

Tomando-se as crianças de São Paulo e de Ubatuba como um todo, testou-se, através de testes t de amostras pareadas, se as crianças se compunham com o sexo oposto relativamente mais em díades, tríades ou em grupos grandes, usando-se os índices relativizados: díades mistas/total de díades, tríades mistas/total de tríades e políades mistas/total de políades. Encontrou-se que a composição mista em grupos grandes foi proporcionalmente mais freqüente do que em díades $\left(\mathrm{t}_{14}=2,128, \mathrm{p}<0,05\right)$ e do que em tríades $\left(\mathrm{t}_{18}=2,547, \mathrm{p}<0,05\right)$, o que era de se esperar, uma vez que há maior probabilidade da participação conjunta de meninos e meninas em grupos grandes.

Para comparar os diferentes tamanhos de grupo quanto à composição por gênero nas duas comunidades, computou-se a freqüência de participação em grupos mistos da criança focal em díades, tríades e políades em relação ao total de participação grupal de cada criança. A MANOVA calculada para testar a influência de origem e de gênero sobre esses índices revelou efeito global significativo de origem (Lambda de Wilks $=0,775, \mathrm{~F}_{3,33}=3,209, \mathrm{p}<0,05$ ). Análises univariadas subsequientes revelaram efeito estatisticamente significativo de origem sobre as díades $\left(\mathrm{F}_{1,35}=4,788, \mathrm{p}<0,05\right)$ e marginalmente significativo sobre as tríades $\left(\mathrm{F}_{1,35}=3,415\right.$, $\mathrm{p}<0,10)$. As crianças de São Paulo se compuseram mais em díades e tríades mistas do que as de Ubatuba (Figura 7.4).

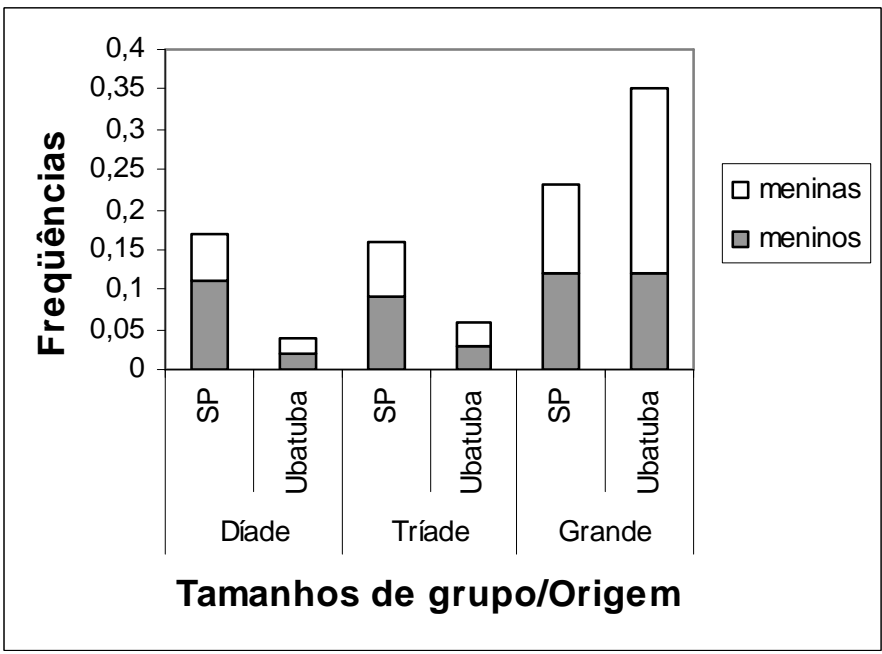

Figura 7.4. Freqüências relativas ao tempo de díades, tríades e políades mistas, conforme origem e gênero. 
Os dados apresentados na Figura 7.4 revelam que, entre as crianças de Ubatuba, a composição mista prevaleceu nos grupos grandes, em que é mais provável a participação de crianças de ambos os sexos. Martin e Fabes (2001), revendo estudos com crianças de três a quatro anos de idade, afirmam que 50\% das brincadeiras se dão com crianças do mesmo sexo, menos do que $10 \%$ delas ocorrem exclusivamente com criança de outro sexo e os restantes $40 \%$ processam-se em grupos em que estão presentes ambos os sexos. Esses dados aproximam-se dos encontrados neste estudo. Contudo, a pequena frequiência de díades e tríades mistas em Ubatuba leva-nos a pensar em uma maior segregação sexual entre essas crianças, pois é nos grupos pequenos que se processam interações mais íntimas e diretas.

\subsubsection{Síntese}

Observou-se que os meninos paulistanos participaram mais de políades do que suas colegas e que, em Ubatuba, o inverso ocorreu: meninas brincaram mais em grupos grandes do que meninos. Em contraposição, as meninas paulistanas participaram mais de tríades do que seus colegas, ao passo que o inverso ocorreu em Ubatuba, onde meninos superaram suas colegas nesse aspecto. A participação de meninos e meninas em díades foi praticamente equivalente em São Paulo e em Ubatuba. Meninos dos dois grupos culturais brincaram mais em grupos mistos do que suas colegas e as crianças de São Paulo se compuseram mais em díades e tríades mistas do que as de Ubatuba

\subsection{Participação em brincadeira}

Neste tópico, exploramos a participação diferencial de meninos e meninas dos dois grupos culturais nos diversos tipos de brincadeira, conforme a modalidade de interação e a natureza da atividade lúdica. Os estudos de brincadeira de crianças de diferentes culturas e de ambos os gêneros levam-nos a prever algumas diferenças importantes quanto ao conteúdo e freqüência das brincadeiras, mas não quanto a sua estrutura (Carvalho \& Pontes, 2003). 


\subsubsection{Tipos de interação durante a brincadeira}

Foram considerados para análise três tipos de interação (ou ausência dela) em brincadeira: comportamento observador, participação em brincadeiras não interativas (solitárias e paralelas) e em brincadeiras interativas (associativas e cooperativas ou competitivas). A MANOVA 2 × 2 calculada para testar a influência de origem e de gênero sobre comportamento observador, brincadeira não interativa e interativa não revelou efeitos principais significativos. A Figura 7.5 mostra a distribuição dos diversos tipos de brincadeira conforme o caráter da interação social nos dois grupos. Constata-se, em ambos os grupos, um predomínio das brincadeiras interativas, seguidas das não interativas, e, por último, de comportamento observador.
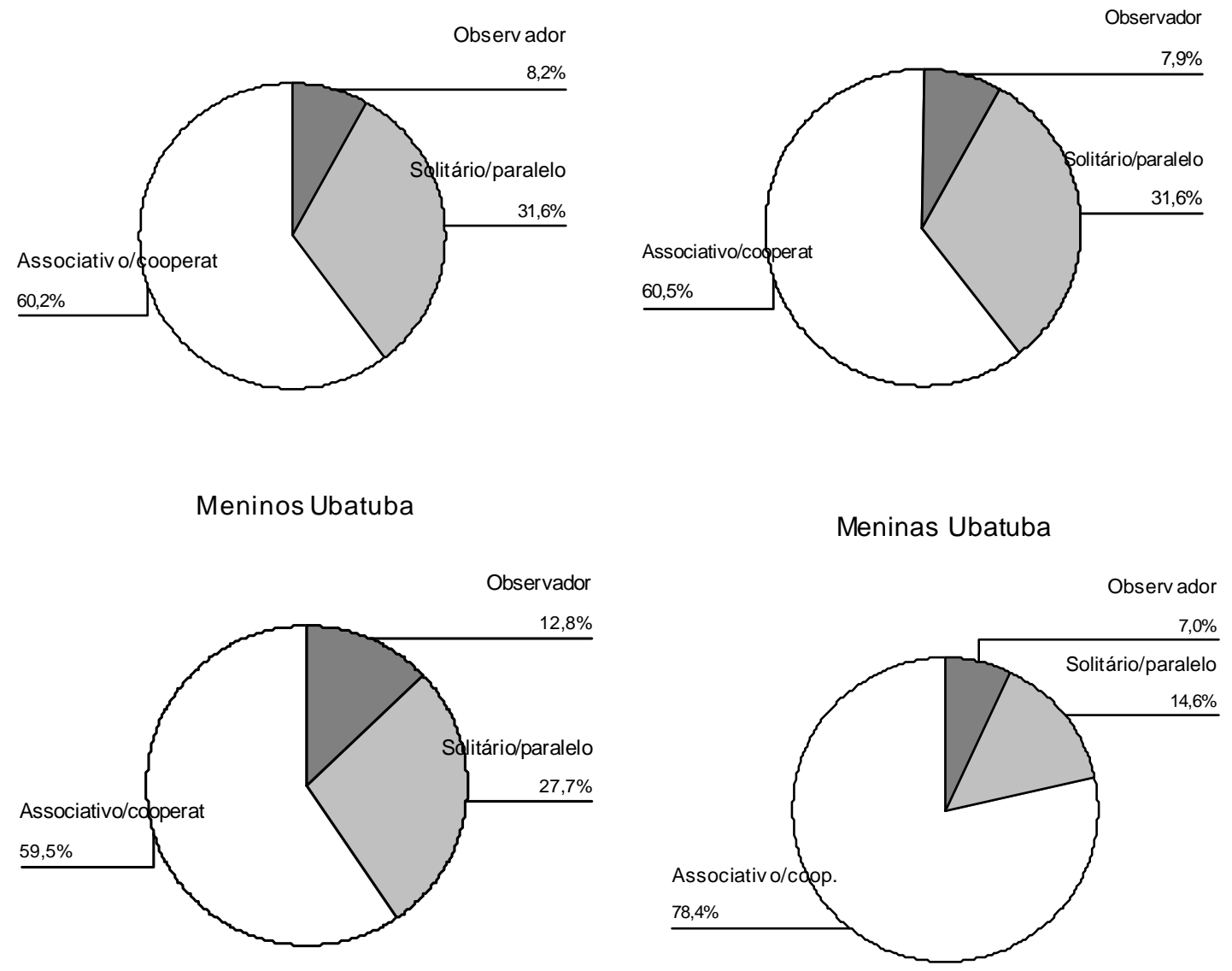

Figura 7.5. Distribuição dos tipos interação em brincadeira nas crianças dos dois grupos culturais. 
Embora não se tenham encontrado diferenças significativas em relação ao comportamento observador e a brincadeira não interativa, constatou-se que, em média, os meninos de Ubatuba passaram quase $13 \%$ de seu tempo em atividade livre observando os companheiros, contra cerca de $8 \%$ entre os meninos paulistanos, e maior proporção de seu tempo livre brincando solitariamente $(28 \%)$ do que suas colegas $(15 \%)$. Esses dados podem revelar o comportamento peculiar de alguns meninos ubatubanos, o que, em última instância, refletirse-á nas médias das categorias estudadas e nas análises estatísticas nelas baseadas. Transcrevemos, a seguir, dois exemplos de relatos de comportamento de meninos de Ubatuba que ilustram essas características e que podem revelar dificuldades na interação social.

Mat (menino) passa uma seção inteira de observação (cinco minutos) no campo de futebol segurando uma bola com o pé, sério, observando os colegas brincarem. Em outra sessão, no primeiro minuto, conversa com um colega. A seguir, senta-se e fica por dois minutos observando os companheiros e mastigando alguma coisa. No quarto minuto, levanta-se para olhar uma bicicleta que havia sido manipulada por alguns meninos. No quinto minuto, percorre o pátio observando as atividades das outras crianças.

O menino Mar, por três minutos de uma sessão, observa os colegas. No quarto, faz uma tentativa de entrar numa brincadeira, mas logo desiste e volta a observar os companheiros. Apenas no quinto minuto adere a um jogo de bola.

Em duas outras sessões, Mar passa todo o tempo brincando sozinho com a bola e, ao mesmo tempo, observando os colegas.

Nesses exemplos, assim como em outras ocasiões, tem-se a impressão de que esses meninos querem brincar, mas, seja por inibição, ou por rejeição por parte dos colegas, não conseguem engrenar numa atividade grupal. O seguinte registro de Le ilustra essa afirmação.

$1^{o}$. min. Observa meninas jogando "com quem será".

Aca (menina) pega uma bola. Le empurra a colega no chão para tirar-lhe a bola e chuta a bola para o meio de outro grupo.

$2^{o}$. min. Devolvem-lhe a bola.e Le joga-a sozinho. Anda pelo campo sozinho, chutando a bola. Ig pega-lhe a bola e joga-a para Ya. Le pega outra bola.

$3^{\circ}$. min. Senta-se em cima da bola e observa.Treina cabecear.

$4^{\circ}$. min. Tenta quicar a bola, mas esta não pula, pois está murcha.

Retém a bola e observa.

$5^{\circ}$ min. Senta-se sobre a bola e observa os colegas. 
Considerando ainda o tipo de interação em brincadeira, se tomarmos apenas o grupo de Ubatuba, constatamos também que as meninas, além de apresentarem menor frequiência de comportamento observador, também se envolveram menos em brincadeira solitária do que os meninos (Figuras 7.5 e 7.6). Coplan, Gavinski-Molina, Lagacé-Séguin e Whichmann (2001) referem que, enquanto para meninas a brincadeira solitária parece uma opção, é possível que, para os meninos, esse tipo de brincadeira seja uma resposta potencialmente mais adaptativa do que simplesmente observarem os colegas ou do que ficarem desocupados. Supõe-se que as expectativas sociais tornem menos aceitas em meninos as atitudes passivas

\subsubsection{Participação nas diversas modalidades de brincadeira, conforme gênero e grupo cultural}

Ao analisar os tipos de brincadeira de que as crianças participaram, estaremos aproximando-nos mais da caracterização da cultura do grupo de brinquedo. A Figura 7.7 mostra a distribuição dos diversos tipos de brincadeira em meninos e meninas dos dois grupos culturais. Constata-se que o tempo dedicado aos diferentes tipos de brincadeira é mais uniformemente distribuído no grupo de Ubatuba, enquanto, no grupo de São Paulo, há uma nítida preferência por brincadeiras de faz-de-conta, seguidas pelas de exercício físico e de construção. Analisandose os dois gêneros, independentemente da amostra, a diferença que mais se destaca diz respeito à inversão de tendências dos subtipos de brincadeira de contingência social: enquanto entre os meninos predominam as BTs, entre as meninas prevalecem as brincadeiras de contingência social não turbulenta (CSs). 


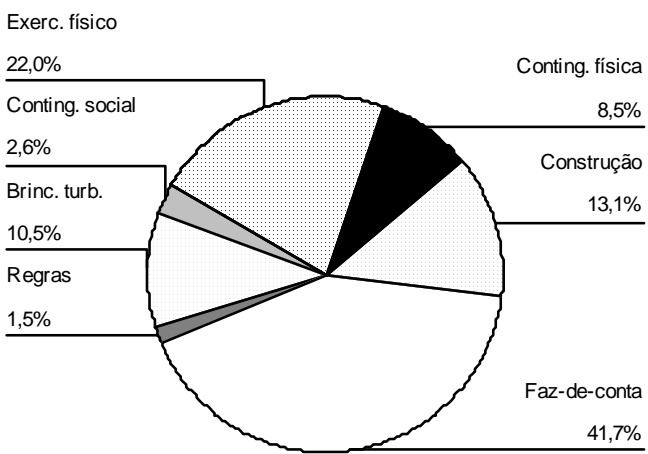

Meninos Ubatuba

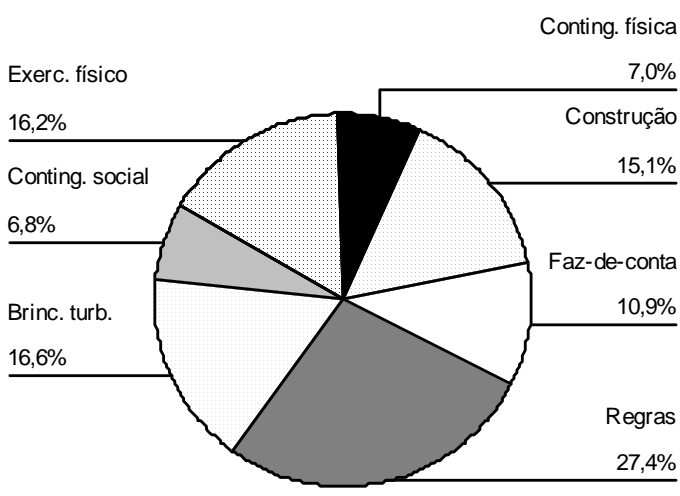

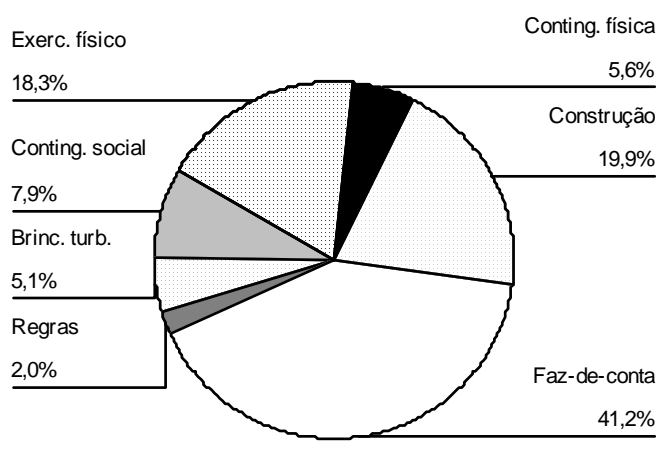

Meninas Ubatuba

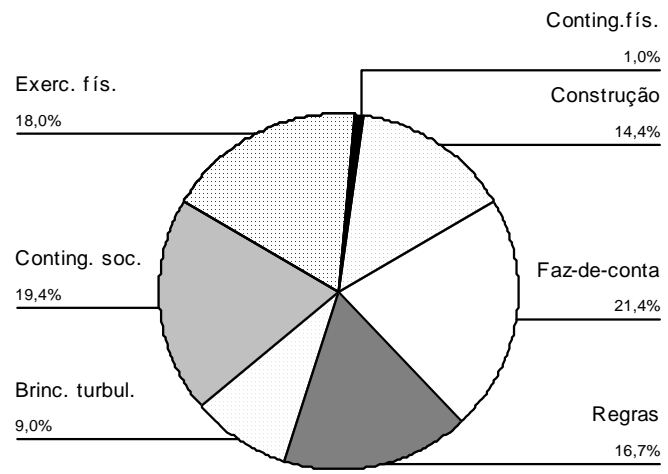

Figura 7.7. Distribuição da participação nos diversos tipos de brincadeira em meninos e meninas de São Paulo e de Ubatuba.

Calculou-se uma MANOVA 2 × 2 para testar efeito de origem e de gênero sobre a incidência das diversas modalidades de brincadeira - considerando participação em brincadeiras de exercício físico, de contingência física, de construção, de contingência social (soma de CS proximal e distal), turbulenta (soma de BT proximal e distal), de faz-de-conta e de regras, em relação ao tempo de observação. Constatou-se efeito principal significativo de origem (Lambda de Wilks $=0,362, F_{7,29}=7,294$, $\left.\mathrm{p}<0,001\right)$ e de gênero (Lambda de Wilks $=0,623, \mathrm{~F}_{7,29}=2,502$, $\mathrm{p}<0,05)$ sobre o tipo de brincadeira.

Testes univariados subseqüentes indicaram efeito significativo de origem sobre participação em brincadeiras de contingência social $\left(\mathrm{F}_{1,35}=10,361, \mathrm{p}<0,01\right)$, de faz-de-conta $\left(\mathrm{F}_{1,35}=9,532, \mathrm{p}<0,01\right)$ e de regras $\left(\mathrm{F}_{1,35}=14,204, \mathrm{p}<0,001\right)$ e marginalmente significativo 
sobre BT $\left(\mathrm{F}_{1,35}=3,191, \mathrm{p}<0,10\right)$. As crianças de São Paulo brincaram mais de faz-de-conta do que as de Ubatuba e essas, mais de regras, de BT e de contingência social (Figura 7.6).

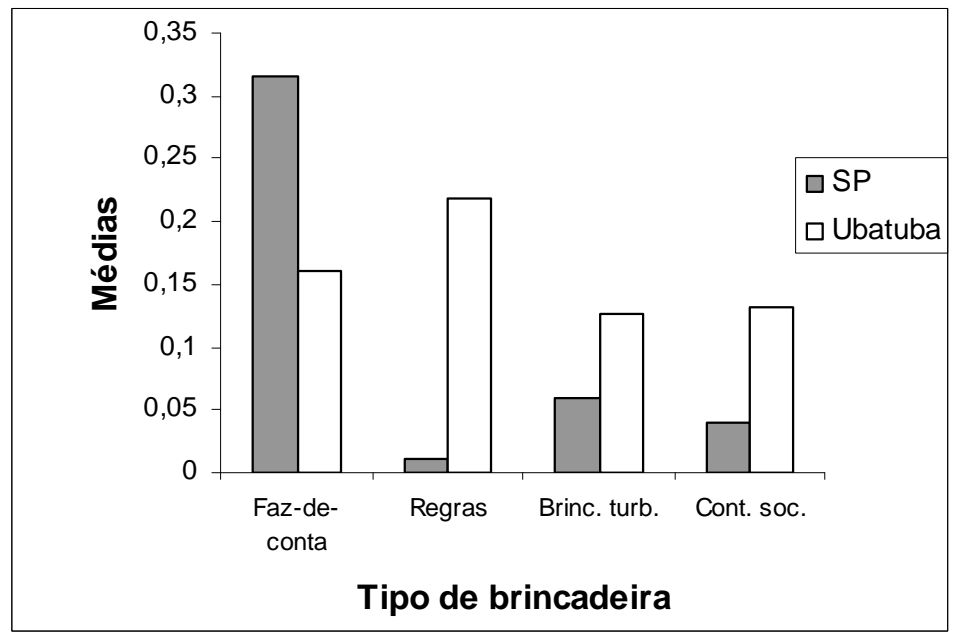

Figura 7.8. Médias de tempo gasto nos tipos de brincadeira em que houve diferenças estatisticamente significativas entre os grupos culturais.

Quanto ao gênero, observou-se efeito sobre as brincadeiras de contingência física $\left(F_{1,35}=\right.$ 4,560, $\mathrm{p}<0,05)$ e de contingência social $\left(\mathrm{F}_{1,35}=9,045, \mathrm{p}<0,01\right)$. Os meninos apresentaram mais brincadeiras de contingência física do que as meninas e elas participaram mais de brincadeiras de contingência social do que eles (Figura 7.9). Os dados apresentados nas Figuras 7.8 e 7.9 serão comentados após a descrição de algumas brincadeiras dos dois grupos.

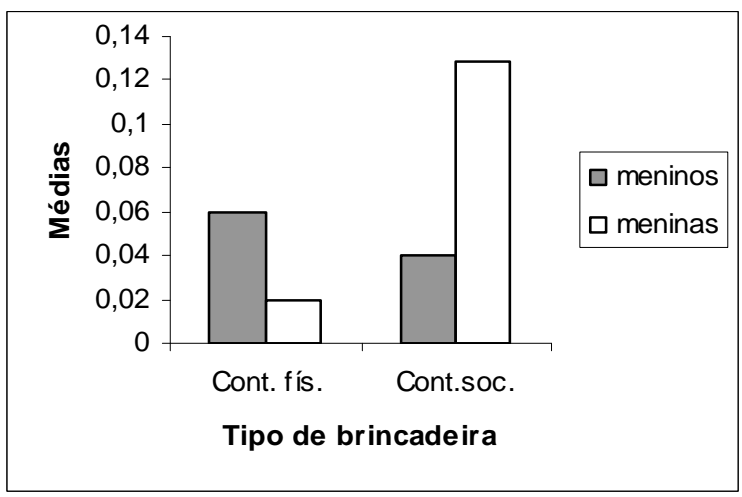

Figura 7.9. Médias de tempo gasto nas brincadeiras de contingência física e social, conforme gênero. 


\subsubsection{Brincadeiras das crianças de São Paulo e de Ubatuba}

Com vistas a exemplificar as diversas modalidades de brincadeira, a Tabela 7.1 apresenta a relação das brincadeiras classificadas nas diferentes categorias de atividade lúdica, segundo o grupo cultural a que as crianças pertenciam. As brincadeiras das crianças de Ubatuba encontram-se mais extensamente descritas por Morais e Otta (2003a).

Ao estabelecermos comparações entre as brincadeiras dos dois grupos culturais, é necessário lembrar que os materiais oferecidos para as crianças pelas duas instituições eram muito diferentes. No pátio de São Paulo, além de uma grande área descoberta com tanques de areia, trepa-trepas, gira-giras e escorregadores, havia uma área coberta em que as professoras disponibilizavam materiais para construção, como quebra-cabeças, Lego, blocos de madeiras, peças plásticas para montar, e, às vezes, lápis de cor, tinta e papel, principalmente quando o tempo estava chuvoso ou muito frio. Já em Ubatuba, quando chovia, quase nenhum aluno ia à escola e os que iam permaneciam em atividade dentro de sala de aula. Como não havia brinquedos de playground manufaturados no pátio da escola praiana, em suas atividade lúdicas, as crianças utilizavam os recursos existentes, como capim, areia, troncos e cercas. Os brinquedos disponibilizados para os alunos pela professora eram principalmente bolas, bambolês, cordas e raquetes. As crianças ubatubanas também tinham caixas de brinquedos na sala de aula que, eventualmente, a educadora permitia que fossem usadas no pátio.

As peculiaridades dos dois ambientes são sugestivas da relação dinâmica entre brincadeira e cultura: de um lado, uma oferta de diferentes materiais de acordo com concepções culturais e as preferências das crianças por determinados tipos de atividade em função de sua inserção em diferentes ambientes de criação; de outro, a apropriação peculiar que cada grupo de brincadeira faz, adaptando e criando novos materiais e atividades dentro da dinâmica propiciada pelas interações e relações interindividuais. 
Tabela 7.1. Brincadeiras observadas nos dois grupos culturais.

\begin{tabular}{|c|c|c|}
\hline Tipo & Ubatuba & São Paulo \\
\hline $\begin{array}{l}\text { Exercício } \\
\text { físico }\end{array}$ & $\begin{array}{l}\text { Correr, subir e pular de árvores, cercas ou } \\
\text { troncos; escorregar por troncos e outras } \\
\text { superfícies verticais, balançar-se em } \\
\text { galhos de árvores sustentando-se pelas } \\
\text { mãos ou montados neles; saltar em um só } \\
\text { pé; girar em torno de troncos; equilibrar-se } \\
\text { em muretas; fazer piruetas no ar; rolar no } \\
\text { chão; saltar obstáculos; rastejar; entrar e } \\
\text { sair de lugares estreitos (túneis, buracos). }\end{array}$ & $\begin{array}{l}\text { Balançar-se; dar voltas no gira-gira; subir, } \\
\text { pular de trepa-trepa; escorregar em } \\
\text { escorregador; entrar e sair de cubos, caixas } \\
\text { e tubos de concreto; saltar obstáculos; rolar } \\
\text { na areia; pendurar-se em argolas para girar } \\
\text { o corpo; subir em cercas, correr. }\end{array}$ \\
\hline $\begin{array}{l}\text { Contingência } \\
\text { física }\end{array}$ & $\begin{array}{l}\text { Fazer rolar uma bola, batê-la no chão, } \\
\text { atirá-la; executar variações de movimentos } \\
\text { com bambolê (girando-o na cintura, nos } \\
\text { braços, atirando-o para o alto); encher e } \\
\text { esvaziar recipientes; empurrar carrinhos. }\end{array}$ & $\begin{array}{c}\text { Fazer girar uma bola suspensa em barbantes } \\
\text { (brinquedo manufaturado); fazer rolar pneus; } \\
\text { chutar bola; jogar io-iô; operar brinquedos } \\
\text { manufaturados que exercitam funções } \\
\text { sensório-motoras; jogar objetos para o alto e } \\
\text { pegá-los, jogar objetos do alto para o chão; } \\
\text { empurrar e puxar objetos e brinquedos; } \\
\text { encher e esvaziar recipientes; atirar-se num } \\
\text { colchão. }\end{array}$ \\
\hline $\begin{array}{l}\text { Cont. social } \\
\text { (CS) }\end{array}$ & $\begin{array}{l}\text { Brincar de "xícara" (rodopiar em duplas, } \\
\text { com mãos dadas, frontal ou lateralmente); } \\
\text { girar sobre o corpo do outro; fazer } \\
\text { cócegas; carregar colega no colo; duas } \\
\text { crianças balançam uma terceira; montar } \\
\text { cavalinho no colega; puxar cachorrinho } \\
\text { (companheiro); bater palmas nas mãos do } \\
\text { parceiro ritmadamente; brincar de roda, } \\
\text { fazer graça para os outros. }\end{array}$ & $\begin{array}{l}\text { “Minha mãe mandou...”, “uni, duni, tre” } \\
\text { (batendo levemente na cabeça dos colegas); } \\
\text { duas crianças puxam uma terceira numa } \\
\text { caixa; fazer graça para os colegas com } \\
\text { máscaras, requebros, caretas, nomes } \\
\text { diferentes; assustar os outros; brincar com } \\
\text { palavras e variações ( "manã, manã, mimão, } \\
\text { menem, menem, menhê"); pegar colega no } \\
\text { colo; deixar cair um objeto apenas para outro } \\
\text { pegar; dançar para uma platéia, brincar de } \\
\text { trenzinho: "piiuii, abacaxi”. }\end{array}$ \\
\hline BT & $\begin{array}{l}\text { Rolar no chão com o colega; engalfinhar- } \\
\text { se; atirar bambolês, empurrar, fingir dar } \\
\text { soco, chutar o companheiro; duas crianças } \\
\text { dentro do mesmo bambolê puxam-no em } \\
\text { direções opostas; jogar capim, areia no } \\
\text { outro; brincar de perseguição e fuga. }\end{array}$ & $\begin{array}{c}\text { Brincar de perseguição e fuga, atirar objetos } \\
\text { ou areia no outro; bater no outro com objeto } \\
\text { leve; duas crianças fazem rolar um caixote } \\
\text { com um colega dentro; rolar, engalfinhar-se, } \\
\text { chutar, segurar com força, dar soco no } \\
\text { colega. }\end{array}$ \\
\hline Construção & $\begin{array}{l}\text { Fazer montes de areia, capim e de } \\
\text { pedrinhas, perfurar buracos; desenhar na } \\
\text { areia, usar forminhas para modelar areia; } \\
\text { montar blocos, quebra-cabeças, colar } \\
\text { figuras. }\end{array}$ & $\begin{array}{l}\text { Usar fôrmas para modelar areia; cavar e } \\
\text { amontoar; desenhar na areia, desenhar, } \\
\text { pintar com lápis ou pincel; montar, } \\
\text { empilhar, encaixar peças plásticas, de } \\
\text { madeira montar quebra-cabeças; modelar } \\
\text { massinha. }\end{array}$ \\
\hline Regras & $\begin{array}{l}\text { Pato-ganso; pega-pega; pular corda; usar } \\
\text { corda como obstáculo; cabra-cega; cabo de } \\
\text { guerra; jogar raquete; chutar bola/ futebol; } \\
\text { queimada; jogar bola com as mãos, corrida } \\
\text { de saco. }\end{array}$ & $\begin{array}{c}\text { Pega-pega; futebol; telefone sem fio, } \\
\text { futebol, batata-quente, dança em volta das } \\
\text { cadeiras (brincadeiras coordenadas pelas } \\
\text { educadoras). }\end{array}$ \\
\hline Desafio físico & $\begin{array}{l}\text { Subir muito alto e pular; andar de um só } \\
\text { pé em superfícies estreitas; carregar } \\
\text { objetos pesados (troncos), correr dentro de } \\
\text { saco. }\end{array}$ & $\begin{array}{l}\text { Colocar-se de ponta-a-cabeça; balançar-se } \\
\text { com intensidade, em pé, com a barriga para } \\
\text { baixo; subir rampas inclinadas; equilibrar-se, } \\
\text { subir alto, pular do alto; girar com vigor, } \\
\text { rodar em pé no gira-gira. }\end{array}$ \\
\hline
\end{tabular}


A oferta diferencial de brinquedos pode em si traduzir a maior valorização cultural de certas atividades. Os pais de classe média de São Paulo, ainda mais em se tratando de um grupo que convive numa universidade, provavelmente, valorizam sobremaneira o desenvolvimento da coordenação motora fina e do raciocínio abstrato e lógico-matemático, assim como a aquisição precoce de conhecimentos e habilidades que irão facilitar o desempenho escolar e que prepararão os filhos para uma vida acadêmica e profissional altamente competitiva e especializada. Supõe-se que a preparação acadêmica não seja tão valorizada pela classe trabalhadora de Ubatuba, tendo em vista a adoção de um modo de vida mais simples para o qual as crianças são preparadas. Devem-se ressalvar, obviamente, algumas exceções encontradas entre as famílias em que os valores de ascensão social predominam.

Outro aspecto circunstancial diferenciava as duas escolas: a própria concepção de préescola para os pais. Supõe-se que, para as famílias de São Paulo, a escola é, além de um precursor indispensável da educação escolar formal, uma necessidade dos pais que, em geral, não têm com quem deixar os filhos enquanto trabalham. Nessa perspectiva, a escola é um importante continuador dos cuidados e da educação informal das crianças. Por sua vez, conversas informais com os pais de Ubatuba nos sugeriram que freqüentar a escola é, para eles, um sinal de status e um privilégio oferecido às crianças, uma vez que os cuidados diários poderiam ser confiados a irmãos mais velhos, avós, tios e vizinhos. Tendo em vista essas considerações preliminares, teceremos alguns comentários sobre a participação diferencial dos dois grupos nas diferentes modalidades de brincadeira.

Brincadeiras de exercício físico. Quanto ao exercício da coordenação motora global, incluído nas brincadeiras de exercício físico, as atividades realizadas pelos dois grupos, bem como sua incidência, foram muito semelhantes. Embora as crianças de Ubatuba se exercitassem com o apoio de recursos naturais, como árvores e troncos, as de São Paulo executavam ações semelhantes nos brinquedos grandes de playground. Contudo, é necessário ressalvar que, na época dos registros, brinquedos manufaturados de playground estavam sendo pleiteados pela direção da escola de Ubatuba - o que indica que eram também valorizados naquele ambiente. A realização de atividades físicas, tanto em Ubatuba quanto em São Paulo, por meninos e por meninas, pareceu-nos altamente motivadora para as crianças (Figura 7.10). Sua importância é óbvia, considerando-se suas implicações para um desenvolvimento físico saudável, essencial para as crianças de todos os grupos sociais. 
Brincadeiras de contingência. Tendo em vista o caráter predominantemente interacional das brincadeiras de contingência social, os dados encontrados e apresentados nas Figuras 7.7 e 7.8 e 7.9 são coerentes com aqueles verificados na literatura, que demonstram que meninas são mais preocupadas com as relações interpessoais, especialmente as solidárias e simétricas (Belle, 1989; Lansford \& Parker, 1999). Já em relação às brincadeiras de contingência física, em que as crianças testam efeitos sobre objetos, o resultado também está dentro do esperado, tendo em vista o caráter mais ativo dos meninos, que lançam, atiram, fazem rolar bolas, pneus e outros objetos. Observe-se que tais brincadeiras estão relacionadas com o fazer, mais do que com o relacionar-se, fato que também diferencia o gênero masculino do feminino (Fabes, Martin \& Hanish, 2003; Martin \& Fabes, 2001).

Um dos achados mais intrigantes deste trabalho diz respeito à alta incidência de brincadeiras turbulentas (BTs) e de contingência social (CSs) entre as crianças de Ubatuba. A freqüência de BT entre os meninos ubatubanos (que ocuparam cerca de $17 \%$ do tempo de observação e de $20 \%$ do tempo de brincadeira) excede em muito aquela descrita por Pellegrini e Smith (1998) - que relatam um incidência de 3\% a 5\% dessas brincadeiras em pré-escolares e de $7 \%$ a $8 \%$, em meninos de seis a dez anos de idade -, cujos dados se aproximam mais daqueles verificados entre os meninos de São Paulo. Quanto às brincadeiras de contingência social não turbulentas, encontra-se pouquíssima referência na literatura.

A incidência semelhante de brincadeiras de CS entre meninas (Figura 7.11) e de BT entre meninos é sugestiva de uma semelhança de função entre as duas. Parker (1984) considera que, em ambas, é forte a motivação de produzir repostas contingentes no outro. Em relação à BT, mais estudada, discute-se sua importante função no revezamento de papéis, no exercício do autocontrole e no desenvolvimento da percepção do outro. A diferença encontrada entre os gêneros é compatível com o caráter mais íntimo das relações entre meninas e mais ativo e hierárquico (estabelecido com base em relações de dominância e de submissão) entre os meninos (Belle, 1989; Harris, 1998). A seguir, examinaremos o caráter distal e proximal das brincadeiras de contingência social turbulentas e não turbulentas, para verificar a forma como se processam as relações nesses tipos brincadeira nos dois grupos culturais e gêneros.

A MANOVA 2 × 2 calculada para avaliar efeito de origem e de gênero sobre a participação nas quatro categorias de brincadeiras de contingência social (BT proximal e distal e CS proximal e distal) relativizada em razão do tempo de observação revelou influência de origem sobre a participação em CSs proximais $\left(\mathrm{F}_{1,35}=11,762, \mathrm{p}<0,01\right)$, CSs distais $\left(\mathrm{F}_{1,35}=\right.$ 4,157, $\mathrm{p}<0,05)$ e em BTs proximais $\left(\mathrm{F}_{1,35}=5,636, \mathrm{p}<0,05\right)$. Constatou-se que as crianças de 
Ubatuba se envolveram mais nos dois tipos de brincadeiras proximais do que as de São Paulo (Figuras 7.12 e 7.13). Encontrou-se efeito significativo de gênero (Lambda de Wilks = 0,456, $\left.\mathrm{F}_{4,32}=3,647, \mathrm{p}<0,05\right)$ e de origem (Lambda de Wilks $=0,639, \mathrm{~F}_{4,32}=4,522, \mathrm{p}<0,01$ ) sobre a participação nessas brincadeiras. Testes univariados subseqüentes indicaram efeito de gênero sobre a participação em CSs proximais $\left(\mathrm{F}_{1,35}=6,704, \mathrm{p}<0,05\right)$ e distais $\left(\mathrm{F}_{1,35}=4,157, \mathrm{p}<0,05\right)$ e em BTs proximais $\left(\mathrm{F}_{1,35}=4,178, \mathrm{p}<0,05\right)$. Meninos apresentaram mais BTs proximais e meninas participaram mais de brincadeiras de contingência social, tanto proximais quanto distais. (Figura 7.14).

A maior incidência de brincadeiras de caráter proximal entre as crianças ubatubanas está de acordo com os dados obtidos por Lee Manoel et al. (2003), que encontraram maior frequiência de contato físico entre as crianças de Ubatuba do que entre as paulistanas. Tais fatos podem indicar que a cultura ubatubana se caracteriza pelo modo de contato mais proximal e a paulistana, pelo modo mais distal e verbal.

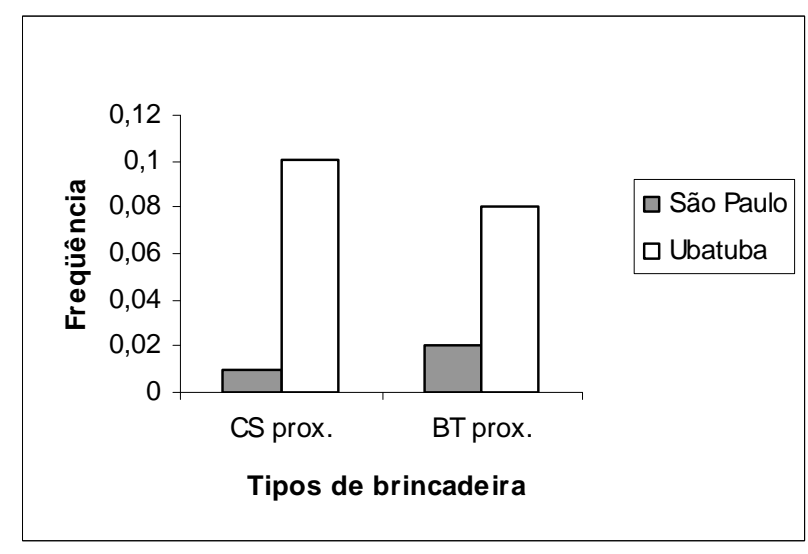

Figura 7.13. Tipos de brincadeira de contingência social que diferiram significativamente entre os grupos culturais. 


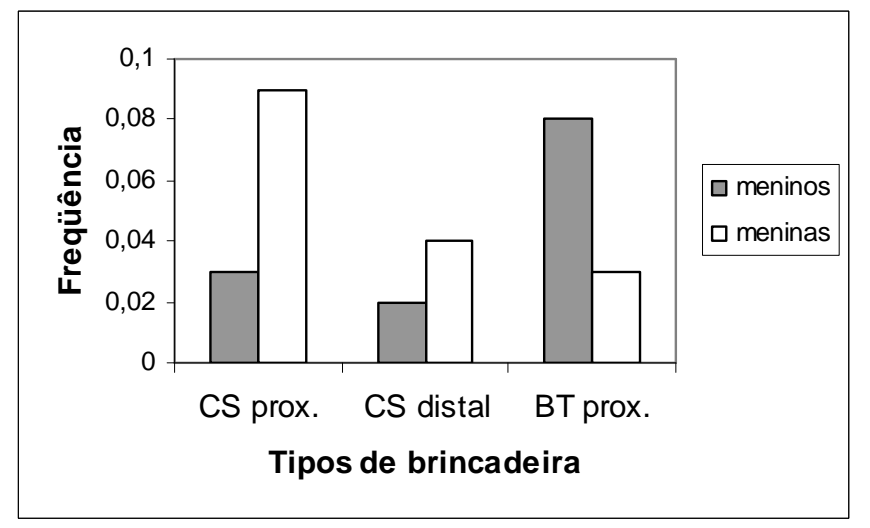

Figura 7.14. Tipos de brincadeira de contingência social que diferiram significativamente entre os gêneros.

Confirmam-se, desse modo, inúmeros estudos que indicam que os meninos se envolvem mais do que as meninas em BTs proximais, com simulação de luta física, envolvendo socos, pontapés e engalfinhamento (Pellegrini, 1993, 1995; Pellegrini \& Smith, 1998; Souza \& Rodrigues, 2002). Embora esperássemos que, dadas as relações mais próximas estabelecidas nas brincadeiras de contingência social, essas prevalecessem entre as meninas, não há praticamente estudos que usem essa categoria para descrever brincadeiras entre pares e que possam servir de parâmetro para comparar nossos dados. Não se constataram diferenças significativas entre os gêneros na participação em BTs distais, principalmente de luta, perseguição e fuga - o que pode revelar que o que realmente diferencia meninos e meninas nesse tipo de brincadeira contingente são os contatos através de socos, pontapés e engalfinhamento, presentes praticamente apenas no grupo masculino.

Smith e Pellegini (no prelo) consideram que as BTs constituem importante exercício das habilidades requeridas para a luta, necessárias não apenas para a resolução dos conflitos intergrupais, mas também para o estabelecimento e manutenção de status social e para o conseqüente sucesso reprodutivo de indivíduos do sexo masculino. Gosso et al. (no prelo), ao constatarem pequena incidência de BTs proximais entre os índios Parakanã, expressam opinião diferente. Na visão dos autores, as BTs, tão importantes para outros animais, perderam a relevância para a espécie humana. Conforme afirma Gosso (comunicação pessoal), é também pequeno o nível de conflito entre os índios Parakanã, que enfatizam valores de solidariedade e modéstia. É provável, então, que, nesse grupo, as brincadeiras turbulentas não sejam incentivadas como meio de estabelecimento de hierarquia de dominância. A maior incidência de 
BTs proximais entre as crianças ubatubanas, quando comparadas às paulistanas, é também indicativa da importância que fatores culturais exercem sobre a atividade lúdica. Evidencia-se, assim, mais uma vez o diálogo entre a cultura e a brincadeira. Adultos oferecem para a criança o que é valorizado pela cultura e ela apropria-se dos conteúdos de uma forma que lhe é peculiar como criança, como criança de uma determinada cultura e como participante de um determinado grupo de brincadeira.

Brincadeiras de construção. A incidência dessas brincadeiras foi bastante semelhante entre meninos e meninas dos dois grupos culturais (ocorrendo entre 12 e $15 \%$ do tempo de observação). Note-se que as brincadeiras e jogos de construção exercitam um conjunto de funções motoras e cognitivas, o que é certamente essencial para o desenvolvimento. A execução requer planejamento e o produto final é dotado de simbolismo e de representação. Essas brincadeiras assemelham-se ao trabalho produtivo e à produção artística. Modelagens, colagens, pinturas podem resultar em produções artísticas, enquanto montagens, construções, encaixes assemelham-se a trabalhos que requerem coordenação motora e raciocínio espacial. Poucos foram os estudos que se dedicaram ao tema. No presente trabalho, não analisamos especificamente os tipos de produção de cada grupo e subgrupo, mas, se o fizermos, certamente diferenças importantes serão encontradas. Percebe-se que as crianças de Ubatuba utilizam mais materiais naturais em suas construções, talvez pela pequena oferta de elementos propositadamente planejados para esse fim, em contraste com a grande oferta de brinquedos prontos para as crianças paulistanas: quebra-cabeças, blocos e peças plásticas de montagem e elementos que propiciam a representação gráfica.

Brincadeiras de faz-de-conta. Foi grande a diferença observada de participação em brincadeiras de faz-de-conta entre os dois grupos culturais e gêneros: brincadeiras simbólicas foram muito mais freqüentes entre as crianças paulistanas. Dados semelhantes aos constatados em relação às crianças ubatubanas - grupo em que a participação em brincadeiras simbólicas apresentou freqüência equivalente à encontrada em outras modalidades de brincadeira - foram verificados entre crianças indígenas (Gosso et al., 2002) e entre crianças de classes socioeconômicas menos favorecidas (Fein, 1981; Gosso et al., 2002). Mesmo considerando que a relativa proporcionalidade das atividades lúdicas dá-se segundo os critérios de classificação adotados no presente estudo - que é apenas uma das formas de categorizar as brincadeiras -, em relação às brincadeiras de faz-de-conta, há um consenso de 
definição por parte de praticamente todos os autores que a estudaram (Bichara, 2002; Farver \& Shin, 1997; Fein, 1981; P.K. Smith, 2002).

Uma possível explicação para o fato de as crianças das classes média e alta das sociedades modernas dedicarem tanto tempo às brincadeiras imaginativas é a supervalorização do pensamento simbólico e abstrato por parte da cultura da classe média da grande metrópole. Provavelmente, as crianças ubatubanas são menos incentivadas a exercitar o pensamento simbólico do que as paulistanas, que têm maior acesso a produtos culturais, como filmes, peças de teatro, livros e revistas. Além disso, supõe-se que, no grupo de São Paulo, haja maior valorização da expressão dos sentimentos pessoais e da expressão figurada por meio de conversas e da produção artística. Por sua vez, as crianças ubatubanas vivem em um ambiente em que, possivelmente, as soluções imediatas para problemas concretos são mais solicitadas. A favor dessa hipótese, encontra-se a constatação de que a distribuição de tempo dedicado aos diversos tipos de brincadeira é mais eqüitativa no grupo de Ubatuba. Pode-se, ainda, conjecturar que as demandas de circunstâncias de vida muito afastadas daquelas de nosso ambiente de adaptação - que levam a uma supervalorização da intelectualização e à criação arbitrária de um mundo novo, transformado pelo homem - produzam um efeito de induzir a criança a afastar-se da realidade concreta, da qual ainda estão mais próximas as classes trabalhadoras.

Uma explicação alternativa para a diferença de freqüência de brincadeira imaginativa entre os dois grupos culturais implica o pressuposto de que a falta de estimulação do ambiente ubatubano seja apenas aparente, escondendo as oportunidades preciosas de desenvolvimento de que dispõem as crianças da praia: maior contato com a natureza e com as matas nativas; montanhas, árvores, rios, cachoeiras, praias e mar para explorarem. O ambiente desafiador no qual vivem essas crianças poderia reduzir sua tendência a realizar desejos através da fantasia. Essa interpretação é também consistente com os achados de Gosso et al. (2002), que constataram poucos temas fantásticos nas brincadeiras simbólicas dos índios Parakanã. Pode-se considerar que um contexto mais semelhante ao do ambiente de adaptação evolucionária forneça oportunidades únicas de desenvolvimento para as crianças. A oportunidade de conviver com companheiros de idades diferentes e com vários adultos dá às crianças ubatubanas diversas alternativas de interação. Citamos como exemplo a maternagem, que envolve a habilidade de reconhecer e assumir a perspectiva do outro e que ocorre mais provavelmente em interação com crianças mais novas (Carvalho \& Beraldo, 1989). 
Outra explicação do mesmo fato, de ordem mais cognitiva, é proposta por McLoyd, (1983) e por Striano, Tomasello e Rochat (2001). Segundo esses autores, os brinquedos em miniatura - muito presentes na creche de São Paulo - teriam forte poder indutor da brincadeira de faz-de-conta. Como as crianças de Ubatuba foram mais privadas desses brinquedos, teriam de recorrer a estímulos menos estruturados e, portanto, mais à sua criatividade para transformar simbolicamente objetos e situações. Acreditamos que o mais provável é que haja uma interação entre todos os fatores citados na determinação de diferenças culturais na incidência da brincadeira simbólica.

Em relação ao conteúdo das brincadeiras de faz-de-conta, transcrevemos os resultados descritos por Morais e Otta (2003b), que compararam a brincadeira simbólica destes dois grupos culturais. As autoras constataram efeitos de origem e de gênero sobre os conteúdos das brincadeiras: as crianças de São Paulo simularam mais atividades de cuidados pessoais, temas fantásticos e brincaram mais de luta e perseguição do que as de Ubatuba e essas, mais atividades de animais do que as de São Paulo. As meninas simularam mais atividades diárias e de cuidado com o outro do que os meninos e esses brincaram mais de luta, perseguição e fuga do que elas (Tabela 7.2).

Tabela 7.2. Média e erro padrão de conteúdos de faz-de-conta de acordo com o grupo cultural e gênero.

\begin{tabular}{l|cccc|cccc}
\hline Temas & \multicolumn{3}{|c}{ São Paulo } & \multicolumn{2}{c|}{ Ubatuba } & \multicolumn{2}{c}{ meninos } & \multicolumn{2}{c}{ meninas } \\
& Média & EP & Média & EP & Média & EP & Média & EP \\
\hline Cuidados com o outro & $.21_{\mathrm{a}}$ & .04 & $.06_{\mathrm{b}}$ & .03 & $.00_{\mathrm{a}}$ & .04 & $.27_{\mathrm{b}}$ & .04 \\
Atividades de vida diária & $.12_{\mathrm{a}}$ & .05 & $.12_{\mathrm{a}}$ & .05 & $.04_{\mathrm{a}}$ & .05 & $.21_{\mathrm{b}}$ & .05 \\
Fantásticos & $.13_{\mathrm{a}}$ & .04 & $.00_{\mathrm{b}}$ & .02 & $.11_{\mathrm{a}}$ & .04 & $.03_{\mathrm{a}}$ & .02 \\
Luta, perseg. e fuga & $.35_{\mathrm{a}}$ & .08 & $.10_{\mathrm{b}}$ & .07 & $.33_{\mathrm{a}}$ & .08 & $.12_{\mathrm{b}}$ & .08 \\
Atividades de animais & $.000_{\mathrm{a}}$ & .09 & $.32_{\mathrm{b}}$ & .08 & $.14_{\mathrm{a}}$ & .08 & $.19_{\mathrm{a}}$ & .08 \\
\hline
\end{tabular}

Observe-se que, se as BTs proximais foram mais freqüentes entre os meninos ubatubanos, as atividades de luta, perseguição e fuga no contexto de faz-de-conta (heróis versus 
bandidos, policia versus ladrão) tiveram maior incidência entre as crianças paulistanas, indicando uma forma de compensação por substituição de brincadeiras de caráter semelhante. Esse dado pode estar relacionado com a maior tendência de expressão de desejos e de intenções no plano simbólico por parte dos meninos paulistanos e com a forma mais direta de manifestação dos mesmos desejos e intenções por parte dos ubatubanos.

Os dados encontrados em relação aos temas são coerentes com diversos estudos que constataram que meninos tendem a brincar mais de temas fantásticos e meninas, de temas mais próximos de seu cotidiano (Bichara, 2002; Fein, 1981; Morais e Carvalho, 1994). A grande incidência de brincadeiras relativas a atividades de animais em Ubatuba (principalmente cachorros e cavalos) pode dizer respeito ao maior contato dos ubatubanos com animais domésticos. Entretanto, deve-se considerar que esse fato também possa ser explicado por um modismo temporário do grupo de brincadeira.

Brincadeiras de regras. No que diz respeito aos jogos de regras, verificaram-se grandes diferenças entre os dois grupos culturais. Em São Paulo, além de serem constatadas poucas brincadeiras desse tipo, observou-se que as crianças aderiam a elas por períodos curtos. Por exemplo, as brincadeiras propostas pelas educadoras, de telefone sem fio ou dança das cadeiras, eram abandonadas logo que a educadora se afastava. É certo que as crianças ubatubanas eram, em média, cinco meses mais velhas do que as paulistanas, o que, em parte, pode explicar um maior interesse delas pelos jogos de regras, típicos de uma fase posterior do desenvolvimento. Entretanto, o grande envolvimento dos meninos ubatubanos em jogos de bola e de tênis de praia leva-nos a conjecturar a favor de influências ambientais e culturais. Ao lado da existência de regras, tais brincadeiras têm um grande componente de exercício físico, que, provavelmente, além de ser fortemente valorizado pela cultura praiana, é facilitado pelo grande e diversificado espaço que os ubatubanos têm para brincar. Tais jogos são também muito freqüentes em outras sociedades mais simples e tradicionais, como as de vários grupos indígenas (Gosso et al., no prelo). Jogos competitivos que representam arremessos de projétil contra o campo inimigo (futebol e tênis de praia) e que, ao mesmo tempo, exercitam o corpo podem indicar a importância que adquirem para o grupo praiano os atributos de força física e a defesa do território (Parker, 1984). Apesar de corrermos o risco de extrapolar excessivamente os dados, devemos sugerir que a questão de defesa do território - que pode estar relacionada com os jogos de ataque e defesa - é muito importante para os caiçaras, em razão da perda de terras - real ou 
simbólica - para os turistas, exploradores imobiliários e "grileiros" (pessoas que se apossam indevidamente de terras).

Certas peculiaridades dos jogos de regras dos ubatubanos merecem destaque. Algumas "partidas" de futebol eram jogos simples, em que duas ou três crianças participavam: uma delas era goleiro e a(s) outra(s) tentavam fazer gols. Apesar de simples, tais jogos eram tumultuados por desentendimentos em relação ao número de gols e a quem estava vencendo. De algumas partidas participava um número maior de crianças, que tentavam chegar ao gol driblando e ultrapassando os companheiros. As regras não eram claras e as disputas, freqüentes. Não foi observado nenhum jogo de futebol em que se pudesse identificar claramente a organização de times adversários (Figura 7.15). Piaget (1945/1975) também se refere à mesma desorganização aparente nos jogos de regras de crianças européias de idade semelhante. Já a brincadeira de tênis de praia, que, em geral, reunia dois contendores, revelava regras mais claras, e, apesar de as habilidades das crianças não permitirem uma partida fluente, o que parecia mais importante no jogo era procurar não interromper a atividade. Exemplificamos abaixo esses comentários.

Futebol:

1) Quatro meninos jogam bola (é impossível descobrir quem são os times adversários).

Yn está no gol. Ig chuta a bola e grita: goool!

Ig-Aqui! Relou, relou. É nossa.

Ya (do mesmo "time") - É nossa.

Yn-Gol do goleiro!

Ya-É nossa!

Ig-É nossa!

2) Yn joga a bola para Fe.

$\mathrm{Fe}$ - Vou fazer gol!

Yn chuta e diz: Golaço!

Fala a Gai (que está passando): Estou com quatro (pontos).

Fe chuta e grita: gool!

Yn diz a Fe: Nem foi.

Yn pega outra bola, chuta a Fe e grita: Gool! Agora tou com cinco.

Chuta novamente e declara: Agora tou com seis.

$\mathrm{Fe}-\mathrm{Não}$ tá.

Fe joga a bola no pé de Yn. Yn defende, jogando-a longe de Fe, que vai pegar a bola no mato.

Fe chuta para Yn e grita: Gol, Yn!

Yn-Nem foi. 
Tênis de praia - episódio de cinco minutos:

Ya e Yn jogam, usando como bola uma cabeça da boneca Magali.

Ya joga bola. Yn não pega.

Ya: É vesgo!

Yn - Eu fiz assim (joga a cabeça da Magali com raquete).

Yn erra, pois joga a "bola" muito longe de Ya. Este não consegue rebater.

Yn atira novamente a bola.

Ya erra e diz: Caralho! e pula, mostrando a Yn como pulou.

Diz a Yn: Cê num taca essa. Ri de Yn quando esse erra.

Quando é ele (Ya) quem erra, também ri, sem graça.

Yn ri de Ya e esse aparentemente não dá importância. Ambos riem.

Chega outra criança para assistir ao jogo.

Ya consegue rebater a bola e Yn diz: ó, o Ya, cara!

Desafio de limites.. Destacamos neste tópico as brincadeiras de exercício físico em que as crianças davam claras demonstrações de que estariam tentando melhorar suas habilidades, ultrapassando seus limites. A tentativa de desafiar limites foi uma prática relativamente constante durante as brincadeiras. No entanto, ao passo que as crianças de São Paulo ostentavam claramente sua performance e habilidade para os colegas e adultos, em Ubatuba, o comportamento de exibição esteve praticamente ausente. Exemplo de um episódio observado em São Paulo, envolvendo duas meninas (Re e Yo).

Re - Eu vou fazer uma coisa ... só que é perigosa!

Yo - Eu vou fazer uma coisa perigosa!

Re sobe numa das barras horizontais do trepa-trepa, encaixa as pernas e deixa cairo tronco e a cabeça para baixo.

Yo faz o mesmo, com menos agilidade, menos perícia e sem soltar tanto o tronco.

Re (após ficar certo tempo com a cabeça para baixo) - Doeu minhas mãos!

Re descansa um pouco e, em seguida, torna a colocar-se de cabeça para baixo.

Yo imita-a com menos desenvoltura.

Re - Eu sei fazer uma coisa muito perigosa. Tenho que pôr o pé aqui e aqui (indica duas barras horizontais, separadas por uma vertical).Coloca as pernas em cada uma das barras e joga o tronco e a cabeça para trás.

Re - Olha que coisa perigosa! Ajeita-se e pendura-se mais duas vezes de cabeça para baixo.

Yo a imita, desajeitadamente.

Apesar da pequena freqüência de episódios deste tipo, a ANOVA aplicada para testar efeito de origem e de gênero sobre a ocorrência de desafios físicos indicou efeito significativo 
de origem $\left(\mathrm{F}_{1,35}=3,891, \mathrm{p}=0,05\right)$, tendo as crianças de São Paulo exibido mais esse tipo de comportamento do que as de Ubatuba (Figura 7.16).

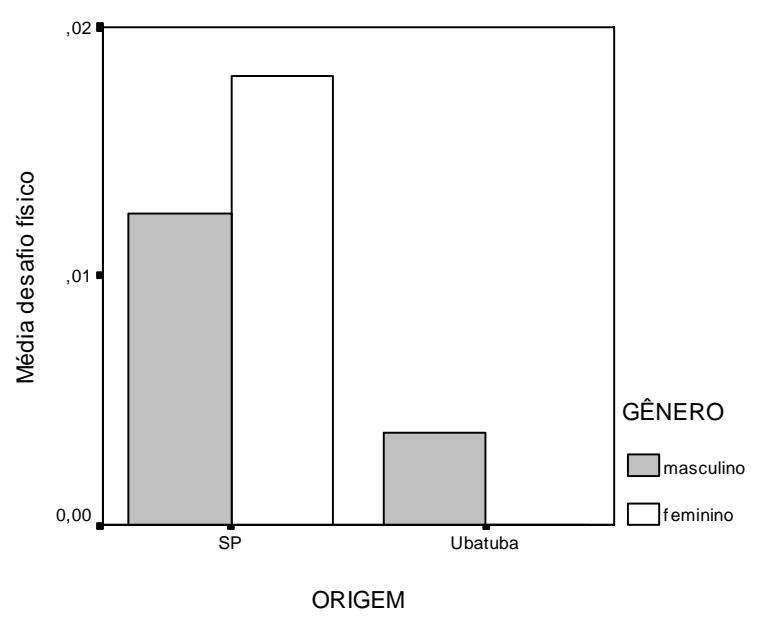

Figura 7.16. Médias de episódios de desafio físico acompanhados de exibição em relação ao tempo total de observação, segundo origem e gênero.

O desafio físico, como foi definido neste trabalho, apresenta um componente adicional às situações em que as crianças testam os limites de suas possibilidades, pois traz uma característica social de ostentação das habilidades físicas. Talvez, por isso, tenhamos encontrado diferenças entre os dois grupos culturais. Enquanto, para as crianças de Ubatuba, vencer os desafios físicos parece uma tarefa mais "natural", ou seja, que não necessita de tanto reconhecimento por parte dos parceiros e adultos, para as crianças de São Paulo, vencer certas barreiras físicas é motivo de orgulho e de exibição.

\subsubsection{Síntese}

No que concerne à participação nas diversas modalidades de brincadeira, verificaram-se tanto semelhanças quanto diferenças entre os dois grupos culturais e entre meninos e meninas. As principais semelhanças evidenciam-se ao se examinar a natureza dos diversos tipos de brincadeiras, conforme descritas na Tabela 7.1. Entretanto, quando se analisa a distribuição delas no tempo de observação, constatam-se diferenças substanciais. Talvez a mais notória diga respeito ao contraste entre a ocorrência uniforme das diversas modalidades de brincar entre as 
crianças ubatubanas e ao predomínio de brincadeira de faz-de-conta entre as paulistanas. Outros contrastes importantes foram as altas incidências de jogos de regras entre as crianças ubatubanas, mormente entre os meninos, e de brincadeiras de contingência social turbulentas e não turbulentas no grupo de Ubatuba, quando comparado ao de São Paulo.

Esses dados reforçam as peculiaridades de cada microcultura de grupo de brincadeira e remetem-nos a considerar também diferenças culturais no estilo de criação. Examinando-se a alta incidência de brincadeira imaginativa nas crianças de São Paulo, pode-se supor que a cultura adulta em que se inserem enfatize o pensamento simbólico, enquanto a maior frequiência de brincadeiras de contingência social verificada nas crianças de Ubatuba pode estar relacionada com uma cultura que enfatize o valor da interação com o outro. $\mathrm{O}$ mesmo pode ser dito quanto ao caráter proximal/distal das brincadeiras de contingência: brincadeiras envolvendo contato corporal prevaleceram entre as crianças ubatubanas.

As principais diferenças de gênero encontradas - maior ocorrência de brincadeiras de contingência social entre as meninas e de contingência física entre os meninos - apontam na direção de uma microcultura de gênero em que a reciprocidade e o interesse nas relações sociais revelou-se uma característica mais feminina e o efeito sobre os objetos, um atributo mais masculino.

\subsection{Algumas associações entre os índices}

Nesta sessão, buscamos relacionar algumas medidas encontradas nos itens anteriores. Procuramos primeiro verificar como as diversas modalidades de brincadeira se associaram com a composição de grupos segundo o gênero das crianças. Em seguida, analisamos as relações entre modalidades interacionais e a natureza das brincadeiras e, ao final, verificamos possíveis correlações entre os diversos tamanhos de grupo e o caráter das brincadeiras.

\subsubsection{Participação nos diversos tipos de brincadeira quanto à composição do grupo}

Para comparar a participação nos diversos tipos de brincadeira em relação à composição do grupo, apurou-se inicialmente a ocorrência de grupos mistos e de mesmo sexo nas diferentes modalidades de brincadeira. Em seguida, os dados foram relativizados, calculando-se a participação do sujeito focal em cada modalidade de brincadeira em grupos mistos e de mesmo sexo, em razão da participação total no mesmo tipo de brincadeira.

A MANOVA efetuada para avaliar efeitos de origem e de gênero sobre os diversos tipos de brincadeira observados em grupos de mesmo sexo e mistos revelou efeito significativo de 
origem (Lambda de Wilks $=0,322, \mathrm{~F}_{14,22}=3,314, \mathrm{p}<0,01$ ) e de gênero (Lambda de Wilks $=$ $\left.0,390, \mathrm{~F}_{14,22}=2,455, \mathrm{p}<0,05\right)$. Análises univariadas subseqüentes indicaram efeito de origem sobre brincadeira de contingência física mista $\left(\mathrm{F}_{1,35}=8,544, \mathrm{p}<0,01\right)$, de contingência social com parceiros do sexo oposto $\left(\mathrm{F}_{1,35}=5,973\right.$, p<0,05) e com colegas do mesmo sexo $\left(\mathrm{F}_{1,35}=\right.$ $12,832 \mathrm{p}<0,001)$, de faz-de-conta com pares do mesmo sexo $\left(\mathrm{F}_{1,35}=6,056, \mathrm{p}<0,05\right)$ e de regras com crianças de mesmo sexo $\left(\mathrm{F}_{1,35}=23,034, \mathrm{p}<0,001\right)$. As crianças de São Paulo suplantaram as de Ubatuba em brincadeiras de contingência física e social mistas e de faz-de-conta em grupos de crianças de mesmo sexo e as ubatubanas suplantaram as primeiras em jogos de regras em grupos de mesmo sexo. Foi constatado efeito de gênero sobre brincadeiras de contingência social $\left(\mathrm{F}_{1,35}=10,717, \mathrm{p}<0,01\right)$ e de faz-de-conta em grupos formados por crianças de mesmo sexo $\left(\mathrm{F}_{1,35}=5,565, \mathrm{p}<0,05\right)$. As meninas superaram os meninos em grupos de mesmo sexo em brincadeiras de faz-de-conta e de contingência social. (Tabela 7.3).

Tabela 7.3. Proporção média da participação em grupos de mesmo sexo e mistos em relação à participação total nos diversos tipos de brincadeira.

\begin{tabular}{|c|c|c|c|c|c|c|c|c|}
\hline & Meı & São P & aulo & inas & & Ubat & cuba & inas \\
\hline Tipo de brincadeira & Misto & $\begin{array}{c}\text { Mesmo } \\
\text { sexo }\end{array}$ & Misto & $\begin{array}{l}\text { Mesmo } \\
\text { sexo. }\end{array}$ & Misto & $\begin{array}{c}\text { Mesmo } \\
\text { sexo }\end{array}$ & Misto & $\begin{array}{c}\text { Mesmo } \\
\text { sexo }\end{array}$ \\
\hline Exercício físico & 0,34 & 0,36 & 0,36 & 0,43 & 0,26 & 0,18 & 0,21 & 0,59 \\
\hline Contingência física & 0,30 & 0,20 & 0,40 & 0,30 & 0,02 & 0,20 & 0 & 0 \\
\hline Contingência social & 0,50 & 0 & 0,41 & 0,19 & 0,11 & 0,22 & 0,13 & 0,77 \\
\hline Turbulenta & 0,43 & 0,17 & 0,25 & 0,25 & 0,24 & 0,31 & 0,24 & 0,36 \\
\hline Construção & 0,36 & 0,34 & 0,39 & 0,41 & 0,04 & 0,41 & 0,41 & 0,29 \\
\hline Faz-de-conta & 0,48 & 0,51 & 0,16 & 0,83 & 0,38 & 0,28 & 0,30 & 0,50 \\
\hline Regras & 0,20 & 0,20 & 0,22 & 0,07 & 0,05 & 0,72 & 0,21 & 0,68 \\
\hline
\end{tabular}


Para se verificar em que tipos de brincadeiras foram mais comuns os grupos de mesmo sexo e mistos, calcularam-se testes $t$ pareados entre proporções de grupos mistos e de mesmo sexo em relação ao total de cada tipo de brincadeira, separadamente para meninos e meninas de São Paulo e de Ubatuba. Os resultados destes testes que apresentaram significância estatística, inclusive marginal, estão transcritos na Tabela 7.4.

Tabela 7.4. Comparações dois a dois dos diversos tipos de brincadeira em grupos mistos e de um só sexo conforme origem e gênero.

\begin{tabular}{llcc}
\hline \multicolumn{1}{c}{ Grupo } & \multicolumn{1}{c}{ Brincadeiras } & $\mathrm{t}$ & $\mathrm{p}$ \\
\hline Meninos SP & Conting. social mista $>$ mesmo sexo & $t_{9}=2,676$ & $<0,05$ \\
Meninas SP & Faz-de-conta mesmo sexo $>$ mista & $t_{9}=4,115$ & $<0,01$ \\
Meninos Ubatuba & Regras mesmo sexo $>$ mista & $t_{8}=2,162$ & $<0,10$ \\
& Construção mesmo sexo $>$ mista & $t_{8}=1,915$ & $<0,10$ \\
& Cont. social mesmo sexo $>$ mista & $t_{9}=3,616$ & $<0,01$ \\
& Reninas Ubatuba mesmo sexo $>$ mista & $t_{9}=2,150$ & $<0,10$ \\
\hline
\end{tabular}

Conforme se constata pela Tabela 7.4, houve variação entre os grupos culturais e gêneros quanto à composição do grupo em função do tipo de brincadeira. Entre os meninos paulistanos, a única brincadeira em que houve diferença significativa entre composição mista e grupos de mesmo sexo foi a de contingência social, favorecendo a composição de grupos de ambos os sexos. Houve nítido predomínio de brincadeiras do mesmo sexo de faz-de-conta entre as meninas paulistanas, de construção (com significância estatística marginal) entre meninos ubatubanos, de regras entre meninos e meninas de Ubatuba (nessas, com significância estatística marginal) e de contingência social entre as últimas. Entretanto, além desses resultados, é interessante comentar algumas tendências reveladas nos dados da Tabela 7.3. Meninos de São Paulo tenderam a participar mais de brincadeiras de contingência social turbulentas e não turbulentas em grupos mistos, enquanto os de Ubatuba tenderam a participar de grupos de mesmo sexo em brincadeiras de contingência física, em jogos de regras e de construção e de grupos mistos apenas nas brincadeiras de faz-de-conta. 
Levando em conta que as brincadeiras de contingência social envolvem maior proximidade física e reciprocidade interacional entre as crianças, pode-se supor que os meninos paulistanos se permitiram mais dirigir essas aproximações a meninas, embora saibamos que, no grupo paulistano, tenham dominado as brincadeiras de contingência social do tipo distal. Com efeito, algumas das CSs mistas tinham um caráter erótico, como abraçar a parceira ou roçar-se nela. Enquanto essas abordagens sexuais revelaram certa sutileza entre os paulistanos, o único episódio com conotação nitidamente sexual entre um menino e uma menina de Ubatuba foi uma brincadeira turbulenta de simulação de coito, fato que indica o caráter mais rústico e direto de expressão dos meninos ubatubanos. Nos jogos de regras, eles raramente se compunham com meninas, o que é explicável no caso do futebol, dada a diferença de interesses, perícia e força física.

Mais difícil de explicar foi a maior participação de meninos ubatubanos em jogos de construção em grupos quase exclusivamente masculinos. Como tais brincadeiras se deram principalmente na areia, seu principal desafio, na época, era construir estradas e cavar buracos, tarefas muito provavelmente relacionadas com as de seus pais. Entretanto, a concentração desse tipo de brincadeira pode dever-se em parte ao acaso, já que as meninas foram observadas participando de grupos mistos em tarefas de fazer montes, cavar e modelar areia.

No que diz respeito às meninas, o fato mais notório foi a maior frequiência de brincadeiras de contingência social em grupos femininos. Especialmente entre as meninas de Ubatuba, grupo em que tais brincadeiras envolviam muito contato corporal, esse dado se explica pela já comentada maior intimidade nas relações femininas. Entre as paulistanas, digno de nota foi o fato de a maioria das brincadeiras simbólicas ocorrerem em grupos exclusivamente femininos. Esse achado está associado aos temas de brincadeiras observadas nas meninas de São Paulo, com atividades de cuidados com os "filhos", passeios a shoppings, cabeleireiros e atividades domésticas. Observe-se que, enquanto os meninos de São Paulo tenderam a apresentar menor estereotipia de gênero, as meninas paulistanas, em contraponto com as ubatubanas, tenderam a manifestar brincadeiras simbólicas prototipicamente femininas. 


\subsubsection{Tipos de brincadeira e modalidades de interação}

Para procurar estabelecer em que grau diversas variáveis independentes podem predizer uma variável dependente, utiliza-se o método de análise múltipla de regressão linear. Esse método permite avaliar em que medida os escores obtidos em diversas variáveis independentes estão associados àqueles obtidos na variável dependente, ou seja, em que medida as variáveis independentes são preditivas da dependente. Para apurar quais os tipos de brincadeira preditivos de atividade interativa e não interativa, procedemos a análises múltiplas de regressão linear pelo método stepwise para os dois gêneros dos dois grupos culturais, tomando como variável dependente a modalidade de interação (brincadeira interativa/ não interativa) e como variáveis independentes os tipos de brincadeira conforme o caráter predominante da ação (exercício físico, contingência física e social, BT, construção, faz-de-conta e regras). As modalidades de interação encontradas nas brincadeiras associativas e cooperativas/competitivas foram agrupadas como formas interativas de brincar e as verificadas nas brincadeiras solitárias e paralelas foram agrupadas como atividade lúdica não interativa. Uma síntese dos resultados obtidos encontra-se na Tabela 7.5.

Tabela 7.5. Tipos de brincadeiras preditivas de modalidades de interação.

\begin{tabular}{llll}
\hline $\begin{array}{l}\text { Modalidades } \\
\text { interação }\end{array}$ & Brincadeiras preditivas & $\begin{array}{l}\text { Gênero/ } \\
\text { origem }\end{array}$ & \multicolumn{1}{c}{$F$} \\
\hline Interativa & BT (positivamente) & Meninos SP & $\mathrm{F}_{1,8}=7,636^{*}$ \\
& Regra, BT (positivamente) & Meninos & $\mathrm{F}_{2,6}$ \\
& Conting. social (positivamente), & Ubat. & $10,495^{* *}$ \\
& $\begin{array}{l}\text { Meninas } \\
\text { (negativamente) }\end{array}$ & $\begin{array}{l}\mathrm{F}_{3,6} \\
\text { (nbat. }\end{array}$ & $26,374 * *$ \\
Não & Construção (positivamente) & Meninos SP & $\mathrm{F}_{1,8}=8,180^{*}$ \\
& Cont. física (positivamente) & Meninos & $\mathrm{F}_{1,7}$ \\
& Contingência social & Ubat. & $19,241^{* *}$ \\
& (negativamente) & Meninas & $\mathrm{F}_{1,8}=9,822^{*}$ \\
& Ubat. & \\
\hline
\end{tabular}

$* \mathrm{p}<0,05 ; * * \mathrm{p}<0,01 ; * * * \mathrm{p}<0,001$

A variável preditiva de brincadeira interativa entre os meninos de São Paulo foi BT, com associação positiva (Interativa $=0,419+0,955 \mathrm{BT}$ ). As variáveis preditivas de brincadeiras 
interativas entre os meninos ubatubanos foram jogos de regra e BT, ambas contribuindo positivamente (Interativa $=0,124+0,785$ Regra $+1,286 \mathrm{BT})$ e, entre as meninas ubatubanas, contingência social, contingência física e exercício físico, a primeira contribuindo positivamente e as duas últimas, negativamente (Interativa $=0,703+0,785$ Contingência Social $-5,293$ Contingência Física - 0,55 Exercício Físico). As brincadeiras preditivas do modo não interativo foram, para os meninos de São Paulo, construção, com relação positiva (Não interativa = 0,126 + 1,314 Construção), para os meninos de Ubatuba, contingência física, também positivamente associada (Não interativa $=0,119+1,96$ Contingência Física) e para as meninas ubatubanas, contingência social, com associação negativa (Não interativa $=0,244-0,574$ Contingência Social). Entre as meninas de São Paulo não se encontraram brincadeiras preditivas dos diferentes modos de interação.

Em outras palavras, dados qualitativos nos permitem afirmar que, entre os meninos ubatubanos, as brincadeiras de contingência física relacionaram-se com atividades solitárias e, entre os paulistanos, os jogos de construção associaram-se ao modo de interação paralelo, em que as crianças brincam lado a lado, mas sem interação ligada à atividade lúdica. Entre os meninos de São Paulo e de Ubatuba, brincadeiras turbulentas previram atividades interativas (Figura 7.17) e, entre esses últimos, os jogos de regra também se associaram positivamente ao modo interativo de brincar. A brincadeira de contingência social foi a principal modalidade lúdica a prever interação entre as meninas ubatubanas. Esse resultado era esperado tendo em vista o caráter essencialmente interativo das brincadeiras de contingência social. Entretanto, o achado não deixa de apontar mais uma vez para a importância das brincadeiras de contingência social, turbulentas ou não, para as interações sociais das crianças, sendo mais característica a modalidade turbulenta para o gênero masculino e a não turbulenta para o feminino.

\subsubsection{Participação nas diversas modalidades de brincadeira em relação ao}

\section{tamanho do grupo}

Procedemos a análises múltiplas de regressão linear pelo método stepwise, para os dois grupos e gêneros, com a finalidade de verificar os tipos de brincadeira preditivos dos diversos tamanhos de grupo, tomando como variáveis dependentes díades, tríades e políades e, como 
variáveis independentes, os tipos de brincadeira conforme o caráter predominante da ação. Uma síntese dos resultados obtidos encontra-se na Tabela 7.6.

Tabela 7.6. Brincadeiras preditivas dos diversos tamanhos de grupo, segundo gênero e origem

\begin{tabular}{llll}
\hline $\begin{array}{lll}\text { Tamanho de } \\
\text { grupo }\end{array}$ & Brincadeiras preditivas & Gênero/ origem & \\
\hline Díade & Conting. social proximal & Meninos SP & $\mathrm{F}_{1,8}=$ \\
Tríade & Conting. social distal & Meninos SP & $\mathrm{F}_{1,8}=$ \\
& BT proximal (negativamente) & Meninas & $\mathrm{F}_{1,8}=7,257 *$ \\
Políade & Conting. social distal & Meninas SP & $\mathrm{F}_{1,8}=6,744^{*}$ \\
\hline
\end{tabular}

Brincadeiras de contingência social proximal foram preditivas de interação lúdica em díades entre os meninos de São Paulo (Díade $=0,200+11,014$ CS proximal). Brincadeiras de CS distal previram negativamente brincadeiras em tríades entre os meninos paulistanos (Tríade $=0,235-3,129$ CS distal) e BTs proximais foram negativamente preditivas de tríades entre as meninas de Ubatuba (Tríade $=0,230-0,861$ BT proximal). Brincadeiras de CS distal previram positivamente políades para as meninas de São Paulo (Políade $=0,076+3,025$ CS distal). Não foram encontradas brincadeiras preditivas dos diversos tamanhos de grupo entre os meninos de Ubatuba.

Podemos, então, considerar que as demais brincadeiras, excluindo as de contingência social, não apresentaram relações com o tamanho do grupo. Os dados encontrados quanto à ocorrência em díades de brincadeiras de contingência social, turbulentas ou não, são coerentes com o caráter interacional dessas brincadeiras. Entretanto, a associação negativa de CS distal com tríades, ainda mais em se considerando sua relação positiva com políades, é mais difícil de explicar. Tais dados, contudo, não foram consistentes nos diversos grupos, devendo, portanto, ser ponderados com reservas. É mais provável que se expliquem ao levarmos em conta o conteúdo dessas brincadeiras nos diversos grupos: entre as meninas de São Paulo, por exemplo, 
foi comum a apresentação de habilidades de dança ou canto umas para as outras, o que justifica a associação de CSs distais com políades.

\subsubsection{Síntese}

Quanto à relação entre o tipo de brincadeira e as modalidades de interação, constatou-se que, entre os meninos de Ubatuba, as brincadeiras de contingência física associaram-se a atividades lúdicas não interativas e, entre os paulistanos, essas correlacionaram-se com os jogos de construção. Entre os meninos dos dois grupos culturais, brincadeiras turbulentas previram atividades interativas e, entre os ubatubanos, os jogos de regra também se associaram positivamente ao modo interativo de brincar. A brincadeira de contingência social foi a principal modalidade lúdica a prever atividade lúdica interativa entre as meninas de Ubatuba.

Verificou-se variação entre os grupos e gêneros em relação ao tipo de brincadeira facilitadora de participação conjunta de ambos os sexos. As brincadeiras turbulentas prevaleceram em grupos do mesmo sexo e as de faz-de-conta parecem ter favorecido a participação conjunta de ambos os sexos. Entre as crianças de Ubatuba, as brincadeiras de contingência social previram a formação de grupos de crianças de mesmo sexo.

Não se encontraram relações consistentes entre os diversos tamanhos de grupo e as modalidades de brincadeira.

\subsection{Considerações finais}

Praticamente todos os resultados relatados nesta sessão evidenciam que as questões de gênero estão intrinsecamente ligadas às de diversidade cultural, sendo, portanto, praticamente impossível dissociar-se a discussão da influência das duas variáveis sobre os grupos de brincadeira e sobre as brincadeiras em grupo. Mesmo em características mais gerais, como tamanho e composição do grupo, observaram-se claras diferenças entre os grupos culturais e gêneros. 
Tamanho e composição do grupo. Em relação ao tamanho do grupo de brincadeira, meninos de São Paulo e meninas de Ubatuba revelaram tendências semelhantes: tanto os primeiros quanto as segundas apresentaram maior freqüência de participação em políades do que seus pares de sexo oposto. A maior parte dos dados da literatura estão de acordo com os encontrados em São Paulo: meninos tendem a participar de grupos maiores e meninas preferem interações diádicas (Benenson et al., 2001; Hartup, 1983; Markovits et al., 2001). Foi o comportamento das crianças ubatubanas que divergiu do esperado. Por um lado, características como competitividade, relações hierárquicas definidas - normalmente atribuídas aos grupos masculinos - estiveram muito presentes nos grupos femininos de Ubatuba. Por outro lado, como comentamos em relação à freqüência de comportamento observador e de brincadeira não interativa, alguns meninos ubatubanos mostraram certa dificuldade de integração nas atividades grupais, o que, evidentemente, se refletiu nas médias encontradas. Provavelmente também definiram esse quadro, além das características de competitividade das meninas ubatubanas (manifestas, principalmente, através de uma certa implicância com os colegas), suas brincadeiras vivazes e movimentadas. Em contraste, o subgrupo de colegas do sexo masculino mais isolados - e, portanto, com baixo nível de interação grupal - apresentou tendência a manifestar um comportamento mais passivo.

Diversos autores, dentre eles Benenson et al. (2001) e Maccoby (1988), consideram que a inserção de meninos em grupos grandes esteja relacionada com a maior possibilidade de competitividade aberta que trazem as políades. Benenson et al. supõem que grupos maiores dispersem as fortes emoções causadas pela competição direta entre os indivíduos, propiciandolhes algum grau de anonimato e assegurando que a lealdade ao grupo tenha precedência sobre as relações individuais. Maccoby (1988) sugere que os homens podem aderir a comportamento competitivo mais aberto do que as mulheres, porque, em grandes grupos, o problema é "não ser passado para trás", enquanto, nas díades, a sensação é de "estar pisando em ovos". Em outras palavras, enquanto, em grupos grandes, as pessoas ficam menos expostas e as emoções são mais diluídas, a interação entre duas pessoas expõe mais ambas as partes, acarretando cuidados maiores em não ferir o outro, com o fim de preservar a relação. Essas argumentações ajudam a complementar a explicação da grande freqüência de políades entre as meninas ubatubanas, cujas interações foram bastante competitivas. A relação entre tamanho do grupo e conflitos será retomada no próximo capítulo, quando poderemos estabelecer relações mais específicas. 
Através das particularidades descritas, manifesta-se a configuração da microcultura do grupo de brincadeira. Confrontamo-nos, de um lado, com as diferenças individuais: conforme pondera Maccoby (1988), certamente, há meninas que preferem brincar em grupos grandes e há meninos que preferem brincar em duplas, assim como há meninas que gostam de brincadeiras movimentadas e não gostam de vestir bonecas, enquanto há meninos que preferem brincadeiras mais sossegadas. De outro lado, assistimos a configurações específicas de grupos com suas variadas redes e interconexões de relações. Diferenças individuais, combinadas com a diversidade de constituição dos grupos de companheiros e com peculiaridades macroculturais comporão um quadro que conferirá características particulares a cada grupo de brincadeira, o que indica claramente a importância da ampliação de pesquisas interculturais para a compreensão dos fenômenos implicados.

Os meninos participaram mais de grupos mistos do que as meninas. Esse resultado não era esperado, em vista dos dados relatados na literatura euro-americana, que indicam que, nesta faixa de idade, as crianças passam, em média, três vezes mais tempo brincando em grupos do mesmo sexo (Maccoby, 1988). Observações qualitativas permitem-nos levantar uma hipótese que poderia contribuir para explicar nossos dados. Constatamos que a maior parte dos meninos paulistanos mostrou maior adequação e diplomacia no trato social do que os ubatubanos, que apresentaram uma conduta mais rústica - fato que também pode ser comprovado por sua grande participação em brincadeiras turbulentas. As meninas ubatubanas, por sua vez, também se mostraram mais duras, dominadoras e rústicas do que as paulistanas. É possível, então, que, enquanto, em São Paulo, a conduta mais refinada de alguns meninos possa ter facilitado a interação com suas colegas do sexo feminino, em Ubatuba, o comportamento mais rústico e as brincadeiras mais agitadas das meninas tenham sido fatores que atraíram a aproximação de seus colegas. Em outras palavras, os dados parecem indicar menor estereotipia de gênero entre os meninos paulistanos e entre as meninas ubatubanas.

O estilo interacional mais rústico dos meninos praianos está, provavelmente, relacionado com o comportamento dos homens adultos das classes trabalhadoras, nas quais o papel masculino é mais definido e sua autoridade, menos questionada, conforme descreveu Nicolacida-Costa (1988), configurando-se um quadro em que não é tão necessário modular o próprio comportamento em função da reação do outro. Pela conduta arrojada das meninas ubatubanas, parece que as mulheres caiçaras desenvolveram, também, atitudes que facilitam a relação mais horizontal e equilibrada com o sexo oposto. 
No que diz respeito ao tamanho de grupos mistos, constatamos que díades e tríades mistas ocorreram mais freqüentemente nas crianças de São Paulo do que nas de Ubatuba, onde foram muito freqüentes os grupos grandes mistos. Supondo-se que o relacionamento em díades e tríades seja mais próximo, esses dados podem também indicar uma menor estereotipia de gênero (por parte do grupo masculino, já que a intimidade nas relações interpessoais é tida como atributo mais prototipicamente feminino) no grupo de São Paulo. Esse resultado pode ser parcialmente explicado por uma presumível menor estereotipia de gênero por parte de representantes da classe média da cidade de São Paulo. Encontraram dado semelhante Carvalho et al. (1993), que, comparando respostas de crianças de diferentes classes sociais de São Paulo e de Recife em relação ao que consideravam brincadeiras mais adequadas para um ou outro sexo, constataram que as crianças de classe alta de São Paulo apresentavam menor estereotipia de gênero do que as dos demais grupos.

Um aspecto levantado pela literatura em relação aos grupos compostos por ambos os sexos e que merece ser discutido, tendo em vista o comportamento das crianças observadas, é o da dominação de meninos sobre meninas em grupos mistos (Charlesworth \& LaFreniere, 1983). Embora não tenhamos obtido dados quantitativos a esse respeito, por não termos analisado a categoria de comportamentos indicativos de dominância, observações qualitativas permitem-nos dizer que tal não ocorreu no grupo de Ubatuba, onde as meninas se revelaram bastante dominadoras, o que talvez também ajude a explicar sua facilidade de inserção nos grupos de meninos, formando grupos mistos. Ocorreram alguns casos de dominação masculina no grupo de São Paulo, mas essa não foi a regra.

Outra hipótese que se levanta a respeito da preferência por brincar em grupos formados por companheiros de um só sexo ou por fazê-lo em agrupamentos de ambos os sexos diz respeito a características de feminilidade ou masculinidade das crianças. Teriam as meninas com características mais masculinas maior tendência a brincar com meninos e, por sua vez, os meninos com características mais femininas maior inclinação a brincar com meninas? Maccoby e Jacklin (1987) encontraram que meninas criadas de forma mais próxima àquela dos meninos, assim como eles, competiam mais e iniciavam mais agressões. Contudo, eram elas as que brincavam mais com outras meninas (e não com os meninos). As autoras concluem que brincar mais com crianças do mesmo sexo não é resultado de características mais femininas ou masculinas de personalidade. Nesse sentido, Maccoby (1988) pondera que um relacionamento provavelmente continuará com o tempo e será satisfatório para ambas as partes, se elas puderem 
influenciar uma à outra. Meninas, então, tenderiam a evitar situações em que não pudessem exercer controle sobre os meninos e procurariam estilos que funcionassem com eles. Aparentemente, as meninas ubatubanas - em parte devido a suas características mais ativas e dominadoras do que as de muitos meninos - foram mais bem sucedidas nessa tarefa do que as paulistanas.

Embora o enfoque do presente estudo não seja sobre diferenças individuais, é importante também considerá-las, pois existem variações em torno da preferência de crianças por companheiros (as) do mesmo sexo: algumas não mostram preferências relacionadas ao sexo, outras preferem brincar com pares do mesmo sexo e outras, com colegas do sexo oposto (LaFreniere et al., 1984).

O fato de, em Ubatuba, grupos mistos grandes terem sido mais freqüentes pode também indicar uma tendência à maior interação entre os gêneros quando a atividade escolhida requer muitos membros, não havendo, necessariamente, uma seleção de parceiros. Essa discussão nos remete à análise da composição do grupo em função dos tipos de brincadeira.

Tipos de brincadeira. No que tange à participação nas diversas modalidades de brincadeira, já evidenciamos que foram constatadas tanto semelhanças quanto diferenças entre meninos e meninas e entre os dois grupos culturais. As principais similaridades dizem respeito à estrutura das brincadeiras dos dois grupos, basicamente muito semelhantes, conforme se percebe pela Tabela 7.1. Ao analisar, porém, a freqüência das diversas atividades lúdicas, verificaram-se diferenças substanciais. Uma das mais evidentes diz respeito à ocorrência uniforme das diversas modalidades de brincar entre as crianças ubatubanas, em contraste com o predomínio de brincadeiras de faz-de-conta entre as paulistanas. Outras diferenças importantes foram a grande participação em jogos de regras das crianças ubatubanas, principalmente dos meninos, e em brincadeiras de contingência social turbulentas e não turbulentas por parte dessas mesmas crianças, quando comparadas às de São Paulo.

Esses dados reforçam as peculiaridades de cada microcultura de grupo de brincadeira e remetem-nos a considerar também diferenças culturais no estilo de criação. Examinando-se a alta incidência de brincadeira imaginativa nas crianças de São Paulo, destacamos, entre outras explicações plausíveis levantadas anteriormente, a possibilidade de que a cultura adulta em que se inserem enfatize o pensamento simbólico, enquanto a maior frequiência de brincadeiras de contingência social verificada nas crianças de Ubatuba pode estar relacionada com uma cultura 
que privilegia o valor da interação com o outro. $\mathrm{O}$ mesmo pode ser dito quanto ao caráter proximal/distal das brincadeiras de contingência: brincadeiras envolvendo contato corporal prevaleceram entre as crianças ubatubanas. Como levantamos no capítulo 2 deste trabalho, Keller (1998) diferencia entre contextos múltiplos, co-ativos de criação - em que há várias pessoas como parceiras interacionais - e diádicos - em que mãe (ou cuidadora) e criança ficam sozinhas a maior parte do tempo. Nos contextos diádicos, prevaleceria um modo distal de interação, voltado principalmente para a troca verbal, enquanto, nos co-ativos, o modo predominante de interação seria o contato corporal, que transmite calor emocional. $\mathrm{Na}$ fase de aquisição (dos três anos à entrada na puberdade), culturas ocidentais enfatizam o pensamento abstrato e lógico, enquanto as não-ocidentais destacam a observação, a atenção, a aprendizagem rápida, a boa memória, ao lado da destreza manual e de competências sociais éticas, como dever, responsabilidade, honestidade, respeito e obediência. O intenso contato proximal das crianças ubatubanas, assim como a menor freqüência de brincadeira simbólica, em benefício de atividades físicas e de contingência social, podem indicar que o estilo de criação da cultura ubatubana é mais próximo do não-ocidental, caracterizado, possivelmente, por um modo de criação mais semelhante ao de nosso ambiente de adaptação evolucionária. A alta freqüência dos jogos de regras entre os ubatubanos é também compatível com essa hipótese, tendo em vista, como já comentamos, sua alta incidência em crianças de grupos indígenas sul-americanos (Gosso et al., no prelo).

Retomando Nicolaci-da-Costa (1988), que considera dois modelos de socialização - o de identidade compartilhada e o de identidade diferenciada -, procuramos traçar paralelos desse paradigma com as duas microculturas dos grupos de brincadeira. O modelo de identidade compartilhada - que enfatiza a semelhança entre os membros de um determinado grupo social, reduzindo a necessidade de o indivíduo elaborar verbalmente suas experiências, intenções ou motivações pessoais - seria mais compatível com o estilo de brincar das crianças ubatubanas, que não priorizaram a brincadeira simbólica. Por sua vez, o modelo de identidade diferenciada que promoveria a atenção a processos internos, a diferenças individuais e enfatizaria o planejamento - aproxima-se mais do estilo de brincar das crianças paulistanas, que ocuparam grande parte de seu tempo brincando de faz-de-conta. Seguindo a mesma linha de raciocínio, deve-se observar que, possivelmente, as condições socioeconômico-culturais da comunidade ubatubana propiciariam o desenvolvimento da inteligência relativa a habilidades físicas, ao pensamento concreto e à busca de soluções imediatas para os problemas práticos, enquanto a 
cultura paulistana pesquisada estaria mais preocupada com o desenvolvimento do pensamento lógico-matemático, simbólico e conceitual.

As principais diferenças de gênero encontradas em relação ao tipo de brincadeira preferida - maior ocorrência de brincadeiras de contingência social entre as meninas e de contingência física entre os meninos - apontam na direção de uma microcultura de gênero em que a reciprocidade e o interesse pelas relações sociais é uma característica mais feminina e o efeito sobre os objetos, um definidor mais masculino. Maccoby (1988) também atribui grande parte da diversidade no comportamento de meninos e meninas a suas diferentes preferências em termos de brincadeira. Muito embora não tenhamos observado diferenças particularmente significativas no tempo dedicado aos diversos tipos de brincadeira em função do gênero - com exceção da participação em brincadeiras de contingência social, em que meninas superaram meninos e em BTs e brincadeiras de contingência física, em que os últimos superaram as primeiras -, constataram-se claras particularidades nos conteúdos das brincadeiras dos dois gêneros. Apesar de o tempo dedicado às brincadeiras de faz-de-conta dos meninos de São Paulo ter-se assemelhado ao das meninas, seus conteúdos foram bastante diferentes. Conquanto o tempo gasto em brincadeiras de exercício físico tenha sido semelhante em todos os grupos observados, os meninos de Ubatuba sobressaíram nos jogos de regras que envolviam ampla movimentação física e os de São Paulo, em longas corridas pelo pátio fazendo rolar pneus. Embora seja de grande consenso que os meninos prefiram atividades mais movimentadas e utilizem maior espaço físico em suas brincadeiras (Martin \& Fabes, 2001; Maccoby, 1988; Pellegrini \& Smith, 1998), em muito contribuiriam estudos específicos que discriminassem melhor o grau e tipo de movimentação física apresentado nas brincadeiras por ambos os gêneros.

A maior parte dos dados da literatura refere que meninas brincam mais de faz-de-conta do que meninos (Fein, 1981; P. K. Smith, 2002). Tal dado não se verificou entre as crianças de São Paulo, tendo sido observado apenas nas ubatubanas. Trata-se, provavelmente, de mais uma evidência de menor estereotipia de gênero por parte dos meninos paulistanos. Como concluíram Lansford e Parker (1999), em seu trabalho de observação de tríades em situação seminaturalística, não é possível supergeneralizar os estereótipos de gênero. Esses autores, além de constatarem grupos de meninos que agiam de forma intempestiva e enfatizavam a independência sobre a ação coletiva (38\%), observaram um subgrupo de tríades masculinas (43\%) cujo comportamento era semelhante ao de grupos femininos, pois seus membros tendiam a se aglutinar em torno de tarefas estruturadas e coordenadas, a trocar opiniões e a responder e 
dar atenção ao parceiro interacional. Apenas 59\% das tríades femininas mostraram-se capazes de uma ação organizada, com poucos sinais de exclusão, responsividade às solicitações das companheiras e discussões íntimas, incluindo questões de ações, sentimentos e opiniões de outros. Observou-se fenômeno semelhante no presente trabalho, em que, além de constatarmos subgrupos de meninos que se constituíam em torno de tarefas mais estruturadas, percebemos, também, no caso das meninas de Ubatuba, grupos de meninas com um comportamento prototipicamente masculino. Como afirma Maccoby (1988), é possível que a segregação de gênero seja mais um fenômeno de grupo do que um reflexo das preferências individuais de cada criança.

Como bem levantam Lansford e Parker (1999), deve-se questionar se os comportamentos observados nos dois grupos estudados representariam padrões locais e temporários de constituição grupal ou se seriam padrões duradouros de um particular conjunto de crianças ou de crianças em situações particulares. Evidentemente, essas questões poderão se mais bem respondidas se as observações forem estendidas por um período de tempo mais longo e realizadas com subgrupos das mesmas culturas em diferentes circunstâncias e com várias composições. Dito de outra forma, as diversas possibilidades contextuais de cada grupo de brincadeira necessitariam ser controladas para se extraírem conclusões mais generalizadas. Além de diversidades interculturais, deve-se considerar a grande variação existente entre creches e pré-escolas quanto aos recursos, ambiente físico e estilos pessoais dos educadores.

Ainda com relação aos tipos de brincadeira observados, esperávamos ter encontrado mais brincadeiras tradicionais entre as crianças de Ubatuba - brincadeiras de roda, de cabracega, de peteca, de pião, de bola de gude -, uma vez que elas convivem numa sociedade presumivelmente mais conservadora (Carvalho \& Pontes, 2003). Apesar de não o ser na intensidade que imaginávamos, observamos um número maior dessas brincadeiras nas crianças ubatubanas do que nas paulistanas. Destacaram-se, em Ubatuba, as brincadeiras de roda, de pega-pega, de esconde-esconde com o "pique" e jogos com corda: pular corda em grupo, passar por baixo e por cima da corda e "cabo-de-guerra" (Figura 7.18). A brincadeira de cabra-cega foi mais comumente observada em Ubatuba, embora tenha sido também registrada uma vez em São Paulo. Talvez, se fossem outras as condições de observação, nas ruas ou nos quintais das casas, por exemplo, pudéssemos ter constatado um número maior de brincadeiras tradicionais. Efetivamente, o que mais se destacou no grupo de Ubatuba foram as brincadeiras com o próprio corpo e com o do outro, como montar cavalinho, rolar sobre o corpo do outro, carregá-lo, 
rodopiar com ele - brincadeiras essas com um componente de intensa atividade física, mas que foram incluídas na categoria de contingência social por denotarem claramente a presença da motivação por provocar respostas contingentes nos companheiros e por responderem contingentemente a eles.

Composição do grupo x tipo de brincadeira. Verificou-se variação entre os dois grupos culturais e gêneros em relação ao tipo de brincadeira facilitadora da participação conjunta de ambos os sexos. As brincadeiras turbulentas prevaleceram em grupos do mesmo sexo e as de faz-de-conta foram as que mais congregaram crianças de ambos os sexos. Entre as crianças de Ubatuba, as brincadeiras de contingência social foram preditivas da formação de grupos de crianças de mesmo sexo. Como já discutimos, é possível que as interações mais próximas e íntimas que ocorrem nas brincadeiras de contingência social sejam mais bem aceitas entre crianças do mesmo sexo, enquanto o caráter mais distal das brincadeiras de faz-de-conta facilite a aproximação entre meninos e meninas.

Deve-se ressaltar, contudo, além da menor participação em grupos mistos por parte dos meninos de Ubatuba, quando comparados aos paulistanos, a maior segregação sexual do ubatubanos em brincadeiras de construção e de regras. Particularmente nos jogos de regras, em que predominaram o futebol e o tênis de praia, a preferência dos meninos de Ubatuba foi por interagir com companheiros do mesmo sexo. Souza e Rodrigues (2002), estudando crianças de oito e nove anos, apontam a importância que adquirem diferentes estilos de brincadeira para a segregação sexual, como variáveis situacionais. Conforme salientam Markovits et al. (2001), grupos de mesmo sexo podem ser explicados mais pela atração por iguais do que pela rejeição a crianças do sexo oposto.

Já que, segundo Maccoby (1988), procedimentos que visam a diminuir a segregação sexual através da intervenção de adultos têm efeito temporário - o que em parte fundamenta as afirmações de Harris sobre a influência preponderante dos companheiros sobre o comportamento das crianças -, nossos dados demonstram a importância de se levar em conta o tipo de brincadeira espontânea para a diminuição da segregação e facilitação da integração sexual. Destaque especial deve ser dado para a participação dos meninos dos dois grupos culturais em brincadeiras de faz-de-conta. Essas, quando ocorrem na forma de atividade coletiva, favorecem a simbolização conjunta, a transformação de elementos reais e ideacionais, o conhecimento do outro, a comunicação e a negociação entre pares, a divisão e 
complementação de papéis e o treino de papéis sociais - funções que se revelam tão importantes para o desenvolvimento infantil.

Modalidades de interação $x$ tipo de brincadeira. Quanto à relação entre o tipo de brincadeira e as modalidades de interação, constatou-se que, entre os meninos de Ubatuba, as brincadeiras de contingência física associaram-se positivamente a atividades lúdicas solitárias e, entre os paulistanos, os jogos de construção relacionaram-se com o modo não interativo de brincar. Entre os meninos dos dois grupos culturais, brincadeiras turbulentas foram preditivas de atividades interativas e, entre os ubatubanos, os jogos de regras também se associaram positivamente ao modo interativo de brincar. A brincadeira de contingência social foi a principal modalidade lúdica a prever interação entre as meninas de Ubatuba. Percebe-se, também por esses dados, que não houve uniformidade nas tendências interacionais conforme a modalidade de brincadeira nos dois grupos culturais, grande parte motivada pelos diferentes tipos de brincadeiras a que mais se dedicaram paulistanos e ubatubanos. Contudo, percebe-se, entre os meninos dos dois grupos culturais, tendências mais claras da opção que fizeram quando as dificuldades de interação impediam sua penetração em atividades interativas: brincar com objetos, seja solitária, seja paralelamente. O que aproximou os dois grupos culturais e gêneros no tipo de interação em atividades lúdicas foram as brincadeiras de contingência social, intrinsecamente relacionais. Destacou-se, também, entre os meninos ubatubanos a participação interativa em jogos de regras, já comentada.

Para a compreensão de todas as particularidades e semelhanças dos grupos de brincadeira, além do entendimento da espécie humana como sociobiologicamente cultural (Bussab \& Ribeiro, 1998), é particularmente atraente e útil a proposta de Corsaro e Molinari (1990), que enunciaram o conceito de "cultura de companheiros" (peer culture). Os autores definem essa cultura como o conjunto de atividades, artefatos, valores e interesses compartilhados pelo grupo de companheiros de idade, tanto aqueles provenientes do mundo adulto, quanto os originados e transformados dentro do próprio grupo infantil. Assim sendo, cada criança vai incorporando, em seu ritmo de crescimento biologicamente determinado, o que vivencia no dia-a dia.

A criatividade, como uma faculdade essencialmente humana, encarrega-se de trazer inovações ao grupo de companheiros. Por sua vez, essas inovações tornam-se práticas mais ou menos consolidadas num dado período de tempo, mediante o interesse que provocam nos pares. Às práticas mais ou menos consagradas dos grupos de brincadeira incorporam-se novas, dada a 
grande flexibilidade e adaptabilidade do ser humano. Essas, por sua vez, transformam-se continuamente num movimento que vai configurando as relações estabelecidas no grupo de pares, ao mesmo tempo em que novas capacidades vão sendo acrescentadas à criança, em função do próprio amadurecimento de características físicas, cognitivas e socioafetivas. A dinâmica que se estabelece entre o desenvolvimento, de um lado, e as inovações, aprendizagens e influências macroculturais, de outro, constitui microculturas de grupos de brincadeira muito particulares, que merecem ser pesquisadas nos diversos grupos sociais, sob o risco de, não o fazendo, incorrermos em generalizações precipitadas e errôneas. 


\section{RELATANDO OS EPISÓDIOS DE ZOMBARIA E OS CONFLITOS}

\subsection{Provocações e zombaria}

Iniciamos este capítulo pela análise das provocações e da zombaria, pois a mensagem dúbia dos comportamentos classificados sob esse rótulo, que envolvem, ao mesmo tempo, sinalizadores (explícitos ou implícitos) de brincadeira e de hostilidade leva-nos a inseri-los entre a brincadeira e o conflito.

\subsubsection{Segundo grupo cultural e gênero}

A ANOVA calculada para testar efeitos de origem e de gênero sobre o total de provocações em relação ao tempo de observação não revelou diferenças significativas entre os dois grupos culturais e gêneros. Entretanto, pela Figura 8.1, observa-se que a média de comportamentos de zombaria apresentada pelos meninos de Ubatuba é, praticamente, o dobro daquela verificada entre as crianças de São Paulo e quase o quádruplo da média de provocações mostradas pelas meninas ubatubanas.Tais diferenças não foram suficientes para revelar um efeito estatisticamente significativo, provavelmente pelo número pequeno de incidentes de zombaria e por eles estarem concentrados em poucas crianças. Em São Paulo, 60 \% das crianças apresentaram esse tipo de comportamento, enquanto somente $26 \%$ das crianças ubatubanas zombaram dos colegas. A criança que revelou maior concentração de incidentes de provocação foi um menino ubatubano, que exibiu 15 comportamentos desse tipo. 


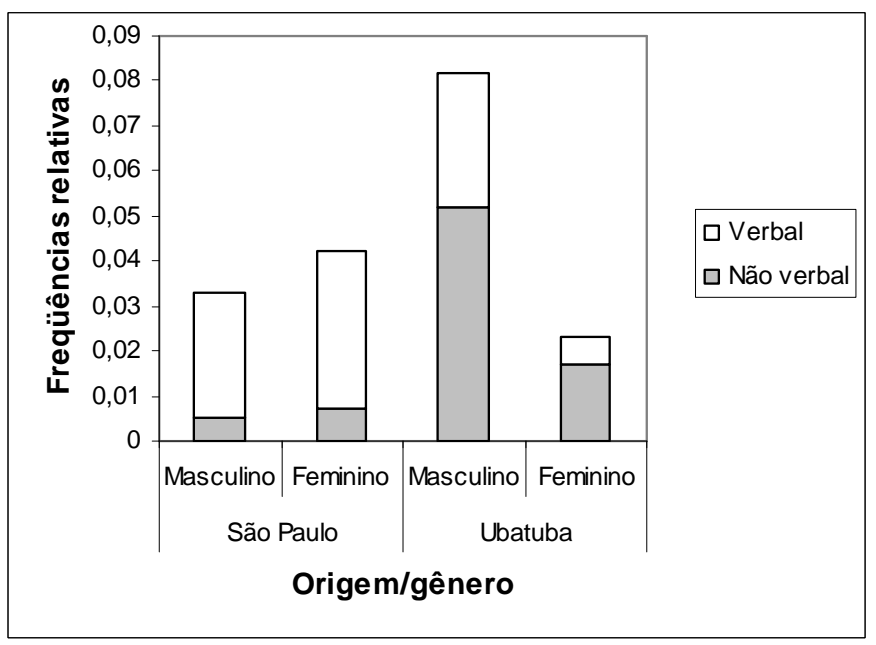

Figura 8.1. Freqüências relativas ao tempo das duas formas de zombaria - verbal e não verbal -, segundo grupo cultural e gênero.

Embora a MANOVA 2 × 2 calculada para testar o efeito de origem e de gênero sobre comportamentos de zombaria não verbal e verbal (índices relativizados em razão do tempo de observação) tenha revelado efeito significativo de origem (Lambda de Wilks $=0,763, \mathrm{~F}$ $2,34=5,287, \mathrm{p}<0,01)$, testes univariados subseqüentes revelaram apenas diferenças marginalmente significativas de origem quanto à zombaria não verbal, tendo as crianças de Ubatuba superado as de São Paulo neste aspecto. Pela Figura 8.1, observa-se que esse resultado se deve, em grande parte, ao comportamento dos meninos ubatubanos.

Comparando-se os dois grupos culturais, observa-se a mesma tendência já comentada em relação à participação em brincadeiras de contingência social: preponderaram as provocações do tipo proximal, com contato corporal entre as crianças de Ubatuba e, embora de forma estatisticamente não significativa, predominaram as provocações distais e verbais entre as crianças paulistanas. Entendendo-se a zombaria como um comportamento que envolve um componente de brincadeira e tendo em vista os dados já relatados no presente trabalho em relação às brincadeiras de contingência social e aqueles encontrados por Lee-Manoel et al. (2003) - que verificaram maior número de toques sociais entre as crianças ubatubanas -, era de se esperar que a zombaria em forma de contato proximal prevalecesse em Ubatuba.

É importante retomar os relatos de Bonta (1997) e de Keltner et al. (2001), que descrevem o uso de zombaria como prática educativa em sociedades indígenas e que atestam que essa é uma prática que necessita ser culturalmente contextualizada. Para obtermos mais elementos para a compreensão de como a zombaria se insere nas diferentes culturas dos grupos estudados, seria, obviamente, necessário investigar como esse comportamento se 
processa nos intercâmbios sociais entre adultos e entre esses e as crianças nas duas comunidades.

Resultados mais expressivos não foram encontrados, provavelmente, como já afirmamos, pela pequena freqüência e grande variação interindividual na exibição do comportamento de zombaria, concentrada em poucas crianças dos dois grupos. Shapiro et al. (1991) também observaram grandes diferenças individuais no "teasing", que corresponde ao que chamamos de zombaria. Ilustramos a seguir episódios em que se observa que zombar faz parte do estilo interacional de Ig e de Yn (dois meninos de Ubatuba).

Ig diz: Começou a briga! Tu, tu, tu .. A polícia!

Yn (com "cara de deboche") - A polícia rebola.

Ig repete, rebolando: A polícia rebola!

Ig dá a mão a Ga, dizendo: Me prende!

Ig diz a Ga: Vamos por aqui, meu amor! Vem aqui, mano!

Yn (caçoando): Rebola, rebola.

Ya se aproxima.

Ig (dirigindo-se a Ya e rebolando): Rebola, rebola..

Ig senta-se ao lado de And. Levanta-se, dizendo: rebola, rebola pra quebrar.

Esse pequeno episódio ilustra os limites entre brincadeiras de contingência social verbal, não verbal e provocação. O observador, apenas com o relato verbal, não pode discriminar exatamente o que ocorre e precisa se basear em pistas não verbais para classificar o comportamento como provocativo. A malícia de Yn é evidente pela "cara de deboche", expressão entre o riso e o escárnio, que nos faz inferir uma intenção de provocar alguma reação no(s) outro(s). Ig adere à proposta de uma forma mais lúdica, sem a mesma intenção aparente de Yn, levando a situação a um desfecho de brincadeira. O exemplo a seguir, envolvendo os mesmos meninos, tem algo também de brincadeira de contingência social, mas é mais claramente provocativo no final.

Ig está parado com a mão no tronco de uma árvore.

Yn chega e dá um tapa no seu braço. Ig o segue, mas logo desiste. Corre pelo pátio de areia e empurra Yn. Abaixa as calças e mostra a cueca. Conversa com Yn lado a lado.

Ig abaixa totalmente as calças. Yn ri. Ig levanta as calças, rindo. Sobe numa pequena árvore, perto de onde estão alguns colegas

Afasta-se temporariamente do grupo. Vai até a outra ponta do pátio e volta. Abaixa as calças novamente. Abaixa as calças sacode o corpo e ri, aparentemente provocando alguém. Ya faz o mesmo (Figura 8.2). 
Transcrevemos, abaixo, exemplos de crianças de São Paulo que se envolveram em provocações. O primeiro episódio revela um misto de BT e de provocação, porém com final mais perturbador para o menino Leo, diferentemente do que ocorreu nos exemplos acima; já o segundo, aparentemente, não revela conseqüências negativas imediatas para nenhuma das crianças envolvidas.

1) Gu S e Vi sentam-se em cima de Leo.

Com cara de raiva, Leo grita: Sai daí!

Leo sai. Gu S e Ro o perseguem

Ni bate nas nádegas de outra criança que passa.

Vi faz o mesmo em Leo, que faz cara de triste.

2) Vi Ra e Vi Fe passam e Tho diz: Popozuda!

Ni repete.Tho e Ni repetem o coro três vezes, sem produzir reação aparente nas colegas.

Ni joga para o alto o morcego de brinquedo que tem na mão e mostra seu feito para ViRa.

Os exemplos citados ilustram que pode haver diferentes reações por parte do alvo da zombaria, comentadas a seguir.

\subsubsection{Reações à zombaria}

Pelos episódios descritos, observamos que há diferentes graus de hostilidade e de brincadeira nas provocações, bem como diversas reações a elas, dependendo do contexto e das crianças envolvidas. Para verificar como a zombaria era interpretada pelos colegas, computamos os comportamentos que se seguiram à provocação. $\mathrm{Na}$ figura 8.3, encontram-se as frequiências absolutas de cada tipo de evento seqüencial, nos dois grupos culturais e gêneros. Constata-se que, quando comparada às demais categorias, a conseqüência vira brincadeira foi a mais freqüente, seguida de agride. O caráter ambíguo da zombaria assim se confirma. 


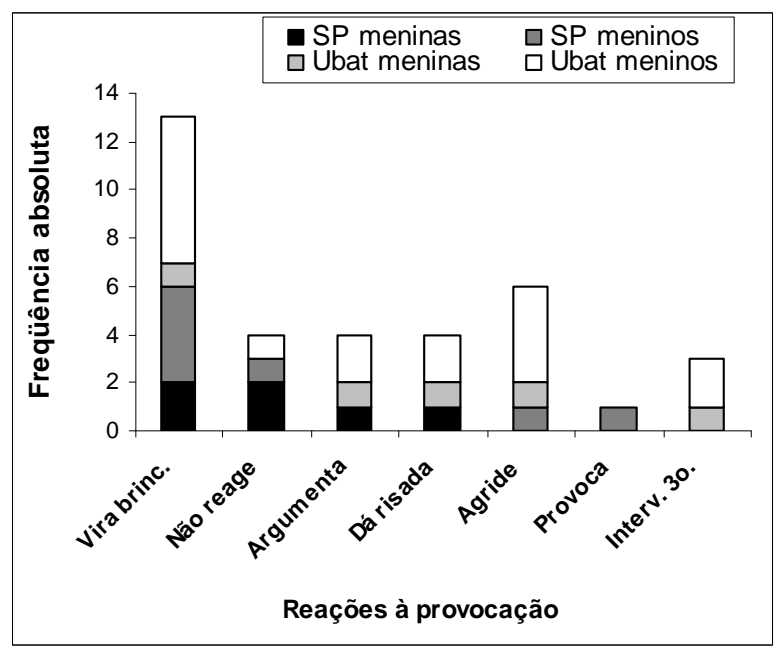

Figura 8.3. Reações à zombaria segundo origem e gênero.

Se compusermos três agrupamentos - um de reações positivas (vira brincadeira, argumenta, dá risada), outro de respostas negativas (agride, provoca) e um terceiro de reações neutras, ou mais difíceis de serem enquadradas numa ou noutra categoria (não reage, há intervenção de terceira parte) -, constatamos que as respostas positivas superaram as demais. Esses dados nos permitem concluir que, nestes grupos, as provocações foram predominantemente interpretadas como convites para a brincadeira, embora possam, também, ter sido entendidas como ato hostil. ser entendidas como ato hostil.

Embora tenhamos encontrado poucos episódios de zombaria entre as crianças estudadas, pelas reações variadas às provocações, é possível que estejam em jogo pistas contextuais que não analisamos, como também variáveis individuais, como temperamento, desenvolvimento de habilidades sociais e cognitivas. Assim como são pouco freqüentes os incidentes de zombaria nesta idade, também faltam na literatura elementos para compararmos nossos dados.

Keltner et al. (2001), relatando estudos com adultos que mostram maior incidência de provocações em situações que potencialmente gerariam conflito, consideram que a zombaria pode ocorrer em resposta a conflitos em potencial, permitindo que os indivíduos negociem os problemas virtualmente, antes que surjam. A zombaria é um comportamento social que revela um alto grau de complexidade e de nuances e, talvez também por essa razão, pouco freqüente na idade das crianças estudadas e pouco pesquisado. O "teasing" mereceria maior atenção dos estudiosos do desenvolvimento, desde seu surgimento na criança - que coincide 
com os primeiros atos simbólicos que denotam a percepção de sentimentos dos outros (Dunn \& Slomkowsky,1992) - até a idade adulta. Os elementos envolvidos na motivação das provocações, as reações, desfechos e consequiências desse comportamento tão peculiar carecem, sem dúvida, de um tratamento especial que foge ao escopo do presente trabalho, dada sua perspectiva de fornecer um panorama geral de como funcionam os grupos de brincadeira e como transcorrem os conflitos em duas culturas. Tendo em vista o caráter essencialmente interacional da zombaria, que visa a provocar reações nos parceiros interacionais, a complexidade de elementos cognitivos nela envolvidos e sua importante função na regulação social, reafirmamos a inegável contribuição para a compreensão do desenvolvimento das interações e das relações sociais que trariam estudos dedicados exclusivamente ao tema.

\subsection{Conflitos}

Adotando um termo empregado por Shantz (1987), descreveremos inicialmente a "anatomia" dos conflitos nos dois grupos culturais e gêneros. Pelos dados apresentados até agora, podemos prever que certos elementos dos conflitos sejam expressos de forma diversa entre as crianças paulistanas e ubatubanas e entre meninos e meninas, embora grandes semelhanças entre os comportamentos dos subgrupos também sejam esperadas.

\subsubsection{Freqüência de conflitos, segundo grupo cultural e gênero}

A ANOVA calculada para testar o efeito de origem e de gênero sobre o número de conflitos, relativizados pelo tempo de observação, não revelou diferenças significativas. Verificou-se, entretanto, conforme representado na Figura 8.4, ligeira diferença nas médias observadas: os meninos de Ubatuba revelaram menor número de conflitos do que os garotos de São Paulo e do que as meninas dos dois grupos; as meninas dos dois grupos culturais apresentaram igual freqüência de conflitos. Acreditamos que a menor incidência de conflitos nos meninos de Ubatuba possa ter sido compensada pela maior freqüência de zombaria apresentada 
por eles, o que indicaria, segundo constataram Keltner et al. (2001), que a zombaria pode ter um efeito na prevenção de conflitos.

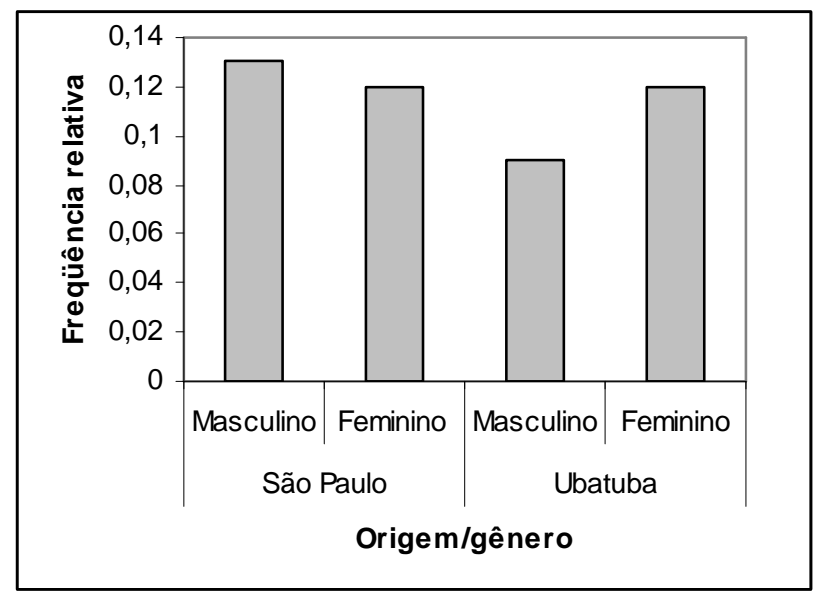

Figura 8.4. Freqüência relativa dos conflitos conforme origem e gênero.

Apesar das pequenas diferenças encontradas, consideraremos que os dois grupos e gêneros apresentaram aproximadamente o mesmo número de conflitos. Tendo em vista as funções do conflito na regulação social, podemos supor que os dois grupos a exerçam igualmente e que possíveis diferenças devam estabelecer-se na análise mais detalhada das modalidades de conflito.

Esse resultado não se coaduna com a maioria dos dados encontrados na literatura internacional. Laursen e Hartup (1989), Miller, Danaher e Forbes (1986) e Shantz (1986), por exemplo, encontraram maior número de conflitos entre meninos do que entre meninas. Estudos mais recentes, porém, como os de Hawley (2002) e de Murphy e Eisenberg (1996, 2002), tendem a relativizar as particularidades de gênero, evidenciando que aspectos que difeririam entre meninos e meninas estariam mais relacionados a estratégias que ocorrem durante os conflitos e a seus objetivos do que a sua freqüência. Supomos que, como se verificou em relação a diversas características da brincadeira, as variações entre as crianças inseridas em diferentes contextos são grandes também em relação aos conflitos.

Miller et al. (1986) atribuem as diferenças de gênero relativas ao número de conflitos ao tipo de atividades escolhidas por meninos e por meninas: as atividades escolhidas por meninos, mais movimentadas e menos organizadas, dariam maior margem a desentendimentos. Pelas 
características mais solitárias do comportamento de alguns meninos ubatubanos e mais ativas de suas colegas, constatamos, no grupo de Ubatuba, o inverso do que se verifica nos estudos de crianças euro-americanas: embora de forma estatisticamente não significativa, as meninas conflitaram mais do que seus colegas do sexo masculino. Entre as crianças paulistanas, contudo, eventuais diferenças podem dizer mais respeito à "anatomia", ou seja, à forma como se configuraram os conflitos do que à sua freqüência.

Quanto ao número de conflitos constatados, Shantz (1987) relata estudos com crianças de 18 a 62 meses, que encontraram oito conflitos por hora em média, variando esse número de quatro a dezessete. Essa freqüência é compatível com nossos dados. Como diferentes autores têm concepções diversas de conflitos - bastando para alguns a oposição e, sendo necessária, para outros, a insistência após a oposição -, esse número pode variar de um estudo para outro. Dentro de um conceito mais liberal, como o proposto por Garvey (1984) e empregado neste trabalho, em que bastam duas unidades para definir um conflito (oposição e reação a ela), esse número é evidentemente maior do que aquele encontrado em estudos que usam ao menos três unidades ou elos para definir um conflito. Comparações mais confiáveis não são possíveis, uma vez que a maioria dos pesquisadores não relata o número de unidades encontradas, por não ter estudado os conflitos sob esse prisma.

\subsubsection{Número de elos}

A ANOVA calculada para testar o efeito de origem e de gênero sobre a proporção entre número de elos e número de conflitos revelou efeito estatisticamente significativo de gênero $\left(F_{1,35}=3,998, p=0,05\right)$, marginalmente significativo de origem $\left(F_{1,35}=2,660, p<0,10\right)$ e de interação entre ambos os fatores $\left(\mathrm{F}_{1,35}=2,712\right.$, $\left.\mathrm{p}<0,10\right)$. Pela Figura 8.5, constata-se que essa diferença ocorreu devido ao maior número de elos apresentados pelas meninas de São Paulo. 


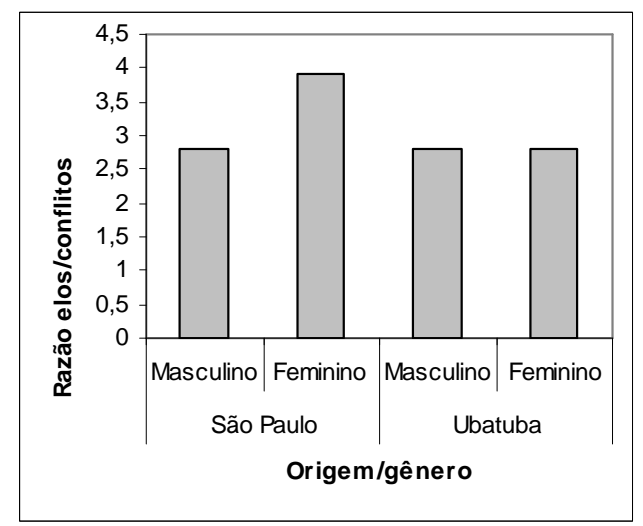

Figura 8.5. Razão elos/conflitos segundo origem e gênero.

A constatação de uma maior proporção de elos por conflito por parte das meninas de São Paulo evidencia que, durante as disputas, elas apresentaram maior número de trocas, envolvendo predominantemente verbalizações, conforme veremos adiante. Esse dado está de acordo com os resultados da maior parte dos estudos sobre diferenças sexuais em conflitos, que destacam maior negociação por parte das meninas e mais soluções impostas e unilaterais por parte dos meninos (Hawley, 2002; Murphy \& Eisenberg, 2002).

De maneira geral, pode-se dizer que os conflitos observados foram breves. Laursen e Hartup (1989) concluem que conflitos de dois elos diferem dos demais, pois são de baixa intensidade e ocorrem entre crianças que já estavam interagindo. Shantz (1987) encontrou que, entre crianças de 18 e 62 meses, os conflitos eram curtos (durando, em média, 24 seg). Não efetuamos medida de tempo, mas podemos comparar o número de elos ou unidades dos conflitos encontrados em nosso estudo com os resultados de Shantz, que relata que $92 \%$ dos conflitos observados tiveram menos do que dez elos e $66 \%$, menos do que cinco. Constatamos que os conflitos mais longos tiveram, no máximo, dez elos, sendo que $50 \%$ deles se compuseram de três unidades ou menos. A disparidade entre os dados pode ser explicada pela diferença de métodos empregados nos dois estudos. Como partimos de observação naturalística com registro in loco, é possível que tenhamos perdido detalhes nos registros em relação àqueles obtidos através de gravação filmada em recinto fechado.

A perspectiva trazida por Murphy e Eisenberg (2002), quando tratam das emoções relacionadas a conflitos, é bastante explicativa no que diz respeito a variações na duração dos conflitos. As autoras relatam que uma variável importante na continuação do conflito é o tipo de 
emoção despertada: de raiva ou de tristeza. Reações de tristeza motivariam um corte mais abrupto do conflito, enquanto as de raiva poderiam levar a uma escalada da disputa, gerando, portanto, episódios mais longos. Não usamos neste estudo nenhuma medida das emoções, mas é possível que expressões fisionômicas de desapontamento estivessem relacionadas com desistências mais rápidas e episódios mais curtos. É essa, portanto, uma interessante perspectiva a ser explorada em estudos futuros.

\subsubsection{Elementos dos conflitos}

Passamos a analisar semelhanças e diferenças nos aspectos constitutivos dos conflitos: motivos, estratégias de oposição, respostas à oposição e desenlaces. Para os testes estatísticos, utilizamos índices que indicassem a proporcionalidade dos dados. Desta forma, dividiu-se, para cada sujeito focal, a incidência dos diversos tipos de motivos pelo total de motivos, das diversas estratégias de oposição pelo total de oposições, das modalidades de reação à oposição pelo total de táticas de reação e das formas de desenlace pelo total de desfechos.

\subsubsection{Motivos}

A Figura 8.6 mostra a distribuição dos diversos motivos de conflitos por grupo cultural e gênero. Observa-se, em todos os grupos, predominância da disputa por objetos. Em seguida, para as meninas dos dois grupos aparece disputa pela vez, espaço ou lugar na fila e, em terceiro lugar, disputa por autoridade ou controle social. Entre os meninos ubatubanos, após disputas por objeto, aparecem ameaça ou agressão física aparentemente injustificadas e disputas por controle social. Entre os meninos de São Paulo, há uma distribuição relativamente uniforme dos motivos não predominantes. 

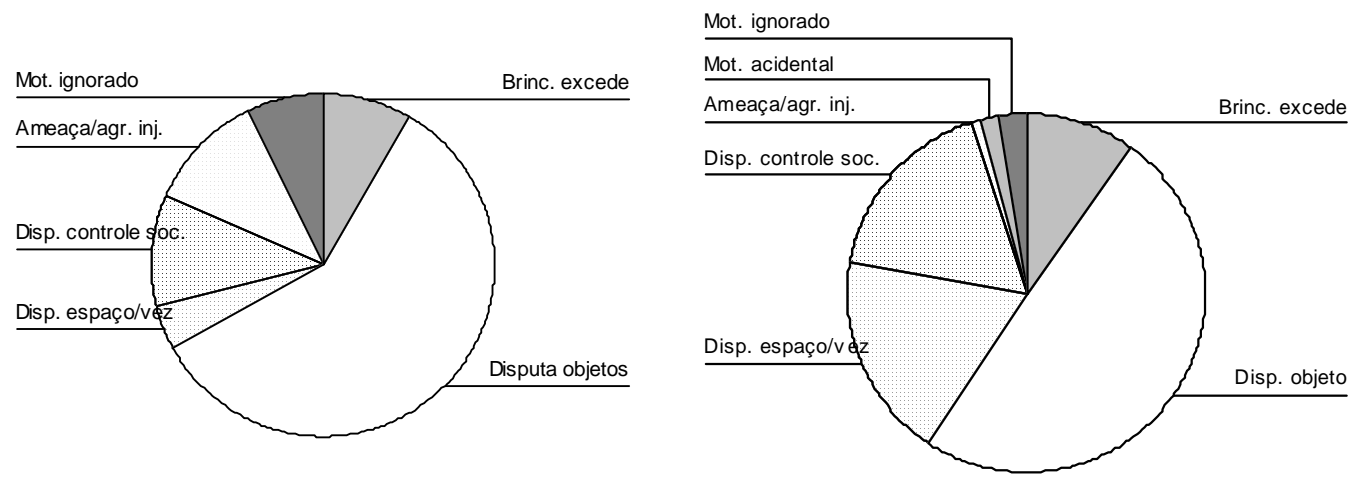

Meninos Ubatuba

Meninas Ubatuba
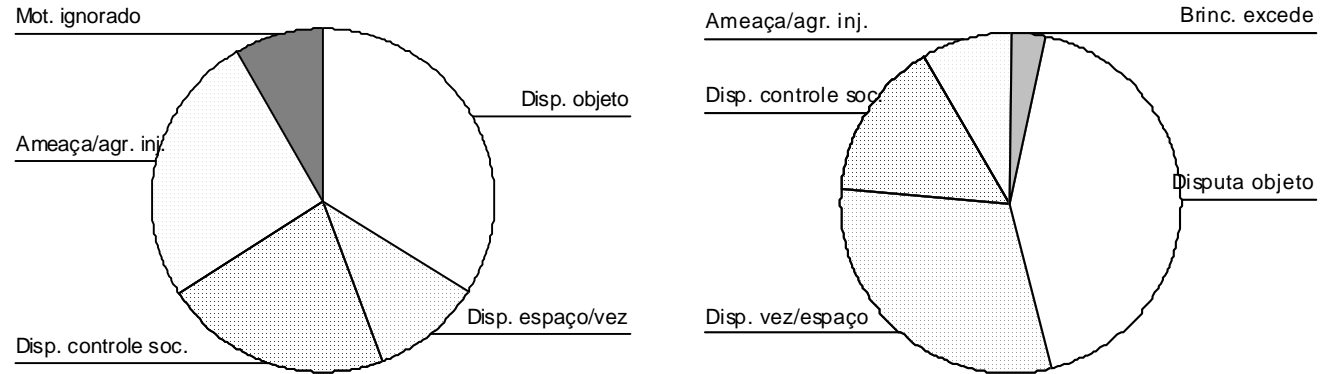

Figura 8.6. Distribuição dos motivos nos dois grupos culturais e gêneros.

A MANOVA 2 × 2 calculada para testar efeito de origem e de gênero sobre as diversas modalidades de motivo de conflito revelou apenas efeito marginalmente significativo de gênero (Lambda de Wilks $=0,701, \mathrm{~F}_{6,30}=2,131, \mathrm{p}=0,79$ ). Análises univariadas subseqüentes revelaram efeito de gênero sobre: disputa de espaço, vez ou lugar na fila $\left(F_{1,35}=6,860, p<0,05\right)$, com as meninas excedendo os meninos neste aspecto; ameaça e agressão aparentemente injustificadas $\left(F_{1,35}=4,427, p<0,05\right)$ e motivos ignorados $\left(F_{1,35}=3,224, p<0,10\right)$, aspectos em que meninos superaram as meninas. Embora o motivo tivesse sido considerado ignorado quando não havia, no período de observação, antecedentes que justificassem o conflito, é possível supor-se que, assim como os conflitos aparentemente injustificados, as disputas desencadeadas por motivos ignorados tenham sido causadas por situações não imediatamente anteriores às observadas. Rose \& Archer (1999) ressaltam a importância da vingança, normalmente ignorada 
em outros estudos, como objetivo de conflitos. Evidentemente, na maioria dos casos, com a metodologia que empregamos, é difícil depreender quando houve vingança.

A grande incidência de conflitos por disputas de objetos reflete provavelmente o nível de desenvolvimento das crianças estudadas, indicando a importância da posse de brinquedos e de outros objetos para elas. Shantz (1987) relata estudos que encontraram que, em crianças de três a cinco anos de idade, a mais freqüente causa de disputas era por objetos. Laursen e Hartup (1989) verificaram que, com o aumento da idade, decrescia a freqüência de disputas por objetos.

$\mathrm{Na}$ suposição de que as crianças ubatubanas vivam numa sociedade em que a interdependência é mais valorizada, e, portanto, em que partilhar objetos seria uma atitude cultivada, poder-se ia esperar que a disputa por objetos fosse menor nesse grupo. Gosso (comunicação pessoal), por exemplo, encontrou que a partilha de bens é uma atitude comum e respeitada entre as crianças Parakanã. Greenfield et al. (2003) encontraram que, entre imigrantes mexicanos nos Estados Unidos, partilhar tinha prioridade maior do que entre famílias angloamericanas, as quais colocavam a divisão de bens e de objetos como uma opção pessoal e não como dever social. Contudo, embora tenha sido ligeiramente menor a disputa por brinquedos entre os ubatubanos, a diferença não é expressiva, indicando que as crianças ubatubanas já estão imbuídas de valores compatíveis com uma sociedade mais individualista na concepção de Greenfield et al.

Murphy e Eisenberg (1996) verificaram que conflitos de meninas referiam-se mais à interação social, enquanto os de meninos diziam respeito à disputa por objetos. Não foi o que observamos em nossos grupos: os meninos de São Paulo apresentaram freqüência ligeiramente maior de disputa por objetos do que suas colegas, mas, em Ubatuba, o inverso ocorreu: meninas revelaram um pouco mais de disputas por objetos do que os meninos. Entretanto, meninas dos dois grupos revelaram mais conflitos pela vez na brincadeira, por espaço e por lugar na fila. Caso esse motivo de disputa indique maior preocupação com a relação - o que não é muito provável -, então, poder-se-ia dizer que as meninas dos grupos observados apresentaram tendência a mostrar maior preocupação com o relacionamento com os companheiros do que os meninos. Acreditamos, contudo, que esse tipo de disputa entre as meninas esteja mais relacionada com algumas atividades a que se dedicaram. As ubatubanas freqüentemente faziam filas para subir em árvores, ocasião em que entravam em grandes disputas e enganações para conseguirem passar à frente dos colegas e, portanto, levar vantagem, galgando os primeiros lugares da fila, conforme exemplo que se segue. 
Ta (menina) põe a mão em todos os colegas da fila e diz: pego, pego, pego!

Passa na frente dos colegas e empurra Wa, que está subindo na árvore. Chega sua vez de subir; fica olhando para cima, aparentemente aguardando que Wa pule. Acontece um empurra-empurra na fila. Quando Wa está prestes a pular, Ta sobe.

Fica parada no tronco com as pernas em volta da árvore. Demora para subir, escorrega e pula. Enquanto os colegas se empurram na fila, aproveita para subir de novo.

Voltando para o chão, agarra Fe por trás; esse se livra e começa a subir na árvore. Ta volta para a fila e empurra Wa. Os dois passam a brincar de rolar no chão.

Algumas meninas de São Paulo comportavam-se de maneira semelhante no escorregador, no trepa-trepa e no gira-gira:

Pa sobe com La a escada de corda do trepa-trepa.

$P a-V a i$, menina doida!

La desce e se afasta

Mga chacoalha-se na escada de corda.

Pa chacoalha Mga na escada.

Enfrentam-se, discutem.

Pa não quer deixar Mga subir.

Pa olha para Mga com cara de raiva.

Pa (com ar de desaforada): Você não vai descer agora, é? Você vai descer e eu vou subir.

Discutem. Enfrentam-se com o olhar.

Shantz (1987) relata trabalhos que mostram que tentativas de entrar nas brincadeiras com conseqüente resistência dos colegas é a segunda causa mais freqüente de conflitos. Nosso método não contemplou essa categoria, mas, nos exemplos acima, podemos ver situações em que disputas por objetos e por vez ou lugar podem implicar tentativas frustradas de entrar na brincadeira, categoria que também teria alta freqüência, caso tivéssemos utilizado o critério de separá-la das demais.

Os meninos superaram as meninas em conflitos por motivo ignorado e por ameaças ou agressões aparentemente injustificadas. Embora a categoria motivo ignorado pudesse ser 
decorrente de limitações do método - que, em alguns casos, só permitiu o registro de uma parte dos conflitos -, sua maior freqüência, ao lado das ameaças e agressões aparentemente sem motivo, pode indicar fenômeno de significado semelhante. A literatura está repleta de estudos que demonstram que meninos usam mais agressividade em conflitos do que as meninas (Chung \& Asher, 1996; Miller et al., 1986; Otta \& Souza, 1999; Rose \& Archer, 1999; Shantz, 1986). Com efeito, esse fenômeno é bastante claro entre as crianças ubatubanas, embora, proporcionalmente, também os meninos de São Paulo tenham apresentado mais agressões aparentemente injustificadas do que suas colegas.

É também interessante lembrar que, por dados de literatura que acentuam a importância da hierarquia em grupos de meninos (Harris,1998), poder-se-ia esperar que eles apresentassem mais disputas por controle e por dominação social do que as meninas. Tal fato não se verificou nos grupos estudados, o que pode indicar que essa tendência não é tão generalizada conforme se pensava ou que está se tornando menos típica como característica de gênero nos tempos atuais ou, ainda, - hipótese que é mais provável - que as meninas também tenham passado a se preocupar mais com o controle social. Os exemplos que se seguem podem ilustrar essa tendência nos dois sexos.

1) Ni (menino), batendo os braços como asas, vocaliza: Vuuum ...

Ni diz a Vi (menina): Você ia na guerra dos Digimons.

Vi-Me deixa em paz!

Da-Eu virei menino de novo.

Ni e Da correm atrás de Vi.

Ni diz a Vi-Você era Digimon.

$V i-E u$ odeio ser Digimon.

$\mathrm{Ni}$ - Eu era Digimon. O Da era homem.

Ni fala grosso e ameaça Vi. Vai até a estrutura de sustentação das balanças e faz

um gesto como se a quebrasse.

$V i$ - Aqui era a casa da bruxa.

$\mathrm{Ni}-\mathrm{Não}$, eu que mando.

2) Re (menina) tenta pegar algo na bolsa de Vi Fe (menina).

Vi Fe reage: Não!

Re desiste e diz: Todo mundo dormindo!

Vi chama os colegas para comerem.

Todos saem do colchonete e Re se irrita: Todo mundo silêncio!

Re diz: Todo mundo silêncio, senão eu não vou mais brincar.

Silêncio, já tou ficando nervosa, minha garganta já tá doendo e não tem graça. Se não, eu não vou mais brincar, nem a Yo. 
3) Yo (menina) diz a Da (menino): Vamos brincar, eu sou a mãe você o filhinho.

Da - Não. Eu sou a mãe e você a filha.

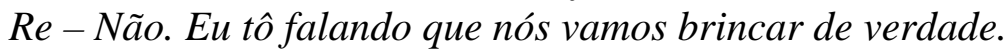

Ca e Re (meninas) se afastam.

Yo diz para Ca: Ah! Brinca vai...

Da - Não, essa é a mãe e essa é a filha. (duas bonecas).

\subsubsection{Estratégias de oposição}

Para verificar a distribuição das diversas estratégias de oposição, dividiu-se cada uma das estratégias adotadas pela criança focal pelo total de estratégias de oposição empregadas por ela. Agrupando-se as proporções de estratégias afiliativas num bloco e coercitivas em outro, obtêmse os dados apresentados na Figura 8.7. A MANOVA calculada para testar efeito de origem e de gênero sobre os dois tipos de estratégia não revelou resultados estatisticamente significativos. Esse dado mostra que, nos grupos estudados, não se constatou uma tendência marcante de as meninas empregarem mais estratégias afiliativas do que os meninos - como se evidencia em muitos trabalhos (Chung \& Asher, 1996; Hartup et al., 1993; Miller et al., 1986; Rose \& Archer, 1999) -, embora, no grupo de São Paulo, quando comparadas com os garotos, as meninas tenham revelado dados nessa direção.

Fato digno de nota foi a predominância de estratégias coercitivas sobre as afiliativas em todos os grupos. Esse resultado revela que, entre as crianças, a maioria dos conflitos não se instalou através do diálogo e sim de medidas unilaterais. Com efeito, Shantz (1987) relata que as soluções bilaterais surgem a partir dos oito anos de idade. A autora argumenta que, dos três aos sete anos de idade, conflitos são resolvidos unilateralmente, interrompendo a interação ou através de força física. Trata-se de soluções do aqui e agora. Talvez esse critério de bilateralidade empregado por Shantz seja muito rígido e estrito, pois, entre nossas crianças, já aparecem preocupações com os sentimentos do parceiro. Nossos dados são mais compatíveis com o ponto de vista de Hawley (2002), que sugere que táticas coercitivas e pró-sociais estão altamente relacionadas, em crianças de três a seis anos, na efetividade de controle de recursos. Segundo a autora - ao contrário do que se poderia esperar de crianças mais velhas, de adolescentes e de adultos -, em pré-escolares, não haveria necessariamente oposição entre táticas afiliativas e coercitivas: ambas se confundem e se misturam na maior parte das vezes e na maioria das crianças. 


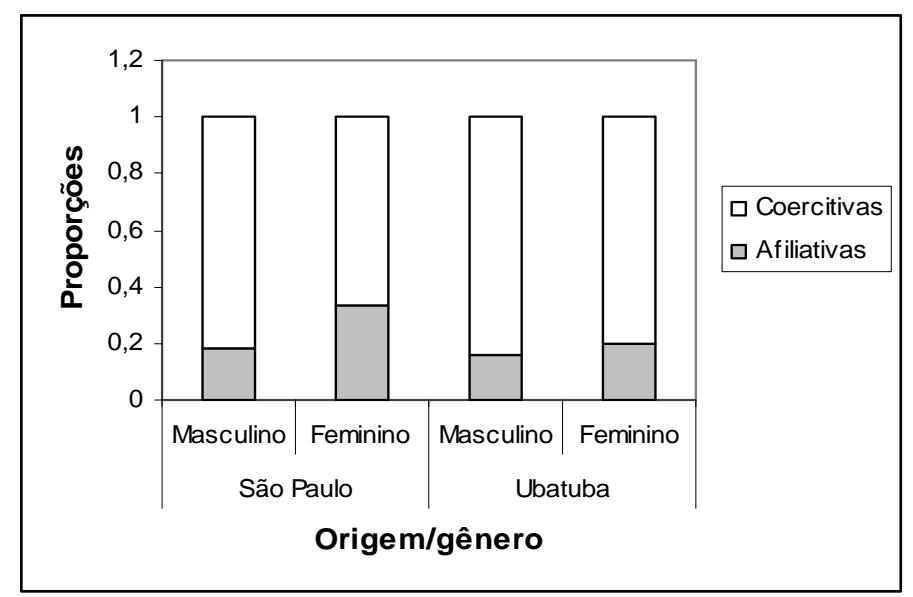

Figura 8.7. Proporções de estratégias de oposição coercitivas e afiliativas por grupo cultural e gênero.

Verificando-se as estratégias de oposição em separado, obtém-se a distribuição apresentada na Figura 8.8. Observa-se, entre as crianças ubatubanas, quando comparadas às de São Paulo, uma diversidade menor de estratégias adotadas. As táticas mais comumente empregadas pelas crianças de Ubatuba e pelos meninos de São Paulo foram agredir fisicamente e tirar objetos. Entre as meninas paulistanas, encontra-se a negativa simples como estratégia tão comum quanto agredir e tirar objetos e, sobretudo entre elas, verifica-se maior diversidade de estratégias de oposição.

A MANOVA 2 x 2 calculada para testar efeitos de origem e de gênero sobre as diversas estratégias de oposição revelou efeito significativo de origem sobre essas categorias (Lambda de Wilks $\left.=0,557 ; \mathrm{F}_{8,28}=2,788, \mathrm{p}<0,05\right)$. Análises univariadas subseqüentes mostraram efeito marginalmente significativo de origem sobre as categorias agredir verbalmente ou zombar $\left(\mathrm{F}_{1,35}\right.$ $=3,675, \mathrm{p}<0,10)$, ameaçar retirar a amizade $\left(\mathrm{F}_{1,35}=3,871, \mathrm{p}<0,10\right)$ e fazer imposições verbais $\left(\mathrm{F}_{1,35}=3,871, \mathrm{p}<0,10\right)$. Em todos esses comportamentos, as crianças de São Paulo superaram as de Ubatuba, mesmo porque, entre essas últimas, não se registraram ocorrências dessas categorias. 

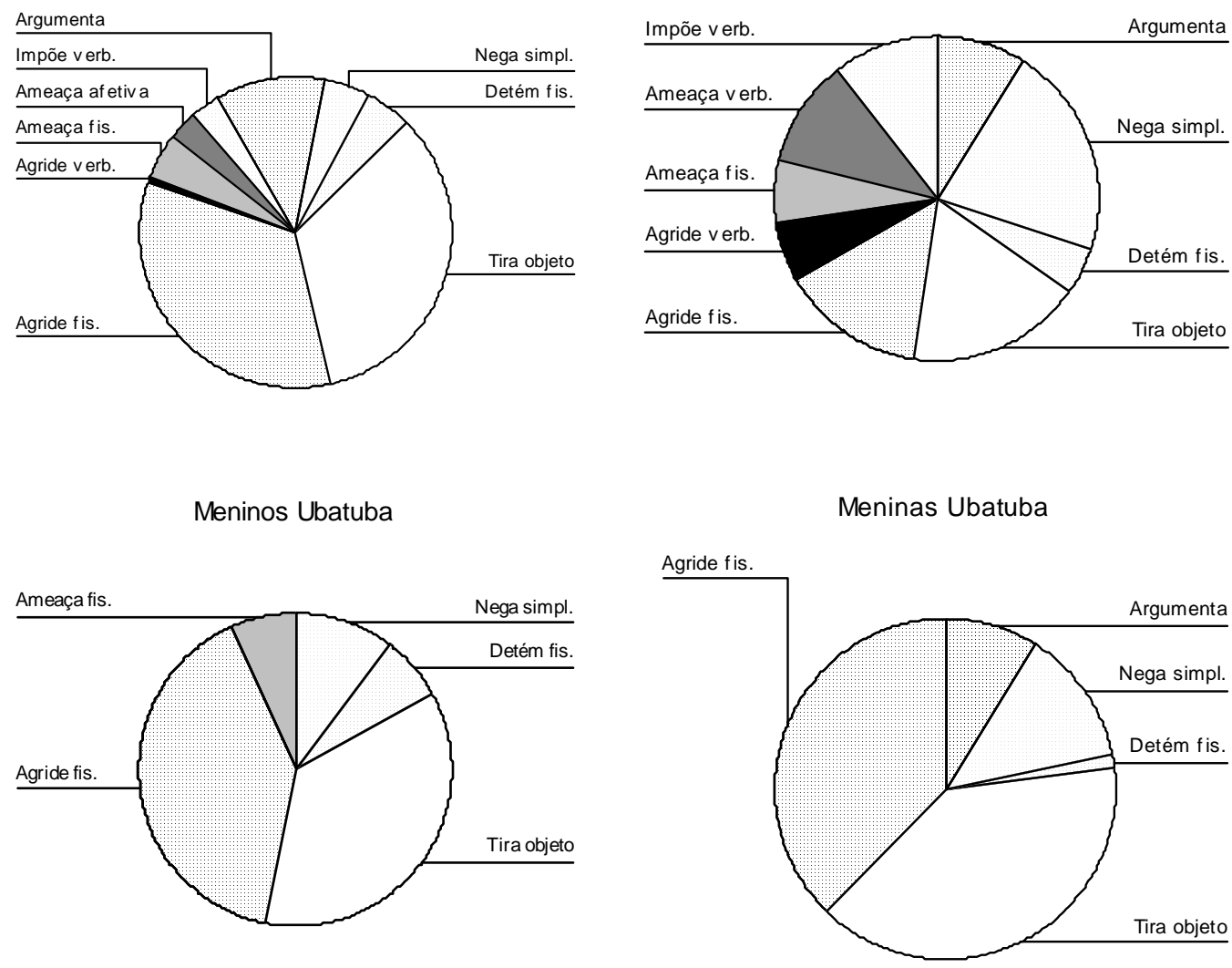

Figura 8.8. Estratégias de oposição por grupo cultural e gênero.

Embora fosse esperado, mediante comparação com dados da literatura, que os meninos excedessem as meninas na utilização de agressão física como estratégia de oposição (Laursen \& Hartup, 1989; Sánchez-Martin et al., 2000), não foram constatadas diferenças estatisticamente significativas nesse aspecto. Entretanto, se analisarmos apenas o grupo de São Paulo, essa expectativa se confirma: meninos excederam suas colegas em táticas agressivas $\left(t_{18}=2,794\right.$, p $<0,05$ - Figuras 8.8 e 8.9). Esse é mais um dado que revela o comportamento menos prototipicamente feminino das meninas de Ubatuba, cuja frequiência de comportamentos fisicamente agressivos foi equivalente à de seus colegas do sexo masculino.

Murphy e Eisenberg (1996) verificaram, em crianças mais novas (pré-escolares), que a agressão física era relativamente rara (ocorrendo entre $5 \%$ e $20 \%$ em episódios de conflito), predominando, entre elas, estratégias verbais de oposição. As autoras constataram um índice $14 \%$ de agressão física em episódios de conflito entre crianças de sete e 13 anos de idade. Shantz (1987) verificou que, em crianças de cinco anos e meio, a maior parte dos conflitos 
não envolvia agressão: 49\% das oposições eram arrazoados sobre a divergência e 32\%, negativas simples. Os subgrupos aqui estudados, com exceção das meninas de São Paulo, exibiram um nível maior de agressão do que relatam as autoras. Com efeito, em todos os grupos, a argumentação foi bastante rara e, combinada com a negativa simples, chega a pouco mais de $25 \%$ das estratégias apenas entre as meninas de São Paulo, subgrupo em que o índice indicativo de negativa simples e de argumentação foi mais alto.

A distribuição de estratégias de oposição reafirma a tendência das crianças de Ubatuba de utilizarem mais táticas envolvendo contato proximal (agredir fisicamente, tirar o objeto) do que as de São Paulo e essas, mais táticas verbais (impor, agredir verbalmente e ameaçar retirar a amizade) do que as primeiras. É notória a semelhança de frequiência de uso de estratégias físicas entre meninas e meninos ubatubanos como reação à provocação de conflitos. Também na freqüência de tirar objetos as reações das meninas de Ubatuba assemelham-se às apresentadas pelos meninos.

As estratégias utilizadas pelo grupo de São Paulo estão mais de acordo com os dados obtidos em trabalhos com crianças euro-americanas: meninas usariam mais táticas verbais e meninos, mais expedientes físicos diretos (Murphy \& Eisenberg, 1996; Rose \& Archer,1999). É importante lembrar que certos aspectos que, embora ligados à cultura, não são inerentes a ela, também podem estar influenciando as estratégias mais diretas e agressivas das crianças ubatubanas. É, por exemplo, amplamente reconhecida a influência exercida por situações de hostilidade vivenciadas em casa sobre o comportamento agressivo das crianças (Ballif-Spanvill, Clayton \& Hendrix, 2003). Soubemos que tal era o caso de um dos meninos mais agressivos do grupo de Ubatuba, cuja família, segundo relato da professora, utilizava expedientes de agressão física em casa, entre pais e filhos e entre irmãos. Evidentemente, as diferenças individuais e o ambiente familiar, embora não tenham sido abordadas neste trabalho, exercem grande influência na exibição e na administração de conflitos.

Conquanto se reconheça que comportamentos coercitivos (ameaçar, agredir) sejam tão eficientes quanto as estratégias pró-sociais na solução de conflitos (Hawley, 2002), há relatos de que as estratégias de oposição diferem entre as culturas. Fry (1988), como já apontamos, revelou que a agressão entre pares era muito mais proeminente entre crianças de uma comunidade Zapotec violenta do que em crianças de uma comunidade vizinha pacífica, sugerindo que existe uma ligação estreita entre padrões adultos específicos de relacionamento interpessoal e a administração de conflitos entre crianças. Embora não tenhamos pesquisado 
diretamente a agressão ou agressividade destas crianças e dos adultos de sua comunidade, evidências indiretas que denotam o comportamento mais rude dos meninos ubatubanos podem indicar que estejam seguindo modelos dos adultos de sua comunidade. Tal é o caso de afirmações como "homem não chora, quem chora é bicha", do uso abundante de palavras de baixo calão e de gestos grosseiros.

É também de se destacar a pequena variedade de estratégias de oposição apresentadas pelas crianças ubatubanas, quando comparadas com as de São Paulo. É possível que esse dado também esteja relacionado com as diferenças nos códigos de comunicação: crianças de São Paulo valer-se-iam de mais alternativas, em virtude da flexibilidade de código que têm que desenvolver, enquanto as de Ubatuba, cuja cultura é mais simples e estampada dentro de valores mais tradicionais, não teriam tanta necessidade de dominar recursos mais indiretos e sofisticados de ataque e de defesa.

\subsubsection{Respostas à oposição}

Para se compararem as respostas à oposição dos dois grupos culturais e gêneros, calculou-se, inicialmente, para cada criança, a razão entre os diversos tipos de reação à oposição e o total de repostas à oposição. Em seguida, foram agrupadas as respostas de tipo coercitivo, não coercitivo e evitativo. Procedeu-se, então, ao cálculo de uma MANOVA 2 × 2 para apurar efeitos de origem e de gênero sobre essas três modalidades de reação. Obteve-se apenas efeito marginalmente significativo de interação entre origem e gênero (Lambda de Wilks =0,876, $\left.\mathrm{F}_{2,34}=2,408, \mathrm{p}=0,10\right)$. Análises univariadas subseqüentes indicaram que este efeito ocorreu em relação às respostas não coercitivas $\left(\mathrm{F}_{1,35}=4,795, \mathrm{p}<0,05\right)$. Pela Figura 8.10, observa-se que as meninas de Ubatuba superaram os meninos e os garotos paulistanos excederam ligeiramente suas colegas neste tipo de reação. 


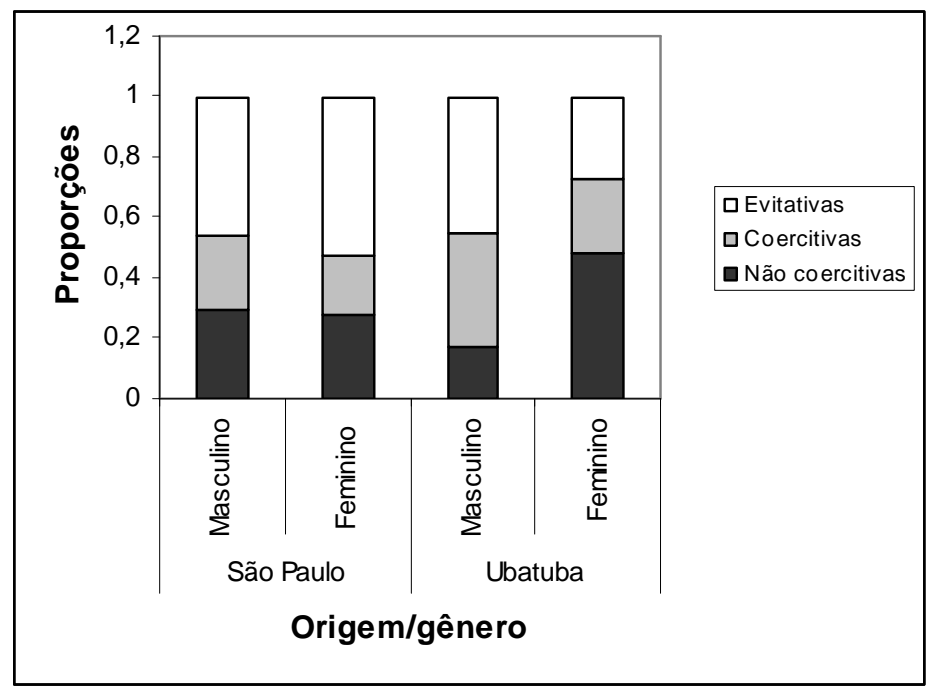

Figura 8.10. Proporções de respostas à oposição, segundo origem e gênero.

Embora de forma não significativa do ponto de vista estatístico, observa-se que os meninos ubatubanos superaram as meninas de seu grupo e as crianças de São Paulo no número de repostas coercitivas, revelando maior conformidade com pesquisas de diferenças de gênero do que os meninos de São Paulo, que, assim como suas colegas do sexo feminino, tiveram um ligeiro predomínio de respostas do tipo evitativo.

Se, nas estratégias de oposição, os meninos paulistanos mostraram maior agressividade física, nos padrões de reação à oposição, exibiram equilíbrio entre respostas coercitivas e não coercitivas, ultrapassando ligeiramente suas colegas nesse último tipo de reação, contrariando expectativas segundo as quais as meninas seriam mais negociadoras e os meninos, mais truculentos e impositivos em suas respostas (Hartup et al., 1993; Miller et al., 1986; Shantz, 1986). Já as crianças de Ubatuba aproximaram-se mais do esperado, tendo as meninas apresentado, em 50\% dos casos, formas mais afiliativas de responder à oposição. É interessante observar que, nesse aspecto, as garotas ubatubanas aproximaram-se mais do protótipo de reação feminina, contrariando outras tendências apresentadas anteriormente, como se houvesse uma “compensação" pelas formas mais truculentas de iniciar os conflitos e de mostrar oposição. É importante lembrar que muitos dos conflitos cessaram na reação à oposição - o que explicaria também a menor ocorrência de expedientes coercitivos nesse elo da cadeia, quando comparado com o das estratégias de oposição, tendo em vista que as crianças tenderam a apresentar desenlaces mais afiliativos, como veremos adiante. 
Aplicaram-se testes $\mathrm{t}$ pareados para verificar se havia diferenças estatisticamente significativas entre o emprego de táticas coercitivas, não coercitivas e evitativas, separadamente para meninos e meninas dos dois grupos culturais. Obtiveram-se resultados estatisticamente significativos $(\mathrm{p}<0,05)$ para as meninas de São Paulo, que apresentaram mais respostas evitativas do que coercitivas $\left(t_{9}=2,640\right)$, e para os meninos de Ubatuba, cujas reações coercitivas superaram as afiliativas $\left(\mathrm{t}_{8}=2,335\right)$, tendo sido essas superadas pelas evitativas $\left(\mathrm{t}_{8}=\right.$ $2,530)$.

As meninas paulistanas foram o agrupamento que apresentou maior número de respostas evitativas e os meninos ubatubanos revelaram predomínio de reações evitativas sobre as afiliativas. Murphy e Eisenberg (2002), referindo-se a duas emoções básicas durante o conflito raiva e tristeza - , argumentam que a raiva estaria ligada a situações em que é possível obter o alvo desejado e a tristeza, a situações em que a criança não acredita ser possível atingir seu objetivo. Segundo as autoras, quando a situação evoca tristeza, as reações durante o conflito estariam ligadas a passividade e a táticas evitativas. A raiva estaria ligada a objetivos não amigáveis e a tristeza, ao desejo de ser confortado, o que, em última instância, poderia levar também a objetivos afiliativos. Nessa perspectiva, é possível que a contra-reação das meninas paulistanas e dos meninos ubatubanos - que se manifestou mais na forma de evasão da situação - pudesse estar ligada a objetivos afiliativos.

Embora as expressões faciais não tenham sido analisadas quantitativamente neste estudo, observações qualitativas permitem-nos dizer que, confirmando as suposições das autoras, como mencionamos anteriormente, respostas evitativas pareceram mais associadas à emoção de tristeza., enquanto as coercitivas relacionaram-se mais com a emoção de raiva. Demonstrando algumas evidências que confirmam o ponto de vista de Murphy e Eisenberg (2002), transcrevemos abaixo alguns exemplos de aparente tristeza em respostas evitativas. Nos dois primeiros exemplos, a interação se dá entre meninos, no segundo, entre um menino (Ni) e uma menina (El). O quarto exemplo ilustra uma reação de raiva.

1) Um grupo joga bola. Mat entra no meio.

Le - Não, Mat (e bate na cabeça de Mat).

Mat afasta-se, com a aparência entristecida

2) Ig diz a Mar: Você não tá brincando, porque você não deu o rodo pra ele. Mar vai para perto de outro grupo. Pára e observa os colegas, sem jeito.

3) Ni diz a El: Larga isso... vou derrubar. 
Ni vira o balde que estava com El e chuta a areia.

El abaixa a cabeça e nada fala.

4) Ri diz: Eu que sou o motorista, já falei!

Guc para Ri: Solta o caminhão!

$R i-N \tilde{a} o !$

Professora - Vamos para fora?

$R i$ - Vou levar o caminhão.

Guc pega o caminhão.

Ri grita, enraivecido: Nãão!

A Figura 8.11 apresenta a distribuição das diversas reações à oposição separadamente por grupo cultural e gênero. Observa-se, nos dois grupos culturais e gêneros, alta freqüência das respostas de ceder ao desejo do outro e de negativa simples. Entretanto, entre os meninos ubatubanos prevaleceu a agressão física e, entre suas colegas, a insistência também apareceu com grande freqüência.

Meninos São Paulo

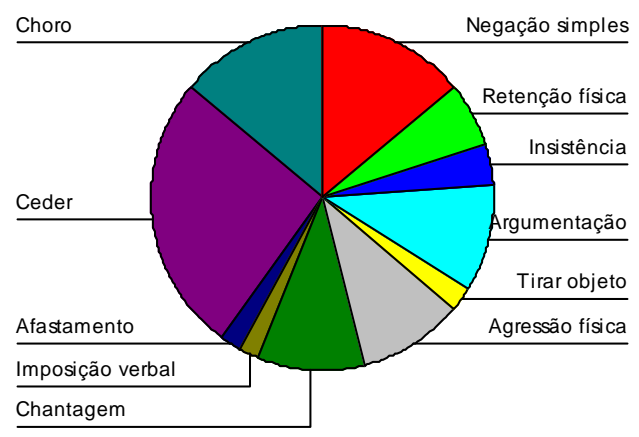

Meninos Ubatuba

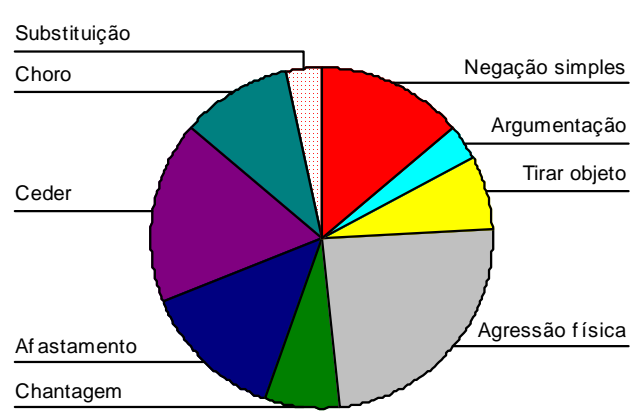

Meninas São Paulo

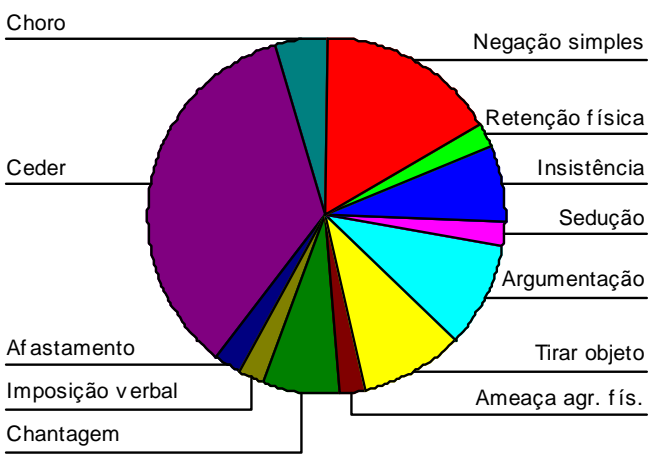

Meninas Ubatuba

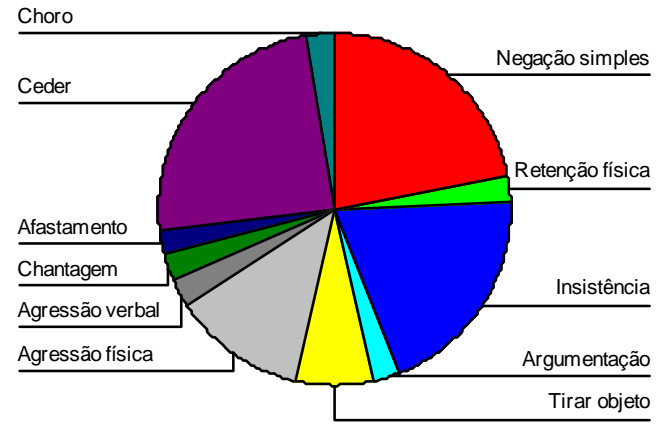

Figura 8.11. Distribuição das reações à oposição, conforme grupo cultural e gênero. 
Tomando-se as proporções de respostas à oposição isoladamente nas diversas categorias em que foram classificadas, procedeu-se a três análises multivariadas (MANOVAs) $2 \times 2$ : uma para as categorias de respostas coercitivas, outra para as não coercitivas e uma terceira para os comportamentos classificados como reações evitativas. A MANOVA calculada para apurar efeito de origem e de gênero sobre as categorias de respostas não coercitivas revelou efeito significativo de gênero (Lambda de Wilks $=0,691, F_{5,31}=2,772, p<0,05$ ). Análises univariadas subseqüentes indicaram que tal efeito se deu sobre a categoria insiste $\left(\mathrm{F}_{1,35}=8,709, \mathrm{p}<0,01\right)$, em que as meninas superaram os meninos (Figura 8.12).

A MANOVA calculada para apurar efeitos de origem e de gênero sobre as categorias de respostas coercitivas revelou efeito positivo, marginalmente significativo, de origem (Lambda de Wilks $\left.=0,408, \mathrm{~F}_{6,30}=2,040, \mathrm{p}<0,10\right)$. Análises univariadas subseqüentes indicaram que tal efeito se deu sobre a categoria agride fisicamente $\left(\mathrm{F}_{1,35}=7,216, \mathrm{p}<0,01\right)$, em que as crianças de Ubatuba superaram as de São Paulo (Figura 8.12).

A MANOVA para apurar efeito de origem e gênero sobre respostas evitativas revelou efeitos positivos, marginalmente significativos, de origem (Lambda de Wilks $=0,776, \mathrm{~F}_{4,32}=$ 2,312, $\mathrm{p}<0,10$ ) e de gênero (Lambda de Wilks $=0,795, \mathrm{~F}_{4,32}=2,060, \mathrm{p}=0,10$ ). Análises univariadas subsequientes indicaram efeitos marginalmente significativos de origem sobre as categorias isola-se ou afasta-se $\left(\mathrm{F}_{1,35}=3,492, \mathrm{p}<0,10\right)$ e cede $\left(\mathrm{F}_{1,35}=3,279, \mathrm{p}<0,10\right)$, e de gênero sobre as categorias cede $\left(\mathrm{F}_{1,35}=3,082, \mathrm{p}<0,10\right)$ e chora $\left(\mathrm{F}_{1,35}=3,880, \mathrm{p}<0,10\right)$. Na categoria afasta-se, as crianças de Ubatuba superaram as paulistanas e essas excederam as primeiras na categoria cede. Quanto às diferenças de gênero, as meninas excederam os meninos na categoria cede, e esses as superaram na categoria chora (Figura 8.12). 


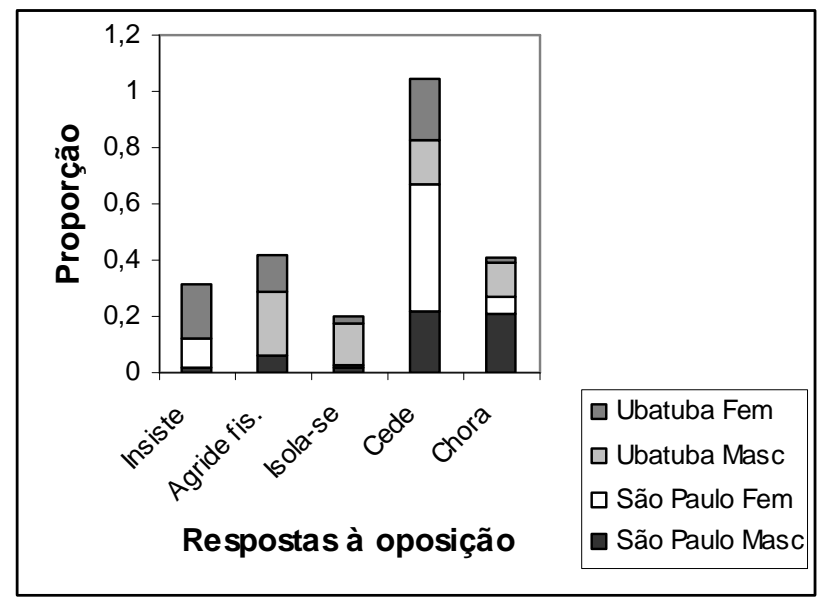

Fig 8.12.Proporções de reações à oposição em que houve diferenças estatisticamente significativas.

Encontram-se, na literatura, várias referências à insistência como tática usada durante os conflitos. Eisenberg e Garvey (1983), por exemplo, estudando crianças de dois anos e dez meses até cinco anos e sete meses de idade, encontraram que a estratégia mais freqüentemente empregada para conseguir os objetivos num conflito era a insistência. Laursen e Hartup (1989) relatam que há crianças cujos comportamentos insistentes superam as negociações e tendem a abreviar o final do conflito. Nossos dados revelaram que insistir foi relativamente freqüente apenas entre as meninas, principalmente entre as ubatubanas. Shantz (1987) comenta que agressão e insistência não costumam ser práticas bem sucedidas na condução de um conflito. Alguns exemplos de nossas crianças ilustram como a insistência nem sempre funciona, podendo irritar a criança para a qual a insistente se dirige.

1) Yo vai até o gira-gira e Ca não pára de rodar para ela subir.

Yo grita três vezes: Pára! e Ca não pára.

Yo chama a professora que pede para Ca parar.

Ca pára e Yo demora a subir.

Yo fica esperando que Ca rode o gira-gira. Essa não o roda enquanto Yo está sentada.

Yo desiste e vai até o outro gira-gira.

2) Ca empoleira-se entre duas traves do trepa-trepa e escreve seu nome numa folha papel, sorrindo.

Mga dirige-se a ela: Me empresta?

Ca (firmemente): Não. É meu.

Evita que Mga tire o papel de sua mão. 
Mga chama a educadora, que diz que todos devem poder brincar com a caneta e o papel.

Ca assume uma postura "manhosa" (balançando o corpo, cabeça baixa, sorrindo).

Educadora: Vamos, Ca. Empresta um pouco pra eles... isso não é só pra você; ele (estagiário) deu isso pra todos.

Ca encosta-se no corpo da educadora, ainda manhosamente, não cedendo.

A educadora pega o papel e a caneta e os dá a Mga.

Mga: Olha Ca, depois dele, vai ser eu e depois você de novo, tá?

Ca apenas observa, ainda manhosa.

Ca tenta pegar a caneta novamente, sem esperar sua vez.

Mga: Calma, Ca Ainda não!

Ca tenta novamente.

Mga: Espera sua vez.

3) Yo diz a Pa: Pa, me dá a pá; a gente precisa dela. Me dá. Me dá um pouquinho. Me dá, vai, Pa!

Pa: Não.

Yo pega um objeto substituto.

A alta incidência da reação de ceder diante da oposição indica que muitos dos conflitos se encerraram após a primeira resposta à oposição, já que não havia por que continuá-lo se o adversário cedeu. No que tange às diferenças de gênero, observa-se um aparente paradoxo: enquanto as meninas utilizaram-se mais de insistir e de ceder, os meninos utilizaram-se mais de chorar. Considerando-se que, através de suas respostas, as crianças estão tentando atingir seus objetivos e, ao mesmo tempo, manifestando reações à frustração, insistir significa tentar novamente, ceder representa abandonar seus objetivos e chorar teria um duplo significado: de mostrar que a criança está desapontada, frustrada, mas também disposta a obter seus objetivos. Embora a frequiência absoluta do comportamento de chorar tenha sido pequena, nessa estratégia, os meninos superaram as meninas, mostrando que para os dois grupos estudados a expressão popular "homem não chora" teve pouca força na determinação de seu comportamento. Entretanto, esta não pode ser considerada uma regra, principalmente entre as crianças de Ubatuba, como pode ser ilustrado pelo seguinte episódio.

Três meninos carregam um tronco muito grande. Chegam mais três para ajudar. Um deles empurra o tronco, que bate na perna de Ig.

Ig cai no chão e chora:

Ya diz a Ig: Seu bicha, bicha!

Outros o chamam de bicha. (a observadora procura Ig para saber o que houve; ele conta onde se machucou)

Outros entoam: Bicha, bicha ...

Ig - Quem chora é bicha. Eu não choro.(E, contendo o choro, passa a brincar com um colega de rolar no chão.) 
Esse episódio isolado, contudo, ocorreu num determinado subgrupo de meninos ubatubanos com comportamento mais prototipicamente masculino, diferente de outro subgrupo mais passivo e entristecido em suas reações, conforme vimos em exemplos anteriores.

Acreditamos que a explicação mais viável para a alta incidência de choro entre os meninos é a de que essa é uma reação mais comum para as táticas pesadas de agressão física, que foram bastante freqüentes como estratégia masculina de oposição.

As crianças de Ubatuba utilizaram-se mais dos expedientes de agredir fisicamente e de afastar-se, novamente duas categorias que envolvem manifestação corporal. As crianças de São Paulo cederam mais do que as de Ubatuba. Pode-se considerar que as conseqüências para o conflito de ceder e de afastar-se são muito semelhantes. Contudo, seu significado para as relações pode ser diferente. Ceder pode significar preocupar-se com as conseqüências dos conflitos para o relacionamento; afastar-se pode significar apenas desistir de levar adiante o conflito. Nessa medida, podemos considerar que as crianças de São Paulo, em especial as meninas, comportaram-se dentro das expectativas de que meninas tenderiam a se preocupar mais com a preservação das relações. Isolar-se e afastar-se predominou no subgrupo de meninos de Ubatuba com maiores dificuldades de interação com seus pares.

Outro aspecto que merece ser comentado foi a maior frequiência de agressão física entre meninos e meninas de Ubatuba, quando comparadas especialmente com as meninas de São Paulo. Esses dados confirmam a mesma tendência apresentada em relação às estratégias de oposição, que efetivamente instalam o conflito. No elo inicial dos conflitos, todavia, meninos de São Paulo mostraram-se também bastante agressivos. Se maior agressividade explícita por parte dos meninos é esperada em vista de dados já comentados da literatura - meninas são mais prósociais e meninos, mais agressivos e encorajados a permanecerem firmes em suas posições (Chung \& Asher, 1996) -, o índice relativamente alto de retaliação física apresentado pelas meninas de Ubatuba, quando comparadas com as de São Paulo, é que contraria a regra. Esse dado é compatível com as características particulares deste subgrupo de meninas. Interessante é observar que, entre as ubatubanas, as reações agressivas não se incompatibilizaram com as prósociais, o que indica que ao menos parte do subgrupo feminino de Ubatuba denotava preocupação com a continuidade da relação ou - o que acreditamos ser mais provável - que ambas as reações se manifestaram concomitantemente nas meninas deste grupo peculiar. 
Uma hipótese aventada por Maccoby (1996) para explicar os dados encontrados na literatura euro-americana, segundo os quais meninas apresentam estratégias mais construtivas do que meninos no manejo de conflitos, diz respeito ao tamanho de grupo preferido pelas crianças. Segundo a autora, as meninas, por interagirem mais em díades e tríades, relacionar-se-iam preferencialmente com amigas, enquanto meninos, em grupos maiores, mais provavelmente interagiriam com não-amigos. Essa explicação, contudo, não se aplica a nossos dados, uma vez que constatamos que a frequiência de interação em díades foi equivalente entre meninos e meninas dos dois grupos culturais e que não foi encontrada, nos dados analisados até agora, preponderância significativa de emprego de estratégias afiliativas por parte das meninas.

Uma hipótese mais viável para explicar diferenças de reação entre meninos e meninas seria a de que, na ameaça de perderem status, os meninos reagiriam na forma de contra-coerção. Maccoby (1996), relatando que os objetivos dos meninos nos conflitos seriam, mais provavelmente, controlar seu resultado (vencer), sugere que esta seja uma dinâmica prioritariamente masculina. Miller et al. (1986) verificaram ser mais provável que meninas apresentassem comportamentos que tendiam a aliviar o conflito e que meninos usassem táticas mais pesadas e confrontantes Nesse sentido, as meninas de Ubatuba teriam revelado ambas as tendências: dominar e apresentar reações que garantissem a continuidade da relação. Com efeito, Miller et al. afirmam que, embora haja diferenças, há também grande superposição no comportamento de garotos e garotas e que é possível que haja mais diferenças de ênfase no comportamento de crianças de ambos os sexos do que de qualidade. Segundo os autores, garotos e garotas não são diferentemente manipuladores, apenas usam meios diferentes: meninos utilizam-se de expedientes mais diretos e meninas, mais indiretos.

\subsubsection{Desenlaces}

Na categorização de conflitos adotada, o desenlace, considerado por alguns autores como resolução (Shantz, 1987; Laursen et al.,1996) ou como estratégia de resolução do conflito (Murphy \& Eisenberg,1996, 2002), é a etapa final que o faz cessar num determinado tempo. Como não podemos considerar que os conflitos tenham sido efetivamente resolvidos e sim cessados ou interrompidos num dado período de tempo, optamos pelos termos desenlace ou desfecho. Encontra-se na Figura 8.13 a distribuição dos diversos desenlaces conforme origem e 
gênero. Pela Figura 8.13, observa-se que, para todas as crianças, com exceção dos meninos de São Paulo, os expedientes mais utilizados para o desenlace de episódios de conflito foram afiliativos e de neutralização do conflito. Entre os meninos de São Paulo, houve uma proporção maior de desfechos coercitivos. Lembremos que incluímos na categoria neutralização de conflitos situações em que uma das partes ou todos os colegas envolvidos na disputa - sem que houvesse razão aparente, nem negociação - desistiram de se opor, desviaram o foco da atenção para outro alvo ou passaram a brincar juntos ou com outro companheiro. Foram também incluídos nessa categoria os casos em que, estando duas ou mais crianças em oposição, uma terceira passou a interagir com a díade ou grupo e, mudando o foco de atenção, fez cessar a disputa.

A alta freqüência de desfechos por neutralização nos leva a pensar que, para estas crianças, uma forma eficaz de encerrar o conflito tenha sido "mudar de assunto", isto é, não perpetuar o desentendimento até o ponto em que efetivamente houvesse uma resolução. Dell'Aglio e Hutz (2002) também encontraram, em crianças de oito anos, que a distração foi a estratégia mais utilizada para lidar com emoções criadas por situações geradoras de estresse A alta incidência de ceder e de afastar-se como formas de reação à oposição também pode ser interpretada nesse sentido. Observamos fragmentos de conflito e é bem possível que, como a neutralização não implica necessariamente resolução, o conflito latente não resolvido possa ter voltado a manifestar-se posteriormente. Seria, entretanto, necessária outra metodologia para se acessar este dado.

A MANOVA aplicada para se verificar efeitos de origem e de gênero sobre os tipos desfecho não revelou resultados significativos. No entanto, alguns achados a respeito da distribuição do desenlaces nos dois grupos culturais e gêneros merecem ser comentados. As soluções afiliativas, em que uma das partes ou ambas as crianças envolvidas adotam atitudes que visam a preservar a relação (convite para brincar, negociação, agrado, oferta simbólica, pedido de desculpas), foram também bastante freqüentes em todos os subgrupos, embora em menor proporção entre os meninos paulistanos. Os desfechos afiliativos, somados àqueles por neutralização do conflito, atingiram de 50 a $70 \%$ dos casos, conforme o subgrupo analisado, muito embora, como observaram Magalhães (1995), em crianças menores, e Bussab (2003), nas 

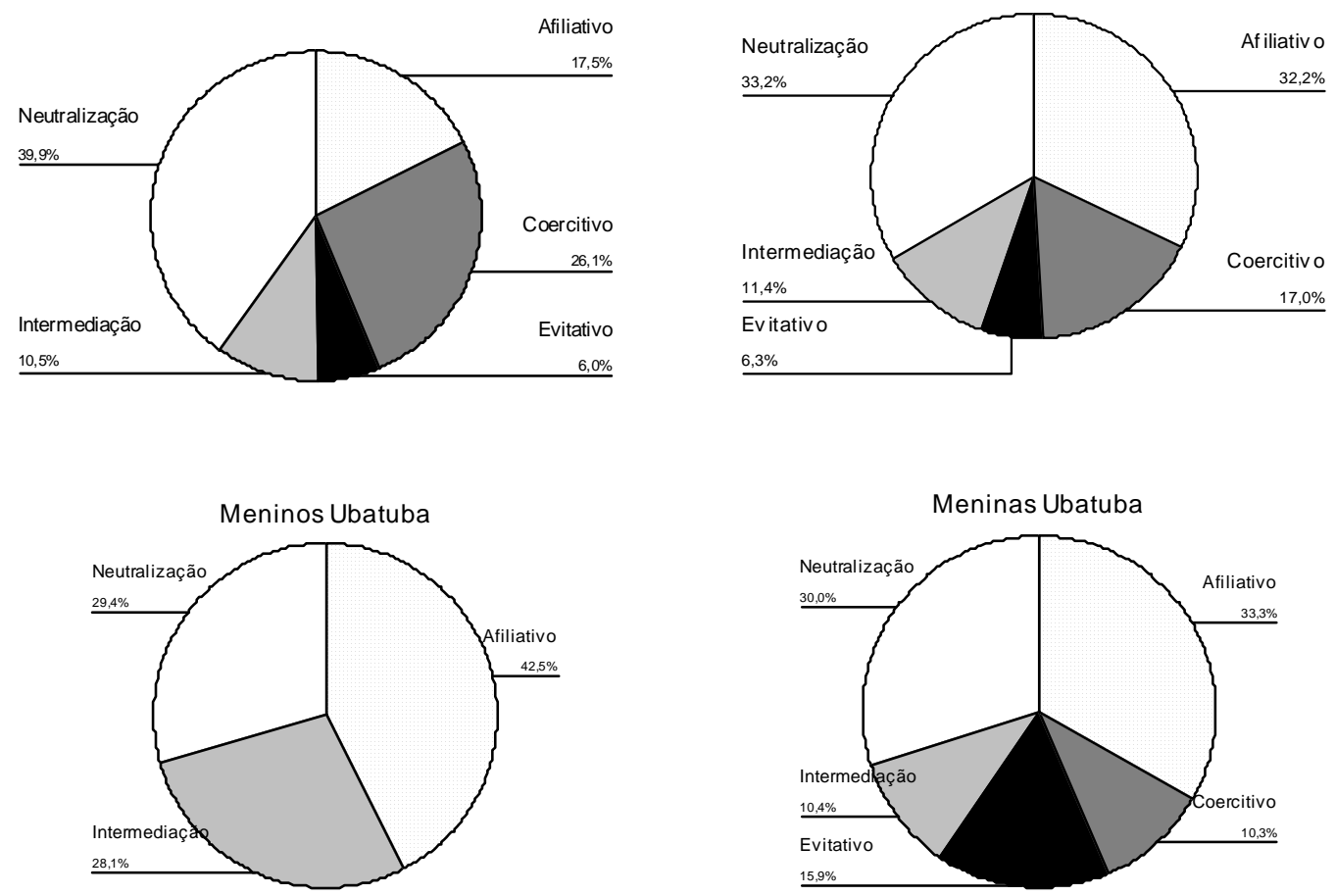

Figura 8.13. Distribuição dos desenlaces conforme origem e gênero.

crianças de São Paulo, episódios de conciliação tenham sido raros. Maccoby (1996) argumenta que é possível que a maneira como o conflito é resolvido dentro de uma particular relação diádica seja um produto dos estilos individuais dos dois componentes da díade e que não são apenas as emoções de raiva, tristeza e hostilidade que entram num conflito, mas também os afetos positivos, que parecem prevalecer no final.

As demais categorias apareceram com pouca freqüência, com exceção de intermediação de terceira parte em Ubatuba. As intermediações observadas foram geralmente solicitadas à professora e partiram principalmente dos meninos ubatubanos. A grande incidência de intermediações de terceira parte a pedido das crianças tanto poderia indicar falta de confiança nos recursos próprios para se defenderem como meramente um hábito de recorrer aos adultos para o julgamento de desavenças. A primeira possibilidade aventada é plausível, tendo em vista que os meninos ubatubanos usaram táticas mais pesadas durante os conflitos - o que justificaria maior necessidade de intervenção por parte do adulto. Chung e Archer (1996) afirmam que a 
intervenção de terceiros seria mais custosa para meninos do que para meninas em termos de aceitação por parte do grupo de pares. Parece não ter sido esse o caso verificado nos grupos estudados. Para melhor conhecimento do que ocorre com intervenções de terceiras partes - se foram específicas deste grupo ou resultantes de uma prática cultural mais disseminada -, seria muito interessante estender esta pesquisa para outros lugares públicos e domicílios do município.

Evidencia-se, em suma, que a maior parte de desenlaces dos conflitos foi amigável, encontrando-se um ligeiro predomínio de desfechos coercitivos apenas nos meninos de São Paulo $\left(\mathrm{t}_{17}=2,097, \mathrm{p}=0,06\right)$, quando comparados aos de Ubatuba. É provável que, não se viabilizando uma solução negociada, seja efetivamente mais adaptativo desistir do conflito, ao menos para os pré-escolares estudados. As conseqüências de uma solução imposta seriam, provavelmente, mais nocivas para as relações interpessoais horizontais, relativamente duradouras, existentes entre estas crianças. Laursen et al. (1996) argumentam que conflitos que terminam em negociação são mais construtivos do que os resolvidos através de coerção. Podese explicar o maior número de desenlaces coercitivos nos meninos de São Paulo pelo fato de disporem de um número maior de possibilidades de escolha de parceiros de brincadeira, pois brincavam no pátio em conjunto com mais vinte crianças de sua idade. Ou seja, os paulistanos poderiam permitir-se mais rompimentos, pois tinham mais parceiros alternativos de relacionamento.

Do ponto de vista cognitivo, segundo a classificação proposta por Shantz (1987), nossas crianças estariam situadas no nível zero de solução de conflitos, que ocorre dos 3 aos 7 anos. Conforme já assinalamos, a autora considera que, nesse nível, os conflitos são resolvidos através da interrupção da interação ou de força física. Segundo Shantz, seria no nível um que apareceria uma apreciação dos efeitos psicológicos e interacionais dos conflitos, embora esses não sejam ainda entendidos como multilaterais. Nesse nível, surgiriam as soluções em que uma das partes cede para que a outra se sinta melhor. Nossos dados permitem-nos supor que, em ambos os grupos culturais, muitas crianças já estariam no nível um da classificação de Shantz, indicando ou que elas eram precoces ou que esse nível surge mais cedo no desenvolvimento do que supôs a autora.

As conhecidas diferenças de gênero - em que se considera que meninas apresentam soluções mais afiliativas e meninos, mais coercitivas - apareceram apenas no grupo de São Paulo, embora sem significância estatística. Segundo Murphy e Eisenberg (1996), meninas de 
dez a onze anos de idade relataram estar mais empenhadas com a manutenção do relacionamento e com o compromisso, ao resolverem um conflito, enquanto os meninos da mesma idade estavam mais preocupados em manter o controle, com a auto-assertividade e com a hostilidade. Hartup et al. (1993), estudando crianças de nove a dez anos de idade, relatam que meninas procuraram trazer concordâncias durante e após o conflito, mostrando maior compromisso com o bem-estar do outro do que seus colegas de sexo masculino.

Em vista desses dados, seria de se esperar que os meninos apresentassem mais desfechos coercitivos. Fato surpreendente foi não ter havido nenhum desfecho imposto entre os meninos ubatubanos, que, nos elementos analisados até agora, revelaram-se mais agressivos e truculentos do que os paulistanos. Uma explicação viável para esse resultado é o temor de que suas respostas agressivas, se levadas às últimas conseqüências, pudessem trazer um rompimento que não seria vantajoso para crianças com tão poucas opções de relacionamento no grupo escolar. Esse argumento contraria a hipótese já levantada de que essas crianças, por questões culturais, teriam menor temor de apresentar reações hostis. Poder-se-ia também supor que as táticas mais agressivas dos ubatubanos, sendo culturalmente mais comuns, não seriam levadas tão a sério pelos colegas, que praticamente as ignorariam, no intento de logo pôr fim à situação conflituosa. É ainda possível conjecturar que, apesar de interromperem o conflito de modo não coercitivo, na primeira oportunidade, os ubatubanos voltassem a conflitar com o colega que foi agressivo numa situação anterior, ou seja, que tendessem a "pagar na mesma moeda" posteriormente. O método que utilizamos não permite comprovar essa ultima hipótese, pois seria necessário, para isso, investigar a história dos conflitos no grupo. Quaisquer afirmações mais categóricas para explicar o fato de os meninos ubatubanos não terem apresentado soluções coercitivas só poderiam ser feitas mediante o uso de outra metodologia e estendendo o levantamento de dados por um tempo maior e para outros grupos de crianças caiçaras.

A importância das diferenças culturais, inclusive de sua evolução na história das relações interpessoais, é inquestionável. Verbeek et al. (2000), por exemplo, citam estudos que constataram que crianças mexicanas que viviam nos Estados Unidos tendiam a privilegiar soluções de conflito integradoras, enquanto as anglo-americanas privilegiavam a afirmação de poder para pôr fim a uma disputa. É provável que, quando comparadas com as ubatubanas, as crianças de São Paulo apresentem um padrão de comportamento mais semelhante ao das crianças euro-americanas, em virtude das influências culturais sofridas mais diretamente pelo grupo paulistano - mais exposto a influências da mídia e a valores de uma sociedade mais 
complexa e globalizada -, muito embora a distribuição dos diversos desfechos entre meninas ubatubanas e paulistanas tenha sido muito semelhante.

\subsubsection{Alianças}

A formação de alianças é um relevante aspecto das relações interpessoais, evidenciado na evolução e resolução de conflitos (Hawley, 2002). Sua importância é inegável quando se trata de relações entre grupos, em que as alianças internas devem fortalecer-se no combate a agrupamentos estranhos ou inimigos. Muitos estudos têm sido feitos com alianças em primatas não humanos (Aureli \& de Waal, 2000), sendo poucos os trabalhos dedicados a alianças em conflitos de pré-escolares (Magalhães, 1995).

Uma ANOVA 2 x 2 calculada para testar efeito de origem e de gênero sobre a proporção entre total de alianças e conflitos não revelou resultados estatisticamente significativos, provavelmente devido a sua incidência relativamente rara e a sua concentração em poucas crianças: $45 \%$ das crianças paulistanas e $32 \%$ das ubatubanas apresentaram alianças. Apesar do número pequeno de alianças, esse foi, em média, superior ao encontrado por Magalhães (1995) em crianças de 18 a 30 meses, sugerindo que a cumplicidade aumenta com a idade.

Apesar de não se constatarem diferenças significativas nos testes estatísticos, observa-se, pela Figura 8.14, que as alianças foram mais frequientes no grupo de Ubatuba. Considerando o conjunto de dados apresentados até agora, surge mais uma evidência de que valores de solidariedade parecem ter-se manifestado mais em crianças desse grupo do que nas de São Paulo. É interessante verificar que, ao lado de muitas agressões físicas nas etapas de instigação do conflito e de resposta a oposições, coexistem, neste grupo, soluções pró-sociais e alianças. Poder-se-ia dizer até que essas crianças se caracterizaram por reações extremadas, conforme a etapa do conflito enfocada. É possível que esses dados se expliquem em parte pelas alternativas mais polares viabilizadas por uma sociedade construída sobre bases menos complexas. Nessas sociedades, regidas por valores mais tradicionais, não haveria tantas gradações entre o construtivo e o destrutivo, ou entre o certo e o errado, o recomendável e o condenado. 


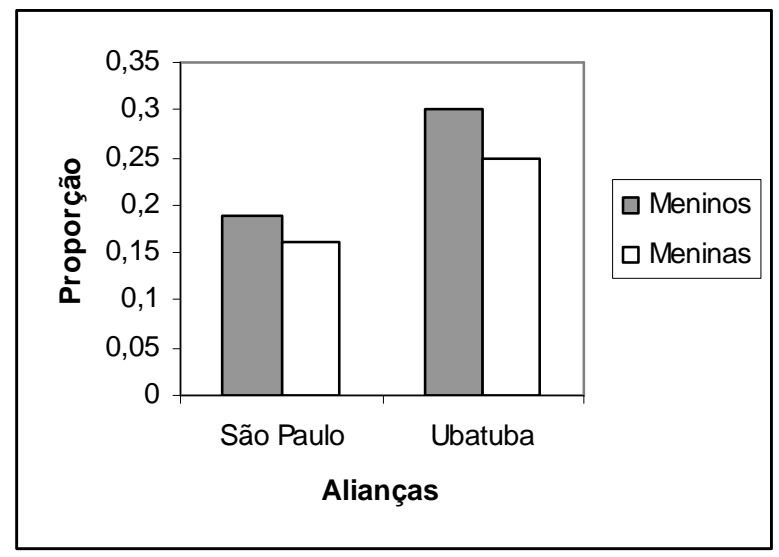

Figura 8.14. Proporção de alianças em relação ao total de conflitos, segundo grupo cultural e gênero.

Para apurar se havia diferenças entre os grupos quanto à incidência de alianças com o alvo e com o agente, dividiu-se o número de alianças com o alvo e de alianças com o agente pelo número total de alianças para cada sujeito focal, obtendo-se índices proporcionais. A MANOVA calculada para testar o efeito de origem e de gênero sobre essas proporções não revelou efeito significativo, o que equivale a dizer que a distribuição de alianças, seja com o alvo, seja com o agente, foi semelhante nos dois grupos culturais e gêneros (Figura 8.15).

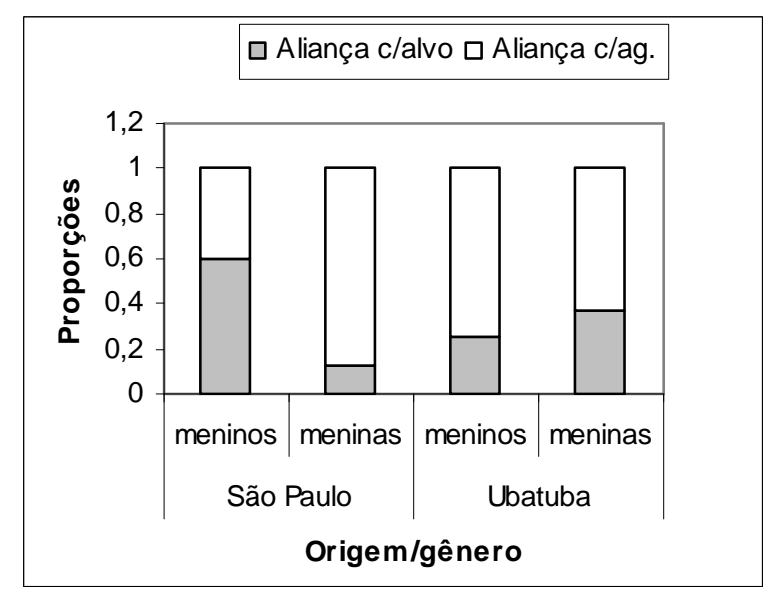

Figura 8.15. Proporções de alianças com o alvo e com o agente em relação ao total de alianças nos dois grupos culturais e gêneros.

Embora testes t pareados entre alianças com o alvo e com o agente tenham mostrado diferenças significativas apenas no grupo de meninas de São Paulo $\left(\mathrm{t}_{9}=5,196, \mathrm{p}<0,05\right)$, 
observa-se, pela Figura 8.15, que, com exceção dos meninos paulistanos, foram mais comuns as alianças com o agente. Magalhães (1995), estudando crianças de 18 a 30 meses, também encontrou que alianças com o agressor foram mais freqüentes do que com a vítima. Esperaríamos, contudo, em vista da maior preocupação das meninas com o bem estar dos outros, que houvesse tendência inversa, ou seja, que elas mostrassem mais solidariedade com as vítimas do conflito. Contudo, deve-se ponderar que a vítima do conflito não é necessariamente a parte prejudicada.

A complexidade e a dinâmica das interações, em especial das que envolvem conflitos e alianças, também dificulta a forma dicotômica de classificação das pessoas como agentes ou como alvos. Algumas vezes, as alianças mudam de lado, já que pode ocorrer que o alvo de um conflito passe a ser agente de outro ou que um aliado mude de opção durante o conflito ou que, durante um mesmo episódio, uma mesma criança atue como agente e alvo ou, ainda, que não possa ser considerada nem vítima nem perpetradora do conflito. Os exemplos abaixo ilustram essa dinâmica das alianças.

1) Bra (dirigindo-se ao grupo): - Ele (Ga) bateu no meu olho.

Todos olham para Ga, mas não fazem nada.

Bra, ainda desconsolada, vaga pelo pátio.

Ga chega: Não fiz nada, tá Bra?

Bra não responde e anda pelo pátio até a balança.

Bra aproxima-se de Vi Fe na balança, olhando-a ameaçadoramente.

Bra diz a Vi Fe - Não vai sair daí?

Ga, que havia brigado com Bra, aproxima-se e ameaça Vi.

Bra para Vi Fe - Você quer sair.

Ga-Se você não sair, dou porrada.

Bra para Vi Fe - Quer ver? Chintalha, chintalha (ameaça dar soco na colega).

Ga (repete): Chintalha, chintalha (e finge dar soco em Da).

Da repete:Chintalha, chintalha!

Bra, ao ver outra criança chorando, acusa os meninos e passa a correr atrás deles. Vira uma brincadeira de perseguição. Às vezes, ela pára e finge dar chutes no ar.

2) Vi-Dá,Gu, o celular (máquina de calcular).

Mga chega e tenta pegar a máquina; Gu a segura.

Mga tenta pegar o objeto, dizendo: Dá pra mim, não vou dar pra ele.

$V i$-Você tem que me dar.

Mga tira a máquina de Gu e a dá a Vi.

Gu corre atrás de Vi e o segura.

Vi dá a máquina para Mga.

Mga e Gu disputam a máquina. Gu a tira. 
$V i-D a ́, G u !$

Gu sai. Mga o segue e faz movimentos e sons de socos e tenta pegar a máquina.

Gu faz cara de enraivecido.

Vi Ra está próxima da cena e diz: Vou falar para a professora se vocês começarem a brigar.

Mga a Gu: Vou puxar seu cabelo!

Gu segura a máquina.

$V i-D a ́, G u$.

Mga se esconde; depois, aparece com cara de brava e finge dar soco em $\mathrm{Gu}$,

dizendo: Gosta que eu te machuque? Dá para ele.

Gu a Mga (empurrando-a): Pára de me seguir.

Vi pega outro brinquedo.

Gu olha para Mga com cara de bravo e diz: Você vai ver se a professora não te dá uma porrada.

Mga: Professora não dá porrada.

Gu - Eu vou no carro do meu pai. É rápido.

Vi - Eu vou chamar a polícia.

As variações presentes nesses episódios não só demonstram como as crianças mudam rapidamente de posição e de atividade, mas também como a brincadeira é sempre atrativa para dar fim a um conflito. É provável que relações de amizade e outros vínculos formados na história do grupo, que desconhecemos, atuem no momento de fazer alianças. As variações individuais também são grandes: algumas crianças mostraram-se solidárias com o alvo, outras apenas com o agente, outras, ora com o agressor, ora com a vítima e outras não fizeram alianças. Para se apurar a natureza dessas complexas relações e da rede de significados (Carvalho \& Rubiano, 2004) que operam nessas situações seriam necessárias análises complementares com outra metodologia.

\subsection{Síntese}

Como já constatamos em relação às brincadeiras, houve, além de muitos pontos em comum revelados nos episódios de zombaria e de conflito apresentados pelas crianças dos dois grupos culturais e gêneros, também interessantes aspectos divergentes. Entre as semelhanças, destacou-se a freqüência de provocações e de conflitos. As principais diferenças evidenciaramse na análise dos elementos dos conflitos, salientando-se as reações mais diretas e extremadas das crianças de Ubatuba, quando comparadas às de São Paulo. Constataram-se, contudo, outras peculiaridades, resumidas a seguir. 
Zombaria. A forma não verbal de provocação ocorreu com maior freqüência no grupo de Ubatuba e a verbal, entre as crianças de São Paulo. Predominaram desenlaces positivos após atos de provocação, muito embora tenha havido também reações agressivas e de revide. De maneira geral, foram observadas poucas provocações, o que nos leva a supor que esse é um tipo de comportamento pouco comum na faixa etária das crianças estudadas, provavelmente em razão da complexidade cognitiva envolvida, tanto na emissão quanto na compreensão da mensagem interacional, principalmente em função de seu caráter ambíguo.

Freqüência de elos ou unidades de conflitos. Não houve diferenças significativas entre os grupos culturais e gêneros quanto ao número de conflitos observados. Com respeito aos elos do conflito, verificaram-se diferenças de gênero, principalmente pelo maior número de elos apresentado nos conflitos envolvendo meninas paulistanas - constatação que sugere que elas tenham prolongado mais os conflitos, principalmente através de táticas verbais de insistência e de argumentação.

Motivos. Nos dois grupos culturais e gêneros, prevaleceu como motivo dos conflitos a disputa por objetos, resultado compatível com a idade das crianças. Análises estatísticas revelaram que as meninas apresentaram mais disputas por espaço, vez ou lugar na fila do que os meninos e que esses mostraram mais conflitos originados por ameaças ou agressões aparentemente injustificadas e por motivos ignorados do que suas colegas. Não foram constatadas diferenças na incidência dos diversos motivos em função do grupo cultural.

Estratégias de oposição. Nos dois grupos culturais e gêneros, predominaram estratégias de oposição coercitivas. Assim como o motivo de conflito mais freqüente foi a disputa por objetos, a estratégia de oposição mais comum foi, no grupo de Ubatuba e no subgrupo de meninos paulistanos, tirar ou tentar tirar o objeto do parceiro. Entre as meninas de São Paulo, houve uma melhor distribuição das diversas estratégias de oposição.

As crianças de São Paulo superaram as de Ubatuba nas categorias agredir verbalmente ou zombar, ameaçar retirar a amizade e fazer imposições verbais. A distribuição de táticas de oposição reafirma a tendência das crianças de Ubatuba de utilizarem mais estratégias envolvendo contato proximal (agredir fisicamente, tirar o objeto) do que as de São Paulo e essas, mais táticas verbais (argumentar, impor, agredir verbalmente e ameaçar retirar a amizade) do que as primeiras. Entre as meninas de São Paulo, foram constatadas mais estratégias pró-sociais 
do que entre seus colegas, confirmando dados da literatura obtidos com crianças euroamericanas, que encontraram diferenças entre os gêneros nesse sentido.

Respostas à oposição. Constatou-se que as meninas de Ubatuba superaram os meninos e os garotos paulistanos excederam ligeiramente suas colegas nas reações não coercitivas à oposição. Nesse componente do conflito, as meninas paulistanas foram o grupo que apresentou maior número de respostas evitativas e os meninos ubatubanos revelaram predomínio de reações evitativas sobre as afiliativas Discutindo a possibilidade de que respostas evitativas tenham também uma finalidade afiliativa, conjectura-se que a reação das meninas paulistanas e dos meninos ubatubanos possa estar ligada a objetivos pró-sociais.

Analisando-se as categorias de resposta à oposição separadamente, observou-se que as crianças de Ubatuba apresentaram maior freqüência de respostas de agressão física do que as paulistanas. Na categoria afasta-se, as ubatubanas superaram as paulistanas e essas excederam as primeiras na categoria cede. As meninas suplantaram os meninos nas categorias insiste $e$ cede, e esses as superaram na categoria chora.

Desenlaces. A análise dos desfechos dos conflitos indicou que a maioria deles terminou sem rupturas e sem outras conseqüências negativas imediatas. Com exceção do grupo de meninos paulistanos, que apresentou um número maior de desfechos coercitivos, predominaram os desenlaces afiliativos e por neutralização do conflito. Tal resultado era de se esperar, tendo em vista que, para um grupo de companheiros que interage cotidianamente, é interessante que as relações se mantenham num nível que assegure sua continuidade.

Alianças. Apesar de ter havido um número pequeno de alianças, elas foram ligeiramente mais freqüentes entre as crianças ubatubanas. Com exceção dos meninos de São Paulo, foram também mais freqüentes as alianças com o agente do conflito, embora se tenham encontrado diferenças estatisticamente significativas nesse sentido apenas no subgrupo de meninas paulistanas.

\subsection{Relação entre os componentes dos conflitos}

Diversos autores estabeleceram relações entre os objetivos, os motivos e as emoções envolvidos nos conflitos, como importantes determinantes para sua administração. Hawley (2002) afirma haver grandes diferenças individuais na motivação para controlar recursos; 
Laursen e Hartup (1989) e Maccoby (1996), entre outros, constataram a influência da amizade sobre o desenvolvimento e resolução de disputas: resumidamente, esses autores encontraram que amigos tendem a apresentar encaminhamentos mais afiliativos para os conflitos; Murphy e Eisenberg (2002) estudaram a influência dos objetivos e das emoções envolvidas sobre o desenrolar dos conflitos, constatando que a emoção de raiva tenderia a prolongar as disputas, enquanto a de tristeza tenderia a abreviá-las. Como não medimos nenhuma dessas variáveis diretamente, procuramos estabelecer algumas relações entre os elos dos conflitos para verificar como nossos dados se situam em relação às variáveis que se vêm mostrando importantes na determinação e resolução de conflitos.

\subsubsection{Estratégias preditivas de ameaça e agressão aparentemente Injustificadas}

Uma das mais freqüentes e importantes questões que é foco de preocupação de diversos estudiosos do conflito infantil é sua relação com a agressividade ou agressão (Ballif-Spanvill et al., 2003; Laursen \& Hartup, 1989; Shantz, 1986). Segundo Shantz (1986), enquanto a agressão é definida como qualquer ato em que uma pessoa fere ou tenta ferir a outra (agressão física), ou verbalmente a insulta ou deprecia (agressão verbal), o conflito se caracteriza pela discordância. A Tabela 8.1 indica diferentes estratégias associadas a conflitos iniciados por ameaça ou agressão aparentemente injustificadas, obtidas através de análises de regressão pelo método stepwise.

Alguns autores argumentam que conflitos iniciados por agressão dariam ensejo a estratégias agressivas e a retaliação (Murphy \& Eisenberg, 2002; Rose \& Archer, 1999). Entretanto, observamos que nem sempre isso ocorre. Apenas no grupo de meninos ubatubanos, observou-se esse efeito. Entre as meninas de Ubatuba, nenhuma estratégia associou-se a esse tipo de ensejo para o conflito. A estratégia dos meninos de São Paulo preditiva de conflito por motivo de agressão foi a imposição verbal, uma tática que, ao lado da argumentação, pode ser considerada bastante adequada e pró-social no enfretamento de conflitos. 
Tabela 8.1. Estratégias de oposição positivamente preditivas de conflitos iniciados por ameaça ou agressão aparentemente injustificadas.

\begin{tabular}{llc}
\hline Gênero/origem & Estratégias preditivas & $F$ \\
\hline Meninos SP & Imposição verbal & $\mathrm{F}_{1,8}=6,237 *$ \\
Meninas SP & $\begin{array}{l}\text { Argumentação e tomada de posse } \\
\text { do objeto }\end{array}$ & $\mathrm{F}_{1,8}=19,075^{* * *}$ \\
Meninos Ubatuba & Agressão física & $\mathrm{F}_{1,7}=16,824 * *$ \\
\hline $\mathrm{p}<0,05 ; * * \mathrm{p}<0,01 ; * * * \mathrm{p}<0,001$ &
\end{tabular}

Entre as meninas paulistanas, foram preditivas de conflitos ocasionados por agressão as estratégias de argumentação e a tomada do objeto. Enquanto a primeira tática pode ser considerada construtiva, a segunda tem um caráter mais coercitivo e, por vezes, algo agressivo e invasivo. Embora não tenhamos perguntado às crianças seus objetivos durante o conflito, uma interpretação possível seria a de que as estratégias pró-sociais estivessem associadas a objetivos mais amigáveis. Murphy e Eisenberg (2002) apontam que crianças que relatam objetivos amigáveis para resolver um conflito tendem a adotar estratégias construtivas, enquanto aquelas que referem objetivos não amigáveis inclinam-se a usar táticas menos construtivas.

Hawley (2002) salienta que, se, por um lado, pode-se considerar que a agressão é uma das bases para o controle de recursos, observa-se que ela é cada vez menos tolerada à medida que os indivíduos crescem e amadurecem. A autora afirma ser muito mais útil e explicativo aplicar o conceito de dominância social aos indivíduos que detêm os recursos, independentemente da forma como o fazem ou dos meios que utilizam. Nessa perspectiva, embora também não tenhamos medido variáveis relacionadas a dominância e hierarquia social nos grupos, pelos dados da Tabela 8.1, poderíamos inferir que as crianças paulistanas mostraram maior sensibilidade e maturidade nas respostas associadas a conflitos motivados por agressão. A seguir, descrevemos outras relações entre motivos e desenlaces que podem corroborar essa suposição. 


\subsubsection{Relações entre motivos e desenlaces}

Através da análise de regressão múltipla pelo método stepwise, não foram constatados desenlaces preditivos de conflitos iniciados por agressão ou por ameaça aparentemente injustificada. Buscamos, então, outras correlações significativas entre motivos e desenlaces, com o intuito de comparar nossos dados com alguns relatados na literatura (Tabela 8.2).

Pelos dados da Tabela 8.2, pode-se, a um primeiro exame, perceber que, entre os meninos de São Paulo, houve um número muito maior de correlações positivas significativas entre motivos e desenlaces do que entre as demais crianças observadas. Conflitos motivados por excessos nas brincadeiras se associaram a desenlaces mais construtivos, resultado esperado tendo em vista que esse é um motivo de desentendimento geralmente acidental, ou seja, não intencional. Parece que isso foi bem compreendido pelos parceiros dos meninos paulistanos. Disputas por objetos e por controle e dominância social associaram-se tanto a desenlaces

Tabela 8.2. Correlações entre motivos e desenlaces de conflitos conforme grupo cultural e gênero.

\begin{tabular}{clc}
\hline \multicolumn{1}{c}{ Grupo } & \multicolumn{1}{c}{ Correlações } & Coef. Pearson \\
\hline Meninos SP & Brincadeira excede limite X neutralização do conflito & $0,66^{*}$ \\
& Brincadeira excede limite X desenlace afiliativo & $0,67^{*}$ \\
& Disputa por objetos X desfecho coercitivo & $0,65^{*}$ \\
& Disputa por objetos X intermediação de 3 ${ }^{\text {a }}$ parte & $0,64^{*}$ \\
& Disputa por controle social X desfecho coercitivo & $0,71^{*}$ \\
& Disputa por controle social X intermediação de $3^{\text {a }}$. & $0,66^{*}$ \\
& parte & $0,66^{*}$ \\
Meninas SP & Motivo ignorado X desfecho coercitivo & $0,76^{*}$ \\
& Disputa de objeto X neutralização do conflito & $0,75^{*}$ \\
& Disputa por controle social X intermediação de $3^{\text {a. }}$ & \\
Meninos Ubatuba & parte & $0,76^{*}$ \\
Meninas Ubatubata de objeto X neutralização do conflito & Disputa por controle social X desfecho coercitivo & $0,79^{* *}$ \\
\hline
\end{tabular}

$* \mathrm{p}<0,05 ; * * \mathrm{p}<0,01$

coercitivos quanto a intermediação por terceira parte e conflitos por motivo ignorado relacionaram-se a desenlaces coercitivos, sugerindo que situações mais difíceis acabam 
requerendo uma intervenção de terceiro ou uma finalização imposta, conforme exemplos a seguir.

1- Ri percebe que falta uma cerca no jogo da fazendinha. Sai procurando pela cerca e a encontra na mão de Jô, que está dentro do túnel. Ri pede para que Jo lhe devolva a cerca. Jo não responde. Ri vai até a educadora para resolver a questão. Ri volta e diz a Jo: Ela mandou você me dar

Jo levanta-se, vai até a mesa de brinquedos e joga a cerca sobre a mesa com agressividade. Na volta para o túnel, Jo passa por Ri e lhe dá um soco leve. Dan, que acompanhava os acontecimentos, fica bravo com Jô e o segue até o túnel. Lá Dan cochicha algo com Jo e sai correndo pelo pátio. Jô o segue e, ao aproximarse, chuta-o e empurra-o. Dan tenta revidar, mas Jo corre em direção à educadora.

Diante dela, Dan começa a chorar e explica-lhe que Jo tinha batido nele.

A educadora conversa com Jo e o põe de castigo.

2- Ia e Ro discutem a respeito de onde guardar um papel que têm na mão: se na mochila de um ou na de outro.

Ia - Na minha mochila.

Ro - Tá bom, na minha.

Repetem o diálogo, até que Ia conclui bravo: Na minha!

Ro sai para guardar o papel.

3- Ri pega uma peça de Dig.

Dig: Pode me dar. Tava comigo. Me dá.

$R$ - Não tava, não.

Dig (agressivamente): Me dá! (e retira a peça da mão de Ri).

Ri recupera a peça e atira para Dig algumas outras.

Dig (devolvendo, com aparente rancor, as peças que Ri havia jogado para ele): Toma, não quero os seus bloquinho!

Dig (para Ri, irritado): Seu bicha!

A professora chama a atenção de Ri por um episódio anterior em que tinha tomado um carrinho de uma criança mais nova.

Os exemplos acima são todos referentes a episódios de crianças de São Paulo. Shantz (1986) encontrou que, quanto mais as crianças se envolviam em conflitos, mais agressão física aparecia. Só encontramos dado semelhante no grupo de meninos de São Paulo ( $r$ Pearson = 0,67, $\mathrm{p}<0,05$ ), reafirmando a semelhança dos resultados verificados nesse grupo com aqueles das crianças euro-americanas. Ao se analisarem as relações obtidas nos demais subgrupos e 
examinando os dados dos quatro subgrupos como um todo, constatamos algumas inconsistências nas respostas, mais evidentes no caso de disputa por objetos, sem dúvida o motivo mais freqüente, que, entre as meninas de São Paulo e oa meninos de Ubatuba, correlacionou-se com um desfecho mais afiliativo (neutralização), e, entre os meninos de São Paulo, com desenlaces coercitivos e com intermediação de terceira parte. Hawley (2002), como já relatamos, estudando crianças de três a seis anos de idade, sugere que, em pré-escolares, táticas coercitivas e pró-sociais estão altamente relacionadas na efetividade do controle de recursos, não podendo ser consideradas como estratégias opostas. Murphy e Eisenberg (1996), estudando crianças de sete a onze anos, relatam que meninos considerados adequados e com bons níveis de funcionamento social tenderam a mostrar objetivos construtivos e preocupação com os outros na solução de desavenças. As autoras consideram também como fundamental o papel representado pelas diferenças individuais no funcionamento social para a resolução de conflitos.

Os dados da Tabela 8.2, que mostram muitas diferenças entre os grupos, podem ser explicados não só por diferenças individuais, mas também por peculiaridades da microcultura dos grupos de brincadeira. Determinados comportamentos durante os conflitos podem refletir estilos interacionais estabelecidos na dinâmica das relações dentro do grupo. Alguns seriam mais aceitos ou funcionariam melhor do que outros em diferentes contextos socioculturais.

\subsection{Conflitos e sexo do parceiro}

Tendo em vista que as crianças se relacionam diferentemente com companheiros do mesmo sexo e do sexo oposto, procuramos verificar se os conflitos acompanharam essa tendência. Para tanto, inicialmente se computaram os conflitos de cada sujeito focal e o sexo da criança com quem interagiam, obtendo-se índices de parceria com o mesmo sexo e com o sexo oposto. Esses índices foram relativizados, dividindo-se os números obtidos pelos totais de conflitos observados em cada criança. A MANOVA 2 × 2 realizada para verificar efeitos de origem e de gênero sobre as parcerias revelou efeito fortemente significativo de gênero (Lambda de Wilks $\left.=0,623, \mathrm{~F}_{5,31}=21,166, \mathrm{p}<0,001\right)$. $\mathrm{O}$ efeito se deu tanto sobre parceria com meninos, quanto com meninas, com iguais resultados estatísticos $\left(F_{1,35}=21,166, p<0,001\right)$. Naturalmente, meninos conflitaram mais com outros meninos e meninas, com outras meninas (Figura 8.16), 
fato explicável tendo em vista que ambos os grupos relacionaram-se mais com crianças do mesmo sexo, aumentando, assim, a probabilidade de entrarem em conflito com elas.

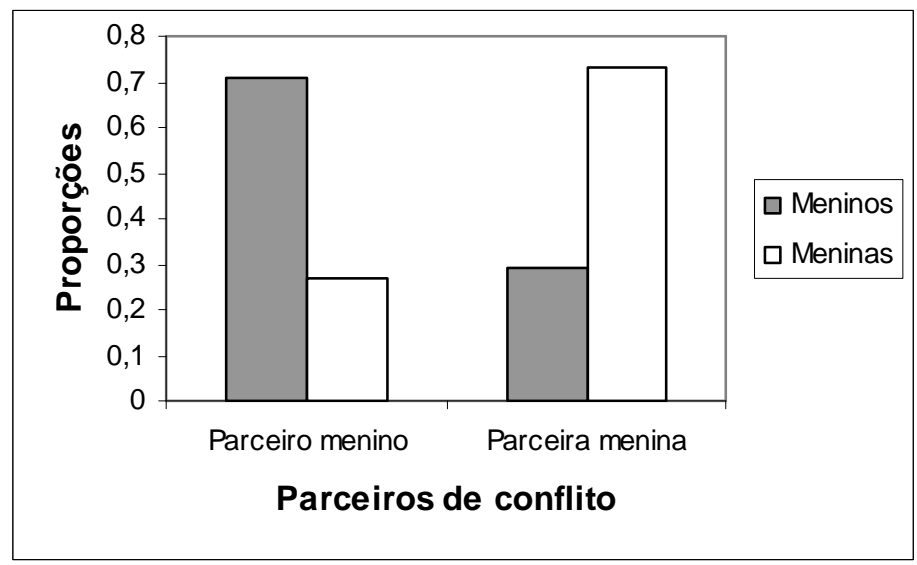

Figura 8.16. Conflitos conforme sexo do parceiro.

Bussab (2003) já verificara que as crianças de São Paulo apresentaram relações conflituosas predominantemente com os pares do mesmo sexo. Laursen e Hartup (1989), estudando conflitos em crianças de três a quatro anos de idade, encontraram que $30 \%$ dos conflitos ocorreram entre pares de meninos, $36 \%$ entre pares de meninas e $34 \%$ entre díades mistas. Se totalizarmos nossos dados, verificamos que eles foram semelhantes aos obtidos por esses autores. Murphy e Eisenberg (1996), estudando crianças de oito e nove anos de idade, constataram que elas relatavam sentir mais raiva de companheiros do mesmo sexo do que daqueles de sexo oposto. As mesmas autoras, em estudo posterior, confirmam esse dado (Murphy \& Eisenberg, 2002). A predominância de disputas com pares do mesmo sexo parece, portanto, um fato bastante generalizado entre as crianças pesquisadas em diversos estudos. Embora a maioria deles não tenha se preocupado em comparar interações conflituosas com o total de interações, os dados apresentados por Bussab, em relação a estas mesmas crianças paulistanas, denotam que há forte correlação entre interações amistosas e conflituosas - o que nos leva a supor que as crianças conflitam mais com companheiros do mesmo sexo, porque interagem mais com eles. 


\subsubsection{Sexo do parceiro e componentes de conflitos}

Vários autores referem-se ao fato de haver diferenças na reação das crianças durante o conflito em função do sexo do parceiro (Laursen \& Hartup, 1989; Murphy \& Rosenberg, 1996, 2000). Com a finalidade de investigar a influência dessa variável, efetuamos análises de regressão pelo método stepwise para verificar quais seriam os componentes dos conflitos preditivos do tipo de parceria: em primeiro lugar, tomando como variável independente a freqüência de conflitos com parceiros de mesmo sexo (Tabela 8.3) e, em segundo, o número de desavenças com parceiros do sexo oposto (Tabela 8.4). Em outras palavras, procuramos averiguar quais foram os tipos de elos preditivos da freqüência de conflitos com crianças do mesmo sexo e do sexo oposto.

Percebe-se, pelos dados da Tabela 8.3, maior número de associações positivas entre componentes do conflito e parceria com crianças do mesmo sexo no grupo de São Paulo. Entre as crianças de Ubatuba, praticamente não se encontraram componentes preditivos de conflitos com o mesmo sexo - o que pode ser entendido como menor consistência e maior variabilidade nas reações das crianças ubatubanas. Entre os meninos de São Paulo, foram componentes de conflitos preditivos de parceria com pares do mesmo sexo: quanto ao motivo, disputa por objetos, brincadeira que excedeu limites e ameaça, provocação ou agressão injustificadas; quanto às estratégias de oposição, ameaça de agressão física; quanto às reações à oposição, insistir, tirar o objeto, fazer chantagem e contrapor-se verbalmente através de negativa simples; quanto aos desenlaces, os desfechos coercitivos. Entre as meninas paulistanas, observaram-se as seguintes estratégias preditivas de conflitos com parceiras do mesmo sexo: quanto ao motivo, disputa por objetos e brinquedos; quanto às estratégias de oposição, negação simples, agressão ou provocação verbal e imposição verbal; quanto às reações à oposição, contraposição ou negação verbal simples; e, quanto ao desenlace, neutralização do conflito. Entre as crianças ubatubanas, verificou-se como componente preditivo de conflitos com parceiros do mesmo sexo apenas tirar ou tentar tirar o objeto, como estratégia de oposição entre as meninas e como reação à oposição entre os meninos. 
Tabela 8.3. Componentes de conflito (motivos, estratégias de oposição, reação à oposição e desenlaces) positivamente preditivos de conflitos com parceiros do mesmo sexo.

\begin{tabular}{|c|c|c|c|}
\hline $\begin{array}{l}\text { Compone } \\
\text { n-tes }\end{array}$ & $\begin{array}{l}\text { Gênero/or } \\
\text { igem }\end{array}$ & Componentes preditivos & $F$ \\
\hline \multirow[t]{4}{*}{ Motivos } & Meninos & Disputa por objetos, brincadeira excede & \multirow{2}{*}{$\begin{array}{l}\mathrm{F}_{1,8}=51,945 \\
* * *\end{array}$} \\
\hline & SP & $\begin{array}{l}\text { limites, ameaça, provocação ou agressão } \\
\text { injustificada }\end{array}$ & \\
\hline & Meninas & Disputa por objetos & $\mathrm{F}_{1,8}$ \\
\hline & SP & & $38,257 * * *$ \\
\hline \multirow{6}{*}{$\begin{array}{l}\text { Estratégia } \\
\text { s de } \\
\text { oposição }\end{array}$} & Meninos & Ameaça de agressão física & $\mathrm{F}_{1,8}$ \\
\hline & SP & & $23,486 * *$ \\
\hline & Meninas & Negação simples, agressão ou provocação & $\mathrm{F}_{1,8}$ \\
\hline & $\mathrm{SP}$ & verbal, imposição verbal & $35,420 * * *$ \\
\hline & Meninas & Tira ou tenta tirar objeto & $\mathrm{F}_{1,8}$ \\
\hline & Ubatuba & & $16,129 * *$ \\
\hline Respostas & Meninos & Insiste, tira objeto, chantagem, negação & $\mathrm{F}_{1,8}$ \\
\hline & SP & simples & $263,393 * * *$ \\
\hline \multirow[t]{2}{*}{ oposição } & $\begin{array}{l}\text { Meninas } \\
\text { SP }\end{array}$ & Contraposição verbal simples & $\begin{array}{l}\mathrm{F}_{1,8} \\
26,463 * *\end{array}$ \\
\hline & $\begin{array}{l}\text { Meninos } \\
\text { Ubatuba }\end{array}$ & Tira objeto & $\begin{array}{l}\mathrm{F}_{1,7} \\
12,600 * *\end{array}$ \\
\hline \multirow{3}{*}{$\begin{array}{l}\text { Desenlac } \\
\mathrm{e}\end{array}$} & Meninos & Desfecho coercitivo & $\mathrm{F}_{1,8}=7,610^{*}$ \\
\hline & $\mathrm{SP}$ & & \\
\hline & $\begin{array}{l}\text { Meninas } \\
\text { SP }\end{array}$ & Neutralização & $\begin{array}{l}\mathrm{F}_{1,8} \\
12,464 * *\end{array}$ \\
\hline
\end{tabular}

Em relação a conflitos com crianças do mesmo sexo, a diferença entre os grupos de São Paulo e de Ubatuba foi notável, assim como foi acentuada a diferença entre os gêneros nos componentes de conflitos associados a esse tipo de parceria. Murphy e Eisenberg (1996) relatam que conflitos mais duros e agressivos ocorreram em meninos e com parceiros do mesmo sexo. Laursen e Hartup (1989) verificaram que, nos conflitos entre parceiros de mesmo sexo, meninos mostraram uma freqüência maior de agressão física do que as meninas e que, quanto à agressão verbal, não houve claras diferenças entre os dois gêneros. Embora muitas das relações estabelecidas retratem o estilo interacional e os modos de lidar com conflitos de meninos e de meninas, constata-se que as diferenças de gênero foram muito claras em São Paulo, em se tratando de conflitos com parceiros de mesmo sexo: meninas revelaram comportamentos mais construtivos e pró-sociais, enquanto os meninos reagiram de forma mais truculenta, muito embora haja também uma sobreposição entre os gêneros, conforme observaram, em seus estudos, Hawley (2002) e Murphy e Eisenberg (1996), entre outros autores. 
Tabela 8.4. Componentes de conflito (motivos, estratégias de oposição, reação à oposição e desenlaces) positivamente preditivos de conflitos com parceiros do sexo oposto.

\begin{tabular}{lllc}
\hline Componentes & $\begin{array}{l}\text { Gênero/orig } \\
\text { em }\end{array}$ & Componentes preditivos & $F$ \\
\hline Motivos & Meninos SP & Motivo ignorado & $\mathrm{F}_{1,8}=$ \\
& & & $22,078^{* *}$ \\
& Meninos & Disputa de objetos & $\mathrm{F}_{1,7}=$ \\
& praia & & $6,689^{*}$ \\
Estratégias de & Meninos SP & Agressão e provocação verbal & $\mathrm{F}_{1,8}=$ \\
oposição & & & $22,533^{* *}$ \\
Respostas à oposição & Meninos SP & Movimento de retenção não & $\mathrm{F}_{1,8}=$ \\
& & agressivo & $22,533^{* *}$ \\
Desenlace & \multirow{2}{*}{ Meninos SP } & Desfecho coercitivo & $\mathrm{F}_{1,8}=$ \\
& & & $11,890^{* *}$ \\
\hline
\end{tabular}

$* \mathrm{p}<0,05 ; * * \mathrm{p}<0,01$

No que diz respeito a conflitos com companheiros do sexo oposto, quando comparados com aqueles com pares do mesmo sexo, observa-se, pela Tabela 8.4, que houve um número menor de componentes preditivos, sendo que a maior parte deles, confirmando dados de literatura (Maccoby, 1996; Murphy \& Eisenberg, 1996), foram menos hostis e contundentes. A única exceção foi o fato de os meninos paulistanos terem usado desenlaces coercitivos com parceiros de ambos os sexos. Em parte, concordam com esse resultado os dados de Miller et al.(1986), que verificaram que meninos usaram as mesmas táticas pesadas com ambos os sexos, enquanto as meninas somente as empregaram com meninos. Com referência a esse último dado, não há, para as meninas de nossos grupos, confirmação de relações estatisticamente significativas entre componentes de conflitos e parceria com meninos, o que indica que houve grande variedade nas respostas das meninas quando o oponente era do sexo masculino.

\subsection{Tamanho do grupo e conflitos}

O grande número de pesquisas e interpretações que relaciona tamanho e composição do grupo aos objetivos, emoções e estratégias envolvidas nos conflitos motivou-nos a procurar paralelos entre os dados obtidos neste estudo e aqueles relatados na literatura (Benenson et al., 2001; Fabes et al., 2003). 
Diversos autores constataram relações positivas entre tamanho do grupo e conflitos, sugerindo que os meninos exibiriam um número maior de conflitos por participarem mais de atividades em grupos grandes, que dariam maior margem a desentendimentos e disputas (Benenson et al., 2001; Fabes et al., 2003). Para se apurar se o mesmo aconteceu nos grupos que estudamos, embora a maior parte dos conflitos observados tenha-se dado diretamente entre duas crianças, procedeu-se à contagem do número de crianças em interação quando ocorreu o conflito e calculou-se a proporção de díades, tríades e políades em relação ao total de conflitos. A MANOVA 2 X 2 calculada para testar efeito de grupo cultural e de gênero sobre o tamanho do grupo em que ocorreram os conflitos não revelou efeito significativo de nenhuma variável. No entanto, observam-se, pela Figura 8.17, tendências muito semelhantes às encontradas em relação aos diversos tamanhos de grupo de brincadeira (Figura 3.1). Prevaleceram políades entre os meninos de São Paulo e entre as meninas de Ubatuba. Entre os meninos de Ubatuba, prevaleceram díades e políades e, entre as meninas de São Paulo, houve equilíbrio entre os diversos tamanhos de grupo.

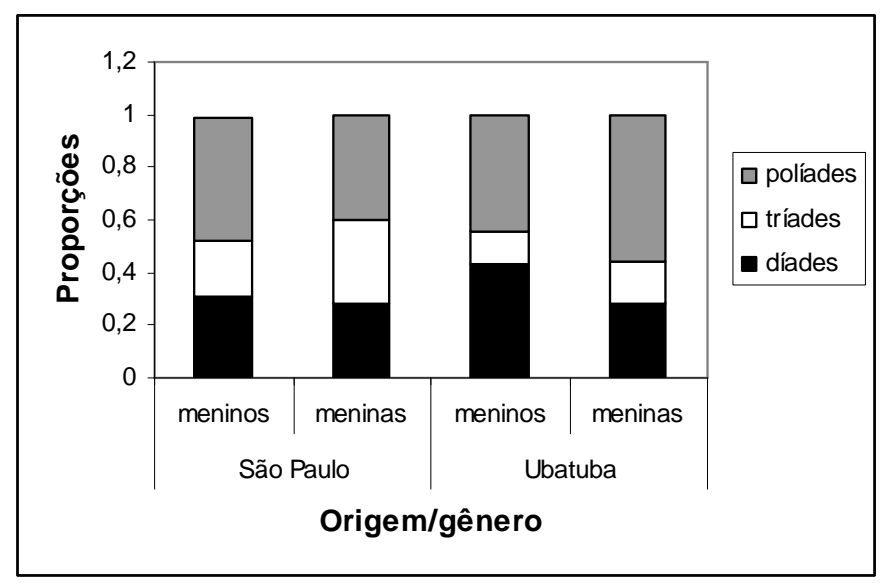

Figura 8.17. Proporções de conflitos em díades, tríades e políades.

Testes $\mathrm{t}$ pareados calculados para comparar os diversos tamanhos de grupo em que ocorreram conflitos mostraram os seguintes resultados significativos: entre os meninos de São Paulo, políades foram mais freqüentes do que díades $\left(t_{9}=2,203, p<0,05\right)$ e do que tríades $\left(t_{9}=\right.$ 3,607, p<0,01); entre as meninas de São Paulo, não houve diferenças significativas; políades foram mais freqüentes do que tríades entre meninos $\left(t_{8}=2,659, \mathrm{p}<0,05\right)$ e meninas $\left(t_{9}=3,259\right.$, $\mathrm{p}<0,01)$ de Ubatuba. Para verificar se havia diferenças significativas entre tamanhos de grupo de 
brincadeira e de conflito, dividimos cada tamanho de grupo de brincadeira de que participou o sujeito focal pelo total de participação em grupos de brincadeira e repetimos a operação para os grupos de conflito, obtendo índices relativizados. Testes $\mathrm{t}$ pareados entre esses índices, comparando tamanhos de grupo de brincadeira e de conflito, não revelaram resultados estatisticamente significativos, indicando que não houve diferenças entre as freqüências de ocorrência dos diferentes tamanhos de grupos em situação de conflito e de brincadeira. Portanto, embora, de maneira geral, a freqüência de conflitos em políades tenha-se mostrado mais alta do que em tríades, como as distribuições de tempo gasto brincando e da incidência de conflitos nos diversos tamanhos de grupo foram semelhantes, não temos elementos para afirmar que tenha havido maior probabilidade de ocorrer conflitos em grupos grandes.

Conforme já salientamos em relação aos grupos de brincadeira, Benenson et al. (2001) supõem que grupos maiores propiciem certo grau de anonimato que facilitaria a incidência de conflitos. Maccoby (1988) sugeriu que os homens adeririam mais abertamente do que as mulheres a comportamento competitivo, porque os grupos grandes, quando comparados às díades, dariam maior margem a conflitos. Benenson et al. verificaram que o comportamento competitivo era maior em grupos de quatro elementos do que em díades, apenas para crianças do sexo masculino. Os dados do trabalho desses últimos autores são mais coerentes com os que encontramos, uma vez que não se constataram diferenças de tamanhos de grupo em que ocorreram conflitos entre as meninas de São Paulo, e que, como já vimos comentando, as meninas de Ubatuba, em muitos aspectos, mostraram características de menor estereotipia sexual e, portanto, comportamentos mais semelhantes aos dos meninos.

Embora os métodos usados nos diversos trabalhos que investigaram a relação entre tamanho do grupo e conflitos sejam diferentes, é importante ressaltar que muitos dos autores citados - que encontraram maior freqüência de conflitos em grupos grandes do que em díades não se preocuparam em comparar a incidência desses comportamentos com o total de interações. Uma vez que é provável que haja mais conflitos nos grupos em que há maior número de interações, deixar de comparar a incidência de conflitos com as interações em outros contextos pode acarretar conclusões precipitadas e errôneas. Esse é mais um argumento que fortalece a necessidade de se incluírem outros contextos, como o lúdico, para a análise dos conflitos numa perspectiva adequada. 


\subsection{Considerações finais}

Assim como nos grupos de brincadeira, encontramos semelhanças e diferenças acentuadas na freqüência e distribuição dos componentes dos conflitos nos dois grupos culturais e gêneros. Enquanto as reações de meninas e meninos paulistanos aproximaram-se mais de achados dos trabalhos com crianças euro-americanas, o comportamento das crianças ubatubanas divergiu, em alguns aspectos, do esperado, mediante esses achados.

O número de elos ou unidades de conflito foi menor entre as crianças de Ubatuba, indicando que seus desentendimentos eram resolvidos mais simples e rapidamente. Enquanto houve em São Paulo episódios de conflito que duraram todo o tempo de observação (cinco minutos), em Ubatuba, as situações conflituosas foram mais pontuais e diretas, assim como outras características, já comentadas, de comportamento destas crianças

Constatamos que, quando comparadas às ubatubanas, as crianças paulistanas exibiram maior diversidade de estratégias de oposição, denotando um estilo mais variado de respostas durante o conflito. O uso mais diversificado e de várias estratégias verbais por parte das crianças paulistanas, em especial das meninas, coaduna-se com o que já constatamos a respeito das brincadeiras. O grupo de crianças paulistanas revelou comportamentos compatíveis com uma cultura que favorece o uso de estratégias verbais e o desenvolvimento do raciocínio lógicoabstrato, mais necessários, em tese, para um adequado desempenho em uma sociedade erguida sobre bases mais complexas. Em contraposição, as crianças de Ubatuba revelaram táticas mais diretas e menos diversificadas de enfrentamento - o que pode ser suficiente e mais apropriado para comunidades em que prevalece um estilo mais simples de comunicação. Da mesma forma, os ubatubanos usaram mais expedientes físicos e de contato corporal do que os paulistanos, os quais também utilizaram muitas estratégias de contato distal durante os conflitos. Esses resultados são compatíveis com uma maneira de criação mais proximal a que provavelmente as crianças de Ubatuba foram submetidas, em contraste com um modo de criação mais distal por que passaram as paulistanas.

As crianças paulistanas, em especial as meninas, apresentaram um número maior de respostas consideradas socialmente mais construtivas. Se, como estratégias de oposição e reações à oposição, as crianças de Ubatuba utilizaram expedientes considerados menos construtivos, ao final, no desenlace do conflito, apresentaram resultados bastante semelhantes aos das crianças paulistanas, denotando preocupação em terminar os conflitos de forma que não se inviabilizasse a continuidade da relação. 
Cabe aqui determo-nos rapidamente no conceito de construtividade das respostas sociais. A maior parte das considerações a que temos acesso a respeito da questão de comportamentos pró-sociais e "socialmente construtivos" referencia-se nas culturas ocidentais. Uma cultura que preconiza valores de independência, competitividade e excelência e que enfatiza o pensamento lógico-abstrato deve, provavelmente, avaliar a noção de construtividade social de maneira diversa daquela de culturas que se erguem sobre valores de cooperação, interdependência e que destacam o desenvolvimento do raciocínio prático. É inegável que as relações sociais se estabelecem sobre bases semelhantes em todos os grupos, sendo, em todos eles, necessária a continuidade de relações de cooperação e a preservação de vínculos interpessoais. No entanto, em sociedades mais ameaçadas pela desigualdade e pela distribuição diferencial de poder - em que a verticalidade predomina sobre a horizontalidade das relações -, é provável que a possibilidade de perturbação da ordem social e a ameaça à harmonia das relações estejam mais presentes. Em contraposição, em certas configurações de sociedades mais tradicionais e fundadas na preocupação com questões mais concretas, pode-se supor que a provável segurança, propiciada pela maior estabilidade de atitudes e valores, tornaria menos ameaçadoras as tentativas de ruptura e as manifestações de hostilidade e de agressividade entre seus membros. Essas ponderações levam-nos a pensar que, nessas sociedades, a noção de construtividade nas relações sociais seria menos central e menos preocupante, uma vez que haveria outros mecanismos de garantia para a continuidade das relações e dos vínculos, como normas de convivência mais estabelecidas e bem delimitadas: regras de vizinhança, de parentesco, etc. Por sua vez, nas sociedades em que as regras são mais mutáveis e complexas, garantir relações sociais harmoniosas e construtivas é algo que exige maior adaptabilidade de seus membros para os necessários ajustes e regulações interacionais.

Assim como nos grupos de brincadeira, as relações interpessoais se configuram de tal modo que, também através do conflito, manifesta-se uma cultura própria do grupo. Por essa razão, é temerário generalizar os dados e, como afirmam Laursen et al. (1996), simplificar em demasia as explicações para os conflitos.

Nos grupos de Ubatuba, pareceu mais lícito e possível usar táticas pesadas e diretas (Figura 8.18), tanto para meninos quanto para meninas, não obstante essas as tenham usado em menor grau. Já em São Paulo, a maior frequiência de exibição de agressão física dos meninos, quando comparados com suas colegas, acompanhou a tendência típica de gênero revelada pelas crianças euro-americanas. Se, na brincadeira, as estereotipias de gênero mostraram-se menos acentuadas entre os meninos de São Paulo, nos conflitos, eles parecem ter revelado um 
comportamento mais prototipicamente masculino. Em outras palavras, entre os garotos paulistanos, parece que o lado mais educado e polido que se configurou nas relações durante as brincadeiras não se manifestou da mesma forma quando estão implicadas emoções consideradas negativas, como as de raiva, tristeza e frustração, envolvidas nos conflitos. Embora essa seja uma hipótese de difícil comprovação, parece-nos que o "verniz" cultural pode atingir certos comportamentos mais moduláveis e controláveis, como as prazerosas atividades lúdicas, enquanto as emoções consideradas mais negativas permanecem mais inatingíveis, menos domináveis e, portanto, menos afetadas pelo polimento cultural.

Uma interessante perspectiva para a análise das relações grupais nos é fornecida por Maccoby (1996). A autora argumenta que certas crianças encontram satisfação em realizar determinadas atividades em grupo, independentemente das relações de amizade que mantenham entre si. Mantêm-se juntas, simplesmente porque todas apreciam determinadas atividades coletivas e formam uma configuração grupal semelhante à de um time bem ajustado, que permite que nelas encontrem prazer. Nesse caso, diferentemente da situação diádica, é o grupo que provê a ligação, não sendo necessárias relações de amizade íntimas entre as crianças que o compõem.

A composição de subgrupos dentro do grupo de brincadeira decorre do fato de as crianças se organizarem em grupos que lhes permitem obter satisfação em atividades coletivas. Os subgrupos que convivem diariamente acabam, também, formando uma microcultura própria, podendo manter com outros subgrupos uma relação de subordinação, de complementaridade, de colaboração, de oposição, de competição ou, mais provavelmente, relações que envolvem, em maior ou menor grau, todos esses elementos. Da dinâmica das relações dos indivíduos entre si e dos indivíduos como membros de um grupo e dos subgrupos entre si resulta a configuração relacional do grupo como um todo, com todas as suas contradições, polarizações, convergências e divergências. Nunca, portanto, a configuração grupal será uma situação estática e um determinado recorte dessas relações será sempre um retrato parcial de um momento desse grupo em constante movimento. Isso posto, fica claro que, embora haja processos em comum, é necessário ter muito cautela com generalizações a partir de um determinado funcionamento grupal. As conclusões que tiramos restringem-se, portanto, a determinados grupos num dado momento de sua história.

Tendo em mente essas características dos dados relacionais, que, por sua vez, também fazem parte da universalidade do fenômeno do conflito, posto que é situacional e deve ser contextualizado, os resultados deste estudo remetem-nos igualmente a pensar em diversos 
aspectos que podem ser considerados mais gerais na dinâmica dos conflitos. Há, sem dúvida, com afirma Hawley (2002), variações individuais na motivação para perseguir recursos. Como tratamos nossos dados com base em médias grupais, esse fenômeno pode ter fugido de nosso olhar. Reconhecemos, contudo, que, em ambos os grupos e gêneros, houve crianças que exerceram mais disputas por recursos, seja pela posse de objetos, seja por atenção, posição, autoridade ou controle social.

Da mesma forma que se perceberam variações individuais para perseguir recursos, constataram-se estilos pessoais de resolver disputas: houve crianças conciliadoras, crianças que impunham suas opiniões, crianças que enfrentavam outras, crianças que evitavam situações conflitivas, crianças que gostavam de provocar reações nas outras e crianças que se isolavam. Encontramos esses diversos tipos de crianças nos dois grupos culturais e gêneros.

Observamos que, em meninas e meninos dos dois grupos culturais, as provocações ensejaram mais reações com conseqüências positivas e afiliativas do que negativas e perturbadoras para as relações grupais. Constatamos equivalência de número de conflitos nos dois grupos culturais e gêneros. Verificamos, entre meninos e meninas de ambos os grupos, os seguintes fatos comuns em relação aos componentes dos conflitos: o motivo mais freqüente de disputas foi pela posse de brinquedos e de objetos; as estratégias mais comuns de expor oposição foram coercitivas, manifestas principalmente por tirar o objeto do outro ou por ameaçá-lo ou agredi-lo; reações à oposição muito freqüentes foram ceder ao desejo do outro ou fazer uma contraposição verbal simples; a maior parte dos conflitos ocorreu com crianças do mesmo sexo; a maior parte dos desenlaces foi afiliativa ou por neutralização do conflito, indicando a importância da continuidade das relações interpessoais para estas crianças.

Todas essas constatações remetem-nos a ressaltar a importância de estudos interculturais para a compreensão dos fenômenos psicossociais, dentre os quais merecem destaque os conflitos, tendo em vista sua universalidade, complexidade e caráter estritamente relacional. Numa espécie como a humana, em que o ajustamento mútuo é necessário para a convivência em grupo, é imprescindível investigar os processos suprapsicológicos que regem a vida social (Bussab, 2003; Carvalho \& Rubiano, 2004). Dentro dessa perspectiva, estudos da ontogênese de comportamentos reguladores das relações interpessoais e de suas conjunções com fenômenos culturais são essenciais e particularmente elucidativos. Na ausência de dados comparativos interculturais, corre-se o risco do grande equívoco de se tomar como geral um fenômeno que é particular de determinadas culturas. 


\section{CONCLUSÕES}

O conjunto de dados obtidos neste estudo nos leva a pensar em quão relativa é a regularidade de alguns achados de trabalhos na área da psicologia do desenvolvimento, que se pautaram apenas em crianças dos países europeus e norte-americanos, principalmente no que diz respeito a questões de gênero, em que este trabalho evidenciou resultados peculiares em muitos aspectos. A grande maioria dos estudos com crianças euro-americanas encontrou diferenças de gênero nas seguintes categorias: meninos tendem a ser mais ativos, a movimentar-se em espaços mais amplos, a preferir brincar em grupos grandes, a apresentar mais conflitos, a ser mais agressivos, menos preocupados com as relações interpessoais e menos negociadores no encaminhamento das disputas; as meninas, por sua vez, mostram-se mais contidas e organizadas em suas brincadeiras, preferem brincar em espaços menores, têm predileção pelas relações diádicas, conflitam menos, tendem a encaminhar os conflitos usando estratégias mais afiliativas, preocupadas que são com a continuidade da relação e com os sentimentos dos outros.

Alguns dados do presente trabalho confirmam esses achados, mas outros mostram diferenças que podem ser devidas, tanto a idiossincrasias dos grupos estudados quanto a peculiaridades advindas de influências culturais mais amplas a que estavam sujeitas as crianças observadas. As principais diferenças constatadas na comparação com estudos europeus e americanos foram constatadas no grupo de crianças de Ubatuba. Entretanto encontramos, também, algumas tendências no grupo de São Paulo que diferiram dos dados de outros países. O subgrupo que mais se conformou com os dados apresentados pelos estudos internacionais foi o das meninas paulistanas, que preferiram brincar em grupos do mesmo sexo e em díades e tenderam a encaminhar os conflitos de forma mais afiliativa do que seus colegas. Em relação aos conflitos, os meninos paulistanos também apresentaram comportamentos semelhantes aos constatados em crianças euro-americanas, usando estratégias mais coercitivas no encaminhamento e desenlace dos conflitos. Os dados mais discrepantes dos meninos de São Paulo, quando comparados aos de estudos de outros países, e que apontam na direção de uma menor estereotipia de papéis de gênero, foram os relativos a sua participação em brincadeiras. Nesse aspecto, os meninos paulistanos revelaram comportamentos semelhantes ao das meninas, 
quanto à freqüência de participação em díades e nas diversas modalidades de brincadeiras - com exceção das brincadeiras de contingência social, modalidade em que se comportaram na direção esperada em vista de dados de outras culturas, participando mais de brincadeiras turbulentas proximais do que suas colegas.

Meninas e meninos de Ubatuba, por sua vez, comportaram-se, em muitos aspectos, de maneira diversa daquela que seria de se esperar a partir de resultados encontrados em estudos internacionais, principalmente no tocante ao tipo de interação nas brincadeiras e nos conflitos. As meninas brincaram mais em grupos grandes do que seus companheiros ubatubanos e do que as meninas paulistanas. Envolveram-se num número de disputas equivalente ao de seus colegas do sexo masculino e manifestaram encaminhamentos mais impositivos e agressivos durante os conflitos do que as meninas paulistanas. Evidentemente, a partir de observações de um número tão pequeno de crianças, não se pode concluir se essas constatações se aplicariam também a outros grupos de crianças ubatubanas. Entretanto, neste grupo em particular, as meninas caiçaras exibiram um comportamento ativo e belicoso - bastante semelhante ao dos meninos paulistanos e ao de seus colegas ubatubanos.

No que diz respeito às diferenças culturais mais marcantes, encontramos, quanto ao tipo de atividades lúdicas, uma distribuição mais uniforme das diversas modalidades de brincadeira no grupo de Ubatuba e uma notável predominância de brincadeiras de faz-de-conta entre as crianças paulistanas. Em contrapartida, as crianças ubatubanas, principalmente os meninos, envolveram-se muito mais em jogos de regras e em brincadeiras de contingência social - os meninos, nas turbulentas e as meninas, nas não turbulentas -, com predomínio das proximais, envolvendo contato físico. Em relação às provocações, também predominaram as do tipo verbal em São Paulo e não verbal em Ubatuba. Quanto aos conflitos, percebeu-se menor diversidade de motivos e estratégias e o uso de mais táticas físicas, diretas e pesadas no grupo ubatubano. Nas crianças de São Paulo, encontramos, além de maior diversidade tática, um número maior de elos nos conflitos e o uso de estratégias verbais mais sutis e indiretas em seu encaminhamento.

No entanto, é provável que as semelhanças entre os grupos tenham sido maiores do que as diferenças. O tempo dedicado à brincadeira durante as atividades livres na pré-escola foi semelhante nos dois grupos culturais e gêneros. Em ambos, houve predomínio das brincadeiras interativas. Embora a distribuição das diferentes modalidades de brincadeira no tempo tenha sido diferente nos dois grupos culturais, se nos detivermos na forma de cada uma delas, encontramos semelhanças notáveis. As crianças dos dois grupos culturais apresentaram freqüência equivalente de conflitos, maior número de conflitos motivados por disputa de objetos 
e de desenlaces que permitissem a continuidade da relação e mais desavenças com crianças do mesmo sexo. Embora os conflitos em Ubatuba tenham sido mais curtos, os diversos tipos de motivos, estratégias de oposição, reações à oposição e desenlaces estiveram presentes nos dois grupos.

Todas as diferenças e semelhanças apontadas constituem, por si sós, evidências da importância dos estudos interculturais para a compreensão dos universais do desenvolvimento infantil e das influências ambientais e socioculturais sobre o comportamento.

Muitas das diferenças assinaladas estão provavelmente relacionadas com a cultura local em que se inseriam os grupos de brincadeira estudados. Como vimos comentando durante todo o trabalho, as crianças paulistanas exibiram comportamentos compatíveis com aqueles encontrados em sociedades urbanas de grande porte, que envolvem maior diversidade de papéis e requerem de seus membros maior modulação e adaptabilidade do comportamento a constantes mudanças. Meninos paulistanos mostraram menor estereotipia de gênero durante as brincadeiras, revelando adaptação a um estilo de criação que preconiza a igualdade de direitos e deveres entre os sexos. Em comparação com os ubatubanos, os meninos e as meninas paulistanas participaram mais de brincadeiras de faz-de-conta e exibiram nelas maior diversidade de temas e papéis - dado também compatível com uma sociedade fundada em bases mais complexas. Ressaltamos, contudo, que as diferenças entre os gêneros reveladas pelas crianças de São Paulo ainda denotam a presença de alguns valores mais conservadores: meninos se mostraram mais agressivos e impositivos no encaminhamento dos conflitos, participaram mais de brincadeiras turbulentas, de temas fantásticos, como havíamos constatado anteriormente num grupo urbano da mesma cidade (Morais, 1980), e as meninas participaram mais de brincadeiras que envolviam atividades diárias e cuidados com os outros e mostraram- se mais preocupadas com as relações interpessoais.

No grupo de crianças paulistanas, constatou-se maior diversidade de estratégias no enfretamento de conflitos e um predomínio de uso de verbalizações durante as disputas, o que é compatível com uma sociedade que requer maior diversificação de papéis e enfatiza o desenvolvimento do raciocínio abstrato. Por sua vez, o uso de táticas mais diretas e simples por parte das crianças ubatubanas parece refletir uma sociedade com menor especialização de papéis e que requer uma aprendizagem rápida (Keller, 1998) e soluções imediatas para problemas práticos.

Cabe, neste ponto, um pequeno parêntese para pontuar algumas diferenças nas condições de vida observadas nas duas comunidades, além das já citadas no segundo capítulo 
deste trabalho. Em São Paulo, as crianças chegam de carro ou de ônibus, acompanhadas do pai ou da mãe, que iniciarão seu trabalho diário na Universidade. No caminho, terão cruzado com dezenas de rostos anônimos. Apesar das possíveis tensões passadas no trajeto de casa para a creche, com a lentidão do trânsito e o transporte coletivo precário, essas crianças estarão bem protegidas durante o seu dia na instituição. Serão cuidadas, alimentadas, descansarão, brincarão, serão estimuladas e aprenderão. Terão de abrir mão de sua privacidade e de alguns confortos da casa - o que algumas crianças declararam informalmente ser muito perturbador -, mas serão cuidadas por adultos e terão companheiros em suas atividades. A creche é totalmente cercada por muros e as portas que dão para a rua permanecem trancadas por questões de segurança. $\mathrm{O}$ tempo psicológico em São Paulo é acelerado. Sob o mote "tempo é dinheiro", todos correm para não se atrasar ou têm a sensação de que estão sempre atrasados - o que imprime à criança uma necessidade de ser rápida, de acelerar o ritmo.

De outro lado, na Praia de Itamambuca, observamos um grupo de crianças que chega à escola a pé ou de bicicleta, muito eventualmente de carro. Não terão passado por um trajeto estressante, pois vivem num lugar sossegado, próximo à escola, com baixíssima densidade populacional. No caminho, as poucas pessoas que encontram têm fisionomias familiares e, mesmo as que não se conhecem, costumam se cumprimentar. O ritmo de vida é lento, espaçado. Não há pressa, há tempo para tudo - e tudo são principalmente as coisas simples da vida: alimentar-se, brincar ou trabalhar, descansar, dormir, passear, visitar os amigos, ir à igreja e, eventualmente, a alguma reunião na comunidade. A escola é praticamente aberta: na face dianteira, é rodeada por uma cerca de estacas; o portão nunca é trancado e não há porta de entrada; passando o portão de acesso, encontra-se o pátio, onde as crianças brincam nas atividades livres. Nos fundos, um frágil portão e um alambrado baixo dividem a área da escola do campo de futebol, que é aberto para a rua e faz fronteira com a mata. Mesmo assim, ninguém entra nem sai sem autorização, pois os limites simbólicos da escola são respeitados.

O contraste entre o espaço aberto da escola de Ubatuba e o ambiente totalmente cercado da escola de São Paulo remete-nos ao tratamento dado à questão de limites nas duas comunidades. Na creche paulistana, até para proteger as crianças e os funcionários, o limite é externo e imposto. Em Ubatuba, espera-se que as crianças entendam suas restrições, porém através de limites que foram internalizados; professores e funcionários também não temem que o prédio seja invadido por estranhos. O trabalho de Gosso et al. (no prelo), que pesquisaram o modo de vida e as brincadeiras em diversas sociedades indígenas, traz inúmeros exemplos de comunidades indígenas que se pautam numa educação voltada para o bem estar coletivo e nas 
quais as crianças aprendem seus limites sem severas restrições nem punições. Não estamos afirmando que os pais ubatubanos conservem este tipo de educação, tão consagrado entre vários grupos de caçadores-coletores, mas as possibilidades que experimentam as crianças ubatubanas de circularem livremente nos arredores de sua moradia, de brincarem na praia, no mar, nos rios, nas cachoeiras e na mata certamente lhes trazem uma experiência de vida, de liberdade e de limites bem diferente daquela das crianças de São Paulo, que passam grande parte de seu tempo dentro dos muros de suas casas, condomínios e escolas.

Outro aspecto que merece ser comentado em relação aos diferentes contextos de criação das crianças dos dois grupos culturais é o da independência em relação aos adultos, que ocorre muito mais precocemente nas crianças ubatubanas, quando comparadas às paulistanas. A partir dos seis ou sete anos de idade, as crianças da praia já vão sozinhas para a escola. Demonstra sua independência o grande número de bicicletas estacionadas no pátio frontal da escola. Observamse, freqüentemente, irmãos mais velhos, de cerca de onze ou doze anos de idade, trazendo os mais novos nas garupas de suas bicicletas - diferentemente do que se constata entre crianças paulistanas, que chegam à escola sempre acompanhadas de adultos. Nas brincadeiras de faz-deconta, enquanto as meninas paulistanas andam de carro, vão ao cabeleireiro e levam crianças para a escola, para aulas de balé ou para um shopping, as ubatubanas revelam que já fazem pequenas compras para suas mães em mercearias ou mercadinhos, provavelmente próximos de suas casas. Já mostram que sabem manusear rodos e vassouras com relativa habilidade. Esses comportamentos indicam que a experiência de liberdade e de responsabilidade começa mais cedo para as crianças de Ubatuba. Assim é também em inúmeras sociedades indígenas (Gosso et $a l$, no prelo), em que a criança se torna independente ainda numa idade mais precoce do que a observada em Ubatuba. Evidentemente, essas experiências resultam em diferentes conotações do senso de dever em relação a si mesmas e ao próximo - fato que acaba por repercutir no desenvolvimento psicossocial das crianças e na própria cultura, gerando, por exemplo, responsabilidades em relação ao trabalho e compromissos conjugais e de paternidade e de maternidade em idades mais precoces.

Como as crianças de Ubatuba vivem, desde cedo, mais livres e mais expostas a um ambiente natural atrativo e cheio de riscos, pode parecer a quem está acostumado com a conduta de crianças de cidade grande que as ubatubanas assumem, quando comparadas às paulistanas, comportamentos muito mais ousados e arriscados, como subir em árvores e troncos altos e deles saltar diretamente para o chão, entrar sem medo na mata, nos rios e no mar, carregar materiais pesados e pontiagudos, entre outros. Entretanto as crianças de ambos os grupos culturais 
exibiram comportamentos que desafiavam limites, testando suas habilidades físicas. Como já relatamos, as crianças paulistanas também punham constantemente à prova suas possibilidades, subindo, descendo, pendurando-se, colocando-se de cabeça para baixo, balançando-se com força e em posições arriscadas nos equipamentos do playground. Do mesmo modo, foram freqüentes, nos dois grupos culturais, os desafios sociais - neste trabalho classificados como brincadeiras turbulentas ou como provações ou conflitos -, tais como amarrar fortemente colegas numa estaca, empurrá-los, arrastá-los pelo chão, fazê-los tropeçar, abafá-los e fazê-los girarem em caixotes precários. Faz parte dos universais do comportamento humano - e também de outros mamíferos - arriscar-se e desafiar seus limites na protegida situação da brincadeira. Dessa forma, organismos imaturos de várias espécies vão adquirindo e treinando habilidades, ao mesmo tempo em que testam o alcance de suas possibilidades.

Um interessante conceito, aplicável à explicação de nossos dados, é o de adaptação ao nicho ecocultural, proposto por Greenfield et al. (2003). Os autores afirmam que, do ponto de vista ecocultural, condições econômicas e ambientais criam estruturas sociais diferentes que favorecem diferentes caminhos de desenvolvimento - um que valoriza a interdependência e o senso coletivo entre as pessoas e outro que preconiza a independência pessoal e a individualidade -, que surgem como adaptações às condições de vida. Dessa forma, a via interdependente parece ser uma resposta adaptativa para pequenas comunidades que se baseiam numa economia de subsistência, valorizam a tradição e, que, portanto, mudam lentamente. A via independente, por sua vez, parece uma resposta adaptativa para as comunidades grandes, anônimas e urbanas, que valorizam a inovação e que, portanto, transformam-se mais rapidamente .

Segundo Greenfield et al. (2003), a inteligência tecnológica e científica é mais desenvolvida nas sociedades industriais e a cognição social, nas interdependentes. Os autores constatam que as culturas africanas nativas não só enfatizam a inteligência social, mas também encaram o papel de habilidades técnicas como meios para atingir fins sociais. A nosso ver, não só a inteligência social, mas também a prática é mais desenvolvida nas pequenas sociedades baseadas numa economia de subsistência. Montagu (1988), por exemplo, destaca a grande habilidade espacial e de raciocínio mecânico de alguns povos esquimós. O autor atribui o desenvolvimento dessas capacidades à forma de criar as crianças próximas ao corpo da mãe, que, em suas peregrinações, as carregam nas costas desde cedo, permitindo, assim, que experienciem muito precocemente as noções de grandes movimentos e de distância. Greenfield et al. também afirmam que, enquanto as sociedades européias e norte-americanas valorizam o 
amplo conhecimento dos fatos e o entendimento teórico e tecnológico, comunidades maias e africanas priorizam o conhecimento prático, semelhantemente ao que assistimos nas crianças paulistanas e ubatubanas, respectivamente.

Inúmeros elementos deste trabalho levam-nos a concluir que a cultura das crianças ubatubanas observadas era híbrida: nem preponderantemente de pequena escala, nem baseada na economia de subsistência - como era, provavelmente, há cinqüenta anos atrás, antes da chegada do turismo -, nem fundada na economia industrial e de serviços de larga escala e de alta tecnologia. Segundo Georgas (2003), por causa das mudanças econômicas, da televisão, do cinema, da educação, da Internet, do turismo e do comércio, as pequenas sociedades não são mais totalmente dependentes dos sistemas de subsistência. Com a expansão dos meios de comunicação, hábitos e valores das sociedades industrializadas vão se infiltrando gradativamente nas comunidades mais tradicionais.

À medida que a economia de subsistência vai sendo substituída pelo turismo e pelo comércio, conforme também constata Georgas (2003), os valores das sociedades tradicionais tendem a modificar-se. Observando o que acontece em pequenas sociedades, o autor alega que, contrariando a opinião de muitos sociólogos e antropólogos, a modernização não implica necessariamente a rejeição de valores tradicionais. As relações familiares são muito complexas para responder uniformemente a mudanças econômicas. Georgas, referindo-se a constantes observadas em diversas culturas, cita um estudo realizado em 16 países, dentre eles os Estados Unidos, a China e a Índia, que encontrou que, em todas as nações, as crianças relatavam ter maior vínculo emocional com a mãe; em segundo lugar, com os irmãos; e, em terceiro, com os pais. O autor conclui que existem evidências de que haja diferentes formas de estrutura e de função familiar, influenciadas pelo crescimento econômico, mas que as tradições culturais têm grande peso na conservação de costumes e valores.

Georgas (2003) constata, ainda, que, muito embora o número de famílias nucleares venha aumentando, muitas delas ainda mantêm estreitas relações com os familiares de parentesco estendido, como tios, primos e avós. Nas classes mais pobres principalmente, a renda das pessoas é tão baixa que as obriga a manter relações de dependência com os parentes. Em áreas urbanas, podem-se encontrar famílias estendidas, cujos membros moram perto uns dos outros, de tal forma que um pode ajudar o outro em caso de necessidade (Seidl de Moura, comunicação pessoal). Essa realidade pode ser verdadeira tanto para as crianças de São Paulo quanto para as de Ubatuba. Contudo, é provável que, numa comunidade pequena como a 
ubatubana, de baixo nível socioeconômico, membros da família estendida tenham maior contato entre si. Evidentemente, para que pudéssemos tirar conclusões a respeito do tipo de família e do nível de manutenção de tradições das crianças de ambos os grupos estudados, teríamos, também, de investigá-las. Essa é uma atraente proposta para futuros estudos.

Conquanto não tenhamos trabalhado com o conceito de nível socioeconômico, não podemos ignorar essa importante variável, nem menosprezar sua influência, nem deixar de tecer algumas considerações sobre sua relevância. Na dissertação de mestrado, trabalhamos com crianças paulistanas provenientes das classes A e B (Morais, 1980). Constatamos grandes diferenças entre meninos e meninas nesse grupo, no sentido do que vem sendo encontrado com crianças euro-americanas: os meninos eram mais ativos e agressivos e desempenhavam predominantemente temas fantásticos e aventurescos em suas brincadeiras simbólicas, enquanto as meninas se mostravam mais contidas, menos agressivas e desempenhavam, predominantemente, temas domésticos nas brincadeiras de faz-de-conta. Nesse grupo - liderado por um menino muito ativo e extremamente imaginativo, que incentivava os colegas a brincarem de inúmeros temas fantásticos, a maior parte deles inspirada nos super-heróis veiculados na mídia da época -, observamos, também, um subgrupo de meninos mais passivos e com maiores dificuldades de interação. Tal fato foi igualmente constatado em alguns meninos dos grupos culturais aqui estudados e diz respeito à aceitação por companheiros e a competência social - fenômenos que não foram explorados no presente estudo.

Mais recentemente, realizamos um estudo, que serviu de piloto para o presente trabalho, numa creche paulistana (Morais, 2000, não publicado), com sete crianças de nível socioeconômico baixo (quatro meninas e três meninos das classes D e E). Apesar do número pequeno de crianças, observamos duas meninas muito ativas, bem aceitas pelo grupo, que lideravam as brincadeiras. Entre os meninos, dois tinham dificuldades de interação, eram mais submissos e isolados e um, com grandes problemas familiares, era bastante agressivo, mas querido por alguns colegas e muito ativo e imaginativo. Nesse particular minigrupo, constatamos mais brincadeiras imaginativas com conteúdos domésticos, não havendo praticamente diferenças entre os sexos quanto aos temas das brincadeiras simbólicas, provavelmente porque a força de liderança das meninas nas atividades lúdicas era grande. Verificamos, ainda, que a freqüência de brincadeira interativa (83\%) foi semelhante à encontrada nos grupos observados no presente estudo. Embora o critério empregado para a classificação das brincadeiras tenha sido ligeiramente diferente do utilizado neste trabalho, constatou-se, em linhas gerais, que a distribuição das brincadeiras pelo tempo de observação 
situou-se num ponto intermediário entre as observadas nos grupos de Ubatuba e de São Paulo. As crianças do estudo de 2000 ocuparam 30\% de seu tempo de atividade livre brincando de fazde-conta, dedicaram $22 \%$ do tempo a brincadeiras de exercício físico e $10 \%$, a jogos de regras. Os dados dessa pequena amostra contribuem para levantar a possibilidade de que uma parte das diferenças encontradas entre o comportamento dos dois grupos no presente estudo deva-se ao nível socioeconômico das crianças que, evidentemente, está tão imbricado na cultura quanto outros aspectos levantados em relação aos ambientes e contextos de vida.

No presente estudo, entre as crianças paulistanas, filhas de funcionários da Universidade, havia também representantes de diversos níveis socioculturais. Apesar de serem, em sua maioria, crianças de classe média, era possível distinguir o comportamento dos filhos de pais com nível de escolaridade maior daquele de crianças pertencentes a famílias cujos pais pertenciam às classes trabalhadoras. Os resultados obtidos no grupo paulistano devem, portanto, ser considerados como concernentes a crianças de nível socioeconômico misto (Gosso et al., 2002 e 2003). Embora tal dado não tivesse sido mensurado, observamos que os meninos e meninas paulistanas pertencentes às classes mais baixas também tenderam a utilizar táticas mais pesadas e mais rudes nos conflitos e brincadeiras, semelhantemente ao que foi observado entre as crianças ubatubanas.

Com essas considerações, pretendemos salientar que é provável que parte do que foi constatado neste trabalho, em relação a diferenças culturais, esteja também relacionado com o nível socioeconômico dos participantes. O caráter mais ativo das meninas ubatubanas e mais rústico de crianças de ambos os sexos em Ubatuba, principalmente, pode ser devido a variáveis relacionadas com o comportamento das classes trabalhadoras, que preponderou fortemente no grupo praiano e que teve uma minoria representada no grupo de São Paulo. Indubitavelmente, é difícil isolar a variável socioeconômica dos demais determinantes culturais. Contudo, pretendemos deixar claro que, apesar de ela não ter sido destacada no presente estudo, reconhecemos sua importância e sugerimos investigações futuras que possam avaliar melhor seus efeitos, estendendo a pesquisa para grupos culturais caracterizados por diferenças socioeconômicas, mas com maior uniformidade em relação a outros aspectos contextuais.

A escolarização por que passavam as crianças da praia, fundamentada nos mesmos moldes das grandes cidades, é, sem dúvida, um fator ponderável de influência cultural. Nessa perspectiva, um aspecto muito interessante, constatado através de entrevistas informais com as educadoras, foram suas afirmações a respeito do desempenho escolar das crianças ubatubanas. Tanto as professoras de pré-escola quanto as do ensino fundamental relataram a facilidade que 
estas crianças tinham de aprender, em contraste com as constantes queixas de professoras de escolas de alunos de mesmo nível socioeconômico da cidade de São Paulo, que geralmente assinalam muitas dificuldades de aprendizagem por parte de seus alunos. As ubatubanas eram crianças que se mostravam exuberantes e alegres em suas brincadeiras, mas que conseguiam manter a concentração em tarefas dirigidas e disposição para realizá-las. Diríamos que eram crianças ativas, mas calmas, provavelmente por não terem de passar pelos fatores estressantes da grande cidade. Outras circunstâncias ecoculturais - como a menor miséria, propiciada pela natureza fértil e as condições climáticas e geográficas da região - são provavelmente fatores que tendem a diminuir o estresse destas crianças e a facilitar seu aproveitamento escolar.

Extrapolando os dados da pesquisa sobre o ciclo sono/vigília realizada por Louzada (2000) - que sugere que os adolescentes ubatubanos estudados revelavam um sono mais reparador do que os paulistanos -, podemos também ponderar que o sono das crianças ubatubanas tenha um efeito mais repousante do que o das paulistanas - fato que tornaria as primeiras mais dispostas para as atividades físicas e intelectuais diárias. Embora o desempenho escolar dos adolescentes que estudou não tenha sido avaliado, Louzada afirma que é provável que a privação parcial de sono resulte numa diminuição do desempenho cognitivo e motor. $\mathrm{O}$ autor aponta alguns elementos que favoreceriam o sono dos adolescentes ubatubanos: a falta de energia elétrica (constatada em $20 \%$ das casas dos adolescentes entrevistasdos) e o tipo de lazer a que se dedicavam: caminhadas, pesca, idas a cachoeiras e prática de surfe.

Outra característica diferencial dos dois grupos culturais diz respeito ao número, constância e familiaridade de pessoas envolvidas na escolarização das crianças. A escola da Praia de Itamambuca tinha um número pequeno de alunos, com apenas uma classe para cada nível escolar. Como a comunidade era pequena, tanto os alunos quanto suas famílias eram conhecidos pelas professoras e vice-versa. $\mathrm{Na}$ creche grande da cidade de São Paulo, o anonimato era muito maior, também porque havia maior rotatividade das educadoras, enquanto as professoras da escola ubatubana eram concursadas e, em sua maioria, trabalhavam na comunidade há muito tempo. Assim sendo, um fato muito importante na escolarização - que é o conhecimento da realidade em que vive o aluno - escapava muito mais às educadoras paulistanas. A maior proximidade da escola ubatubana em relação à comunidade propiciava um clima mais familiar e afetuoso entre educadoras, pais e alunos - fato que, naturalmente, tinha reflexos positivos no aproveitamento escolar e na percepção da escola como algo pertencente a todos. 
Acreditamos que a impressão de maior alegria demonstrada pelas crianças praianas devase ao fato de serem muito sorridentes. Lee-Manoel et al. (2003) encontraram maior exibição de sorrisos com exposição de dentes superiores nas crianças de Ubatuba (Figura 9.1.) do que nas paulistanas. Segundo Otta (1994), o sorriso superior ocorre durante cumprimentos, interações e brincadeiras. Sarra e Otta (2001) relatam que esse tipo de sorriso, mais tipicamente interacional, está associado a um nível intermediário de ativação e de envolvimento. Lee-Manoel (comunicação pessoal) também considera que essa forma de sorriso denota maior envolvimento nas brincadeiras.

Diferenças no comportamento agressivo entre os grupos culturais também foram dignas de nota. Kornadt (2002) comenta que condições ecológicas e socioeconômicas também afetam a agressividade. Cita, como exemplo, o fato de crianças de culturas de pastoreio serem mais agressivas do que as que vivem em sociedades que subsistem por meio da agricultura. Em culturas mais agressivas, as crianças são criadas mediante mais punições e rejeição, em contraste com culturas não agressivas, em que as crianças são tratadas com empatia e compreensão, como é o caso daquela verificada nos índios Parakanã (Gosso et al., no prelo). Kornadt considera, ainda, que, em culturas em que o pai é a figura dominante, as crianças seriam mais agressivas do que naquelas em que há relações íntimas e horizontais entre pai e mãe.

A questão das figuras materna e paterna e dos papéis do homem e da mulher na sociedade, em constante mudança atualmente, merece também ser destacada. Nicolaci-da-Costa (1988) relaciona uma figura de pai dominador com as sociedades que enfatizam a identidade compartilhada. Georgas (2003) comenta que, nas sociedades tradicionais, com o crescimento dos meios de comunicação, do turismo e do comércio, papéis anteriormente consagrados de família vêm mudando: com o maior nível educacional e a entrada das mulheres no mercado de trabalho, os pais não têm mais poder absoluto sobre os familiares. Georgas relata que, em vários países, - e isto não é diferente em muitos lares brasileiros - a mãe, além de trabalhar, cuida da casa e das crianças. Presume-se que essa situação ocorria, também, na maior parte das famílias das crianças de São Paulo. Como vimos pela profissão dos pais, nesse grupo, a mãe era, provavelmente, a principal provedora do sustento da casa. Supomos - por se tratar Ubatuba de uma região de valores mais tradicionais e pela conduta truculenta e o estilo rústico dos meninos - que, na comunidade ubatubana, o pai seja ainda considerado o chefe da família, embora essa realidade esteja mudando com a crescente participação das mulheres no sustento da casa. Esse fator, entretanto, não se mostrou um desequilibrador das relações grupais entre as crianças. 
As meninas ubatubanas, longe de serem submissas aos seus colegas, enfrentavam-nos de igual para igual, provocavam-nos e os acompanhavam muito bem nas brincadeiras mais rudes e turbulentas distais, tendo em vista que o contato proximal ocorria principalmente com crianças do mesmo sexo. Eventuais abordagens mais duras dos colegas eram também respondidas sem hesitação e sem choro. Esse estilo interacional mostrou-se um tanto diferente entre as crianças de São Paulo, grupo em que os meninos se revelaram mais gentis e mais sutis em suas aproximações corporais em relação às meninas. Entretanto, essa característica mais amena da conduta dos meninos de São Paulo - provavelmente adquirida por um modo de criação que incentiva o respeito pelo sexo oposto - não os impediu de participarem juntos com elas de brincadeiras turbulentas distais (dentre as quais se destacaram as de perseguição e fuga), nem de usar algumas táticas pesadas nos conflitos.

Uma das principais diferenças encontradas entre os dois grupos culturais, como já apontaram Lee-Manoel et al. (2003), foi o maior contato corpo-a-corpo nas brincadeiras e conflitos das crianças ubatubanas, quando comparadas com as paulistanas. A nosso ver, o intenso contato físico entre as crianças ubatubanas nas brincadeiras, provocações e conflitos em contraposição com um estilo mais verbal e distal de relacionamento em brincadeiras e disputas das crianças paulistanas - reflete uma cultura que valoriza ou, ao menos, não reprime o contato corporal.

As sociedades não ocidentais, segundo Keller (1998) e Greenfield et al. (2003), estimulam o contato corporal entre crianças e cuidadores mais do que a manipulação independente de brinquedos, incentivada nas sociedades ocidentais. Montagu (1988) refere-se a importantes diferenças idiossincráticas entre famílias e culturas em relação à frequiência de toques, abraços, beijos e carícias. Afirma que existem culturas inteiras partidárias do "não me toque" - o que, evidentemente, não é o caso da cultura brasileira. $\mathrm{O}$ autor diferencia culturas táteis das não táteis e explicita diversas formas de tatilidade. Ao demonstrar fartamente a importância do contato corporal mãe-criança para que essa aprenda o que é proximidade, intimidade, abertura e calor emocional, Montagu fornece a exata dimensão da importância do toque no desenvolvimento.

Pela intensidade de toques apresentada pelas crianças ubatubanas, podemos depreender que, comparada com a de São Paulo, a cultura de Ubatuba é uma cultura de toque. Apesar da importância do contato corporal para o desenvolvimento infantil, devemos, também, considerar que o toque indesejado pode ser invasivo. Nas grandes cidades, pela imensa concentração demográfica, talvez as pessoas precisem mais de espaço pessoal e menos de proximidade 
corporal, enquanto, em vastas áreas inabitados, como é o caso de Ubatuba, é possível que seus moradores necessitem sentir-se mais próximos uns dos outros e que a proximidade corporal seja mais agradável e confortadora - mesmo porque a probabilidade de uma eventual interação com estranhos é muito menor do que a existente num grande centro urbano.

A concepção etológica fundamenta-se no reconhecimento do ser humano como biologicamente sociocultural (Bussab \& Ribeiro, 1998; Rodrigues \& Otta, 2002) e na pressuposição de que adaptações próprias para o ajustamento social já se revelam, em toda a sua plenitude, na infância (Carvalho \& Pedrosa, 2002; Oliva, 2004; Seidl de Moura, 2004). Entender as experiências de crianças com seus pares requer entender processos que funcionam em vários níveis de complexidade e cada nível de complexidade tem propriedades emergentes que não são previsíveis por variáveis de níveis inferiores (Lansord \& Parker, 1999). Assim, características da formação de grupos de brincadeira não podem ser reduzidas meramente a combinações de características e habilidades individuais de seus integrantes, nem apenas a suas histórias pregressas, nem podem ser explicadas somente pela configuração das relações dentro do grupo num dado momento. Há um entrelaçamento de processos e mecanismos que não podem ser facilmente isolados (Bussab, 2003). Cada um deles tem uma forma de agir, de combinar-se e de interagir com os outros na determinação dos fenômenos. Nossas ferramentas ainda não nos possibilitam concluir qual o peso das contribuições específicas de cada um. Entretanto o conhecimento de processos grupais, tais como ocorrem em ambiente natural, tem muito a contribuir para a compreensão geral dos fenômenos interacionais.

As vantagens dos métodos etnográficos e de observação naturalística para a compreensão das interações e das relações sociais são inegáveis e reafirmadas por diversos autores que trabalham dentro de uma perspectiva psicoetológica e, também, por sociólogos e antropólogos. Segundo Rizzo e Corsaro (1995), tais métodos permitem aos pesquisadores abordarem os dinâmicos processos sociais, através de um prolongado envolvimento com o setting e da triangulação de fontes de informação. Possibilitam aos estudiosos a geração de cronologias detalhadas e ecologicamente sensíveis - necessárias para o progresso do entendimento das ações e do desenvolvimento humano. Os autores acrescentam que a ecologia das relações na escola pode esclarecer de que forma processos mais gerais - como fatores disseminados das comunidades, práticas socioculturais e variáveis demográficas - afetam as interações diárias das crianças e seu subseqüente desenvolvimento. 
Bronfenbrenner (1994), em sua concepção do ambiente ecológico como uma série de estruturas encaixadas umas nas outras, afirma que "um avanço maior no entendimento científico dos processos intrapsíquicos e interpessoais básicos do desenvolvimento humano exige sua investigação nos ambientes concretos, tanto imediatos quanto remotos em que os seres humanos vivem" (pág. 11). O autor propõe uma ecologia que abrange os seguintes sistemas: o microssistema, que consiste no complexo de inter-relações dentro do ambiente imediato (ex.: família, escola); o mesossitema, constituído pelo vínculo entre os ambientes do qual a pessoa faz parte (ex. pais e escola); o exossistema, formado por ambientes em que ocorrem eventos que afetam o ambiente imediato da pessoa (ex.: trabalho do pai); e, finalmente, o macrossistema, constituído de um complexo de sistemas interconectados, considerado como manifestação de padrões globais de ideologia e de organização de instituições sociais comuns a uma determinada cultura ou subcultura. Dentro da proposta ecológica de Bronfenbrenner, podemos situar as explicações aventadas para nossos dados na interface entre o macrossitema cultural e o microssistema do grupo de companheiros na escola.

Conforme já explicitamos, Corsaro e Molinari (1990) propõem o termo cultura de pares (peer culture), que é entendido como um conjunto relativamente estável de atividades, produtos, valores e ocupações que um grupo de crianças partilham com os companheiros. Na situação de convívio diário em que nossas crianças foram observadas, havia tempo e contato suficiente para que fosse estabelecida uma microcultura de pares, na qual elas se reconhecessem, aprendessem com seus colegas, fizessem criações coletivas e prolongassem certas práticas e crenças. Corsaro e Molinari ponderam que ações desempenhadas por algumas crianças podem emergir como um modo de participação que passa a constituir um conhecimento coletivo. Por seu caráter constantemente dinâmico, essas ações podem gerar inovações que vêm a ser incorporadas, ao menos temporariamente, num determinado grupo. Carvalho e Rubiano (2004) acrescentam que a estrutura de participação "organiza as atividades das crianças e oferece um roteiro básico que o grupo reconhece (um significado partilhado) e ao qual novas ações e novos objetos podem ser incorporados" (pág. 186). Segundo as autoras, a consolidação das atividades, crenças e valores compartilhados constitui uma peculiar cultura do grupo de brinquedo.

Gosso et al. (no prelo) expressam opinião semelhante, afirmando que as crianças, na brincadeira, vivem numa cultura especial, diferente da adulta. As atividades lúdicas e as relações entre as crianças possibilitam que se forme uma cultura dentro da cultura: a cultura da brincadeira, que, evidentemente, se relaciona com a cultura adulta. Crianças brincam de ser 
culturais e "o nome do jogo é cultura". Os autores acentuam o caráter repetitivo de muitas brincadeiras, que permite a emergência de experiências mais sutis, tanto nos planos cognitivo e motor quanto nas esferas afetiva e social.

As reações dos parceiros de um grupo são moduladas e reguladas dentro de uma determinada estrutura grupal e de uma história construída em comum. Compartilham normas e valores próprios de sua microcultura de grupo de brincadeira, que se espelha na macrocultura e dela incorpora elementos, mas cuja configuração constitui sua identidade e preserva suas características únicas e peculiares de grupo num dado momento de sua história. É certo que os grupos de brincadeira são compostos de crianças que, com suas diferenças individuais, emprestam-lhe características próprias. Contudo, sua configuração como grupo é única. Num dado recorte da história dos grupos das crianças observadas neste estudo, encontramos configurações de significados partilhados - como afirmam Carvalho e Rubiano (2004), ao enunciarem o princípio da sociabilidade a que denominaram persistência de significado -, que pudemos registrar e presenciar num determinado momento, mas que, certamente, mudarão com o correr da história. Por essa razão, seria temerário generalizar os dados obtidos no presente trabalho, que pretendeu contribuir para o corpo de evidências que ressaltam a singularidade dessa única espécie estritamente social, singularmente adaptável e capaz de construir história, chamada Homo sapiens - cuja constituição possibilitou-lhe edificar a cultura e modificá-la no decorrer do tempo, em decorrência de sua capacidade exclusiva de criar novos conhecimentos, de acumulá-los e de avaliá-los. 


\section{REFERÊNCIAS BIBLIOGRÁFICAS}

Altmann, J. (1974). Observational study of behavior sampling methods. Behavior, 49, 227-265.

Andersen, P. A. (1999). Nonverbal communication: Forms and functions. Mayfield: Mountain View, CA.

Archer, J. (1996). Sex differences in social behavior: Are the social role and evolutionary explanations compatible? American Psychologist, 51, 909-917.

Aureli, F. \& de Waal, B. M. (2000). Why natural conflict resolution? In A. Filippo \& F. de Waal (Ed.). Natural conflict resolution (pp. 3-10). Berkeley: University of California Press.

Aureli, F. \& Smucny, D. (2000). The role of emotion in conflict and conflict resolution. In A. Filippo \& F. de Waal (Ed.), Natural conflict resolution (pp 199-224). Berkeley: University of California Press.

Ballif-Spanvill, B., Clayton, C. J \& Hendrix, S. B. (2003). Gender, types of conflict, and individual differences in the use of violent and peaceful strategies among children who have and have no witnessed interparental violence. American Journal of Orthopsychiatry, 73, 141-153.

Bekoff, M. \& Byers, J. A. (1998). Animal Play. Cambridge, UK: Cambridge University Press

Belle, D. (1989). Children's social networks and social supports. New York: Wiley.

Benenson, J. F. (1993). Greater preference among females than males for dyadic interaction in early childhood. Child Development, 64, 544-555.

Benenson, J. F., Nicholson, C., Waite, A., Roy, R. \& Simpson, A. (2001). The influence of group size on children's competitive behavior. Child Development, 72, 921-928.

Berger, P. L. \& Luckmann, T. (1966/1999). A construção social da realidade. Petrópolis: Vozes.

Bernstein, B. (1977). Class, codes and control. London : Routledge \& Kegan. 
Berry, J. W, Poortinga, Y. H., Segall, M. H. \& Dasen, P. R. (1992). Cross-cultural psychology: Research and applications. Cambridge, U.K.: Cambridge University Press.

Bichara, I. D. (2002). Crescer como índio às margens do Velho Chico: um desafio para as crianças Xocó. In E. R. Lordello, A. M. A. Carvalho \& S. Koller (Orgs.), Infância Brasileira e contextos de desenvolvimento (pp.137-163). São Paulo: Casa do Psicólogo; Salvador: EDUFBA.

Bichara, I. D. (2003). Nas águas do Velho Chico. In: A. M. A. Carvalho, C. M. C. Magalhães, F. A. R. Pontes \& I. D. Bichara (Orgs.), Brincadeira e cultura: Viajando pelo Brasil que brinca (pp. 89-107). São Paulo: Casa do Psicólogo.

Bjoklund, D. F. (1997). The role of immaturity in human development. Psychological Bulletin, $122,153-169$.

Bjorklund, D. F. \& Pellegrini, A. D. (2000). Child development and evolutionary psychology. Child Development, 71, 1687-1708.

Bjorklund, D. F. \& Pellegrini, A. D. (2001). The origins of human nature: Evolutionary developmental psychology. Washington, DC: American Psychological Association.

Blurton-Jones, N. (1974/1976). Rough-and-tumble play among nursery school children. In J. S. Bruner, A. Jolly \& K. Silva (Eds.), Play: Its role in development and evolution (pp. 352 363). Middlesex, England: Penguin Books.

Bonta, B. D. (1997). Cooperation and competition in peaceful societies. Psychological Bulletin, $121,299-320$.

Bornstein, M. H., Haynes, M., Pascual, L., Painter, K. M. \& Galperin, C. (1999). Play in two societies: pervasiveness of process, specificity of structure. Child Development, 70, 317 331.

Bronfenbrenner, U. (1994/1996). A ecologia do desenvolvimento humano: experimentos naturais e planejados. Porto Alegre. Artes Médicas, 1996.

Brougère, G. (1998). A criança e a cultura lúdica. Revista da Faculdade de Educação, 24, 103116. 
Brown, S. (1998). Play as an organizing principle: Clinical evidence and personal observations. In M. Bekoff \& J. A. Byers (Eds.), Animal Play (pp. 243-259). Cambridge, UK: Cambridge University Press

Bruner, J. S. \& Sherwood, V. (1976). Peekaboo and the learning of rule structures. Em J. S. Bruner, A. Jolly \& K. Silva (Eds.), Play: Its role in development and evolution (pp. 277285). Middlesex, England: Penguin Books.

Bruner, J. S. (1990). Culture and human development: A new look. Human Development, 33, 344-355.

Bühler, C. (1946). Infancia y juventud. Buenos Aires: Espasa - Calpe.

Bussab, V. S. R. (2002). Nas malhas do apego: Natureza, cultura e desenvolvimento humano. In S. A. S. Leite (Org.), Cultura, cognição e afetividade: A sociedade em movimento (pp.1125). São Paulo: Casa do Psicólogo.

Bussab, V. S. R. (2003). Afetividade e interação social em crianças: perspectiva psicoetológica. Tese de Livre-Docência. Instituto de Psicologia da Universidade de São Paulo.

Bussab, V. S. R. \& Ribeiro, F. L.(1998). Biologicamente cultural. In L. Souza, M. F. Q. Freitas \& M. M. P. Rodrigues (Orgs.), Psicologia: Reflexões impertinentes (pp. 175-193). São Paulo, Casa do Psicólogo.

Carvalho, A. M., Machado, M. G. M. \& Suyama, E. (2002). Afetividade, cultura e cuidado: possibilidades para o desenvolvimento da criança. Em S. A. S. Leite (Org.), Cultura, cognição e afetividade: A sociedade em movimento (pp.39-67). São Paulo: Casa do Psicólogo.

Carvalho, A. M. A. (1989). O lugar do biológico na Psicologia: O ponto de vista da Etologia. Biotemas, 2, 81 -92.

Carvalho, A. M .A. (1998). Etologia e comportamento social. In L. Souza, M. F. Q. Freitas \& M. M. P. Rodrigues (Orgs.), Psicologia: Reflexões impertinentes (pp. 175-193). São Paulo: Casa do Psicólogo.

Carvalho, A. M. A., Beraldo, K., Santos, F. \& Ortega, R. (1993). Brincadeiras de menino, 
brincadeiras de menina. Psicologia: Ciência e Profissão, 13, 30 -33.

Carvalho, A. M.A. \& Pedrosa, M. I. (2002). Cultura no grupo de brinquedo. Estudos de Psicologia, 7, 181-188.

Carvalho, A.M.A., Magalhães, C. M. C., Pontes, F. A. R. \& Bichara, I. D. (Eds.), Brincadeira e cultura: Viajando pelo Brasil que brinca. São Paulo: Casa do Psicólogo.

Carvalho, A. M. A. \& Pontes, F. A. R. (2003). Brincadeira é cultura. In: A. M. A. Carvalho, C. M. C. Magalhães, F. A. R. Pontes \& I. D. Bichara (Eds.), Brincadeira e cultura: Viajando pelo Brasil que brinca (pp. 15-32). São Paulo: Casa do Psicólogo.

Carvalho, A. M. A. \& Rubiano, M. R. B. (2004). Vínculo e compartilhamento na brincadeira de crianças. In M. C. Rossetti-Ferreira, K. S. Amorim, A. P. S. Silva \& A.M.A. Carvalho (Orgs.), Rede de significações e o estudo do desenvolvimento humano (pp.171-187). Porto Alegre: Artmed.

Charlesworth, W. R. (1996). Co-operation and competition: Contributions to an evolutionary and developmental model. International Journal of Behavioral Development, 19, 25 -39.

Charlesworth, W .R. \& La Freniere, P. J. (1983). Dominance, friendship utilization and resource utilization in preschool children's groups. Ehtology and Sociobiology, 4, 175-186.

Chung, T. Y. \& Asher, S. R. (1996). Children's goals and strategies in peer conflict situations. Merrill-Palmer Quarterly, 42, 165-176.

Connellan, H., Baron-Cohen, S., Wheelwright, S., Batki, A \& Abluwalia, J. (2000). Sex differences in human neonatal social perception. Infant Behavior and Development, 23, 113118.

Conway, L. G., Ryder A. G., Tweed, R. G. \& Sokol, B. W. (2001). Intranational cultural variation: Exploring further implications of collectivism within the United States. Journal of Cross-Cultural Psychology, 32, 681-697.

Coplan, R. J., Gavinski-Molina, M. H., Lagacé-Séguin, D. G. \& Whichmann, C. (2001). When girls versus boys play alone: Nonsocial play and adjustment in kindergarten. Developmental Psychology, 37, 464-474. 
Corsaro, W. (1994). Discussion, debate and friendship: peer discourse in nursery schools in the United States and Italy. Sociology of Education, 67, 1-26.

Corsaro, W. A. \& Molinari, L. (1990). From seggiolini to discussione: The generation and extension of peer culture among Italian preschool children. Qualitative Studies in Education, 3, 213-320.

Creusere, M. A. (1999). Theories of adults' understanding and use of irony and sarcasm: Applications to and evidence from research with children. Developmental Review, 19, 213262.

Crystal, D. S., Watanabe, H. \& Chen, R. S. (2000). Preference for diversity in competitive and cooperative contexts: A study of American and Japanese children and adolescents. International Journal of Behavioral Development, 24, 348-355.

De Conti, L. \& Sperb, T. M. (2001). O brinquedo de pré-escolares: Um espaço de ressignificação cultural. Psicologia: Teoria e Pesquisa, 17, 59 - 67.

Dell'Aglio, D. D. \& Hutz, C. S. (2002). Estratégias de coping e estilo atribucional de crianças em eventos estressantes. Estudos de Psicologia (Natal), 7, 5-13.

De Waal, F. M. B. (2000). The first kiss. In A. Filippo \& F. de Waal (Ed.), Natural conflict resolution (pp 15-33). Berkeley: University of California Press.

Dunn, J. \& Slomkowsky, C. (1992). Conflict and the development of social understanding. Em C. U. Shantz \& W. W. Hartup (Eds.), Conflict in child and adolescent development (pp. 7092). Cambridge: Cambridge University Press.

Eibl-Eibesfeldt, I. (1970). Ethology, the biology of behavior. New York: Holt, Rinehat \& Winston.

Eibl-Eibesfeldt, I. (1974). The myth of the aggression-free hunter and gatherer society. In R. L. Holloway (Ed.), Primate aggression, territoriality, and xenophobia (pp.435-457). London: Academic Press.

Eibl-Eibesfeldt, I. (1989). Human Ethology. New York: Aldine de Gruyter. 
Eisenberg, A. R. \& Garvey, C. (1981). Children's use of verbal strategies in resolving conflicts. Discourse Processes, 4, 149-170.

Fabes, R. A., Martin, C. L., Hanish, L. D., Anders, M. C. \& Madden-Derdich, D. A. (2003).

Early school competence: The roles of sex-segregated play and effortful control. Developmental Psychology, 39, 848-858.

Fabes, R. A., Martin, C. L. \& Hanish, L. D. (2003). Young children's play quality in same-, other-, and mixed-sex peer groups. Child Development, 74, 921-923.

Fagen, R. (1981). Animal play behavior. Oxford: Oxford University Press.

Farris, C. S. P. (2000). Cross-sex peer conflict and the discursive production of gender in a Chinese preschool in Taiwan. Journal of Pragmatics, 32, 539-568.

Farver, J. M. \& Howes, C. (1993). Cultural differences in American and Mexican mother-child pretend play. Merill-Palmer Quarterly, 39, 344-358.

Farver, J. M. \& Wimbart S. (1995). Indonesian children's play with their mothers and older siblings. Child Development, 66, 1493-1503.

Farver, J. M., Kim, Y. K. \& Lee-Shin, Y. (2000). Within cultural differences: Examining individual differences in Korean American and European American preschoolers' social pretend play. Journal of Cross-Cultural Psychology, 31, 583-602.

Farver, J. M. \& Lee-Shin, Y. (1997). Social pretend play in Korean- and Anglo-American preschoolers. Child Development, 68, 544-556.

Fein, G. (1981). Pretend play in childhood: An integrative review. Child Development, 52, 1095 $-1118$.

Feldman, E. \& Dodge, K.A. (1987). Social information processing and sociometric status: Sex, age, and situational effects. Journal of Abnormal Child Psychology, 15, 211-227.

Freud, S. (1920/1968). Mas allá del principio del placer. Obras Completas. Vol. 1. Madrid: Editorial Biblioteca Nueva. 
Fry, D. P. (1988). Intercommunity differences in aggression among Zapotec children. Child Development, 59, 237-245.

Friedmann, A. (1992). A evolução do brincar. In A. Friedmann et al., O direito de brincar: A brinquedoteca (pp. 23 -31). São Paulo: Scritta/ ABRINQ.

Fundação Seade (2004) - Fundação Sistema Estadual de Análise de Dados. Perfil Municipal. Disponível em: www.seade.gov.br. Acessado em junho de 2004.

Garvey, C. (1984). Children's talk. Cambridge, MA: Harvard University Press.

Georgas, J. (2003). Family: Variations and changes across cultures. In W. J. Lonner, D. L. Dinnel, S. A. Hayes \& D. N. Sattler (Eds.), Online Readings in Psychology and Culture (Unit 13, Chapter 3). Disponível em www.wwu.edu/ culture. Acessado em abril de 2004.

Georgesen, J. C., Harris, M. J., Milich, R. \& Young, J. (1999). “Just teasing ...” Personality effects on perceptions and life narratives of childhood teasing. Personality and Social Psychology Bulletin, 10, 1254-1267.

Göncü, A., Mistry, J. \& Mosier, C. (2000). Cultural variations in the play of toddlers. International Journal of Behavioral Development, 24(3), 321-329.

Gosso, Y, Morais, M. L. S \& Otta, E. (2002) Estudo Comparativo do faz-de-conta de crianças de três comunidades brasileiras: um grande centro urbano, uma zona rural e uma aldeia indígena. XXXII Reunião Anual de Psicologia. Florianópolis: 23 a 26 de outubro de 2002.

Gosso, Y. \& Otta, E. (2003). Em uma aldeia Parakanã. In A. M .A. Carvalho, C. M. C. Magalhães, F. R. Pontes \& I. D. Bichara (Orgs.), Brincadeira e Cultura: Viajando pelo Brasil que brinca (Vol. I, pp. 33-76). São Paulo: Casa do Psicólogo.

Gosso, Y., Morais, M. L. S \& Otta, E. (2003). Pivôs utilizados nas brincadeiras de faz-de-conta de crianças de três comunidades brasileiras: um grande centro urbano, uma zona rural e uma aldeia indígena (pp.69-70). In Anais, III Congresso Norte-Nordeste de Psicologia, Vol II. João Pessoa, PA, 2003. João Pessoa, PA: Associação de Pesquisa em Psicologia. 
Gosso, Y., Otta, E., Morais, M. L. S., Ribeiro, F. J. L. \& Bussab, V. S. R. (no prelo). Play in hunter-gatherer society. In A. D. Pellegrini \& P. K. Smith (Eds.), The Nature of Play: Great Apes and Humans. New York: Guilford.

Green, S. B., Salkind, N. J. \& Akey, T. M. (2000). Using SPSS for Windows: Analyzing and understanding data. New York: Prentice Hall.

Greenfield, P. M., Keller, H., Fuligni, A. \& Maynard, A. (2003). Cultural pathways through universal development. Annual Review of Psychology. Disponível em http://infotrac.galegroup.com. Acessado em abril de 2004.

Gregor, T. (1982). Mehináku: o drama da vida diária em uma aldeia do Alto Xingu. São Paulo: Nacional.

Groos, K. (1901/1976). The play of man: Teasing and love play. In J. S. Bruner, A. Jolly \& K. Sylva (Eds.), Play: Its role in development and evolution (pp.65-67). Middlesex, England: Penguin Books.

Harris, J.R.(1998). Diga-me com quem anda ... Rio de Janeriro: Objetiva.

Hartup, W.W. (1983). Peer relations. In P. H. Mussen \& E. M. Hetherington (Eds.), Handbook of child psychology. Vol. 4. (pp. 103-196). New York: Wiley.

Hartup, W.W., Laursen, B., Stewart, M. I. \& Eastenson, A. (1988). Conflict and the friendship relations of young children. Child Development, 59, 1590-1600.

Hartup, W. W., French, D. C., Laursen, B., Johnston, M. K. \& Ogawa, J. R. (1993). Conflict and friendship relations in middle childhood: Behavior in a closed-field situation. Child Development, 64, 445-454.

Hawley, P. (2002). Social dominance and prosocial and coercive strategies of resource control in preschoolers. International Journal of Behavioral Development, 26, 167-176.

Hinde, R. A. (1987). Individuals, relationships and culture: Links between Ethology and Social Sciences. Cambridge, UK: Cambridge University Press. 
IBGE (2004) - Instituto Brasileiro de Geografia e Estatística. Censo de 2000. Disponível em http://www.ibge.gov.br. Acessado em junho de 2004

Jimerson, T. L. \& Bond, L. A. (2001). Mothers' epistemologies, turn-taking, and contingent interaction with preschoolers. Applied Developmental Psychology, 22, 379-396.

Kagan, S., Knight, G. P., Martinez, S. \& Santana, P. E. (1981). Conflict resolution style among Mexican children. Journal of Cross-Cultural Psychology, 12, 222-232.

Keller, H. (1998). Diferentes caminhos de socialização até a adolescência. Revista Brasileira de Crescimento e Desenvolvimento, 8, 01-14.

Keller, H. (1999). The role of development for understanding the biological basis of cultural learning. Paper read at the Symposium Theories of individual development, demarcating and integrating metaperspective, Wittneberg, Germany, November $5^{\text {th }}-8^{\text {th }}$.

Keltner, D., Capps, L., Kring, A. M., Young, R. C. \& Heerey, E. A. (2001). Just teasing: A conceptual analysis and empirical review. Psychological Bulletin, 127, 229 - 248.

Killen, M. \& Turiel, E. (1991). Conflict resolution in preschool social interactions. Early Education and Development, 2, 240-255.

Kowalski, R. M. (2000). “I was only kidding”: Victims' and perpetrators' perceptions of teasing. Personality and Social Psychological Bulletin, 26, 231-241.

Kornadt, H. J. (2002). Social motives and their development in cultural context. In W. J. Lonner, D. L. Dinnel, S. A. Hayes \& D. N. Sattler (Eds.), Online Readings in Psychology and Culture (Unit 15, Chapter 6). Disponível em www.wwu.edu/ culture. Acessado em abril de 2004.

LaFreniere, P., Strayer, F. F. \& Gauthier, R. (1984). The emergence of same-sex affiliative preferences among preschool peers: A developmental/ethological perspective. Child Development, 55, 1958-1965.

LaFreniere, P.J. (1996). Co-operation as a conditional strategy among peers: Influence of social ecology and kin relations. International Journal of Behavioral Development, 19, 39-52. 
LaFreniere, P. J. \& MacDonald, K. B. (1996). Evolutionary perspectives on children's resourcedirected behaviour in peer relationship: An introduction. International Journal of Behavioral Development, 19, 1-5.

Lansford, J. E. \& Parker, J. G. (1999). Children's interactions in triads: Behavioral profiles and effects of gender and patterns of friendship among members. Developmental Psychology, $35,80-93$.

Laursen, B., Finkelstein, B. D. \& Betts, N. T. (2001). A developmental meta-analysis of peer conflict resolution. Developmental Review, 21, 423-449.

Laursen, B. \& Hartup, W. W. (1989). The dynamics of preschool children's conflicts. MerrillPalmer Quarterly, 35, 281-297.

Laursen, B., Hartup, W. W. \& Koplas, A. L. (1996). Towards understanding peer conflict. Merrill-Palmer Quarterly, 42, 76-102.

Lee-Manoel, C. L., Morais, M. L. S, Bussab, V. S. \& Otta, E. (2003). A naturalistic study of social touch, self-touch and smiling in preschool children of two communities: small scale vs. urban. XXVIII International Ethological Conference. Florianópolis, SC, 2003.

Ljungberg, T., Wetlund, K. \& Forsberg, A. J. L (1999). Conflict resolution in 5-year-old boys: Does postconlict affiliative behaviour have a conciliatory role? Animal Behaviour, 58, 10071016.

Lock, A. J. (2000). Phylogenetic time and symbol creation: Where do zopeds come from? Culture \& Psychology, 6, $105-129$.

Lorenz, K. (1966). On aggression. New York: Harcourt, Brace \& World, Inc.

Louzada, F.M. (2000). Um estudo sobre a expressão da ritmicidade biológica em diferentes contextos sócio-culturais: o ciclo vigília/sono de adolescentes. Tese de Doutorado. Instituto de Psicologia da Universidade de São Paulo.

Lyons, D. M. (1993). Conflict as a constructive force in social life. In W.A. Mason \& S.P. Mendoza (Eds.), Primate social conflict (pp. 387-408). New York: State University Press. 
Maccoby, E. E. (1988). Gender as a social category. Developmental Psychology, 24, 755-765.

Maccoby, E. E. (1996). Peer conflict and intrafamily conflict: Are there conceptual bridges? Merrill-Palmer Quarterly, 42, 165-176.

Maccoby, E. E. \& Jacklin, C. N. (1987). Gender segregation in childhood. In F. H. Reese (Ed.), Advances in child development and behavior, 20, 239-287.

Magalhães, C. M. C. (1995). Agressão, aliança e reconciliação em crianças pré-escolares. Tese de Doutorado. Instituto de Psicologia da Universidade de São Paulo.

Magalhães, C. M. C., Souza, A. R. \& Carvalho, A. M. A. (2003) Piras no Riacho Doce. In A. M. A.Carvalho, C. M. C. Magalhães, F. R. Pontes \& I. D. Bichara (Orgs.), Brincadeira e Cultura: Viajando pelo Brasil que brinca (Vol. I, pp. 77-88). São Paulo: Casa do Psicólogo.

Marcílio, M. L. (1986). Caiçara: Terra e População. Estudo de Demografia Histórica e da História Social de Ubatuba. São Paulo: Paulinas.

Markovits, H., Benenson, J. \& Dolensky, E. (2001). Evidence that children and adolescents have internal models of peer interactions that are gender differentiated. Child Development, 72, $879-886$.

Martin, C. L. \& Fabes, R. A. (2001). The stability and consequences of young children's samesex peer interactions. Developmental Psychology, 37, 431-446.

Mason, W. A. \& Mendoza, S. P. (1993). Primate social conflict: An overview of sources, forms and consequences. In W. A. Mason \& S. P. Mendoza (Eds.), Primate social conflict (pp. 111). New York: State University Press.

Mason, W.A. (1993). The nature of social conflict: A psycho-ethological perspective. In W. A. Mason \& S. P. Mendoza (Eds.), Primate social conflict (pp. 13-47). New York: State University Press.

Maynard, D. (1985). On the function of social conflict among children. American Sociological Review, 50, 207-223. 
McLoyd, V. C. (1983). The effects of the structure of play objects on the pretend play of lowincome preschool children. Child Development, 54, 626-635.

Migliavacca, E. M. (2003). A consciência no mito: Prometeu e Satã. Psychê, 12, 27-45.

Migliavacca, E. M. (2004). A dimensão trágica do psiquismo: um ensaio na perspectiva psicanalítica. Tese de Livre-Docência. Instituto de Psicologia da Universidade de São Paulo.

Miller, P. M., Danaher, D. L. \& Forbes, D. (1986). Sex-related strategies for coping with interpersonal conflict in children aged five and seven. Developmental Psychology, 22, 543548.

Morais, M. L. S. (1980). O faz-de-conta e a realidade social da criança. Dissertação de Mestrado, Instituto de Psicologia da Universidade de São Paulo.

Morais, M. L. S. \& Carvalho, A. M. A. (1994). Faz-de-conta: Temas, papéis e regras na brincadeira de crianças de quatro anos. Boletim de Psicologia, 100-101, 21-30.

Morais, M. L. S., Otta, E. \& Scala, C. (2001). Status sociométrico e avaliação de características comportamentais: Um estudo de competência social em pré-escolares. Psicologia: Reflexão e Crítica, 14, 119-131.

Morais, M. L. S. \& Otta, E. (2003a). Entre a serra e o mar. In A.M.A.Carvalho, C.M.C. Magalhães, F.R. Pontes \& I. D. Bichara (Orgs.), Brincadeira e Cultura: Viajando pelo Brasil que brinca (Vol. I, pp. 127 -156). São Paulo: Casa do Psicólogo.

Morais, M. L. S. \& Otta, E. (2003b). Pretend play in two Brazilian communities (p.50). In Anais: $33^{\text {rd }}$. Annual Meeting of Jean Piaget Society: Play and Development, 2003. Chicago, Illinois.

Montagu, A. (1988). Tocar : O significado humano da pele. São Paulo: Summus.

Moreno, J. L. (1983) Psicodrama. São Paulo: Cultrix. 
Moisés, D. (2003, 15 de dezembro). Expedição conta como brincam os índios: brinquedos, jogos e brincadeiras. $O$ Estado de São Paulo, p.A8.

Murphy, B. C. \& Einsenberg, N. (1996). Provoked by a peer: children's anger-related responses and their relations to social functioning. Merril-Palmer Quarterly, 42, 103-124.

Murphy, B. C. \& Einsenberg, N. (2002). An integrative examination of peer conflict: children's reported goals, emotions, and behaviors. Social Development, 11, 534-557.

Naylor, P. \& Cowie, H. (1999). The effectiveness of peer support systems in challenging school bullying: The perspectives and experiences of teachers and pupils. Journal of Adolescence, $22,467-479$.

Nicolaci-da-Costa, A. M. (1988). Estruturas sociais e subjetividade. In Anais, XVIII Reunião Anual de Psicologia (pp. 633-642), 1988. Ribeirão Preto, SP.

Nicolopoulou, A. \& Weintraub, J. W. (1998). Individual and collective representations in social context: A modest contribution to resuming the interrupted project of a sociocultural development psychology. Human Development, 41, 215-235.

Nunes, A. (1999). A sociedade das crianças A'uwe-Xavante: por uma antropologia da criança. Lisboa: Ministério da Educação / Instituto de Inovação Cultural.

Nunes, A. (2002). No tempo e no espaço: brincadeiras das crianças A’uwe-Xavante. In A. L. Silva, A. V. L. S. Macedo \& A. Nunes (Eds.), Crianças indígenas: ensaios antropológicos (pp. 64-99). São Paulo: Global.

Ogbu, J. U. (1993). Differences in cultural frame of reference. International Journal of Behavioral Development, 16, 483-506.

Oliva, A. D. (2004). A noção de estado inicial e concepções de desenvolvimento: problemas e necessidade de definições empíricas dos termos. In M. L. Seidl de Moura (Org.), O bebê do século XXI e a psicologia em desenvolvimento (pp. 61-110). São Paulo: Casa do Psicólogo.

Oliveira, P. S. (1982). Brinquedos artesanais e expressividade cultural. Série Lazer. Vol.4. São Paulo: SESC-CELAZER. 
Oliveira, W. (1977). Ubatuba: documentário. São Paulo: Editora do Escritor.

Otta, E. (1994). O sorriso e seus significados. Petrópolis: Vozes, 1994.

Otta, E. \& Souza, I. J. F. C. (1999). Crianças alfa e crianças ômega: Um estudo sobre papéis desempenhados num grupo de pré-escola.. In A. M. Carvalho (Org.). O mundo social da criança: Natureza e cultura em ação. São Paulo (pp. 33-51). São Paulo: Casa do Psicólogo.

Papalia, D. E \& Olds, S. W. (1979). A child's world: infancy through adolescence (p. 373). New York: McGraw-Hill.

Parker, S. T. (1984). Playing for keeps: An evolutionary perspective on human games. In P. K. Smith (Ed.), Play in animals and humans (pp. 271-293). Oxford, UK: Basil Blackwell.

Pedrosa, M. I. \& Carvalho, A. M. A. (1995). A interação social e a construção da brincadeira. Cadernos de Pesquisa, 93, 60-65.

Pellegrini, A. D. (1993). Boys' rough-and-tumble play, social competence and group composition. British Journal of Developmental Psychology, 11, 237-248.

Pellegrini, A. D. (1995). Boys' rough-and-tumble play and social competence. In A. D. Pellegrini (Ed.), The future of play theory: A multidisciplinary inquiry into the contributions of Brian Sutton-Smith (pp.107-126). Albany, NY: State University of New York Press.

Pellegrini, A. D. \& Smith, P. K. (1998). Physical activity play: The nature and function of a neglected aspect of play. Child Development, 59, 577-598.

Peller, L. E. (1952/1976). Models of children's play. Em R. E. Heron \& B. Sutton-Smith (Eds.), Child's Play (pp.110-125). New York: John Wiley \& Sons.

Piaget, J (1970). Piaget's theory. In P. H. Mussen (Ed.), Carmichael's Manual of Child Psychology (Vol.1, pp. 99-128). New York: Academic Press.

Piaget, J. (1945/1975). A formação do símbolo na criança. Rio de Janeiro: Zahar.

Pinker, S. (2002). The blank slate: The modern denial of human nature. London: Penguin Books. 
Rabinovich, E. P. Nos tempos dos avós. In A. M. A.Carvalho, C. M. C. Magalhães, F. R. Pontes \& I. D. Bichara (Orgs.), Brincadeira e Cultura: Viajando pelo Brasil que brinca (Vol. II, pp. 9-30). São Paulo: Casa do Psicólogo.

Ribas, R. de C. Jr., Seidl de Moura, M. L., Soares, I. D., Gomes, A. A. N. \& Bornstein, M. H. (2003). Socioeconomic status in Brazilian psychological research: I.validity, measurement, and application. Estudos de Psicologia (Natal), 8, 375-383.

Rizzo, T. A. \& Corsaro, W. A. (1995). Social support processes in early childhood friendship: A comparative study of ecological congruences in enacted support. American Journal of Community Psychology, 23, 389+. Disponível em www.questia.com. Acessado em abril de 2004.

Rodrigues, M. P. M. \& Otta, E. (2002). Desenvolvimento sócio-afetivo de bebês: Alguns fundamentos evolutivos. In S.A.S. Leite (Org.), Cultura, cognição e afetividade: A sociedade em movimento (pp.69-84). São Paulo: Casa do Psicólogo.

Rose, A. J. \& Asher, S.R. (1999) Children's goals and strategies in response to conflicts within a friendship. Developmental Psychology, 15, 69-79.

Sager, F. \& Sperb, T. M. (1998). O brincar e os brinquedos nos conflitos entre crianças. Psicologia: Reflexão e Crítica,11, 309-326.

Sánchez-Martin, J. R., Fano, E., Ahedo, L., Cardas, J., Brain, P. F. \& Azpíroz, A. (2000). Relating testosterone levels and free play social behavior in male and female preschool children. Psychoneuroendocrinology, 25, 773-783.

Santos, J. E. F. (2003). Brincando na maré: Infância e brincadeiras em Novos Alagados. In A. M. A.Carvalho, C. M. C. Magalhães, F. R. Pontes \& I. D. Bichara (Org.), Brincadeira e Cultura: Viajando pelo Brasil que brinca (Vol. I, pp. 109-126). São Paulo: Casa do Psicólogo, 2003.

Santos, E. C. \& Koller, S. H. (2003). Brincando na rua. In Carvalho, C. M. C. Magalhães, F. R. Pontes \& I. D. Bichara (Orgs.), Brincadeira e Cultura: Viajando pelo Brasil que brinca (Vol. I, pp.187- 206). São Paulo: Casa do Psicólogo, 2003. 
Sarra, S. \& Otta, E. (2001). Different types of smiles and laughter in preschool children. Psychological Reports, 89, 547-558.

Seidl de Moura, M. L. (2003). Cross-cultural studies of human development: Some theoretical and methodological considerations (pp.132-134). In Anais, IV Congresso Brasileiro de Psicologia do Desenvolvimento: Contextos de desenvolvimento, educação e cultura. João Pessoa, PA, 2003. João Pessoa, PA: Editora Universitária.

Seidl de Moura, M. L. (2004). Evidências sobre características de bebês recém-nascidos: um convite a reflexões teóricas. In M. L. Seidl de Moura (Org.), O bebê do século XXI e a psicologia em desenvolvimento (pp. 21-59). São Paulo: Casa do Psicólogo.

Serbin, L. A., Sprafkin, C., Elman, M. \& Doyle, A. B (1984). The early development of sex differentiated patterns of social influence. Canadian Journal of Social Science, 14, 350-363.

Setti, K. (1985). Ubatuba nos cantos das praias. São Paulo: Ática.

Shantz, C. U. (1987). Conflicts between children. Child Development, 58, 283-305.

Shantz, C. U. \& Hartup, W. W. (1992).Conflict and development: An introduction. In C. U. Shantz \& W. W. Hartup (Eds.), Conflict in child and adolescent development (pp. 1-11). Cambridge: Cambridge University Press.

Shantz, D. W. (1986). Conflict, aggression, and peer status: An observational study. Child Development, 57, 1322-1332.

Shapiro, J. P., Baumeister, R. F. \& Kessler, J. W. (1991). A three component model of children's teasing: Aggression, humor and ambiguity. Journal of Social and Clinical Psychology, 10, 459-472.

Sheldon, A. (1992). Conflict talk: Sociolinguistic challenges to self-assertion and how girls meet them. Merrill-Palmer Quarterly, 38, 95-117.

Sippola, L. K., Bukowski, W. M. \& Noll, R. B. (1997). Dimensions of liking and disliking underlying the same-sex preference in childhood and early adolescence. Merrill-Palmer Quarterly, 43, 591-609. 
Smith, P.B. (2002). Levels of analysis in cross-cultural psychology. In W. J. Lonner, D. L. Dinnel, S. A. Hayes \& D. N. Sattler (Eds.), Online Readings in Psychology and Culture (Unit 2, Chapter 7). Disponível em www.wwu.edu/ culture. Acessado em abril de 2004.

Smith, P. K. (1982). Does play matter? Functional and evolutionary aspects of animal and human play. Behavioral and Brain Sciences, 5, 139-184.

Smith, P. K. (1988). The role of rough and tumble play in the development of social competence: Theoretical perspectives and empirical evidence. In B. H. Schneider, G. Attili, J. Nadel \& R. P. Weisenboy (Eds.). Social competence in developmental perspective (pp. 239-255). London: Khuver Acad. Pub.

Smith, P. K. (2002). Pretend play, metarepresentation and theory of mind. In: R. Mitchell (Ed.), Pretending and Imagination in Animals and Children (pp. 129-141). Cambridge: Cambridge University Press.

Smith. P. K. \& Pellegrini, A.D. (no prelo). Play in great apes and humans: Reflections on continuities and discontinuities. In A. D. Pellegrini \& P. K. Smith (Eds.), The Nature of Play: Great Apes and Humans. New York: Guilford.

Souza, F. \& Rodrigues, M. M. P. (2002). A segregação sexual na interação de crianças de 8 e 9 anos. Psicologia: Reflexão e Crítica, 15, 489-496.

Striano, T., Tomasello, M. \& Rochat, P. (2001). Social and object support for early symbolic play. Developmental Science, 4(4), 442-455.

Sutton-Smith, B. (1986). Toys as culture. New York: Gardner.

Sylva, K., Bruner, J. S. \& Genova, P. (1976). The role of play in the problem-solving of children 3-5 years old. In J. S. Bruner, A. Jolly \& K. Silva (Eds.), Play: Its role in development and evolution (pp. 246-257). Middlesex, England: Penguin Books.

Taylor, M. \& Carlson, S. M (1997). The relation between individual differences in fantasy and theory of mind. Child Development, 68, 436-455.

Theimer, C. E., Killen, M. \& Strangor, C. (2001) Young children's evaluations of exclusion in gender-stereotypic peer contexts. Developmental Psychology, 37, 18-27. 
Tinbergen, N. (1959). Comparative studies of the behaviour of gulls (Laridae): A progress report. Behaviour, 15, 1-70.

Tomasello, M., Kruger, A. C. \& Ratner, H. H. (1993). Cultural learning. Behavioral and Brain Sciences, 16, 495-552.

Tooby, J. \& Cosmides, L. (1987). Evolutionary psychology and the generation of culture. Part I. Ethology and Sociobiology, 10, 29-49.

Triandis, H. C. (2002). Subjective culture. In W. J. Lonner, D.L. Dinnel, S.A. Hayes \& D.N. Sattler (Eds.), Online Readings in Psychology and Culture (Unit 15, Chapter 1). Disponível em www.wwu.edu/ culture. Acessado em abril de 2004.

Tudge, J. (2003). Studying culture from an ecological-contextualist perspective (p.43). In A. A. Dias e A. Roazzi (Orgs.), Anais, IV Congresso Brasileiro de Psicologia do Desenvolvimento, 2003, João Pessoa, PA. João Pessoa: Editora Universitária,

Underwood, M. K., Schockner, A. E. \& Hurley, J. C. (2001). Children's responses to same- and other-gender peers. An experimental investigation with 8-,10-, and 12-year-olds. Developmental Psychology, 37, 362-372.

Valsiner, J. \& Cairns, R. B. (1992) Theoretical perspectives on conflict and development. Em C. U. Shantz \& W. W. Hartup. (Eds.), Conflict in child and adolescent development (pp. 15 35). Cambridge: Cambridge University Press.

Verbeek, P., Hartup, W. W. \& Collins, W. A. (2000). Conflict management in children and adolescents (pp. 34-53). In A. Filippo \& F. de Waal (Ed.), Natural conflict resolution. Berkeley: University of California Press.

Vygotsky, L. S. (1984). A formação social da mente. São Paulo: Martins Fontes.

Walters, A. E., Stuhlmacher, A. F. \& Meyer, L. L. (1998). Gender and negotiator competitiveness: A meta-analysis. Organizational Behavior and Human Decision Processes, 76, 1-29. 
ANEXO A - Relação das crianças que participaram da pesquisa

Crianças cujos dados foram computados para as análises estatísticas

\begin{tabular}{|c|c|c|c|c|c|c|c|}
\hline Criança & Origem & Sexo & $\begin{array}{l}\text { Idade } \\
\text { (meses) }\end{array}$ & Criança & Origem & Sexo & \begin{tabular}{|l} 
Idade \\
(meses)
\end{tabular} \\
\hline Aça & Ubatuba & $F$ & 70 & Gui & São Paulo & $M$ & 60 \\
\hline Ale & Ubatuba & $F$ & 64 & Gus, Gu & São Paulo & $M$ & 60 \\
\hline And & Ubatuba & $F$ & 68 & $\lg$ & Ubatuba & $M$ & 69 \\
\hline $\mathrm{Br} / \mathrm{Bra}$ & São Paulo & $F$ & 54 & Ja & Ubatuba & $F$ & 67 \\
\hline CC & São Paulo & $F$ & 59 & Le, LR & Ubatuba & $M$ & 68 \\
\hline $\mathrm{Ce}, \mathrm{CM}$ & São Paulo & $M$ & 53 & Leo & São Paulo & $M$ & 63 \\
\hline $\mathrm{Cla}$ & São Paulo & $F$ & 58 & Le, LO & São Paulo & $F$ & 60 \\
\hline CM. Ca & São Paulo & $F$ & 63 & Mar & Ubatuba & $M$ & 63 \\
\hline $\mathrm{Da}$ & São Paulo & $M$ & 58 & Mat & Ubatuba & $M$ & 63 \\
\hline Dan, DD & São Paulo & $M$ & 57 & $\mathrm{Mi}$ & Ubatuba & $F$ & 63 \\
\hline Di, Dbo & São Paulo & $M$ & 60 & $\mathrm{~Pa}$ & São Paulo & $\mathrm{F}$ & 62 \\
\hline $\mathrm{EC}, \mathrm{El}$ & São Paulo & $F$ & 60 & $\mathrm{Pe} \mathrm{Be}, \mathrm{Pe}$ & São Paulo & $M$ & 63 \\
\hline $\mathrm{Fe}, \mathrm{LF}$ & Ubatuba & $M$ & 60 & $\operatorname{Re}$ & São Paulo & $\mathrm{F}$ & 57 \\
\hline Fran & Ubatuba & $F$ & 59 & $\mathrm{Ta}$ & Ubatuba & $F$ & 67 \\
\hline $\mathrm{Ga}$ & Ubatuba & $M$ & 61 & Tam & Ubatuba & $F$ & 66 \\
\hline $\mathrm{Ga}$ & São Paulo & $M$ & 60 & ViRa, Vi & São Paulo & $F$ & 62 \\
\hline Gabi, Gai & Ubatuba & $F$ & 65 & Wa & Ubatuba & $M$ & 65 \\
\hline Gab & São Paulo & $G$ & 54 & Ya & Ubatuba & $M$ & 67 \\
\hline Gag & Ubatuba & $F$ & 66 & $Y n$ & Ubatuba & $M$ & 61 \\
\hline Guc & São Paulo & $M$ & 64 & & & & \\
\hline
\end{tabular}


Crianças que figuram apenas nos exemplos

\begin{tabular}{|l|l|l|c||l|l|l|c|}
\hline Criança & Origem & Sexo & Idade & Criança & Origem & Sexo & Idade \\
\hline Dig, DG & São Paulo & $\mathrm{M}$ & 58 & Pebi & São Paulo & $\mathrm{M}$ & 54 \\
\hline Jo & São Paulo & $\mathrm{M}$ & 57 & Ri, RS & São Paulo & $\mathrm{M}$ & 57 \\
\hline La & São Paulo & $\mathrm{F}$ & 56 & Ro, Rob & São Paulo & $\mathrm{M}$ & 59 \\
\hline Lê, LR & São Paulo & $\mathrm{F}$ & 54 & Tho & São Paulo & $\mathrm{M}$ & 55 \\
\hline Fe & São Paulo & $\mathrm{M}$ & 53 & Vi & São Paulo & $\mathrm{M}$ & 62 \\
\hline Mar & São Paulo & $\mathrm{M}$ & 56 & Vi Fe & São Paulo & $\mathrm{F}$ & 55 \\
\hline Mga, MG & São Paulo & $\mathrm{F}$ & 59 & Vivi & São Paulo & $\mathrm{F}$ & 56 \\
\hline Ni, NB & São Paulo & $\mathrm{M}$ & 52 & Ya & São Paulo & $\mathrm{M}$ & 61 \\
\hline Pal & São Paulo & $\mathrm{F}$ & 63 & Yn & São Paulo & $\mathrm{M}$ & 64 \\
\hline Pea & São Paulo & $\mathrm{M}$ & 54 & Yo, YF & São Paulo & $\mathrm{F}$ & 56 \\
\hline
\end{tabular}


ANEXO B - Exemplos de protocolos

(Registro manual) Criança

Data ....15.08.01.

Instituição .Honor

\begin{tabular}{|c|c|c|c|c|c|}
\hline $1^{\mathrm{O}} \cdot \mathrm{min}$ & $\begin{array}{l}\text { Descrição do comportamento } \\
\text { Mi diz a Ja-É de mentirinha! } \\
\text { Ale - Eu era nenê. (Engatinha) } \\
\text { Mi - Dá a mãozinha. } \\
\text { Ale - Eu era bebê. } \\
\text { Ja se senta. }\end{array}$ & $\begin{array}{l}\text { Materi- } \\
\text { al/local } \\
\text { Campo }\end{array}$ & $\begin{array}{l}\text { Partici- } \\
\text { pantes } \\
\text { Ja, Ale }\end{array}$ & $\begin{array}{l}\text { Tipo in- } \\
\text { teração } \\
\text { Cooper. }\end{array}$ & $\begin{array}{l}\text { Tipo par } \\
\text { ticipação } \\
\text { Faz-de- } \\
\text { conta }\end{array}$ \\
\hline $2^{\circ} \cdot \min$ & $\begin{array}{l}\text { Mi diz às companheiras, que estão fazendo } \\
\text { bolo de grama: Este bolo é meu. } \\
\text { - Vou ao banheiro. (vai até a árvore e, } \\
\text { embaixo dela, finge lavar-se com muito } \\
\text { detalhe, percorrendo com sabão todas as partes } \\
\text { do corpo). } \\
\text { Ale vai até ela e volta. } \\
\text { Mi continua simulando seu banho, fecha a } \\
\text { torneira. Finge vestir-se e puxar o zíper da } \\
\text { calça. }\end{array}$ & Idem & Idem & Idem & Idem \\
\hline $3^{\mathrm{O}} \cdot \min$ & $\begin{array}{l}\text { Simula pentear-se , dá os retoques finais e } \\
\text { volta ao grupo. } \\
\text { A Ja - O que você quer que eu compre? } \\
\text { Capim? } \\
\text { Já - Capim, não. Compra outra coisa. } \\
\text { Mi - O que? Leite? }\end{array}$ & Idem & Idem & Idem & Idem \\
\hline $4^{\mathrm{O}} \cdot \min$ & $\begin{array}{l}\text { Ja - Compra doce de leite, chocolate, bolinho } \\
\text { pro lanche. } \\
\text { Mi - Tchau! } \\
\text { Ja e Ale brigam pelo lugar para sentar. } \\
\text { Ale a Mi - Compra aqueles biscoitinhos. } \\
\text { Mi vai sozinha à "mercearia" (banco de } \\
\text { madeira), simula conversar com a atendente. }\end{array}$ & Idem & Idem & Idem & Idem \\
\hline $5^{\circ} \min$ & $\begin{array}{l}\text { Finge fazer as compras. } \\
\text { Mostra sacola imaginária a Ja: Só isso você } \\
\text { mandou comprar? } \\
\text { Mi volta ao banco de madeira e finge comprar } \\
\text { mais. } \\
\text { Grita de lá para Ja: Ca(r)pim já tem lá em } \\
\text { casa? }\end{array}$ & Idem & Idem & Idem & Idem \\
\hline
\end{tabular}




\begin{tabular}{|c|c|c|c|c|c|}
\hline $\begin{array}{l}1^{O} . \min \\
12.43\end{array}$ & $\begin{array}{l}\text { Descrição do comportamento } \\
\text { Corre pela varanda com os colegas numa } \\
\text { brincadeira de pega-pega. } \\
\text { Num dado momento, ainda na varanda, } \\
\text { conversa com alguém dentro da sala de aula. }\end{array}$ & $\begin{array}{l}\text { Materi- } \\
\text { al/local } \\
\text { varanda }\end{array}$ & $\begin{array}{l}\begin{array}{l}\text { Partici- } \\
\text { pantes }\end{array} \\
\text { Mais de } \\
\text { quatro, } \\
\text { ambos } \\
\text { os sexos }\end{array}$ & $\begin{array}{l}\text { Tipo in- } \\
\text { teração } \\
\text { Interat. }\end{array}$ & $\begin{array}{l}\text { Tipo par } \\
\text { ticipação } \\
\text { Turbulen- } \\
\text { ta distal, }\end{array}$ \\
\hline $2^{\circ} . \min$ & $\begin{array}{l}\text { Corre pelo pátio aparentemente procurando os } \\
\text { colegas. } \\
\text { Encontra Ta. Ambas espreitam os colegas, } \\
\text { escondendo-se atrás da parede do prédio. } \\
\text { Mi corre, distanciando-se da varanda. } \\
\text { Volta correndo, encontra And, que a pega pela } \\
\text { blusa. } \\
\text { Ambas correm pelo pátio. And pega-a } \\
\text { novamente e a solta. } \\
\text { Mi pega Yn. } \\
\text { Yn a provoca: você não me pega! }\end{array}$ & $\begin{array}{l}\text { Pátio } \\
\text { trás }\end{array}$ & Yn & Idem & Idem \\
\hline $3^{O} \cdot \min$ & $\begin{array}{l}\text { Mi e os colegas continuam correndo na } \\
\text { brincadeira de pega-pega }\end{array}$ & Idem & $\begin{array}{l}\text { Mais de } \\
\text { quatro, } \\
\text { ambos } \\
\text { os sexos }\end{array}$ & Idem & Idem \\
\hline $4^{\mathrm{O}} \cdot \min$ & $\begin{array}{l}\text { Junto com os colegas, na porta do banheiro, } \\
\text { provocam algum companheiro que está dentro } \\
\text { do banheiro. } \\
\text { As meninas riem e saem correndo. Depois } \\
\text { voltam para a porta do banheiro. } \\
\text { Mi corre atrás de Ig, que saiu do banheiro. } \\
\text { Senta-se no chão e brinca com uma folha seca. } \\
\text { Grita alguma coisa chamando os colegas }\end{array}$ & $\begin{array}{l}\text { Varanda } \\
\text { e pátio } \\
\text { trás }\end{array}$ & $\begin{array}{l}\text { Mais de } \\
\text { quatro, } \\
\text { ambos } \\
\text { os sexos }\end{array}$ & Idem & $\begin{array}{l}\text { Provoc. }+ \\
\text { BT distal }\end{array}$ \\
\hline $5^{\circ} \mathrm{min}$ & $\begin{array}{l}\text { Aproxima-se do grupo e pega Ig novamente. } \\
\text { Junto com Ig, foge de Fran. } \\
\text { Pula num buraco de areia e diz: olha aqui! } \\
\text { Anda pelo pátio atrás de um ou outro grupo, } \\
\text { depois senta-se. } \\
\text { Tam se aproxima dela ambas observam o } \\
\text { grupo. Ga conversa com ela. } \\
\text { Observa o grupo enquanto conversa com Fran } \\
\text { que está sentada ao seu lado. }\end{array}$ & $\begin{array}{l}\text { Pátio } \\
\text { trás }\end{array}$ & $\begin{array}{l}\text { Ga } \\
\text { Fran }\end{array}$ & Inter. & $\begin{array}{l}\text { Conver- } \\
\text { sa/ } \\
\text { observa }\end{array}$ \\
\hline
\end{tabular}

